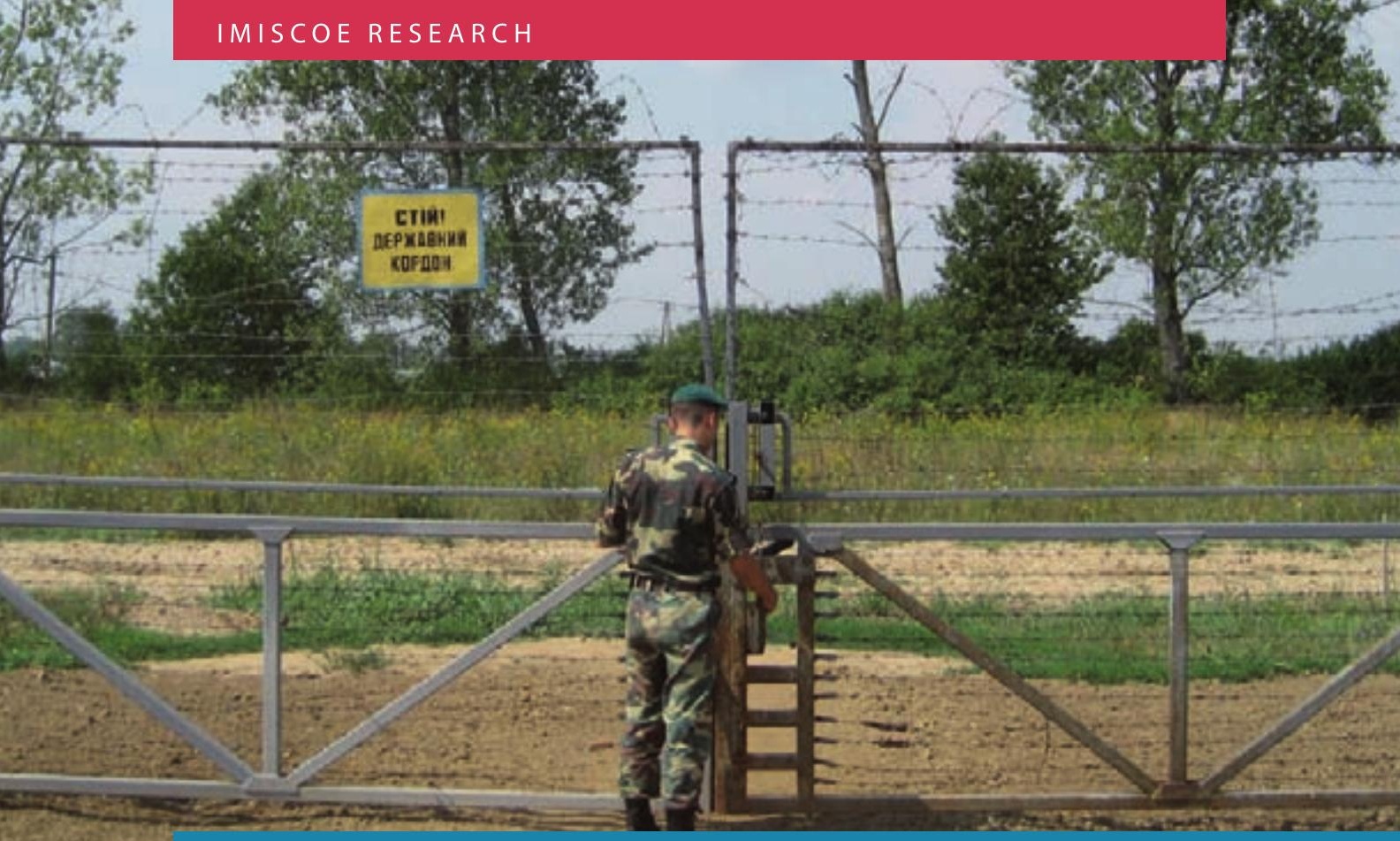

Edited by Franck Düvell, Irina Molodikova \& Michael Collyer

\title{
Transit Migration in Europe
}

Amsterdam 

Transit Migration in Europe 


\section{IMISCOE \\ International Migration, Integration and Social Cohesion in Europe}

The IMISCOE Research Network unites researchers from some 30 institutes specialising in studies of international migration, integration and social cohesion in Europe. What began in 2004 as a Network of Excellence sponsored by the Sixth Framework Programme of the European Commission became, as of April 2009, an independent self-funding endeavour. IMISCOE promotes integrated, multidisciplinary and globally comparative research led by scholars from various branches of the economic and social sciences, the humanities and law. The network furthers existing studies and pioneers new scholarship on migration and migrant integration. Encouraging innovative lines of inquiry key to European policymaking and governance is also a priority.

The IMISCOE-Amsterdam University Press Series makes the network's findings and results available to researchers, policymakers and practitioners, the media and other interested stakeholders. High-quality manuscripts are evaluated by external peer reviews and the IMISCOE Editorial Committee. The committee comprises the following members:

Tiziana Caponio, Department of Political Studies, University of Turin / Forum for International and European Research on Immigration (FIERI), Turin, Italy

Michael Collyer, Sussex Centre for Migration Research (SCMR), University of Sussex, United Kingdom

Rosita Fibbi, Swiss Forum for Migration and Population Studies (SFM), University of Neuchâtel, Switzerland / Institute of Social Sciences, University of Lausanne

Agata Górny, Centre of Migration Research (CMR) / Faculty of Economic Sciences, University of Warsaw, Poland

Albert Kraler, International Centre for Migration Policy Development (ICMPD), Vienna, Austria

Jean-Michel Lafleur, Center for Ethnic and Migration Studies (CEDEM), University of Liège, Belgium

Jorge Malheiros, Centre of Geographical Studies (CEG), University of Lisbon, Portugal

Eva Østergaard-Nielsen, Department of Political Science, Autonomous University of Barcelona, Spain

Marlou Schrover, Institute for History, Leiden University, The Netherlands

Patrick Simon, National Demographic Institute (INED), Paris, France

IMISCOE Policy Briefs and more information on the network can be found at www.imiscoe.org. 


\title{
Transit Migration in Europe
}

\author{
Edited by \\ Franck Düvell, Irina Molodikova \& Michael Collyer
}

IMISCOE Research

Amsterdam University Press 
Cover illustration: Frank Düvell

Cover design: Coördesign, Leiden

Typesetting: Crius Group, Hulshout

Amsterdam University Press English-language titles are distributed in the US and Canada by the University of Chicago Press.

ISBN $\quad 9789089646491$

e-ISBN $97890485^{2} 316$ o (pdf)

e-ISBN $\quad 9789048524778$ (e-Pub)

NUR $\quad 747$

(c) Franck Düvell, Irina Molodikova \& Michael Collyer / Amsterdam University Press,

Amsterdam 2014

All rights reserved. Without limiting the rights under copyright reserved above, no part of this book may be reproduced, stored in or introduced into a retrieval system, or transmitted, in any form or by any means (electronic, mechanical, photocopying, recording or otherwise) without the written permission of both the copyright owners and the authors of the book. 


\section{Table of Contents}

Preface

1 Introduction

Transit Migrations and European Spaces

Michael Collyer, Franck Düvell, Hein de Haas \& Irina Molodikova

1.1 The value of the concept of 'transit migration' $\quad 15$

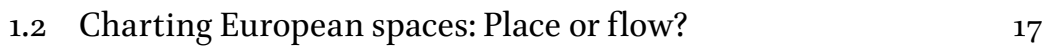

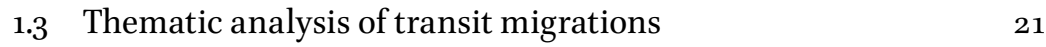

$\begin{array}{ll}1.4 & \text { Papers in this collection } \\ 28\end{array}$

\section{Part 1 The Mediterranean Quadrants}

2 Migrants' Uncertainties versus the State's Insecurities

Transit Migration in Turkey

Ahmet İçuygu \& Deniz Sert

2.1 Introduction

2.2 Transit border crossings in Turkey: Some facts 38

2.3 Environment of uncertainty $\quad 46$

2.4 Environment of insecurity 49

$\begin{array}{ll}2.5 \text { Conclusion } & 53\end{array}$

3 Refugee Migration to Egypt: Settlement or Transit? 55

Mulki Al-Sharmani

3.1 Introduction $\quad 55$

3.2 The history of refugee migration to Egypt $\quad 56$

$\begin{array}{ll}3.3 & \text { Egypt's policies on refugees }\end{array}$

3.4 UNHCR Cairo: Protection policies $\quad 64$

$\begin{array}{lll}3.5 & \text { Refugees' experiences } & 71\end{array}$

3.6 Conclusion: Settlement or transit? $\quad 75$

4 Transnational Migration $\quad 79$

The Case of Sub-Saharan Transmigrants Stopping Over in Morocco

Mehdi Alioua

4.1 The stage: The best place to observe and understand

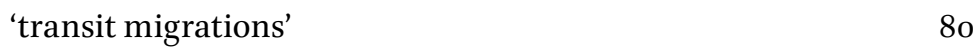

4.2 The establishment of collectives in Maghrebian stopovers 84

4.3 The impact of transmigration on local populations 91 
5 Trying to Transit

Irregular Immigration in Malta

Cetta Mainwaring

$\begin{array}{llr}5.1 & \text { Introduction } & 99\end{array}$

$\begin{array}{ll}5.2 & \text { EU migration policy } \\ & 100\end{array}$

$\begin{array}{lll}5.3 & \text { Malta } & 108\end{array}$

5.4 Trying to transit: Migrant accounts and strategies $\quad 110$

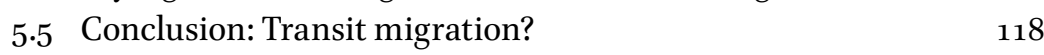

\section{Part 2 The Central and Eastern European Quadrants}

6 The East-to-West Circuit $\quad 127$

Transit Migration through Russia

Irina Ivakhnyuk

$\begin{array}{lll}6.1 & \text { Introduction } & 127\end{array}$

6.2 The emergence of Russia as a transit zone 131

6.3 Interstate cooperation in counteracting irregular
migration, human smuggling and trafficking

$\begin{array}{lr}6.4 \text { Conclusion } & 144\end{array}$

7 Hungary and the System of European Transit Migration 153 Irina Molodikova

$\begin{array}{lll}7.1 & \text { Introduction } & 153\end{array}$

7.2 Theoretical and methodological approaches to research $\quad 155$

7.3 Main types of legal migration flows in Hungary 157

7.4 Illegal migration in the Schengen zone: Old or new $\begin{array}{ll}\text { migration patterns? } & 161\end{array}$

7.5 Transformation of migration flows after Schengen extension 170

7.6 Adaptation strategies of refugees and protected migrants:

The results of three years' life in Hungary 175

7.7 Integration plans as officials see them: New laws and new $\begin{array}{ll}\text { opportunities } & 179\end{array}$

$\begin{array}{lll}7.8 \text { Conclusions } & 181\end{array}$

8 Irregular Transit Migration of Moldovan Citizens to the

European Union Countries $\quad 185$

Valerii Mosneaga

$\begin{array}{lll}8.1 & \text { Introduction } & 185\end{array}$

8.2 The push factors of Moldovan migration 186

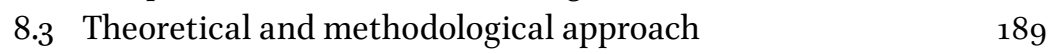


8.4 Government efforts on migration management 190

8.5 Irregular (transit) migration from Moldova 191

8.6 The services for illegal migration and trafficking 197

8.7 Main routes for transit migration from Moldova to the EU 199

8.8 Return transit migration to Moldova 202

8.9 Irregular transit migration via the Republic of Moldova 203

$\begin{array}{ll}8.10 \text { Conclusion } & 204\end{array}$

9 Transit Migrations in the European Migration Spaces 209

Politics, Determinants and Dynamics

Franck Düvell

9.1 Contrasting geopolitical structures and migration regimes 211

9.2 Causes, patterns and consequences of transit migration $\quad 215$

9.3 Characteristics and strategies of transit migrants 218

9.4 The politics of transit migration $\quad 221$

9.5 Countries transited by migrants: Similar and different $\quad 228$

$\begin{array}{ll}9.6 \text { Conclusion } & 230\end{array}$

$\begin{array}{ll}\text { Abbreviations } & 237\end{array}$

$\begin{array}{ll}\text { Author information } & 239\end{array}$

$\begin{array}{ll}\text { Other IMISCOE Research titles } & 243\end{array}$ 



\section{List of Figures and Tables}

\section{List of Figures}

Figure 1.1 Schematic illustration of the 'European space' 19

Figure 2.1 'Illegal' border crossings by season, 2006-2009 44

Figure 2.2 'Illegal' border crossings by location, 2006-2008 45

Figure 6.1 Duration of stay in Russia and migration intentions $\quad 149$

\section{List of Tables}

Table 2.1 Indicative numbers of migrants to Turkey, 1996-2008 41

Table 2.2 Apprehended irregular migration cases, 1995-2006 42

Table 5.1 Malta: Arrivals, asylum applications, recognition rates and returns, 1995-2009* 121

Table 6.1 Numbers of transit migrants (persons) 145

Table 6.2 Arrivals of foreign citizens to Russia, by country of origin and by purpose of travelling, 2009 (selected countries, persons) $\quad 146$

Table 6.3 Departures of foreign citizens from Russia, by country of origin and by purpose of travelling, 2009 (selected countries, persons)

Table 6.4 Immigration to Russia from other countries by reasons, 2009 compared to 2006

Table 6.5 Why did you choose to immigrate to Russia (percentage)? 148

Table 6.6 The plans of Chinese students after graduating from Moscow universities (percentage) 149

Table 7.1 Immigrants and those staying for more than three months in Hungary, number of persons 2009-2010 (without refugees and others with protected status)

Table 7.2 Number of migration-related apprehensions by border section including foreigners and citizens of Hungary, 2007-2008

Table 7.3 Number of border violators apprehended in Hungary by place of apprehension

Table 7.4 Asylum applications in Hungary and procedure:

Persons transferred to Hungary 
Table 7.5 Changes in the number of asylum applications by main nationality in Hungary, 2009-2010

Table 7.6 Dublin procedure: Received by Hungary from another member state by nationality of asylum seekers and sent by Hungary to another EU member state

Table 7.7 The number of return travels by country of origin, based on the Ministry of Interior of Hungary and IOM agreement for 2009-2010

Table 8.1 Remittances of Moldovan labour migrants in 1995-2008 (million US dollars)

Table 8.2 Migrants' preparation steps for a journey to the EU 196 


\section{Preface}

What began as an international conference successively became a colossal project. It took over six years from preparing the conference to subsequent publication of some of the papers, and thus far longer than planned. This is maybe not unusual, but this time the challenges were multiple and not always anticipated.

At the beginning we held the international conference '(Irregular) Transit Migration in the European Space', which was held in April 2008 in Istanbul. It was funded by the Network of Excellence on Immigration, Integration and Social Cohesion (IMISCOE), organised by the editors, as well as Hein de Haas from the International Migration Institute (IMI) at Oxford University and Ahmet Içduygu, Biriz Karacay and their team from Koç University, which also generously hosted the event.

The conference brought together researchers from all relevant regions in Europe and its neighbourhood. Twenty-six experts from the Russian, French and English speaking scientific community presented papers on the cases of Azerbaijan, Russia, Ukraine, Moldova, Hungary, Turkey, Cyprus, Egypt, Malta, Mali, Burkina Faso, Senegal, Morocco, Spain and Portugal, and on methodologies and research ethics; colleagues and PhD students from another ten countries (USA, UK, the Netherlands, Germany, Sweden, France, Italy, Turkey, Libya and Estonia) contributed to the discussion. This circled on concepts and definitions, constructions and discourses, EU and Russian migration and asylum politics, migrants' strategies and smuggling, analyses and methods. Various perspectives were taken, as from sending (Moldova, Senegal) and receiving countries (Spain, Portugal), from staging posts (Mali), 'dead end roads' (Cyprus and Malta) and 'transit countries' (Ukraine, Turkey and Morocco).

For various reasons, not all papers could be considered for publication and not all papers could be published in one volume. Also, not all countries or regions that are transited by migrants are covered in this book. This is because first, not all regions are equally well researched and there remain research gaps; second, the cases presented here are considered to be precedent cases which also throw light on the countries not explicitly covered here; and third, more case studies would inevitably produce repetitive results. Some papers were made available in a special issue of Population, Space and Place published in 2011. Others went into a Russian volume which was published by University Books, Moscow, in 2009, which contains some of the chapters presented in this volume as well as contributions that were considered less 
relevant for a Western audience. Several papers were made available online at the Centre for Migration, Policy and Society, University of Oxford, at www.compas.ox.ac.uk/events/past_conferences_events.shtml. Finally, a policy brief was published at the IMISCOE website at www.imiscoe.org/ publications/policybriefs/documents/PB12-Transitmigration-Duvell.pdf.

All chapters in this book are revised and updated versions of the conference papers. The main challenge, as it turned out, lay in the different scientific cultures of the scholars involved, the trilingual communication between editors, authors and translators and the actual translation of the chapters from Russian and French into a common language, English. All chapters were updated by additional research, they were revised several times, some had to be translated and retranslated (our thanks go to Alan Watt at the Central European University) due to quality issues, another translator had to be replaced and still some final language editing (thanks to Briony Truscott from the International Migration Institute) was necessary. All this was only made possible by a team effort and the hard work of additional translators who remained anonymous to most of the editorial consortium. Our thanks also go to some anonymous referees who compelled us to make some cumbersome but necessary revisions that improved the volume. We hope the readers appreciate these efforts and enjoy the book!

Franck Düvell, Centre on Migration, Policy and Society, Oxford Irina Molodikova, Central European University, Budapest Michael Collyer, Sussex University, Brighton

Oxford, October 2013 


\title{
$1 \quad$ Introduction
}

\author{
Transit Migrations and European Spaces
}

\author{
Michael Collyer, Franck Düvell, Hein de Haas \& Irina \\ Molodikova
}

The term 'transit migration' has a long history dating back to the movement of refugees out of German occupied Europe during the Second World War and covering immediate post-colonial arrivals of migrants in important gateway cities, such as Marseille (Temime 1989), but the use to which we refer may be traced to its appearance in policy documents from the early 1990s onwards to refer to largely irregular migration into the European Union (EU), initially across the EU's Eastern external border (Wallace, Chmouliar \& Sidorenko 1996). It is now used, almost exclusively in a European context, to refer to actual or potential irregular migration in the broader vicinity of Europe, to the east, south-east and south (Düvell 2006). Despite two decades of increasingly widespread use and growing signs that notions of 'transit migration' are filtering into more academic treatments of migration with relatively little critical analysis (Papadopoulou-Kourkoula 2008), there is no substantial comparative empirical work which examines the use and usefulness of the term in the variety of contexts in which it is used: Central and Eastern Europe, the Mediterranean and North Africa. This book aims to fill that gap.

This book provides empirical evidence in support of arguments that the conceptualisation of what is called 'transit migration' is not currently sufficiently cohesive to provide a useful analytical category. This has been argued elsewhere, including in work we have completed ourselves (Collyer, Düvell \& De Haas 2010), but has not previously received such broad based empirical support. As it is widely applied, the term refers both to individuals who have already migrated and individuals who are believed to be likely to migrate but have not yet done so. 'Transit migrant' may be used to refer to individuals who have arrived in Europe. Although the ambiguity of its usage is such that it is not possible to be certain that it has never been used in this way, we know of no clear evidence of an intention to use the term specifically to refer to individuals on EU territory; in any case, once individuals have reached Europe, their means of entry becomes legally irrelevant. In the operation of the Dublin Regulation, for example, it is only the country of entry, not the means of entry, which is considered. We also 
know that the majority of irregular resident migrants in the EU entered legally, mostly on a visa, and subsequently took up employment in breach of visa regulations or failed to depart and overstayed.

The term is more commonly used to refer to individuals in any of the countries bordering Europe or indeed several more distant countries. It therefore assumes an intentionality to migrate to Europe. For individuals who are actually engaged in the migration process, such intentions are clear, but the label is not limited to those whose intentions can be read in their behaviour. There is a wider assumption that irregular migrants from elsewhere in the world who are resident in the countries surrounding Europe are also engaged in attempts to reach Europe. In countries with substantial legally and irregular resident migrant populations, such as previously was the case in Libya, politicians encourage the assumption that many such resident individuals also fall within the definition, since this increases their potential value to European border control agents. 'Yet migrants, even undocumented migrants, frequently deny such intentions (Collyer 2010). A definition would inevitably rest on the intentions of particular migrants, which are not only uncertain but change regularly.

An alternative to basing a definition exclusively on uncertain future intentions is only to consider transit migration to have occurred once it has been completed. Aspasia Papadopoulou-Kourkoula adopts this approach in the only existing monograph on the subject. She defines transit migration as 'the situation between emigration and settlement that is characterised by indefinite migrant stay, legal or illegal, and may or may not develop into further migration depending on a series of structural and individual factors'(Papadopoulou-Kourkoula 2008: 4). This definition has the merit of recognising that intentions may change, so that final destinations may become staging points (see Alioua, this volume) and points that were initially expected to be final destinations may simply be temporary stops while new destinations become the focus of further journeys. 'It is only a posteriori that the observer (and the migrant) knows if a particular stay was temporary or not' (Papadopoulou-Kourkoula 2008: 5).

This approach is clear from a sociological perspective and provides a neat definition, but it does not reflect the way the term is used in a policy context. Manifestly, migrants are labelled as transit migrants before they reach a presumed final destination in Europe, that is, the term is not used a posteriori. Indeed, once migrants have actually arrived in Europe their legal status

1 For instance, on a visit to Italy in August 2010 the then Libyan leader Gaddafi claimed that migration control cost Libya $€_{5}$ billion a year (Guardian 1 September 2010). 
becomes more significant than their means of entry and from the perspective of the states in which they reside they are not treated any differently to the more numerous illegally resident migrants who overstayed visas. Their status as 'transit migrants' therefore has no meaning a posteriori, in policy terms. In order to focus on the policy context of the term, which is the intention of this volume, we must accept the centrality of migrant intentions in any definition of the term, though this is unsatisfactory from a theoretical point of view.

The centrality of intentions is not the only problem in this definition: the term also covers a variety of legal statuses, including the typically complex arrangements between legal/illegal border crossings, asylum, residence and work. Moreover, the adjective 'transit' is applied not just to migrants themselves, but to the practices in which they are engaged ('transit migration') and regions where they are to be found (the ubiquitous 'regions/countries of origin and transit'). 'Transit migration' therefore appears as a confused political construction of dubious scientific value. In light of these criticisms, we are to some extent sympathetic to those who argue that the term should be abandoned entirely. However, as is apparent from the title of this book, we still see some value in its use, although only in reference to a migratory phenomenon, not to a label that can or should be assigned to individual migrants or to the countries through which they are considered to pass.

Finally, this volume is ultimately about the construction, definition and use of categories and typologies in migration research and thus includes two methodological messages. First, that political categories should not be simply accepted but scrutinised for their discursive purpose, use and power. Instead, this volume suggests that scientific typologies are to be developed from rigid comparison of individual cases along criteria of similarities and differences, and that one should accordingly cluster cases along these criteria and finally identify patterns which then warrant labelling (see Düvell and Vogel 2006). Second, the volume, by the way it is designed, implicitly promotes multi-sited research on transit and other similar forms of migration, notably research along the routes of migration and on both sides of the border, hence at exit and entry points. Indeed, only by including those in the research that have not yet or did not manage to arrive in the EU can the full reality of this type of migration become apparent.

\subsection{The value of the concept of 'transit migration'}

Despite its problems, the term 'transit migration' has lasted. While other terms have come and gone, 'transit migration' has retained some wide 
appeal in a variety of political and advocacy contexts over more than two decades. Given the impossibility of reaching a clear, workable definition that is both scientifically robust and reflects the dominant policy context of the term, we do not propose using 'transit migration' as a category of analysis in the book, but as a category of practice, ${ }^{2}$ a significant political label (Brubaker \& Cooper 2000; Zetter 2007). The flexibility and ambiguity of the term, which make it inappropriate for scientific use, make it ideally suited to the politics of migration in the European neighbourhood. In such highly charged political environments, terms which can convey a variety of meanings are particularly popular. There may be good reasons for this, such as during the initial stages of complex negotiations when securing agreement on anything is a positive step. However, there are also significant problems, particularly when these terms begin to enter wider currency. Ambiguous language may then be used not to secure initial agreement but to mask continuing disagreement.

In the case of 'transit migration' to the European Commission and EU member states it refers to the perceived need to be seen to control undocumented migration across the EU's external border; to neighbouring countries, it may initially have been imposed upon these neighbouring countries, but there are increasing signs that they are identifying elements of self interest in responding to new forms of immigration which are partially shaped by attempts to control undocumented migration; finally, for migrants' rights groups it has provided a label for a range of primarily humanitarian concerns, and for 'no borders' advocates it is a useful illustration of the harmful and self-defeating character of EU migration controls.

In all of these contexts, 'transit migration' is used as shorthand for more significant changes within global migration systems, which require more detailed attention. As it is currently used, it may gesture towards important changes in migration systems in and around Europe. Indeed, while it is important to maintain a critical position on its broader application, it may describe an amalgamation of concerns surrounding immigration into states neighbouring Europe, particularly when that immigration is not authorised by those states. This includes the easier access that migrants are thereby assumed to gain to European territory, the (related) increasing stringency of controls at the European external border, the means of onward transportation and the physical risk this poses to the migrants. The situa-

2 Brubaker and Cooper define 'categories of practice' as 'categories of everyday social experience, developed and deployed by ordinary social actors [in this case policymakers] as distinguished from the experience-distant categories used by social analysts' (2000: 4). 
tion is complicated when individual migrants wish to register a claim for protection as refugees, which requires some attempt to classify the nature of refugee movement and distinguish it from that of other migrants, a situation described by a wide variety of labels in recent years such as 'irregular secondary movement', the 'migration-asylum nexus' or 'mixed migration'. The increasingly common result is that migrants are 'stranded': unable to continue, unable or unwilling to return and often facing considerable hardships just to remain where they are.

At this stage we do not wish to focus this range of possible meanings and uses of 'transit migration' into a clear definition. This breadth of application is one of the secrets of the term's success and any attempt at more specific definitions would inevitably exclude some important ways in which the term has been used. There is no single element common to everything that has been labelled transit migration. We wish only to recognise this plurality of uses, indicated by the plural 'transit migrations' in the title of this introduction. Much the same could be said of 'European space', a second deliberately broad term that draws attention to the euro-centeredness of all considerations of 'transit migration'. The same range of migratory phenomena can be found in Central America and Mexico, in the south of Africa, across the Gulf of Aden to Yemen, from North Korea through China to South Korea, or in the vast open oceans between Sri Lanka, Indonesia, Malaysia and Australia. Yet 'transit migration' as a term is applied almost exclusively to the European space.

\subsection{Charting European spaces: Place or flow?}

'European space' is most obviously the territory of the European Union and it is important to remember that 'transit migration' is an issue within the EU, as many EU member states have historically been transit points for migrants seeking to reach other parts of Europe and indeed many continue to be so. This is apparent at the few controlled borders within the EU, such as the informal settlements in and around the town of Calais. These points typically occur at the borders between the Schengen Zone and the EU member states situated outside Schengen (such as the UK). These are likely to change, as internal Schengen border controls are periodically re-established, as they have been between Italy and France in response to concerns around migration from Libya in April 2011. Recent enlargements of this core 'European space' have incorporated further transit points, represented by the chapters on Malta and Hungary in this volume. Yet European 
space extends beyond the current external border of the EU, through the wide range of political agreements drawing surrounding countries into the European sphere of influence. We follow a hierarchical understanding of European space beyond the EU which may be imagined as a series of concentric circles (figure 1.1).

Immediately beyond EU territory sit Norway and Iceland, politically distinct, since they are not involved in the EU political institutions, but virtually an integral part of the EU from the perspective of migration through their participation in the Schengen system. Neither Norway nor Iceland are significant in terms of transit migration so we have no case studies of this section of European space. A step further from core EU space are candidates for EU membership, currently only two (Turkey and FYROM), though the EU recognises a further six 'potential' candidate countries (Albania, Bosnia and Herzegovina, Montenegro, Serbia, Kosovo and Iceland). Turkey is in a special situation due to the duration of its accession negotiations, and to the widespread opposition amongst several EU member states to its final accession. Turkey is one of the most significant areas of concern to the European Commission in terms of transit migration and so an important case study for this book.

The third and final element of European space which we examine in this book is those countries which are more unlikely to become members, yet nonetheless retain a special relationship with the EU through the European Neighbourhood Policy (ENP). This is Europe's 'circle of friends', as Romano Prodi first described them, 16 countries who will eventually share in the basic freedoms of Europe without participating in European institutions. Migration is one of the key reasons for the importance of the EU's relationship with these countries and this is reflected in the prominence of migration in all ENP action plans and country reports. ${ }^{3}$ We consider Morocco, Egypt and Moldova; Ukraine is another relevant country and looked at from the perspective of its EU neighbour, Hungary. Indeed, it falls in-between the categories. A previous president expressed an interest in EU membership, which however, is unlikely to materialise at any time in the near future. We also consider Russia, which is not included in the ENP, though it was initially invited and is therefore considered as belonging to this division of European space by the Commission. Russia rejected membership of the ENP, since the importance of Russia's bilateral relationship with the EU (for both parties) cannot be considered as comparable with that of other ENP members.

3 Action plans and country reports for all 16 countries are available on the Commission website at http://ec.europa.eu/world/enp/documents_en.htm. 
Figure 1.1 Schematic illustration of the 'European space'

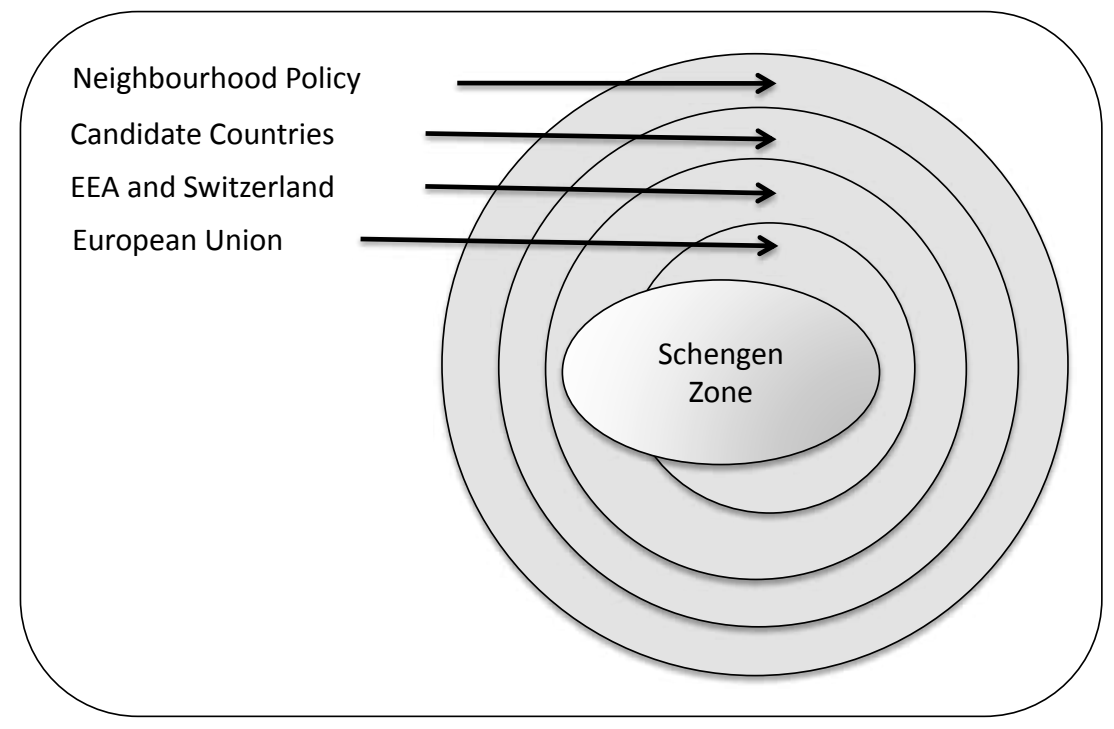

As others have recognised, this understanding of levels of European space presents a fundamentally hierarchical division of territory. This division relates to the level of access that can be gained to the core European space of the EU and the imagination of this in the pattern of concentric circles translates to political and spatial proximity to the EU core. There are other parts of the world which may arguably form part of this European space, perhaps most obviously the European space inside consulates, embassies or, increasingly, private firms where visas are delivered. These and other 'remote controls' are important stages in the encounter between a nonEuropean migrant and the European border, but they are distinct from the more directly spatial imagination of concentric zones since there is no direct access from visa delivery points to the core EU territory except through regimented channels. The reason why transit migration raises such concerns from a policy perspective is the very avoidance of these channels, and this is seen as more likely from the more immediate spatial proximity of the European Neighbourhood.

Our choice of case studies in this book is not only influenced by an interest in representing the distinct policy regimes linking each of these concentric zones to the EU but also by a desire to reflect the variety of routes taken by transit migrants. This relates to a different, more linear imagination of European space, as a 'space of flows' as much as a 'space of places' (Castells 1996), an understanding that is common to border control 
agencies. In this interpretation, European space as understood above may be divided not into concentric rings but into zonal quadrants, identifying different geographical regions from which migrants originate and the nature of the barriers they have to encounter along the way. Following observations from border control agencies and common policy conceptualisations of transit migration (e.g., ICMPD 2007) we identify four clear zones within the European space: Western Mediterranean, Central Mediterranean, Eastern Mediterranean/Middle East and Central and Eastern Europe.

The chapters which follow therefore also provide some insight into the contrasting situation in each of these zonal quadrants. With regards to Central and Eastern Europe, the chapters on Russia, Moldova and Hungary present different aspects of the policy framework and empirical context of migration in this quadrant. Turkey occupies a key position in the Eastern Mediterranean/Middle Eastern quadrant, bordering Greece and Bulgaria but also Syria, Iraq and Iran, and is in reach of Afghanistan, Eritrea and Somalia. The booming economy of Istanbul and the tourist zones of the south west of the country create the demand for migrant labour, its ports and airports are major hubs for internationally mobile populations and its proximity to some troubled parts of the world results in significant arrivals of refugees. But the rising migrant and refugee population just outside the EU's external border also provokes concerns from the EU.

In the Central Mediterranean, Libya has attracted most attention recently and has a similar mix of large-scale labour immigration, recently interpreted as an indication of significant transit migration. Nevertheless, it is important to emphasise that Libya is first and foremost a destination country for labour migrants from poorer North African and sub-Saharan African countries (Hamood 2006; Pliez 2005). Research in Libya remains extremely difficult and our case study from this region is the situation in Egypt where substantial refugee migration, besides labour migration, provides a migration connection between the conflict affected countries of Eastern and Central Africa and the Mediterranean. This is supplemented by the chapter on Malta, which, since its entry into the EU in 2004 has been seen as an important outpost in the EU's migration control system and as such has received a small but substantial number of migrants who arrive in their attempts to reach Italy or France. Finally, the Western Mediterranean quadrant describes a further distinct connection of migration systems between West and Central Africa, Algeria and Morocco, and Spain, which provides the regional case study.

Our conception of European space therefore relates to both place and flow. First, we are concerned with policy agreements and spatial proximity, 
which combine to produce an imagined hierarchy of concentric spaces around the core EU space; and second, with a dynamic understanding of migration routes crossing these areas. Just as transit migration is more correctly thought of in the plural, it is obvious that this multiplicity of spaces and routes cannot be conceptualised as any kind of single homogenous 'European space'. We are really discussing many different European spaces that are produced and maintained in relation to each other in different ways. The production of this hierarchy of spaces is paradoxically reinforced by the intensified security apparatus, which has in turn driven up the rates that may be charged by smugglers or traffickers across the EU's external border and also around this neighbourhood region. The book sets out to disentangle the many themes involved in an analysis of the wide variety of practices of movement and non-movement subsumed under the label of transit migration in this patchwork of differently imagined European spaces.

\subsection{Thematic analysis of transit migrations}

There are a number of themes which emerge from this attention to transit migrations in European spaces which the book also aims to highlight. We identify six separate migration related issues which are brought into relief by the range of relatively new developments associated with the variety of migratory phenomena that are bundled into the single term 'transit migration'. These are humanitarian, statistical, legal, geopolitical, technological and broader conceptual concerns. The significance of these themes is an important element in the justification of transit migration as a focus of this book. They relate to a diverse array of changes in migration into and within European space over the last decade or so.

The first of these, and the most pressing concern, is the humanitarian issue posed by the very high risks involved in overland and maritime journeys. Such risks are now commonly recognised in media, policy and academic treatments of migration to Europe, though information on the numbers of individuals killed or injured during the course of their migration to Europe is inevitably tremendously uncertain. Those bodies washed ashore, found in the desert or mountains are grim testament to the number of individuals dying at sea by drowning, in the desert from dehydration or in the mountains from hypothermia. As journeys become increasingly lengthy and require much greater navigational skill, such as the passage from West Africa to the Canary Islands, or Libya to Lampedusa, death from 
other causes, such as exposure or starvation, is common. Many bodies are never discovered, swept out to sea or buried by sand dunes leaving no trace. Statistics compiled by United against Racism (2013) provide evidence of more than 17,306 migrants who lost their lives in the decade 1993-2013 as a direct or indirect consequence of migration politics; almost 80 per cent of those lost their lives whilst attempting to reach Europe. These numbers seem to be increasing, though it is not clear if this is due to greater awareness and so wider reporting or if fatalities have actually increased. These estimates are shocking, but are likely to be short of the mark given that in the absence of bodies, which is the case in so many maritime incidents, it is very difficult to document the number of deaths. If we also consider those who die during a crossing of the Sahara, where information is similarly limited, the hazards of these high risk migrations to Europe may even be higher.

This uncertainty of basic data leads to our second theme of statistics. Few countries in the world collect perfect migration data, but within the EU social scientists have come to rely on officially produced migration statistics as a reasonably close approximation of reality. Notably in the field of irregular migration, FRONTEX, the 'European Agency for the Management of Operational Cooperation at the External Borders of the Member States of the European Union', now almost holds a monopoly on data on irregular border crossings and thus considerable discursive power and it has become highly complicated, if possible at all, to control such data. In most cases, despite their flaws, official statistics are used as if they were reality, receive broad consensus and are generally adequate to detect trends and fluctuations in migration. This is very different in the case of transit migrations, where no information receives such consensus. This obviously arises from the lack of basic agreement on exactly who is a transit migrant. Not only is there no consensus on basic definitions but there is no data available on any of the possible alternative meanings: individuals illegally resident in Europe; illegally resident individuals who also entered Europe illegally; illegally resident individuals in countries surrounding Europe; illegally resident individuals outside Europe who also eventually intend to reach Europe, legally or illegally; individuals beyond the immediate fringes of Europe. The centrality of intentions to understandings of transit migration means that it is not only practically very difficult to be certain of statistics (as with undocumented migration more generally) but theoretically impossible.

The only data which are certain and verifiable are the number of apprehensions of migrants, but the relationship of this number to the unknown number of migrants who evade controls is so uncertain that a fall and 
a rise in apprehensions can both be interpreted as a sign of successful border control operations or a fall or rise in actual migration flows (Collyer 2008; De Haas 2007). And because migrants try to cross borders more than once in the case they are apprehended they are sometimes counted repeatedly, hence the number of apprehensions is higher than the number of individuals apprehended (Düvell \& Vollmer 2009). The understanding of transit migrations as encompassing migrants who are actively engaged in attempts to reach Europe and those who may well be content to stay where they are adds to the difficulty of estimating numbers. This fact means that estimates of the number of migrants attempting to reach Europe can be easily manipulated, a fact we consider in more detail under the theme of geopolitics below. Evidence from surveys with undocumented migrants in Spain and Italy suggests that only a small minority of them ( 5 to 10 per cent) reached Europe in a clandestine manner. ${ }^{4}$ The vast majority arrived with legitimately obtained visas and overstayed. This suggests that the significant media and policy attention devoted to transit migrations outweighs their numerical significance from an EU perspective. This is important to bear in mind. Indeed our argument for the significance of transit migration does not depend on its numerical significance, but on the challenges it poses to a range of accepted principles of studying migration, in this case, reliance on data.

A further challenge posed by transit migrations and the third theme we consider here is the legal context. Legal status is significantly more varied than more easily classified forms of movement. Concern about the human cost of transit migration is expressed by the European Commission and member state governments, by governments of neighbouring countries, by international organisations, such as the International Organization for Migration (IOM) or the United Nations High Commissioner for Refugees (UNHCR) and most forcefully by migrants' rights and community organisations. What differs across this range of interest groups is the explanation given for the high incidence of migrant fatalities and with it the possible legal remedies to reduce the risks of migration. For many civil society groups it is migration legislation itself which is at the root of the regular tragic

4 The Spanish Police Union (Sindicato Unificato de Policia) reported that only 5 per cent of undocumented migrants to Spain arrived by boat in 2006, compared to 80 per cent who arrived at Madrid or Barcelona airports (El Pais 4 January 2007). Similarly, according to Italian police data only 10 per cent of undocumented migrants in Italy had entered the country by sea (cited in Cuttitta 2005). The survey of 2,200 migrants from Morocco or Senegal to Spain and Egypt or Ghana to Italy by the Netherlands Interdisciplinary Demographic Institute (NIDI) found that, of those who reported illegal residence, $5^{8}$ per cent had overstayed visas (Schoorl et al. 20oo). 
incidents at the land and sea borders of Europe. According to this argument, the displacement effect of increasingly strict controls on air travellers, since the late 1980s, initiated the rise in overland migrations. As border controls on the shorter routes, such as across the Straits of Gibraltar, have intensified, migrants put themselves in greater danger to avoid them, for example through the gradual migration of departure points down the North West coast of Africa from Tangier to Dakar and eastward to the Algerian, Tunisian and Libyan coastlines. In a limited number of cases border control officials have actually been directly responsible for migrant deaths. This was the case in September 2005 at the borders of Ceuta and Melilla, when 16 migrants died. On the Eastern European land borders, however, very few deaths are reported and increased border controls have not resulted in fatalities. Another issue that raises concerns of humanitarian organisations is the treatment of the apprehended migrants, notably detention conditions, which in Libya, Turkey and Ukraine are reported to be often inhumane.

The argument that border control causes migrant deaths is rejected by the European Commission and member states who point, rather, to the development of smuggling and trafficking operations as the main culprit; indeed members of the European border control organisation, FRONTEX, cite incidents where border control officials have actually saved migrants stranded at sea. The policy priority is therefore to stamp out migrant smuggling and trafficking operations and to develop partnerships with neighbouring states to facilitate this. This polarisation of explanations with governments on the one side and civil society on the other is slightly over-simplified and there are plenty of examples when the complexity of the issues is acknowledged by both sides. The European Commission and Parliament, in particular, have been quick to acknowledge incidents when border control officials appear to have been responsible for migrant deaths, such as Ceuta and Melilla in 2005. The EU also accepts some criticism of the detention facilities in certain neighbouring countries and through various programmes invests in improving these, as in Ukraine. Nevertheless the debate is taking place between questions of security and sovereign control over borders and migrants' rights and protection needs on the other. In this debate, international organisations have tried to identify actions involving a compromise between respecting state sovereignty and supporting migrants' welfare. IOM's 'Stranded Migrant Facility' is one example of this more pragmatic approach. It was established in 2005 to return migrants who applied and who were unable to either continue or return unassisted and particularly operates in countries around Europe. UNHCR's emphasis on 'protection sensitive borders' is another approach which recognises that 
border controls and detention are an integral part of the state system, but attempts to prevent individuals with a claim to protection being completely shut out by the difficulty of even reaching EU territory.

In addition to legal aspects of migration control, a further trend that we may associate with transit migrations is the development of new technologies, the fourth theme we wish to consider. These technologies encompass both border control technologies and the technology employed by migrants in order to evade border controls and navigate in hostile environments. Some research has focused on the historic antecedents for modern movements in trans-Saharan trade routes or (pre-) Soviet migration patterns (Bensaad 2005). These examples are useful to focus attention on key elements of the landscape which may be favourable to migration, such as oases or easily negotiated valleys, but beyond these the context has changed radically from the pre-state organisation of territory into spheres of influence of shifting empires.

Borders themselves are of course one element of change, ${ }^{5}$ but even where physical borders have much longer histories, the application of technology in their control has expanded considerably over the last decade (CCTV, motion sensors, radar and thermal imaging, unmanned patrol vehicles and satellites are also deployed). Negotiating these borders, as migrants from sub-Saharan Africa or Central Asia must do if they are to get close to European space, can be a difficult process. In some cases borders are reinforced by natural hazards, such as a trans-Sahara journey. Other land borders are easier to cross, as between Ukraine and Hungary; there the main issue is not any natural obstacles though occasionally people get lost in the forests and mountains. The main obstacles are first, intelligence, as conducted by the secret service; second, internal controls along the routes towards the border region; and third, border guard patrols and technology-based policing on the borders. This represents an echelon of controls combining intelligence and enforcement as well as a combination of physical and technical and remote controls. Therefore, most migrants in the Eastern quadrant require the service of smugglers from the day they arrive in Europe, for instance in Moscow, in order to navigate these obstacles.

5 Thanks to an anonymous reviewer for highlighting this point. This varies from some areas of North Africa where borders have arisen relatively recently (as in the case of the border between Western Sahara and Mauritania, gradually imposed from the mid-1970s) to fixed borders which have seen dramatic strategic changes over a similar period, such as the borders between Hungary or Slovakia and Ukraine following the collapse of the USSR and then the accession of the former Sovjet bloc countries to the EU. 
Since the late 1990s some of this has begun to change. While having much deeper historical roots in the trans-Saharan trade, migration of nomads, traders and refugees to Mauritania, Algeria and Libya since the 1970 s set the stage for contemporary trans-Saharan migration. Against the background of economic decline and warfare in West and Central Africa, Libya's new 'pan-African' immigration contributed to a major increase in trans-Saharan labour migration over the 1990s. Since 2000, a major antiimmigrant backlash in Libya has contributed to a diversification of transSaharan migration routes and the increasing presence of migrants in other Maghreb countries (De Haas 2007). Confronted with a persistent demand for irregular migrant labour in Europe, more and more sub-Saharan, mostly West African, migrants started to cross the Mediterranean. Illegal crossings of the Mediterranean by North Africans have been a persistent phenomenon since Italy and Spain introduced visa requirements in the early 1990s. The major change has been that, since 2000, sub-Saharan Africans have started to join North Africans (De Haas 2007).

In addition, technological changes and infrastructure development have encouraged migration along new routes. Handheld GPS devices are now no more expensive than a mobile phone, mobile phones can be used to communicate during the entire crossing of the Sahara, as signals are more widely transmitted and desert towns such as Tamanrasset in Algeria now have facilities to receive instant financial transfers, so migrants with family in Europe, or even support in their country of origin, can receive resources for onward movement. This implies that an increasing number of people now aspire and are also able to make the trans-Saharan journey, if they have access to only a few hundred Euros. Although various other costs along the journey may inflate this considerably, it remains well below the tens of thousands of Euros required for direct smuggling to Europe and makes these migrations attractive to those who wish to try to get work in North Africa and may have no ambition to move on to Europe. The development of increasingly rigid migration controls is therefore only one factor provoking the instigation of these migrations. Navigating the eastern borders instead mostly requires communication equipment; smugglers require informants, mobile phones and handheld radios to obtain information on the physical and technical obstacles so that these can be circumvented.

The fifth theme highlighted by transit migrations is the new geopolitical significance of migration. The relationship between the European Union and neighbouring states has always been important, but, with very few exceptions (such as Russia), the relationship has always been much more important for the neighbouring states than for the EU. For example, in 2008 
63 per cent of Morocco's exports went to the EU but only 1 per cent of the EU's exports went to Morocco (EC 2009). This imbalance creates a strongly asymmetric relationship as most neighbouring states are far more economically dependent on the EU than the EU is on them. The development of transit migrations through these countries to the EU, however, has provided many neighbouring states with valuable bargaining power in their relations with the EU. States such as Morocco and Algeria for instance, located on overland routes from West Africa to Europe, have so far resisted growing pressure from the EU to sign new readmission agreements.

These countries already accept the return of their own nationals found to be residing illegally in any EU member state, but they are now being asked to accept the return of individuals from other countries who are believed to have migrated through Morocco or Algeria. Such an agreement would manifestly not be in the interests of either Morocco or Algeria but blanket deportations to either country would be attractive for several EU member states, particularly for the Spanish and French governments. The European Commission, which is now responsible for negotiating such readmission agreements, is very keen to conclude negotiations, but although EU budgets for training of border control officials and other migration managementrelated technologies in Morocco, for example, have increased substantially, they have not yet been able to put together a sufficiently persuasive package. Libya has been even more successful at transforming its strategic location into resources from Europe. The widely quoted claim of the Libyan government that there were two million sub-Saharan Africans in Libya 'waiting' to come to Europe was widely seen as an exaggeration. There has always been a substantial immigrant population in Libya and this claim simply reclassified all of them into a 'transit migration' category. Yet, though the claim was largely fictitious, the Italian government has nevertheless made very considerable investment in Libya, in terms of detention centre infrastructure, training and equipment.

With Ukraine, however, such a readmission came into force in 2010 and after a two-year transition period during which only Ukrainian nationals were returned. The concessions made to Ukraine are (a) to assist the country in introducing a migration management system including detention centres and (b) to liberalise the visa regime for Ukrainian citizens; so far, the latter has not materialised and numbers of non-national returnees are low. Hence, Ukraine has used this agreement to modernise its migration control system, which is in the interest of the country without accepting larger numbers of returnees from the EU. Turkey, situated on the main route from some troubled regions in the Middle East and East Africa, is also lobbied by the EU 
and in particular by Greece to accept readmission of irregular immigrants of various nationalities who have entered the EU from Turkey. But by 2013 still no such policy had been implemented and since Turkey's membership application has been put on hold for so long, one might wonder why the government should comply with EU wishes.

These themes all combine into our sixth and final consideration, the conceptual significance of transit migrations. Migration has always been considered as a relatively simple transfer from a country of origin to a country of destination, though this has never been considered unproblematic from the migrants' perspective. To some extent this was a reasonably accurate portrayal of migrant experiences of the immediate post-Second World War generation, when travel was becoming quicker and less expensive and their concerns were focused on what would happen when they arrived. Contemporary migration theory is rooted in this period, from approximately 1945 to 1975, though the migration experience of these decades is actually particularly unrepresentative of migration patterns before and after this time. When journeys were longer and more convoluted there was always the possibility that something could happen along the way to force a change of plans. For the loose range of experiences subsumed under the transit migration label, that experience of travel is again the case. Even those migrants who have a destination in mind when they leave may never get there and our own research suggests that this is probably not even a majority of migrants. In this sense, we see a linear logic is something that is imposed from the outside rather than something which reflects the experience of migrants themselves. The creation of 'transit migration' is a symptom of this trend, following the logic that since every migration has a pre-defined beginning and end, anything that falls in between is simply 'transit'. The experiences of migrants on these journeys belie this simple characterisation and suggest that we should pay much greater attention to the journey itself, to the responses to their the experiences in the various countries in which people spent some time and the dynamic decision-making processes of people once they have left their country of origin. The papers collected in this book set out to do just that.

\subsection{Papers in this collection}

In the following chapter, Ahmet İçduygu and Deniz Sert consider transit migration in Turkey. The chapter considers many years of relevant fieldwork and access to unpublished border control statistics. These provide a detailed 
picture of the evolving nature of migration to and through what is, from the perspective of the EU, one of the most strategically significant migration crossroads anywhere in the world. Following this detailed statistical presentation İçduygu considers this migration from two important perspectives. First, they examine the migrants' perspective, characterising Turkey as an 'environment of uncertainty' when faced with border control agents of various countries and traffickers and smugglers. They then turn to consider migration from the perspective of the Turkish state, characterised as an 'environment of insecurity', looking at the range of readmission agreements signed by Turkey as a way of using international relations to resolve these problems of insecurity. They conclude by arguing that both perspectives are necessary if we are to understand the nature of this highly politically charged migration.

In chapter 3, Mulki Al-Sharmani examines migration trends to and from Egypt by Sudanese, Somali, Iraqi and other refugees. Although constituting a large segment of long-term migrants in Egypt, many refugees are deprived of basic resources that would enable them to establish stable and settled communities. This chapter questions the assumption that most of these refugees are transit migrants on their way to the West and therefore only to be considered as temporary. Al-Sharmani argues that a considerable number of these refugees have lived in Egypt for a decade or more and that only few of them actually resettle in the West. The analysis exemplifies the complexity of their multiple and subsequent movements which defy simple notions of them being 'in transit'. Some Somali and Sudanese refugees first migrated to other countries in Africa and the Middle East before moving to Egypt. Many Somali émigrés in Egypt were refugees in the Middle East and Africa, and resettled in the West, where they often obtained citizenship. Over the past decade, these North American and European Somalis have been increasingly relocating to Egypt, thus their movement to Egypt even turns out to be circular. Al-Sharmani argues that this highlights that the term 'transit migrant' fails to capture important aspects of migratory experiences of refugees in Egypt.

Mehdi Alioua, in chapter 4, provides a geographically influenced analysis of the situation in Morocco, since the generalisation of the visa regime across the Schengen area in the 1990s, followed by the restrictions on issuing visas, established a barrier for many Africans wishing to migrate directly to Europe. He identifies staged transnational migration, which he refers to as 'transmigration', as one solution to avoid these new difficulties. Staged migration involves opening or reopening new migratory routes from sub-Saharan Africa, through the Maghreb, to Europe. These new 
stopovers in the Maghreb have continued to serve as migratory staging posts for newcomers and they have a social history which has gradually become a part of migratory trajectories. Alioua's study of the sub-Saharan transmigrants' transnational networks therefore asks how we should see the creation of unrestricted spatial configurations produced by these moving populations, but situates this within a geopolitical context where the borders are not as porous as the term 'transnational' would suggest. In response to this, the notion of a stopover, seen simultaneously as an observation location, a methodological framework and an analytical tool, seems much more relevant than the notion of 'transit migration', which is too restrictive from the space-time point of view. In his chapter, Alioua develops and illustrates this idea, working from the example of Moroccan stopovers in the transmigration of sub-Saharan Africans.

In chapter 5 , Cetta Mainwaring examines migration and migration policy in Malta and its new role as an island in the middle of a transit zone of migration. Having joined the EU in 2004 and having seen an increase in 'boat people' arriving on the island since 2002, Malta has become an EU watch tower, a state that now has the power to act as a barrier to the mixed migration flows traversing the Mediterranean Sea. In this context, this chapter examines the changing policies and politics of migration in Malta, since joining the EU. It focuses on the relationship between Malta and the EU and how this has influenced policies on the island, as well as the relationship between Malta and Libya, another transit point for migrants in the Southern Mediterranean. We turn then to look at the implications of these changes for the mixed flows of irregular migrants arriving in Malta, especially the new strategies they must pursue in order to overcome the impediments to mobility created by EU and Maltese policies. The chapter concludes in looking at public and media discourses.

Irina Ivakhnyuk, in chapter 6, deals with migration patterns that have emerged after the collapse of the USSR. Notably Russia is found to play an important role in the journeys of migrants and refugees. The chapter also focuses on some major changes around the turn of the millennium. First and foremost, Russia is a major destination country that is an equally important destination country as the EU. But whilst some features attract and facilitate migration to the country, others facilitate on-migration. Ivakhnyuk demonstrates that what is understood as 'transit migration' is indeed intimately linked with other forms of migration, such as student mobility, as well as labour migration. Chinese migration is used as a case study. Second, the chapter analyses governance of migration in Russia and the wider Eurasian space and its consequences for migration processes. 
Indeed, international migration in Eurasia is less regulated than the Central and Western European space and the boundaries between the two spaces. Indeed, the borders of Russia are characterised as 'asymmetric', referring to relatively liberal arrangements in terms of entry from the South and East but relatively strict regimes in terms of exit to the West. Therefore, as the chapter suggests, smuggling networks are important institutions that facilitate on-migration to the West.

In chapter 7, Irina Molodikova concentrates on one of the new member states of the EU, Hungary and its non-EU neighbours to the East and South, notably Ukraine and Serbia. When the socialist system collapsed Hungary introduced liberal entry policies; as a consequence it attracted immigrants from the former Soviet neighbourhood, but began to also play the role of a transit corridor from East to the West. Even though Hungary adapted to the legal norms of the EU and subsequently became member of the Schengen space of migration control, its special relations with countries that host Hungarian minorities seem to undermine these otherwise strict regimes and facilitate irregular (transit) migration from more distant countries to Hungary as well as other EU countries. This chapter analyses migrants' journeys across the various borders of Hungary, life in refugee centres and migrants' migration strategies. It uses statistical data and interviews with different actors in the migration field: smugglers, migrants, refugees, human rights experts, police and politicians, and thus highlight the peculiarities of transit migration.

In chapter 8, Valerii Mosneaga takes the perspective of a small and poor agricultural sending country and addresses the issues of migration of Moldovan citizens. Indeed, up to a third of its working-age population is working abroad, often in an irregular situation. The major destinations, however, are not their neighbouring but various more distant countries in the Russian Federation and the European Union. Due to travel, immigration and employment restrictions, these cannot always be easily and legally reached. Therefore, Moldovan citizens frequently travel through other countries in order to get to their final destination. Often, as this empirically rich article illustrates, migration is irregular and facilitated by agencies and more or less unlawful services. Occasionally, Moldova too is transited by refugees and migrants aiming to get to another country. This chapter will mostly concentrate on transit migration of Moldovan and other citizens on their way to the EU. It is based on various qualitative and quantitative research projects, which contribute to the better understanding of the phenomenon of irregular transitional migration in its institutional and human dimensions. 
Finally, in chapter 9, Franck Düvell summarises as well as contextualises the findings presented in these case studies. He returns to some of the themes raised in this introduction. The chapter examines the implications of transit migration for both the control and the study of migration. It argues that transit migration increases the geopolitical significance of the EU's relations with its immediate neighbours, that it poses new control and protection challenges and it questions established migration categories. Nevertheless, suggestions are made to preserve the category of transit migration but simultaneously fine-tune and apply it more rigidly.

The papers collected in this book make an important contribution to disentangling the range of issues that are brought together by the term 'transit migration'. At the moment the relationship between, for example, the statistical claims made by states such as Libya about the number of migrants attempting to reach Europe and the geopolitical significance of undocumented migration in the Euro-Mediterranean region are extremely difficult to separate. Similarly, the contribution of increasingly rigid migration controls at the European border and the greater ease of movement beyond those borders facilitated by access to cheaper technologies have not been clearly distinguished in previous treatments of these issues. In this introductory chapter, we have tried to show how these themes challenge preconceptions about migration in European space and how, in the absence of greater clarity, we find it useful to think in terms of 'transit migrations', at least for the moment. The overviews of each of the papers in this final section demonstrate how the new empirical research which they present may start to clarify the relationship between these various themes and work towards a more sophisticated theoretical basis for considering the many 'transit migrations' which are discussed.

\section{References}

Bensaad, A. (2005), 'Les migrations transsahariennes: Une mondialisation par la marge', Maghreb-Machrek 185: 13-36.

Brubaker, R. \& F. Cooper (2000) 'Beyond “identity”, Theory and Society 29 (1): 1-47.

Castells, M. (1996), The Rise of the Network Society. Oxford: Blackwell.

Collyer, M. (2008), Towards Mediterranean Migration Management? Developing Discourses and Practices, ARI. Madrid: Real Instituto Elcano.

Collyer, M. (2010), 'Stranded migrants and the fragmented journey', Journal of Refugee Studies 23 (3): $273-293$.

Collyer, M., F. Düvell \& H. de Haas (2010), 'Critical approaches to transit migration', Special issue of Population, Space and Place. 
Cuttitta, P. (2005), 'Delocalisation of migration controls to Northern Africa'. Paper submitted to workshop "The Europeanisation of National Immigration Policies”, Berlin, 1-3 September.

De Haas, H. (2007), The Myth of Invasion: Irregular migration from West Africa to the Maghreb and the European Union. Oxford: International Migration Institute.

Düvell, F. (2006), 'Crossing the fringes of Europe: Transit migration in the EU's neighbourhood'. Working Paper 6-33. Oxford: Centre on Migration, Policy and Society.

Düvell, F. \& D. Vogel (2006), 'Polish migrants: Tensions between sociological typologies and state categories', in A. Triandafyllidou (ed.), Contemporary Polish Migration in Europe: Complex Patterns of Movement and Settlement. Lewiston: Edwin Mellen Press, 267-289.

Düvell, F. \& B. Vollmer (2009), Irregular Migration in and from the Neighbourhood of the EU: A Comparison of Morocco, Turkey and Ukraine. Athens: Eliamep, http://clandestino.eliamep. gr/wp-content/uploads/2009/11/transit_report_compas_septog1.pdf.

European Commission (DG Trade) (2009), 'EU bilateral trade and trade with the world', 22 September. Brussels: European Commission.

Hamood, S. (2006), African Transit Migration through Libya to Europe: The Human Cost. Cairo: FMRS, AUC.

ICMPD (International Centre for Migration Policy Development) (2007), Mediterranean Transit Migration. I-Map available at www.imap-migration.org/.

Papadopoulou-Kourkoula, A. (2008), Transit Migration: The Missing Link Between Emigration and Settlement. Basingstoke: Palgrave.

Pliez, O. (2005), 'Le Sahara libyen dans les nouvelles configurations migratoires', Revue Européenne des Migrations Internationales 16.

Schoorl, J., L. Heering, I. Esveldt, G. Groenewold, R. van den Erf, A. Bosch, H. de Valk \& B. de Bruin (200o), Push and Pull Factors of International Migration: A Comparative Report. Luxembourg: Eurostat.

Temime, E. (1989), Marseille Transit: Les passagers de Belsunce. Paris: Autrement.

United against Racism (2013), Death by Policy: The Fatal Realities of 'Fortress Europe'. Amsterdam: United, available at www.unitedagainstracism.org/pages/underframeFatalRealitiesFortressEurope.htm.

Wallace, C., O. Chmouliar \& E. Sidorenko (1996), 'The eastern frontier of Western Europe: Mobility in the buffer zone', New Community 22 (2): 259-286.

Zetter, R. (2007), 'More labels and fewer refugees: Remaking the refugee label in an era of globalization', Journal of Refugee Studies 20 (2): 172-192. 



\section{Part 1}

The Mediterranean Quadrants 



\title{
2 Migrants' Uncertainties versus the State's Insecurities
}

\author{
Transit Migration in Turkey
}

Ahmet $\dot{I}_{c ̧} d u y g u$ \& Deniz Sert

\subsection{Introduction}

He's in Turkey illegally, having already been deported back to his native Iran once before. An Iranian Kurd, he was in prison for his political beliefs, and - as he put it - for thinking un-Islamic thoughts. Twice now, he's paid $\$ 500$ to be smuggled by night across the steep mountain passes into Turkey (Morris 1998).

Since the early 1980s, Turkey has become an important route for so-called transit migration flows in the south-east of Europe. People from different parts of the South and East have begun to use the Turkish peninsula as a bridge to the West and the North, where they hope to find better living conditions. The number of such people is unknown as there are no figures available for 'irregular transit migration' passing through Turkey, which is an expected result, given the murky nature of this phenomenon. The only existing data cover the number of irregular migrants who were apprehended in Turkey between 1995 and 2009, with a total figure of around 800,000 , as compiled by the Bureau for Foreigners, Borders, and Asylum at the Directorate of General Security of the Ministry of Interior.

The issue of irregular transit migration is receiving increasing attention from the media in Turkey - with a special focus on the misfortunes of those irregular migrants who try to cross the Aegean Sea between Turkey and Greece - as well as from policymakers and government officials who are under constant pressure from the European Union to stop the tide of irregular migration and from non-governmental and international organisations that are concerned about the humanitarian and human rights aspects of the issue (Kirişci 2008).

In this chapter, the issue of transit border crossings in Turkey is presented from two different perspectives. Based on Anthony Giddens' (1996) argument that 'ontological uncertainty/insecurity' has become an essential constituent of life in the post-Cold War era, as far as the transit migration 
issues are concerned, we see Turkey as a platform for two parallel environments. The first environment, which is inhabited by irregular transit migrants, is full of uncertainty, where the dynamics of migration entail an innovative normative view that does not treat migrants as a security threat in an a priori fashion (Appadurai 1996), but as humans living with ambiguity and facing an unclear future. The second environment, which is envisioned by the Turkish state, defines migration in terms of insecurity - a view that Appadurai warns against.

The chapter is divided into four parts. The first section gives facts and figures regarding transit border crossings and presents a taxonomy delineating who is considered an 'irregular transit migrant' in Turkey. In the second section, the 'environment of uncertainty' faced by migrants is analysed with details on the experience and nature of irregular migration in Turkey. In the third section, the Turkish state's 'environment of insecurity' is examined with a focus on the policies and actions created to manage irregular transit migration. Irregular transit migration as an issue within EU-Turkish relations is also considered in this section, which is followed by the conclusion.

The chapter is based on various sources. The facts and figures are derived from the data compiled by the Bureau for Foreigners, Borders, and Asylum at the Directorate of General Security of the Ministry of Interior, on the number of irregular migrants apprehended in Turkey since the mid-199os, and on new data released by the Turkish General Staff on irregular border crossings since September 2006. The context of the transit migrants is analysed through a comparison of two studies commissioned by the International Organization for Migration: Transit Migration on Turkey (IOM 1995) and Irregular Migration in Turkey (İçduygu 2003). Although the methodology of these studies is not based on representative sampling, and their findings cannot be generalised, they are pioneers within a limited scholarly literature on transit migration in Turkey. They provide insight into the personal attributes of transit migrants who face an uncertain environment in Turkey and convey information about irregular transit migration in the country, in general.

\subsection{Transit border crossings in Turkey: Some facts}

There are 117 official points of entry into Turkey: seven by rail, 41 by air, 20 by land and 49 by sea. While Turkey's sea border measures $8,333 \mathrm{~km}$ in total, the total length of the country's land border is $2,949 \mathrm{~km}$. Turkey shares 269 $\mathrm{km}$ borders with Bulgaria, $203 \mathrm{~km}$ with Greece, $276 \mathrm{~km}$ with Georgia, $328 \mathrm{~km}$ 
with Armenia, $18 \mathrm{~km}$ with Azerbaijan, $560 \mathrm{~km}$ with Iran, $384 \mathrm{~km}$ with Iraq, and $911 \mathrm{~km}$ with Syria. Turkey's geographical position is the main reason why the country is susceptible to irregular transit border crossings, turning it into an almost natural bridge between its politically and economically unstable neighbour countries in the East and the South and its prosperous neighbours in the West and the North. Moreover, Turkey's mountainous eastern borders and the length of its Aegean and Mediterranean shores make it an attractive travel route for irregular transit migrants. Transit migrants enter Turkey in many different ways: by using forged documents; by hiding in vehicles passing across land borders; by passing land borders on horses, donkeys, or on foot; by crossing sea borders on ferries, fishing boats or small boats; or by entering the country legally but failing to leave when their visas expire (İçduygu \& Toktaş 2002).

The task of acquiring adequate, reliable data on the volume and trends of transit migration is difficult because of its irregular nature, but there are some rough estimates available. The data compiled by the Bureau for Foreigners, Borders, and Asylum at the Directorate of General Security of the Ministry of Interior, on the number of irregular migrants apprehended in Turkey since the mid-199os, and new data released by the Turkish General Staff on irregular border crossings since September 2006, give us some figures which implicitly reveal the nature of transit migration through Turkey. An evaluation of the figures on persons apprehended by Turkish security authorities on charges of irregular migration shows that this type of migration has increased considerably from the mid-199os to the early 2000s. While almost 11,000 and 19,00o irregular migrants were apprehended in 1995 and 1996, respectively, the number increased to 47,000 in 1999 and 94,000 in 2000 (table 2.1). Since 2001, the number of irregular migrants apprehended has shown a decreasing drift from nearly 83,000 in 2002 to less than 50,000 in the year 2005, with only a slight rise to nearly 52,000 in 2006. This recent rising trend continued in 2006 and 2007, when 64,000 and 66,000 migrants were apprehended respectively (table 2.1). It is important to note that the figures stand for only those irregular migrants who were actually apprehended and that the scale of irregular migration through Turkey is naturally much greater than these data suggest. Taking into consideration the relevant literature on migration, it can be inferred that the actual number would be at least two or three times higher than the number of migrants apprehended (İçduygu 2007a). ${ }^{1}$ Consequently, the scale of such

1 Various field studies conducted by Içduygu, mainly at the two borders of Turkey the ones between Iran and Turkey, and Greece and Turkey, since the early 199os indicated that even 
a figure illustrates that the range of irregular migration within Turkey in recent years is analogous to that in many other countries of the world that are known to attract large-scale irregular immigration.

Of course, not all these apprehended migrants in Turkey were transit migrants. However, the estimates of transit migrants in the country are also based on assumptions inferred from the data on the number of migrants apprehended. Taking into consideration the countries of origin of the apprehended irregular migrants, it can be claimed that those migrants entering Turkey especially from the Eastern and Southern borders intend to use Turkey as a bridge to reach their destination countries in the West and North. From 1996 to 2008, almost 800,00o irregular migrants were apprehended in Turkey and nearly half of them seemed to be transit migrants (table 2.1). Thus, it can be deduced from the above data that at the beginning of the 2000s, around 51,000 to 57,000 transit migrants a year had intentions to pass through Turkey annually. Currently, this number seems to have fallen to the level of 20,000 to 30,000 . Most transit migrants had entered the country illegally through human smuggling, though the recent liberalisation of Turkey's visa policy enables more people to arrive legally and on regular flights, though they then leave or attempt to leave with the help of smugglers. It appears that over the period of 1995-2008, the five primary source countries for irregular migrants, who were typically transit migrants, were Iraq, Pakistan, Afghanistan, Iran and Bangladesh (table 2.2). The recent in- and outflow of Syrian refugees is not yet reflected in these older figures.

according to the border security officers the actual number was at least two or three times higher than the number of migrants apprehended. 


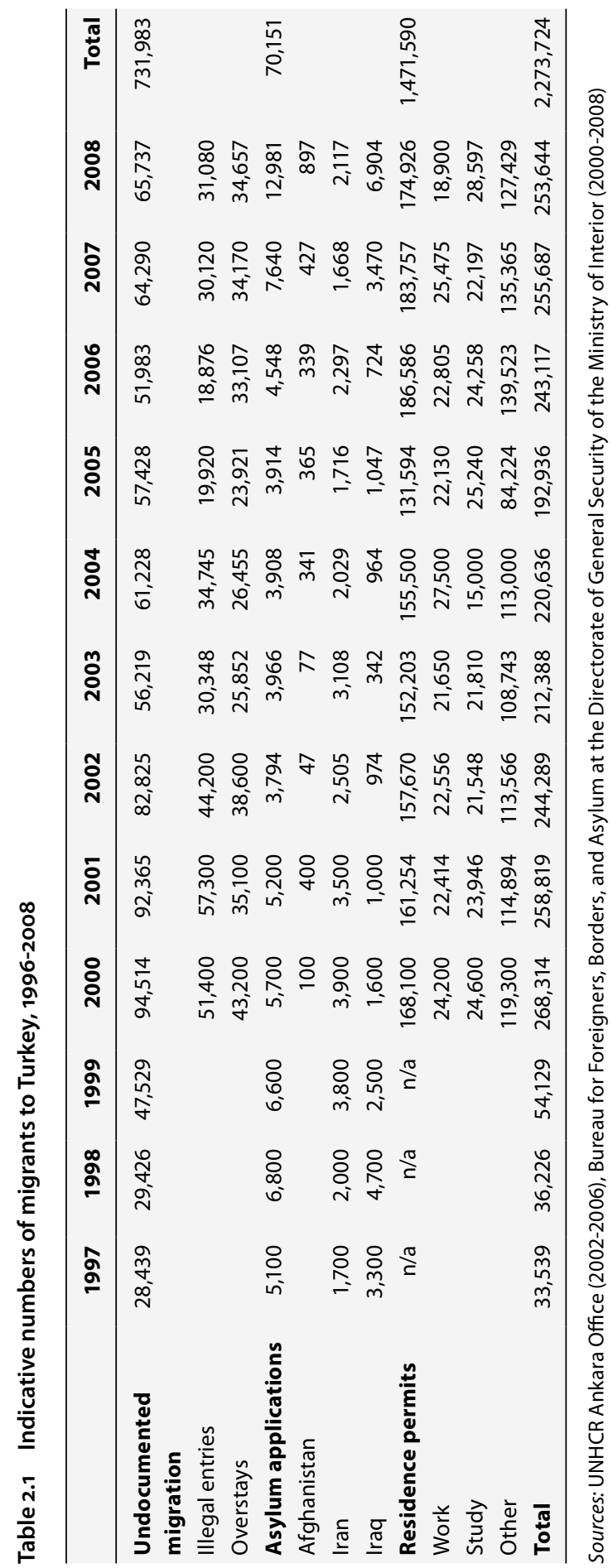




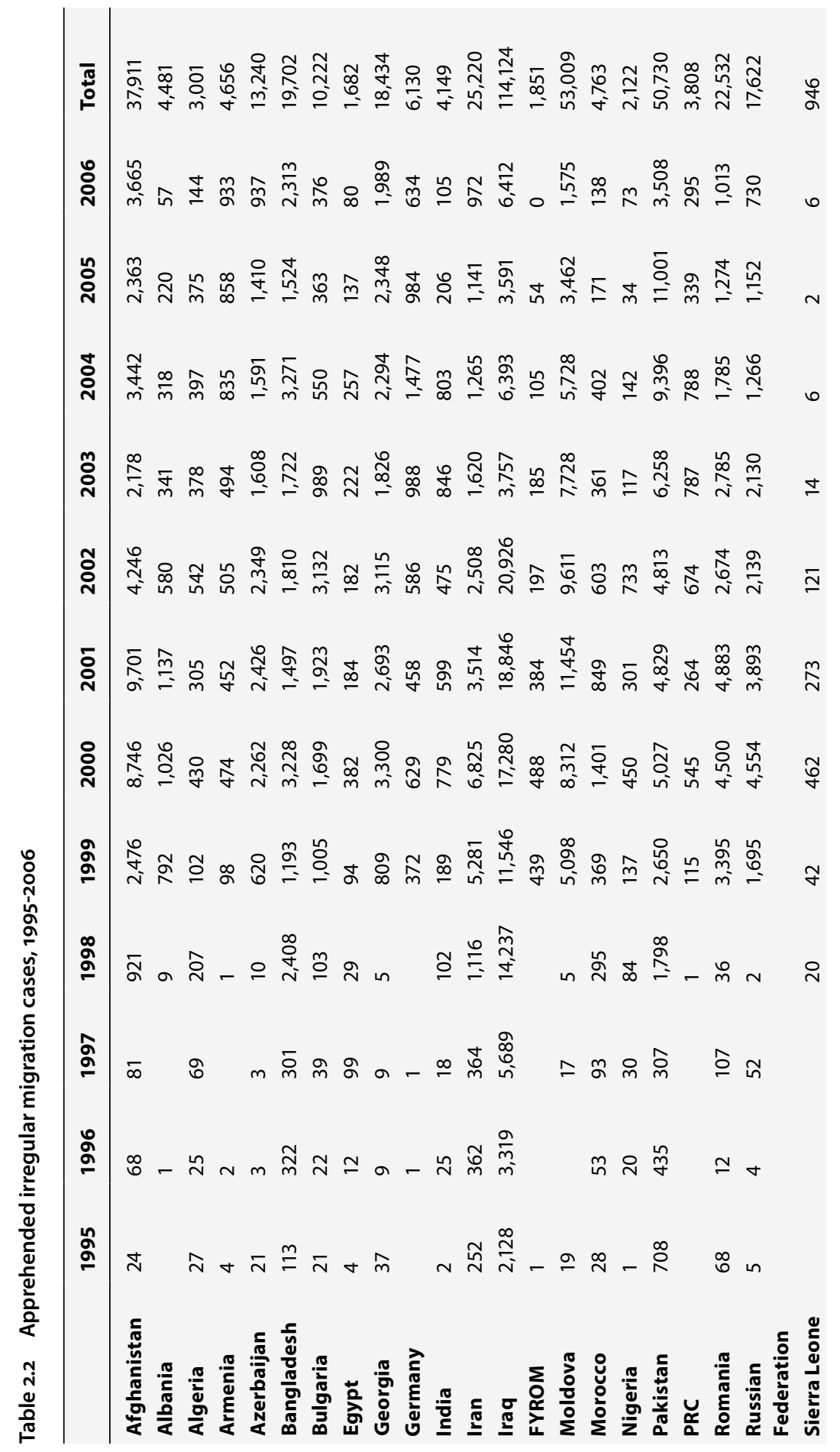




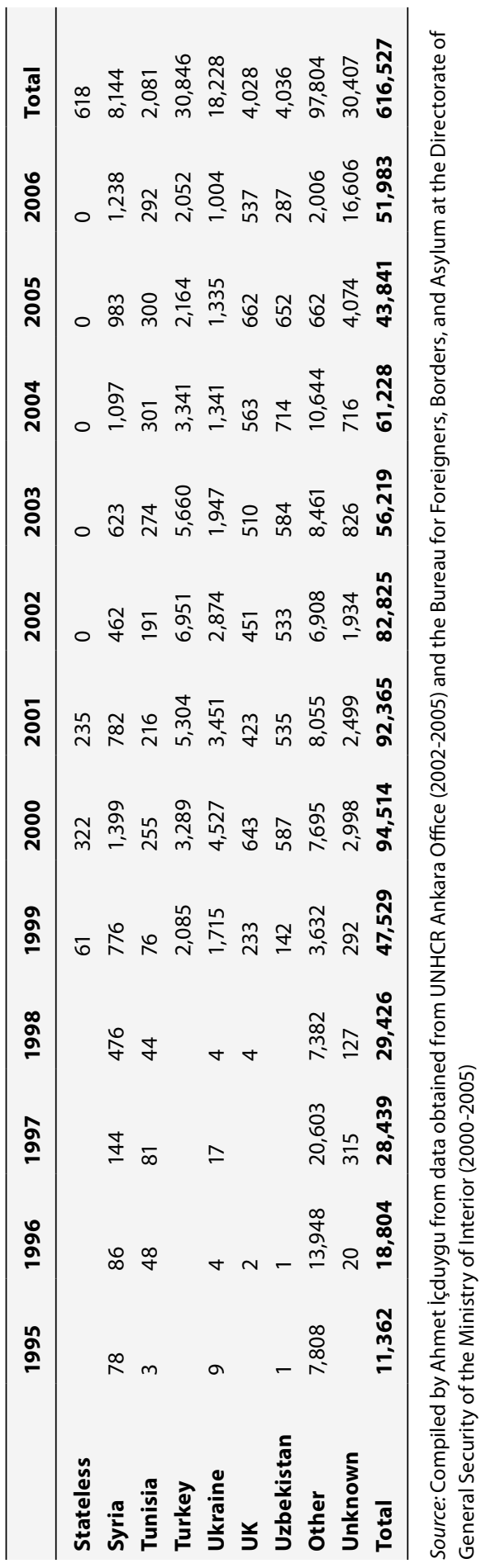


As mentioned earlier, information published by the Turkish General Staff on irregular border crossings since September 2006 comprises recent data, which present certain figures that expose characteristics of transit migration through Turkey. This new data on irregular border crossings is largely complementary to the information provided by the Security Forces detailed above. Based on this new data, there were about 102,000 foreign citizens apprehended in the period September 2006-June 2009 because they infringed the rules of border crossings in Turkey. Thus, on average, almost 100 persons are detained on the borders of Turkey on a daily basis. Looking at the monthly pattern of these apprehensions, it is seen that irregular border crossings increase in the month of September and decrease in the winter months of January and February (figure 2.1). It can be inferred from these figures that climate conditions affect both the scale of migration and/or the success of the border guards in apprehending irregular border crossers.

Figure 2.1 'Illegal' border crossings by season, 2006-2009

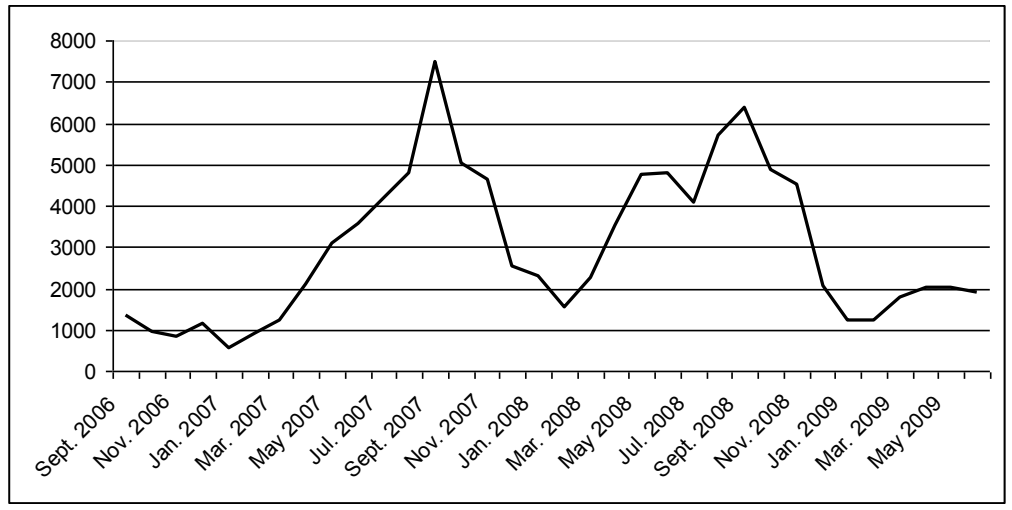

Source: Compiled by the authors based on the data provided by the Turkish General Staff

Based on the same data, in the period between September 2006 and February 2008 , while 21 per cent of those irregular border crossers were from the Palestinian Territories, 19 per cent were from Iraq, 11 per cent from Afghanistan, another 10 per cent from Mauritania, 10 per cent from Pakistan, and 8 per cent from Somalia. The data point out that nearly 35 per cent of these irregular border crossers were caught on the borders between Greece and Turkey while they were departing, and the majority of those remaining were apprehended on the eastern borders of Turkey (mostly on the Iraqi, Iranian and Syrian borders) while they were entering the country (figure 2.2). 
Figure 2.2 'Illegal' border crossings by location, 2006-2008

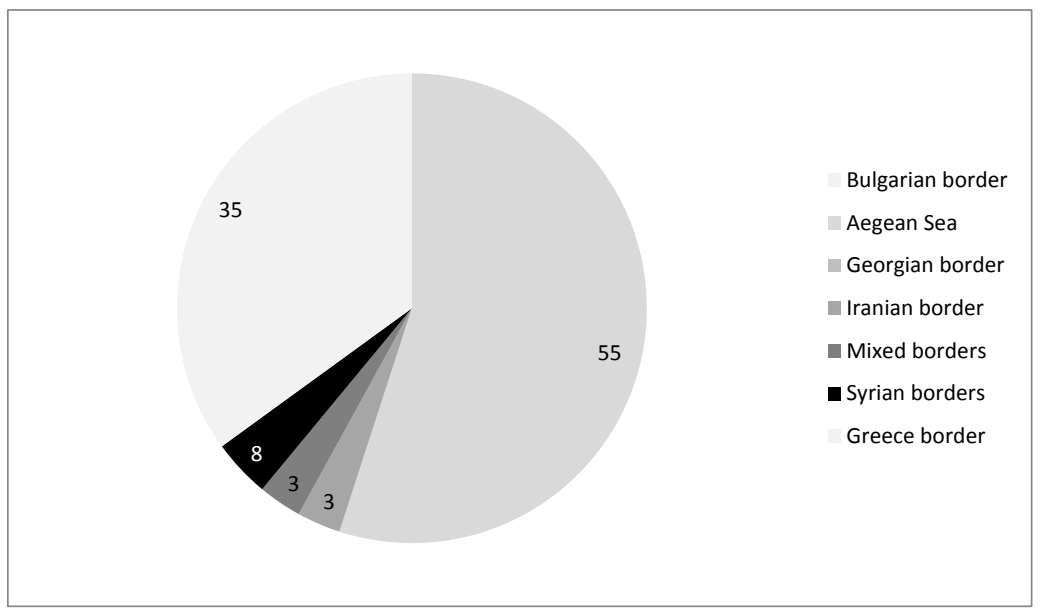

Source: Compiled by the authors based on the data provided by the Turkish General Staff

Asylum seekers in Turkey are also a potential source of transit migration, partly because Turkey is a bridge between Asia, Europe, and Africa, and partly because of Turkey's geographical limitation in the $195^{1}$ Geneva Convention. Since the 1980s, Turkey has been one of the key arrival points for many asylum seekers from its eastern peripheries - which are beset by political irregularities, problems, and turmoil - a large majority being citizens of Iran and Iraq. In fact, this completely conflicts with the geographical limitation clause that Turkey recorded while signing the Geneva Convention of 1951. The clause states that Turkey would only consider asylum applications made by persons from European countries and would not accept any responsibility for asylum seekers from outside Europe. ${ }^{2}$ While the geographical limitation is in place, almost all persons seeking asylum

2 This is partly related to the refugee problem in post-war Europe and is partly a ramification of the anti-communism policies that Turkey adopted during those years, meaning Turkey would grant asylum to persons who arrived from the Soviet Union and Eastern Europe during the Cold War. With its absolute pledge for protection and placement of persons fleeing communist regimes, in particular, Turkey undertook to serve a very limited number of asylum seekers. In fact, during the Cold War years, migratory movements in Turkey involving asylum seekers from the Soviet Union and Eastern Europe were scarce and limited, with their numbers being notably low. According to the UNHCR data, between 1945 and 1991, less than 8,000 asylum applications from the Soviet Union and Eastern European states were filed with Turkish authorities as per Turkey's position under the Geneva Convention of 1951. More than half of these applications were filed between 1979 and 1991 (İçduygu 2003). 
in Turkey are non-European - mostly of Iranian and Iraqi origin. In reality, this limitation is not employed: non-European asylum seekers are granted temporary asylum and, once they are granted refugee status through a joint procedure of the UNHCR and the Ministry of Interior, they are resettled to a third country. This asylum process turns Turkey into a transit country for those people who have been granted refugee status and are waiting for resettlement, which reflects the definition of transit migrants as 'refugees awaiting resettlement' (IOM 2004: 53). In fact, from 1997 to 2008, more than 27,000 of the total of 56,000 asylum seekers (more than 48 per cent) were granted refugee status and re-settled in other countries, making them transit migrants in Turkey in the last ten years. ${ }^{3}$ Later, 14,000 asylum seekers were waiting for their status to be determined and more than 10,000 refugees were waiting for resettlement. These numbers further increased in 2013, when the number of refugees (excluding Syrian refugees) reached over 33,000 and thus record levels. In the meantime, both groups have come to form a segment of overall transit migration in Turkey. Thus, the movement of asylum seekers and that of transit migrants often amalgamate and the distinctions between transit migration, irregular migration, and asylum seeking are often blurred.

\subsection{Environment of uncertainty}

I left Iran illegally with the help of an 'agent' - crossing the border with Turkey. I spent 10 days in a 'safe house' - a secret location where you cannot go out. I paid $\$ 8,000$ to escape. It is a lot of money: but if it's about your life - I think you will pay even more if you need to. I travelled in different cars all the time and at night-time. Like a James Bond film. But James Bond always lives. You maybe die. Sometimes I was travelling with other people - sometimes not. The route is secret and you always travel at night so you don't know where you are. I don't know what countries I travelled through. I know I went through Turkey, but nowhere else. I was not fearful, just glad to escape. I have never done anything illegal in my life - but I had to leave (BBC 2008).

Not only is the line blurred between transit migration, irregular migration, and asylum seeking, but these groups all face an uncertain future. Transit

3 For a detailed elaboration of these figures, see the UNHCR Ankara Office webpage www.unhcr.org.tr. 
migrants often find themselves in an environment of uncertainty, which is a result of three main factors. First, most transit migrants are irregular border crossers and their 'illegality' makes them more vulnerable than other migrants. The irony is that while living in constant fear of apprehension by transit country security forces, transit migrants also lack the protection provided by those same forces. Moreover, their 'illegality' deprives them of employment and housing rights as well as health services and/or education. The second factor adding to their environment of uncertainty is their 'temporary' situation. Transit migrants, by the nature of their migration, are directed towards a third country, but the duration of their temporary transit situation is usually unknown. Third, transit migrants' movements are usually facilitated by human smugglers or traffickers, and thus they often have no control over their crossings, or sometimes even over their destination. Thus, the environment faced by transit migrants is defined here as uncertain because of the 'illegal', vulnerable, temporary, and restraining nature of transit migration.

Transit migrants' environment of uncertainty in Turkey can be better understood through an analysis and comparison of two studies commissioned by the International Organization for Migration: Transit Migration in Turkey (IOM 1995) and Irregular Migration in Turkey (İçduygu 2003). These studies, besides being pioneers within a limited scholarly literature on transit migration in Turkey, also provide insight into the personal attributes of transit migrants who face an uncertain environment in Turkey and convey information about irregular transit migration in the country in general.

The 1995 IOM study, which was based on interviews with 159 irregular transit migrants in Istanbul and Ankara, exclusively focused on transit migrants, reflecting on five major groups of irregular transit migrants in Turkey: Iranians, Iraqis, Bosnians, Africans and others who were mostly Asians. Almost 75 per cent of the transit migrants in the sample were men, 60 per cent were below the age of 30 , and more than 60 per cent were either single or divorced. Contrary to the conventional wisdom that most irregular migrants are from rural areas, unskilled and/or uneducated, most of them were born in urban areas, had obtained some education, and had been employed prior to migrating. A significant number of them came to Turkey without valid documents and without enough information about the country prior to their arrival. Almost one out of three respondents was preparing to employ traffickers/smugglers in order to reach their final destination, mainly named as Denmark, Greece, Sweden, the United Kingdom, Australia, Canada, and the USA. 
The second IOM study in 2003, which was based on interviews with 53 irregular migrants in Istanbul and Van provinces, mainly concentrated on irregular migrants in general, and not only on transit migrants. Almost one-quarter of the sample were Iranians and Iraqis, another 14 per cent were Afghanis, and the remainder were from some of the former Eastern bloc and African countries. Still, the study highlighted those migrants who largely regarded Turkey as a transit area en route to the West. This group represented the irregular transit migrants who also wanted to leave illegally. Like the 1995 sample, the 2003 sample contradicted the stereotypical view of irregular transit migrants as young, unmarried, poor, uneducated and unskilled males from rural backgrounds. On the contrary, the sample showed that irregular transit migrants in Turkey were mainly young, married men and women, from diverse national and ethnic backgrounds and with a considerable degree of formal education and experience in urban areas. Like their 1995 counterparts, a majority of these individuals had already worked in their countries of origin before migrating.

While a large percentage of the irregular transit migrants interviewed in the 2003 IOM study had crossed the borders without valid travel documents, only 40 per cent of the respondents in the 1995 study indicated that they had entered Turkey without a valid document. The finding indicates that there were more illegal entries in 2003 than in 1995, which is confirmed by the official statistics which show increases in the second half of the 1990s, mentioned above. Almost 55 per cent of the 2003 respondents reported that their approximate monthly income was either low or below average, while 4 per cent had not received any income at all. They were usually illegally employed in precarious and low-paid jobs, the so-called $3^{\mathrm{D}}$ jobs (dirty, difficult and dangerous), due to their illegal status. The 1995 respondents were in a relatively better situation as two-thirds considered their income to be average, indicating that later-comers had a worse economic status as compared with their forerunners from 1995.

The housing conditions for irregular transit migrants were generally stated as very poor in both studies. In the 2003 study, half of the respondents shared rented accommodation, 10 per cent lived alone, 8 per cent lived with friends, 4 per cent with relatives and 4 per cent lived at their workplace, while 6 per cent lived in hotels and 10 per cent in shelters. In a different study conducted in Istanbul, the migrants interviewed mentioned that while finding housing was not very difficult, without any legal status and regular employment many had to shelter together, sometimes up to ten people in a single room, gathering together in apartments that were badly equipped to house them (İçduygu \& Biehl 2008). 
As stated earlier, by its very nature irregular transit migration tends to become entangled with asylum seeking processes in Turkey. While the number of asylum applications was lower in the 1995 study, 27 per cent of the irregular migrants interviewed for the 2003 study had applied for asylum and only 6 per cent had actually been granted refugee status. Many of these transit migrants have arrived in Turkey without valid travel documents, with the help of smugglers, making the wish to migrate a considerable economic burden on the migrant and his or her family members. The bribes and payments to the smugglers make the whole process of migration expensive. Both studies revealed that smugglers and traffickers are frequently used and transit migrants have no control over the travel arrangements made by such intermediaries. Some 59 per cent of the sample group in the 2003 study and almost 71 per cent of the respondents in the 1995 study had already attempted to leave Turkey, mostly through paying such intermediaries fees ranging from $\$ 50$ to $\$ 15,000$.

Thus, as described earlier, the line between transit migrants and asylum seekers is blurred: the majority find themselves forced into practices of 'illegal' border crossing, living in precarious situations and denied employment and housing rights. Because such migrants typically enter the country without valid documents, they are often stuck waiting for the right moment to be smuggled. The duration of the wait is usually unknown. It typically depends on various factors ranging from availability of funds to the fees demanded by the smugglers to climate conditions, and even to the policies of both the transit and destination countries. Some days are better for taking action than others, but agency usually lies in the hands of other intermediaries, leaving the transit migrants with less control over their futures.

\subsection{Environment of insecurity}

Turkish security forces arrested a total of 44 illegal migrants in separate operations, officials said on Saturday. A coast guard boat spotted a rubber boat off Karaburun town of the Aegean province of Izmir with 25 illegal migrants and a Turkish human trafficker on board. Somali and Bangladeshi illegal migrants, who were trying to reach Greek islands, and the Turkish human trafficker were arrested. In a separate operation in the north-western province of Edirne, gendarmerie and border patrol teams caught 19 illegal migrants of Iraqi, Palestinian and Burmese descent. All illegal migrants would be deported, police said (Sabah Newspaper 2009). 
The concept of security has broadened and migrants have been linked to certain risks (Ibrahim 2005: 164). Policymakers now tend to treat immigration as a security threat. The Turkish state apparatus is no exception. Turkish policymakers envision transit migration within an environment of insecurity where two different dynamics function at the same time. On the one hand, protection of the borders is a national security issue by its nature and illicit border crossers simply violate the law of the state. However, the phenomenon of transit border crossers is more complicated: the fact that they intend to move on to third countries also makes the transit country accountable towards those third countries that are, most often, its neighbours. In the case of Turkey, the migrant-receiving neighbours are EU members who increasingly view immigration as a national security issue, and who have become more and more concerned about transit migration in particular. While the issue of transit migration had been on the European agenda since the 1990s, when many illegal immigrants appeared on the shores of Greece, Italy and Spain, the fact that the terrorists who attacked New York (11 September 2001), Madrid (11 March 2004), and London (7 July 2005) were considered to have immigrant backgrounds strengthened the view that immigration is a source of insecurity and uncertainty that encircles the economic, social and political spheres of the region. An analysis of discourses on transit migration within the EU reveals how migration is securitised by building upon the idea that transit migration leads to a chaotic migratory system (İçduygu \& Yükseker 2008). It is within this setting that Turkey, due to its geographical position as a transit country, has attracted a lot of policy attention from its European counterparts during the accession negotiations with the EU.

On the other hand, as the intermediaries of irregular border movements, smugglers and traffickers are integral parts of transit migratory flows while also being important constituents of criminal networks. There are diverse reactions regarding human trafficking and smuggling. Some think that such actions are among the unavoidable outcomes of the globalised dynamics of contemporary human mobility (İçduygu \& Keyman 2000: 383-384; İçduygu \& Ünalan 2002: 3-6). Others regard such actions as major illegal activities led by organised criminal groups (IOM 2000: 8-11; SMOFA 2001), while still others argue that, as migrant-receiving countries tighten the means of legal immigration, the only way for many potential migrants to enter these countries is through irregular border crossings where smugglers and traffickers act as intermediaries (Graycar 2000; İçduygu 2000: 358; Salt 2000: 32; İçduygu \& Toktaş 2002).

Within this environment of insecurity, where both national security and criminal networks are at stake, Turkey has taken several legal measures and 
pursued various international collaborations to counter irregular migration into the country. To illustrate, in August 2002, the government instituted new clauses to the Penal Code that criminalised human smuggling and trafficking, while establishing firmer controls at the borders and ports. Article 79 of the new Turkish Penal Code Law No 5237, put into force in 2005, classified migrant smuggling and established punishments of three to eight years of imprisonment and judicial fines corresponding to 10,000 days in jail. In the case that an act of human smuggling is proven to be an organised crime, the penalty is increased by half. Article 79 also provided for coercive measures (confiscation of assets, etc.) against legal entities involved in human smuggling. In the meantime, based on the Road Transportation Law (2003) and the Road Transportation Regulation (2004), if a person is sentenced for migrant smuggling, his/her transportation permit cannot be renewed for three years and the person's vehicle is confiscated by the Turkish authorities. Furthermore, as another domestic measure in the fight against illegal immigration, the Law on Work Permits for Aliens, which was enacted in 2003, authorised the Ministry of Labour and Social Security to issue all types of work permits for foreigners to make sure the process is better managed and controlled to avoid illegal employment of foreigners.

On a more international level, in March 2003, the Turkish Grand National Assembly recognised the United Nations Convention against Transnational Organized Crime and its Additional Protocol against the Smuggling of Migrants by Land, Sea and Air, and introduced legal actions in accordance with the agreement. Furthermore, Turkey became a full member of the IOM in 2004, when it embarked on international collaboration to combat human trafficking and addressed several migration issues in general. Moreover, in January 2006, Turkey assumed the Presidency of the Budapest Process, which is an unofficial forum for inter-governmental cooperation and dialogue, involving fifty governments and ten international organisations. The forum aims to prevent irregular migration and establish sustainable mechanisms in the field of migration management.

In terms of further international cooperation, in order to slow down or even end illegal migration, Turkey has also signed readmission agreements with those countries of origin whose citizens are among the larger groups of irregular transit migrants. Such agreements have been signed with Syria, Kyrgyzstan, Romania, Ukraine, and Greece, while negotiations with Pakistan are still continuing. In September 2000, the European Commission was also given the mandate to negotiate a readmission agreement with Turkey. The EC negotiators thought that as a candidate country with a possibility of accession, Turkey had an incentive to negotiate a readmission 
agreement (Paalman interview 2005 in Long \& Celebic 2006). However, afraid of becoming a border zone, the Turkish negotiating team argued that such an agreement would come into force automatically on Turkey's entry into the EU and was therefore unnecessary, and tied its signature of the readmission agreement to completion of the accession process.

As the discussion above also reveals, irregular migration and other issues related to it have become an integral part of Turkey's EU membership debate. Within this context, an important agenda item in EU-Turkey relations is how Turkey's state institutions and legal frameworks can manage incoming migration and asylum flows. Thus, as detailed elsewhere (see İçduygu $2007 \mathrm{~b}$ ), the strength and stability of Turkey's integration into the $\mathrm{EU}$ is subject not only to the economic, social, and political makeovers in the country, but also explicit policy matters.

From the EU's perspective, this was a result of the political discourse with which transit migration is associated, where some published materials presented the phenomenon as yet another threat to Europe (Düvell 2006: 6), and where the concentration and assets dedicated to fight against it already far exceeded its quantitative significance (Collyer 2006:3). In one such publication, transit migration through Turkey was 'viewed as one of the most common of all recently established mobility flows between Africa and Asia and countries of Europe' where 'it has become clear that thousands of migrants from the developing world who enter Europe are using Turkey as a transit area on their way to their preferred destinations' (IOM 1995: 4; also cited in Düvell 2006). Within this context, since Turkey's candidature to Union membership in 1999, the EU has required Turkey to securitise migration within its borders and to conform fully to the norms of the international refugee regime. Ultimately, both requirements call upon Turkey to devote more resources and energy to managing migration and asylum flows across and within its borders.

From the Turkish side, as implied by the discussion of a possible readmission agreement between the EU and Turkey, there is a feeling that EU policies and practices for managing migration shift the burden of controlling migration to countries on the periphery, like Turkey, turning them into buffer zones between the immigrant-attracting European core and the emigrant-producing peripheral regions. Thus, Turkish policymakers regard the EU's efforts as burden-shifting and try to promote policies that would lead to burden-sharing instead. Within this context, irregular migration and transit border crossings in particular go beyond national security, for they are also key features of an international environment of insecurity where EU-Turkey relations are also at stake. 


\subsection{Conclusion}

I paid $\$ 7,000$ to human traffickers so that they take me from Iraq to Greece. They took me through mountains and everywhere, it took me 10 days to get there. But then Greece authorities they sent us back to Turkey. I am not a criminal, I am an engineer. I have done nothing against anybody I just want a safe place (Jones 2009).

In this chapter, we have tried to show that transit border crossings in Turkey can be perceived from two different standpoints. On the one hand, transit migration has been politicised by policymakers and government officers. Under this policy discourse, the phenomenon has become a euphemism for 'illegality', and therefore, a domain of insecurity both for Turkey and the EU - as transit migratory flows through Turkey are usually destined for Europe. On the other hand, transit migrants find themselves in an environment of uncertainty 'with a temporary status of non-belonging that results in exclusion from conventional protections regimes' and which results in 'various human rights concerns' (Düvell 2006). Thus, transit border crossings into and out of Turkey are envisioned in a twofold environment of insecurity and uncertainty, which is perceived by the actors involved - transit migrants and state officers - very differently. It seems that they are different in terms of the dissimilar position of these actors, but as far as the wider picture of irregular transit migratory flows is concerned, they are complementary to each other.

\section{References}

Appadurai, A. (1996), Modernity at Large. Minneapolis: University of Minnesota Press.

BBC (2008), 'Migrant stories', BBC News Web Edition, 30 January, British Broadcasting Corporation.

Collyer, M. (2006), 'States of insecurity: Consequences of Saharan transit migration'. Working Paper No. 31. Oxford: Centre on Migration, Policy and Society.

Düvell, F. (2006), 'Crossing the fringes of Europe: Transit migration in the EU's neighbourhood'. Working Paper No. 33. Oxford: Centre on Migration, Policy and Society.

Giddens, A. (1996), Beyond Left and Right. Oxford: Polity Press.

Graycar, A. (2000), 'Human smuggling'. Canberra: Australian Institute of Criminology, Unpublished Paper.

Ibrahim, M. (2005), 'The securitization of migration: A racial discourse', International Migration $43(5): 163-187$.

İçduygu, A. (2000), 'The politics of international migratory regimes: Transit migration flows in Turkey', International Social Science Journal 165: 357-368. 
İçduygu, A. (2003), 'Irregular migration in Turkey'. IOM Research Series No. 12. Geneva: International Organization for Migration.

İçduygu, A. (2007a), 'The politics of Irregular migratory flows in the Mediterranean Basin: Economy, mobility and “illegality"', Mediterranean Politics 12 (2): 141-161.

İçduygu, A. (2007b), 'EU-ization matters: Changes in immigration and asylum practices in Turkey', in T. Faist \& A. Ette (eds), The Europeanization of National Policies and Politics of Immigration. London: Palgrave Macmillan.

İçduygu, A. \& K. Biehl (2008), The LivingTogether Programme:Migrant Cities Research-Istanbul. Istanbul: The British Council.

İçduygu, A. \& E.F. Keyman (2000), 'Globalization, security, and migration: The case of Turkey', Global Governance 6: 383-398.

İçduygu, A. \& Ş. Toktaş (2002), 'How do smuggling and trafficking operate via irregular border crossing in the Middle East? Evidence from fieldwork in Turkey', International Migration 40: $25-54$.

İçduygu, A. \& T. Ünalan (2002), 'Tides between Mediterranean shores: Undocumented migration in the south of Europe'. Working Paper No. 7. Ankara: Hacettepe University Institute of Population Studies.

İçduygu, A. \& D. Yükseker (2008), 'Irregular migration in Turkey: A survey in the early 200os'. Paper prepared for IMISCOE Conference on 'Irregular) Transit Migration in the European Space: Theory, Politics, and Research Methodology', Istanbul, 18-19 April.

IOM (1995), Transit Migration in Turkey. Budapest: International Organization for Migration Information Programme.

IOM (2000), Myths and Realities of Chinese Irregular Migration. Geneva: International Organization for Migration.

IOM (2004), International Migration Law: Glossary on Migration. Geneva: IOM.

Jones, D. (2009), 'Turkey struggles to cope with annual illegal immigrant influx', Phantis 1 July.

Kirişci, K. (2008), 'Managing irregular migration in Turkey: A political-bureaucratic perspective'. Paper prepared for CARIM Analytic and Synthetic Notes - Irregular Migration Series Socio-Political Module, No. 61.

Long, L.D. \& S. Celebic (2006), 'Perspectives on the EC/Albanian Readmission Agreement', in Return and Readmission to Albania:The Experience of Selected EUMember States. Tirana: IOM.

Morris, C. (1998), 'Illegal migrants from Turkey', BBC News Web Edition.

Sabah Newspaper (2009), 'Security forces catch 44 illegal migrants in Turkey', 5 July, English Edition.

Salt, J. (2000), 'Trafficking and human smuggling: A European perspective from Asia', International Migration 38 (3): 31-56.

Smith, H. (2007), '50 migrants feared dead as boat capsizes', Guardian Web Edition, 11 December. SMOFA (2001), Trafficking in Women and Children in Asia and Europe: A Background Presentation of the Problems Involved and the Initiatives Taken. Stockholm: Swedish Ministry of Foreign Affairs Department for Asia and the Pacific. 


\title{
3 Refugee Migration to Egypt: Settlement or Transit?
}

\author{
Mulki Al-Sharmani
}

\subsection{Introduction}

Egypt has a long history of receiving migrants of various ethnic backgrounds, such as Armenians, Greeks, Croats, Palestinians and Sudanese. Recently, the country has witnessed large scale immigration of refugees fleeing armed conflicts in the Middle East and Africa. According to UNHCR (2008) there were 23,66o Sudanese, 10, 786 Iraqis and 5,383 Somalis residing in Egypt. There were also small numbers of refugees from Eritrea, Ethiopia and other nations such as Afghanistan, Burundi, the Democratic Republic of Congo, Liberia, Rwanda, Sierra Leone, the former Yugoslavia and Yemen. In addition, there were between 50,000 and 70,000 Palestinian refugees residing in the country. By 2014, numbers rose to 183,318 refugees, including 120,000 Syrians. Many of the refugees in Egypt, though constituting the largest segment of long-term migrants, are deprived of the resources (legal, economic and social) that would enable them to establish settled communities in Egypt and pursue integration as a durable solution. For this and other reasons it is assumed that many of the refugees, notably Somalis and Sudanese, are transit migrants (Roman 2006). This chapter will first outline the migration history of the main refugee groups in Egypt, with a focus on Sudanese and Somali migrants. Second, it will analyse the policies of the Egyptian government as well as those of the UNHCR and how they have impacted on the daily lives and the future prospects of these refugees. The chapter will conclude with a discussion on the appropriateness of the term 'transit migrants' to classify these refugee groups. The analysis in this chapter draws on a review of existing literature and the findings of a field study which the author conducted on the secondary movement of Somali refugees in Egypt in 2004 (Al-Sharmani 2005). ${ }^{1}$

1 This study was part of a multi-sited research project carried out by a research team that was commissioned by the Swiss Forum for Migration and Population Studies. For the study in Egypt, a questionnaire was administered to ${ }_{16}{ }_{5}$ Somali refugees in order to investigate the scope, patterns, and causes of their movements since their flight from the homeland. Seventeen expert interviews were also conducted with key personnel at UNHCR office in Cairo, non-governmental organisations that provide services to refugees, the Refugee Department at the Ministry of 


\subsection{The history of refugee migration to Egypt}

\section{Somali refugees}

The history of the movement of Somalis to Egypt can be traced to the late 1960 s and 1970s, when limited numbers of Somali students started coming to Egypt to pursue their education at Egyptian universities, as part of bilateral educational agreements. In the 1980 s, when many Somali labourers sought employment opportunities in Gulf countries, Cairo became a popular place with Somali families who wanted to provide better educational opportunities for their children than were available in Somalia. Moving to Cairo was seen as advantageous because it would allow their children to receive a good education in a Muslim, but modern, country that was not too far either from Somalia or from the Gulf countries where the breadwinners of these families often worked. Until 1991, the largest numbers of Somalis living in Egypt were diplomats and their families, college students on government scholarships and some families and their children who were enrolled in Egyptian schools. With the collapse of the Somali government and the escalation of the civil war in 1991, Egypt saw a large influx of Somali refugees. While the majority of those early refugees came directly from Somalia, some others moved back from Gulf countries to join family members who either arrived from Somalia or were already in Cairo. The educational level of this earlier group was high and many held professional jobs; the majority had resettled in Western countries through the UNHCR.

The majority of the refugees who are currently residing in Egypt entered the country in or after 1999. Like the earlier group of refugees, this new Somali refugee group also varies in age, sex, clan affiliation and migration trajectories. While some migrated directly from Somalia, others came from Kenya, Djibouti, Ethiopia, Libya, Saudi Arabia or Yemen, or a combination of these countries. According to UNHCR data, refugees with a history of secondary movement constituted a large sector of the total Somali refugee group in late 1990s, while the majority of the current Somali refugees are direct arrivals from the homeland (UNHCR 2005). While the majority entered Egypt legally, with an entry visa that was purchased before departure with the help of family contacts in Egypt and elsewhere, a smaller number entered the country by sea, for instance those arriving from Saudi Arabia. The onward movement of refugees from first countries of asylum to Egypt was motivated by lack of legal protection and basic rights to livelihood 
and education. The educational levels of many of the more recent refugees are low compared to early groups of Somali refugees as well as Sudanese refugees (Al-Sharmani 2005; Grabska 2005). Before coming to Egypt, most did manual labour, construction work, auto-repair work or driving, and were involved in petty sales or (for women in the Gulf) in domestic work (Al-Sharmani 2005). Most Somali refugees live in overcrowded apartments which they share with other Somalis and are mainly concentrated in the neighbourhoods of Ard il Liwa and Nasr City.

It can be argued that the recent high rate of recognition of Somali refugees $\left(78\right.$ per cent $\left.{ }^{2}\right)$ has been largely the result of the use of much broader criteria in the Refugee Status Determination (RSD) process, a new policy that UNHCR Geneva called on all country offices to adopt (UNHCR 2003). According to this position paper, northern parts of the country such as Somaliland and Puntland are considered safe, while the southern sector beyond the town of Galkayo is considered unsafe. Consequently, it is assumed that refugees who are originally from the north can return to their homeland, but those from the south cannot. Nonetheless, the position paper also pointed out that if asylum seekers who come from the north have a well-founded fear of persecution in the meaning of Article 1 of the 1969 OAU Convention governing the Specific Aspects of Refugee Problems in Africa,' their claims 'should be assessed carefully on an individual basis to determine their needs for international protection.' As a result of this policy, a great number of Somali asylum seekers became recognised refugees. In addition, the UNHCR adoption of the 1969 OAU Convention as a basis for assessing RSD claims in 2003 led to an increase in the overall recognition rate as well as that of Somali refugees.

\section{Sudanese refugees}

The movement of Sudanese migrants to Egypt can be dated to the nineteenth century when Sudan was part of Egypt and was under British colonial rule. Up until the late 198 os, most of the early Sudanese who moved to Egypt were northerners and were able to take advantage of bilateral treaties between the two countries, which gave Sudanese many of the same rights as Egyptian nationals (e.g., right of employment, residence, free access to health and education, and the right to own property). ${ }^{3}$ However, after the failed assassination of President Mubarak in 1995, which implicated Islamists allegedly backed by the Sudanese government, the Egyptian 
government revoked all treaties that gave special privileges to Sudanese in Egypt. Since then, Sudanese in Egypt have been subjected to the laws governing the status and rights of foreigners.

In the late 1980s, large numbers of Sudanese refugees fled to Egypt. The majority of these recent waves of refugees were from the southern parts of Sudan, with some also coming from the north. As the number of Sudanese asylum seekers in Egypt ballooned, the Egyptian government asked the UNHCR to undertake their RSD in March 1994. Recently, Sudanese from the western part of the country have also been moving to Egypt. The estimated figures for all Sudanese residing in Egypt vary, although figures often quoted by Egyptian authorities range between two and five million. ${ }^{4}$ More than 60 per cent of these Sudanese are refugees who arrived since the late eighties.

In the period 1997-2004, 67,00o Sudanese approached the UNHCR Cairo office to apply for refugee status (Grabska 2005). Of these asylum seekers, 28,700 were recognised while 7,300 cases were pending. Also, 14,300 of the recognised Sudanese refugees in this period were resettled through the UNHCR. In addition, 20,00o Sudanese asylum seekers were rejected with 15,000 of them classified as closed files (UNHCR 2004; Grabska 2005). Until 2003, the recognition rate among Sudanese refugees was quite low because of the adoption of the 1951 Geneva Convention as the basis for successful refugee claims (Kagan 2002). Between 1999 and 2003, for instance, the recognition rate among the Sudanese was 33 per cent. But after the UNHCR's adoption of the 1969 OAU Refugee Convention as a basis for the determination of refugee claims, the recognition rate among the Sudanese rose to 63 per cent in 2004 .

Many of the refugees, particularly those from the western and southern parts of Sudan, arrived directly from the homeland. However, some of the northern refugees had first moved to the Gulf or Libya, before coming to Egypt. The main factors motivating both groups to flee include the deteriorating security situation, fear of forced conscription, religious persecution, political persecution due to political activism, pursuit of educational opportunities, as well as reunification with family members in the West through resettlement. The majority entered Egypt legally with visas purchased before departure or upon arrival, while refugees arriving before 1995 did not need a visa to enter the country. Most refugees entered Egypt either by land, taking a train to Wadi Halfa and then a steamer to Aswan, or by flying to Cairo.

4 These figures are often quoted by the spokespeople of the Egyptian Ministry of Foreign Affairs. 
The majority of the Sudanese refugees live in cramped apartments which they share with other Sudanese (and in some cases Egyptians), and are concentrated in five neighbourhoods in Cairo (Ain Shams, Arba Wa Nus, Maadi, Nasr City, and 6th October). A small number of Sudanese refugees also lives in Alexandria. The education level of Sudanese refugees is relatively high, with many having a secondary school education and some being holders of university degrees as well. The education level of the northern refugees tends to be higher than that of the southerners, while men also tend to be more educated than the women.

\section{Palestinians}

Although the history of movements of Palestinian refugees to Egypt can be traced back to 1929, large-scale immigration of Palestinians took place during the 1948 and 1967 wars. Unlike other refugee groups, the status and affairs of Palestinian refugees are directly administered by the Egyptian government instead of UNHCR. The national policies regulating the status and affairs of the Palestinian refugees have changed over the past decades. For the most part, these policies restricted the rights of Palestinians, with the exception of the period of President Nasser's rule during which Law 66 was passed. This law gave Palestinians the right to work in the public sector and to be treated as nationals of the Republic (Al-Ebed 2003). However, in 1972 this law was revoked and two administrative regulations were passed (Nos 47 and 48), which considered Palestinians in Egypt as holding the status of foreigners. This meant that they were not entitled to free education or health care and had to obtain a work permit before they could legally participate in the labour market.

Earlier waves of refugees who arrived in 1948 and after 1967 were issued a one-year residence permit and a travel document by the Egyptian government. However, refugees who left Egypt with these travel documents could not return to the country without re-entry visas, which had to have been issued before departure. The fees for renewing residence permits vary according to the arrival date of the refugee. In recent decades, the granting of residence permits to Palestinian refugees has been determined on the basis of their reason for staying in Egypt. Reasons which are considered valid include pursuing education, legal employment, marriage to an Egyptian or co-owning a business with an Egyptian national (Zohry \& Harrell-Bond 2003). Most of the current Palestinian refugees work in the informal sector and face great difficulties in obtaining affordable education. Moreover, young men who are not enrolled in school and who are not legally employed are particularly susceptible to detention and deportation. 
Unlike the Sudanese and Somalis, Palestinian refugees do not live in specific neighbourhoods or cities, but are dispersed across the Egyptian nation.

\section{Iraqis}

In 2003 and with the war in Iraq and American occupation, a large influx of Iraqis sought refuge in Egypt. The Ministry of Foreign Affairs estimates the number of Iraqis residing in Egypt to be 100,000-150,000. ${ }^{5}$ However, the number of Iraqi refugees registered with the UNHCR is 10,786. Before 2006, Iraqis arriving from Iraq were able to enter Egypt on a one-month tourist, student or investment visa. But since then, Iraqis who want to apply for an Egyptian visa are instructed by the Egyptian government to go to Syria and Jordan. Moreover, the granting of visas has become very scarce. Iraqi refugees who approach the UNHCR for refugee claims are recognised prima facia. Then, after screening, refugees who are identified as vulnerable are recommended for resettlement. In addition, there is screening for refugees who are eligible for resettlement through the Direct Access Program. ${ }^{6}$

Most of the Iraqi refugees live in Cairo, while a small number lives in Alexandria. Many of the refugees appear to come from Baghdad and are Sunni Muslims, Shi'a Muslims and Christians. Anecdotal evidence, as well as findings from interviews with some Iraqi refugees conducted by a group of journalists and researchers for the Iraqi Voices in Cairo (2008) website, suggested that most of these refugees are highly educated professionals who are often married with children.

\subsection{Egypt's policies on refugees}

Egypt was the only non-Western member of the drafting committee of the $195^{1}$ Geneva Convention relating to the Status of Refugees (and its 1967 Protocol). ${ }^{7}$ Egypt is also a State Party to the Organization of African Unity's Convention Governing the Specific Aspects of Refugee Problems in

5 In a telephone interview a staff member at the Refugee Affairs Unit at the Ministry of Foreign Affairs reported that the ministry reached this estimate on the basis of Iraqis purchasing houses, cars and businesses in Egypt (personal communication, April 2008). A 2007 Refugee International Report also estimates the number of Iraqi refugees in Egypt to be 70,0oo (Yoshikawa 2008).

6 This programme started in June 2007 as an initiative of the United States to provide protection through resettlement to Iraqis in Egypt and Jordan who were affiliated with the US forces in Iraq. This programme is administrated by IOM.

7 The 1951 Geneva Convention and its 1967 Protocol were ratified by Egypt on 22 May 1981. 
Africa, ${ }^{8}$ which expands the refugee definition contained in the 1951 Geneva Convention. Also, Article 53 of the Egyptian Constitution gives the right of asylum to political refugees. On the one hand, Egypt's commitment to these international conventions translates into fairly generous admission rights for refugees, renewable temporary residence permits, and the right of non-refoulement. On the other hand, the government does not provide refugees with the rights and resources that would enable them to build an adequate life in Egypt. This is because after the ratification of the ${ }^{1951}$ Geneva Convention, Egypt placed reservations on Articles 12 (1) (Personal Status), 20 (Rationing), 22 (1) (Public Education), 23 (Public Relief) and 24 (Labour Legislation and Social Security). In practice, these reservations imply that refugees are unable to access legal employment, free education or public health services.

For example, refugees are treated like foreigners in regulations pertaining to labour. Refugees, like all foreign nationals, are not allowed to work unless they have a work permit. To obtain a work permit, the potential employee applies to the Ministry of Manpower. Foreign applicants are not allowed to compete with the local workforce and are not allowed to work in particular sectors, such as tourism, oriental dancing, exports and customs-related jobs. ${ }^{9}$

The procedures and costs involved in obtaining work permits discourage refugees from seeking legal employment and Egyptian employers from hiring refugees, which explains why refugees tend to work in irregular jobs in the informal sector and why unemployment is high (Al-Sharmani 2003; Grabska 2005). This makes the economic conditions of most refugees very harsh. Most Sudanese and Somali refugees live in cramped apartment buildings in the poor neighbourhoods of the city. The apartments are generally shared with other co-ethnic refugee families. Moreover, because they are foreigners, Sudanese and Somali tenants pay much higher rents than poor Egyptians (Al-Sharmani 2003; Minnick \& Nashaat 2009).

Refugee children are not entitled to free education in public schools, while private schools are generally too expensive for refugee populations. In 1992, the minister of education issued Decree No. 24, which gave the legal right to Sudanese, Jordanian and Libyan children to access primary education at state-owned schools. In 2000, this right was extended to other refugee children. Nevertheless, Decree No. 24 is not implemented on a large-

8 Egypt ratified the 1969 OAU Convention on 12 June 1981.

9 Foreign applicants from particular nationalities are exempted from paying the application fees, such as Sudanese working in the private sector; Palestinians and Italians who had been in the country for five years or more; and Greeks. 
scale basis as a consequence of ineffective coordination and communication within and between relevant ministries. For instance, in my interview with a senior specialist at the Department of Foreign Students at the Ministry of Education, he said that he was not aware of any ministerial decrees that allow children of refugees or asylum seekers to attend free public schools. In fact, according to him, there was no distinction between refugees and foreign nationals in the procedures and the regulations that both groups had to follow in order to enrol their children in Egyptian schools..$^{10}$

Therefore, to enrol their children in schools, the parents of all foreign children (refugees and non-refugees) need to submit academic records and proof of residence in Egypt (e.g., a refugee card) to the school and Department of Foreign Students and have to pay tuition fees. Parents also need to fill out security clearance forms which the Department of Foreign Students sends to the National Security Office for review and approval.

It seems that the challenges of implementing Decree No. 24 do not merely arise from lack of effective communication and coordination within government bodies. Another important factor is the unpopularity of public schools because of the low quality of the education they offer. Most of the public schools are crammed with students and lack adequate teaching staff and educational resources. There is also a perception among some of the refugees as well as NGOs and government bodies that refugees do not want to enrol in public schools because they do not think these schools prepare their children for life in the West, where the majority of the refugees want to resettle. ${ }^{11}$ In short, refugees' access to public schools remains very limited. Very few refugee families manage to enrol their children in private schools. Many Sudanese and Somali refugees resort to other alternatives such as church-run and refugee-run schools. Some refugee families (mostly Somalis) also enrol their children in Al-Azhar-run schools. ${ }^{12}$

The ministries of Foreign Affairs and Interior Affairs are the two main governmental entities with which the UNHCR Cairo office coordinates closely in order to ensure the protection of refugees and the management of their affairs. Both ministries deal mostly with issues related to refugees'

10 Interview with Senior Specialist at the Department of Foreign Students at the Ministry of Education, 12 March 2005.

11 This opinion was expressed to me repeatedly by staff members at different NGOs that work with refugees, such as Caritas, and Africa Middle East Refugee Assistance (AMERA), as well as by some of the Somali refugees (Al-Sharmani 2003, 2005; Grabska 2005).

12 These are primary through secondary schools that are run by the Al-Azhar academic institution. Such schools teach students both regular school subjects and more extensive religious education. 
residence permits and detention cases. For instance, any asylum seeker or refugee who wishes to apply for a residence permit goes to the Department of Refugee Affairs at the Ministry of Foreign Affairs. The Department of Refugee Affairs, furthermore, acts as the main government body that the UNHCR, NGO, and refugee communities communicate with for advocacy work. Nonetheless, it is the UNHCR, rather than the Egyptian government, that predominately deals with refugees in the management of their affairs. Due to a lack of adequate capacities and institutional resources for the process of handling the asylum procedures, the Egyptian government has delegated this task to the UNHCR Cairo office. Thus, registration of refugees, refugee status determination interviews, durable solution interviews and all other asylum-related procedures are carried out by the UNHCR Cairo office. Also in cases where asylum seekers and refugees are detained, the UNHCR liaises with both departments so that they can be released.

In an interview, the Head of the Department of Refugee Affairs at the Ministry of Foreign Affairs explained that the government was committed to protecting refugees because Egypt is a signatory to international conventions pertaining to Somali and Sudanese refugees. However, she also stressed that 'real integration' was not possible for the refugees and that their stay in Egypt was a 'transitory phase':

We have put reservations on the $195^{1}$ Geneva Convention, which is understandable. We do not have enough resources to offer education and other services to all nationals. So it is not possible for us to make that commitment to refugees. So refugees are not allowed to enrol in free public schools. But we [this office] try to help refugees who need education on an individual case basis. We are also working on an agreement with European NGOs and the EU to build schools that will offer education to both Egyptian and refugee children. Refugees' time in Egypt is a transitory but an important phase ... Refugees have to obtain a work permit before they can work. They have to go through the same procedures for obtaining a work permit that foreigners do. But many refugees manage to work in the tertiary sector like many Egyptians do (interview with Head of the Department of Refugee Affairs at the Ministry of Foreign Affairs, 17 February 2005).

This notion that the issue of refugees and their time in Egypt is temporary is reflected in the state's lack of comprehensive national policy that regulates all refugee affairs. Instead, on occasions the government resorts to fragmented and ineffective policy solutions, such as ministerial decrees, 
to address some of the pressing needs of refugees. The vulnerable situation of refugees in Egypt is also reinforced by their ineligibility for Egyptian citizenship regardless of the length of their residency. This undermines the refugees' opportunities for integration into Egyptian society. Because of their economic, social, and legal marginalisation, refugees lead harsh and precarious lives. This explains, to a large extent, why most refugees in Egypt seek resettlement as the durable solution for their situation. It also explains why refugees have a lot of expectations (often unrealistic) from the UNHCR office, the institution that handles their asylum procedures, including their resettlement.

\subsection{UNHCR Cairo: Protection policies}

Since the late 199os, the UNHCR Cairo office has seen an enormous increase in the number of asylum seekers. For example, the number of asylum seekers doubled from 1998 to 1999. In 2001, the number of asylum seekers was 13,176, which was a 96 per cent increase from 1998 (UNHCR 2002; see also Kagan 2002). In fact, the number of asylum seekers in 2002 was almost double the number of asylum seekers in the UNHCR Kenya office (UNHCR 2001; see also Kagan 2002). In particular, the number of Iraqis who are seeking asylum in Egypt continues to increase, currently constituting 25 per cent of the caseload at the UNHCR Cairo office (UNHCR 2008). By 2014, there were 18,307 asylum seekers. The increase in the number of asylum seekers coming to Egypt can be explained by a combination of factors. First, most of the asylum seekers come from countries with continuing armed conflicts and instability. Second, the UNHCR-assisted resettlement programme attracts many refugees who feel that a safe and stable life is neither possible in their countries of origin nor in neighbouring host societies in Africa or the Middle East. A third factor, which has not been fully examined, is the transnational family network of which more and more refugees are becoming part. That is, the efforts and desires of individual refugees to migrate and to ultimately resettle in the West are part and parcel of collective family-based strategies to ensure survival and a stable life for different family members (Al-Sharmani 2004).

Asylum seekers who wish to file a refugee claim go through the following procedures: they approach the UNHCR office and fill out an application form. The applicant is given a registration date, which can be two to three months after the submission of the application. After the registration interview the applicant is given either a yellow card or an asylum seeker 
letter with a refugee determination status (RSD) interview date. The RSD interview is often conducted within two to six months, depending on staffing capacities. The waiting period for a decision is one to four months. The process is not the same for all refugees. For instance, asylum seekers who are recognised as prima facia, such as Iraqis, do not go through an RSD interview.

Asylum seekers with yellow cards are eligible for a six month residence permit. This temporary residence permit is renewable up to three times. After the RSD interview, asylum seekers who are recognised receive blue cards from the office and are eligible for a one year renewable residence permit. Residence permits issued to asylum seekers and recognised refugees are stamped on the yellow or blue card. Also the passport of the asylum seeker or refugee is voided by the Department of Residence and Immigration once the applicant receives the residence permit.

Individual refugee claims (apart from those recognised as prima facia) are recognised either on the basis of the $195^{1}$ Geneva Convention or on the basis of the 1969 OAU Refugee Convention. Both kinds of refugees are entitled to annual residence permits and protection from detention and deportation. Also vulnerable individuals and families, regardless of their status as 1951 or 1969 OAU refugees, are entitled to limited forms of financial assistance, health care, and educational grants. The main distinction, however, between the two kinds of refugees is that those who are recognised on the basis of the 1969 OAU Refugee Convention are not eligible for resettlement, since Western countries are not signatories to the convention. The exception to this has been vulnerable groups among the 1969 OAU refugees, such as 'women at risk'.

Asylum seekers who are recognised as 1951 Geneva Convention refugees go through a durable solution interview with an UNHCR official. The three options that are considered in such interviews, depending on the circumstances of each refugee claim, are local integration, voluntary repatriation, or resettlement. Understandably, voluntary repatriation has not been possible for the Sudanese and Somali refugees because of the armed conflicts in their countries of origin. This, however, may no longer be the case for Sudanese refugees, because of the recent peace agreement between the Sudanese government and the rebel groups in the south as well as the four freedom agreements between Egypt and Sudan. ${ }^{13}$

13 According to the UNHCR Fact Sheet-Egypt of February 2008, 184 Sudanese were voluntarily repatriated in the period January-February 2008. 
Resettlement is considered a durable solution for refugees who meet the resettlement criteria as outlined in the UNHCR Resettlement Handbook. The underlying premise of these criteria is that the refugee continues to be in a precarious and vulnerable condition in the first country of asylum for a variety of reasons and can only obtain protection and a durable solution through resettlement. The main resettlement criteria are 1) the refugee and/ or his or her family do not find legal and physical protection in the first country of asylum, 2) the refugee is a survivor of violence and torture and requires specific medical attention that is not available in the first country of asylum, 3) the refugee has certain medical needs or disabilities and lacks the mechanisms to lead a viable life in the first country of asylum, 4) the refugee is a 'woman at risk' who faced torture and violence in the country of origin and continues to be at risk in the first country of asylum for a variety of reasons that may be related to the situation in the country of origin as well as in the host country and 5) the refugee lives in a precarious security situation or harsh economic conditions in the first country of asylum. The resettlement programme in Egypt is one of the main attractions that motivate refugees to come to Cairo. Still, resettlement, unlike protection from refoulement and voluntary repatriation, is not a guaranteed right for the refugee. Moreover, as a durable solution, resettlement is a process that is determined to a large extent by the regulations and quotas set by receiving countries.

Asylum seekers who are rejected are eligible to appeal against the decision within one month and a committee at the UNHCR office reviews the appeal cases and makes decisions. If an appeal is rejected, the file of the asylum seeker is closed; hence the individual is no longer under the protection of the UNHCR and can be legally deported. This, however, rarely happens in reality. On the other hand, rejected asylum seekers face the drawbacks of staying in the country without the protection of the UNHCR, which include arbitrary detention and the inability to access the few services that are made available to the refugees by the UNHCR and refugee aid organisations.

The UNHCR ensures the protection of all kinds of refugees and asylum seekers from detention and deportation. While the detention of refugees and asylum seekers is not a regular and wide-scale problem in Egypt, it does take place. In such cases, the role of the UNHCR is to confirm the status of the detainee so that he or she can be released. However, the mechanism in place for this process is sometimes inefficient (Helal 2004). When a refugee or asylum seeker is detained, the UNHCR is supposed to receive a letter from the Egyptian Immigration Department requesting confirmation of the status of the refugee. But in many cases, the UNHCR staff members are 
informed of the detention of refugees through unofficial means (i.e., the detainee's family members or neighbours). The UNHCR sends a letter to the Immigration Department verifying the status of the detainee. When the Egyptian authorities are reassured that the refugee in detention is under the protection of the UNHCR, he or she is released. This process frequently lasts fourteen days, but can also take longer. Moreover, the physical conditions in detention centres are cruel. Detainees complain of harsh treatment and in some cases they are allegedly extorted for bribes by detention officers. Thus, on the one hand the legal protection that refugees and asylum seekers are granted is meaningful and beneficial because it allows them to reside in the country in relative safety. On the other hand, it has its limitations because of certain gaps in coordination and cooperation between the UNHCR and the relevant Egyptian institutions in this aspect.

To assist refugees with sustenance and access to some educational and health services, the UNHCR office offers recognised refugees and asylum seekers several forms of assistance through partnership with a number of NGOs. First, vulnerable refugees such as those with children, unaccompanied minors, disabled and chronically ill refugees receive monthly financial assistance that ranges between $\mathrm{EP} 200$ and $\mathrm{EP} 600 .{ }^{14} \mathrm{Financial}$ assistance is dispensed through the Caritas Office in Cairo and eligible refugees collect the money from one of the branches of the Bank of Alexandria every two months. The UNHCR also gives educational grants that range from EP 700 to 1,400 to 6-15 year old children of recognised refugees and asylum seekers. The grants are dispensed through the Catholic ReliefService Office and are paid in two instalments. Also other UNHCR partner organisations, such as the Joint Relief Ministry at All Saints Cathedral, offer counselling, support, and medical assistance for pregnant women, victims of torture, and refugees with tuberculosis. Recognised refugees can also access health care at a Caritas clinic which is run by two doctors. The UNHCR office (through Caritas) pays 50 per cent of the costs of the medication. Furthermore, the Refugee Programmes at Saint Andrews and All Saints Cathedral offer education to children who are excluded from Egyptian schools. The UNHCR also supports the 'Care with Love' (CWL) NGO that offers on-the-job vocational training to refugees.

Nevertheless, the different forms of assistance that refugees receive from the UNHCR are insufficient. This is because, while the number of refugees in Egypt has been increasing, the allocated budget to the UNHCR Cairo office has been dwindling (Sperl 2001). The sharp decrease in financial 
resources and the subsequent understaffing resulted in a backlog of RSD cases. Also, single refugees and those without children complain that they do not receive financial assistance although they, like refugees with children, are not employed. Some of those who receive financial assistance or educational grants complain of several problems that they encounter in the process of collecting the money. Sometimes, monthly financial assistance is delayed or suspended. Educational grants are not sufficient to cover school fees. Moreover, the grants are only dispensed to refugees after they submit receipts verifying that they had paid school fees. But parents point out that they often do not have the money to pay the fees in the first place and in some cases the delay of reimbursement has resulted in dismissal of children from schools (Al-Sharmani 2003). Moreover, many refugees also complain about inadequate health services at the Caritas clinic and lament that there are too few physicians overwhelmed with large numbers of patients and that quality of health care is low. In fact, the inadequate financial and staffing resources of the office and the large number of asylum cases that it is handling have resulted in tensions between refugee groups and the office. On several occasions, Somali and Sudanese refugees have protested (separately) in front of the UNHCR office to voice their concerns and frustrations.

In response, UNHCR officials have been negotiating with the Egyptian government to widen the legal rights and institutional support that are available for refugees. One outcome of this was the procedure of issuing yellow cards to asylum seekers and granting them six month residence permits. This procedure, which was first implemented in December 2002, was part of an effort to deal with the problem of detention of asylum seekers. Another achievement was the Ministerial Decree No. 24 that was issued by the Ministry of Education in 1992 and the Decision of the Minister in 2000 to allow refugee children to have access to public schools. Also the UNHCR and the Catholic Service have been working on establishing a system which will relieve parents from the burden of paying school fees in advance by finding ways in which the Catholic Relief Service can pay the schools directly. Furthermore, the UNHCR office has been involved in efforts to work with refugee associations and to support community-based efforts to address the needs of refugees. Despite these on-going efforts, the living conditions of most refugees remain very difficult and UNHCR staff members as well as different NGOs working with refugees concur that the self-sufficiency of refugees and their integration into Egyptian society have been very challenging goals to achieve. The head of the Refugee Centre for Human Rights, an Egyptian NGO that offers legal aid to refugees and 
helps them to access Egyptian court systems for documentation purposes, explained the limitations of the situation of the refugees in Egypt and the kind of protection they receive from the UNHCR as follows:

To determine whether the UNHCR is providing protection, we have to agree, first, on what protection means. If protection means giving refugees blue cards and protecting them from detention, then the answer is yes. The UNHCR is providing protection. If protection also means providing a humane life for refugees, then the UNHCR has failed (interview, Head of Refugee Centre for Human Rights, 15 March 2005).

For this Egyptian lawyer, overcoming the problems that refugees face in Egypt, and providing comprehensive and multi-layered protection, requires that the Egyptian government plays a central role in refugee affairs and that Western governments provide financial support to a much needed national integration programme. She said:

Refugees need to find an adequate life in host societies. The Egyptian government needs to help the refugee community access health and education services not on individual but on community bases. There needs to be a real policy for integration. But realistically in order for that to happen, Western countries must provide financial assistance to the Egyptian government because it lacks sufficient resources. There needs to be better coordination between top policymakers and junior government employees that implement these policies. For example, it is not enough for the government to decide that refugee children can now access public schools. There needs to be training of school staff so that they are ready and able to teach and handle classes that include refugee and Egyptian children and can encourage good interactions between refugee students and Egyptian ones.

When I asked the assistant representative of the UNHCR office in Cairo about the possibility of local integration for refugees in Egypt, he pointed out that it was difficult to talk about integration in a developing country (interview, February 2005). He explained that perhaps it was more realistic to aim for self-sufficiency in this case. Yet, he admitted that even selfsufficiency was difficult to achieve. Refugees are concentrated in poor urban areas where accommodation is expensive and employment is very difficult to find. Moreover, he agreed that the assistance that was provided to refugees by the UNHCR and partner organisations was limited. 
However, is the situation of refugees worse than that of poor Egyptians, who also have problems finding employment, who live in poor urban neighbourhoods and slum areas where housing and living conditions are harsh, who may also suffer from human rights violations by law enforcement institutions, for example as a consequence of the Emergency Law introduced in 1981? The answer is complex. On the one hand, the living conditions of refugees are further worsened by their precarious legal status. Landlords charge them more rent. Their refugee cards sometimes do not ensure their protection from police officers who still take them to detention centres and keep them in custody until the UNHCR intervenes. On the other hand, poor Egyptians, unlike refugees, lack a legal framework of international laws and conventions that advocate their protection, as the Head of the Department of Refugee Affairs at the Ministry of Foreign Affairs argues:

I think Somali and Sudanese refugees are doing much better [than poor Egyptians]. Refugees have the protection of the UNHCR. They have refugee advocates, the UNHCR and our office is working for them and trying to protect them. Poor Egyptians have Allah. Refugees may be resettled, but what will Egyptians do if they cannot find the basic needs for life right here in their country? Also police officers do not detain foreigners and refugees only. Egyptians are subject to that and it happens a lot that Egyptians also get detained if they are not carrying their personal IDs. Often when these officers detain someone, they do it because they are trying to do their job. They are in some public place and they see someone they are not sure about and who happens not to have documents to prove his identity and residence status, so they detain them. It happens to Egyptians too. But we make sure that when refugees are detained they are released as soon as possible. And we offer this protection to recognised refugees as well as asylum seekers (interview, Head of Department of Refugee Affairs at the Ministry of Foreign Affairs, 17 February 2005).

Moreover, the depictions of refugees in the mass media convey contradictory messages and images. Sometimes, refugees are portrayed as a national threat. Other times they are portrayed as people who need protection and Egypt's duties as a host society are asserted. For instance, the title of one of the main featured articles in the weekly Rosa el Yusuf in 2003 was 'The Floods of Africans and Asians are Snatching Livelihood from Our Youth' (Subhi \& Abdel-Gawad 2003). The article mentioned the danger of the increasing number of African and Asian migrants who would be 'stealing' employment opportunities from Egyptian youths by working as 
street vendors. The article also depicted the migrants as sources of social problems such as drugs and prostitution that were, according to the article, becoming prevalent in Egypt. Needless to say, the language of the article was highly inflammatory and prejudiced. There was no mention in the article of the refugee status of the 'African migrants' nor or of Egypt's obligations towards them as a signatory of international conventions on refugee rights. Moreover, in letters to the editor published in the daily Al-Ahram in the same year, Egyptian readers raised the issue of the threats that refugees pose to Egyptian society because of their alleged loose moral values, again related to alleged drug use and illicit sexual relations.

On the other hand, newspapers and TV programmes also feature refugee assistance efforts that are led by UNHCR Goodwill Ambassadors such as the famous Egyptian actor Adel Imam. Such media reports do not highlight the perceived problems posed by refugees but the generosity of Egyptian society for providing protection to them.

\subsection{Refugees' experiences}

\section{Getting by in Egypt}

Family and community-based support systems are the main strategies that many refugees use to survive on a daily basis. Refugees depend on one another to share information about housing, UNHCR news, residence permits, detention problems, and other aspects related to their lives in Egypt. The refugees are all concentrated in Cairo, in neighbourhoods populated by other co-ethnic refugees. They share apartments with other family members or refugees whom they have befriended in Cairo or have known in previous host societies. Most live on a combination of limited sources of income. These sources are often: remittances from family members living in the West or Gulf countries, financial assistance received from the UNHCR, or small and highly irregular income from intermittent work in the informal market. There are problems with all. First, while remittances are a main source of sustenance money, they are sometimes irregular, especially in cases when remitting family members lose their jobs, or discontinue remitting to attend to another family member who has more serious need, or where a family conflict has occurred. Second, only vulnerable refugees such as single parents with children, disabled individuals or unaccompanied minors receive financial assistance from the UNHCR. As previously mentioned, this assistance is meagre. Moreover, there have been reports by numerous refugees who are eligible for such assistance that they often 
encounter problems in collecting the money, such as delays in disbursing the money or sudden and unexplained suspension of monthly allowances.

Third, the kind of wage-paying work that refugees undertake is irregular, poorly paid, and with no legal benefits or labour protection. Sudanese male refugees are mostly employed as construction labourers, factory workers, office cleaners, and security guards (Grabska 2005). Compared to the men, Sudanese refugee women find more job opportunities, with higher wages, in the domestic work market. Some of the women also earn income from petty sales and crafts. The average salary earned by Sudanese refugees ranges from EP 250-350 for males to EP 400-6oo for females (Grabska 2005).

Unlike Sudanese refugees, Somalis engage in income-generating activities that are mostly confined to Somali communities. Women work as domestic workers for Somali émigrés who have relocated from various Western countries. Some women also work for Egyptian families. Somali domestic workers make between EP 400 and EP 600 when they work for Egyptian families and $\$ 100-\$ 150$ when they work for Somali émigrés. Some of the women also generate income by selling home-made Somali food to Somali émigrés on special occasions such as weddings and religious gatherings. Such female vendors make the equivalent of EP 200 to EP 300 a month. Also, some male refugees teach Quran, Arabic and Somali to Somali refugee children as well as the children of the émigré families and earn between EP 120 and EP 400. The scope and prevalence of these different kinds of income-generating activities are fairly small because potential employers (i.e., émigré families) are still not that numerous when compared to the size of the Somali refugee population..$^{5}$

In recent years, however, a number of Egyptian telecommunication businesses (internet cafes and telephone offices) which cater for mostly Sudanese and Somali refugees have been hiring individuals from these refugee groups (Al-Sharmani 2003; Grabska 2005). The number of refugees hired by such businesses is very small and thus far all employees have been male. But it remains to be seen (and studied) to what extent this phenomenon will become prevalent and what its impact will be on the livelihood of the refugees. In addition, other spaces for societal member-

15 There are no official figures on the number of Somali émigrés who relocate to Egypt from the West. During my doctorate research in the period 2001-2003, I calculated that there were about 200 Somali émigré families in Egypt. But my research and informal observations that I have carried out since then suggest that increasingly more émigrés are relocating from North America and Europe to Egypt in order to purchase homes, educate their children in Egyptian private schools, pursue religious education, and engage in trading activities. However, these émigré families maintain a transnational life, going back and forth. 
ship are slowly being opened for refugees as a result of intensive advocacy/ research work that has been carried out by local research institutions, the UNHCR, its implementing partners and other activists. This is reflected in the recent participation of Egyptian opposition movements (such as Kifaya) in advocacy work on the behalf of refugees. ${ }^{16}$ Also a number of Egyptian NGOs (e.g., the Coptic Evangelical Society), which in the past were solely concerned with Egyptian communities, are now taking part in development programmes that target refugees.

Despite these new spaces of cooperation, and positive interactions between some sectors of Egyptian society and refugees, the lives of most refugees continue to be characterised by a high degree of economic vulnerability, difficult living conditions exemplified by poor and cramped housing, limited educational opportunities and precarious legal protection which does not lead to long-term security and stability. Under such conditions, resettlement in the West becomes highly desirable to the refugees as it is seen as a way to access legal employment, adequate health care, educational services and Western citizenship (which is perceived as a form of capital).

\section{Resettlement and protection: Are they related?}

Most refugees seek resettlement through the UNHCR. But while the number of recognised refugees has recently increased, the same has not been true of those who are resettled. Thus, UNHCR-assisted resettlement can only be offered to a small number of refugees. Accordingly, some of the refugees who are found not eligible for resettlement or have despaired of waiting have resorted to other means to achieve this goal. Sudanese refugees, for instance, actively pursue resettlement by applying to the Australian sponsorship programme. Some of these refugees are able to meet the requirements of this programme with the assistance of family relatives in Australia, while others obtain assistance from churches in Egypt in order to complete the requirements of the application process. In addition, between 2002 and 2003 several hundred Somali refugees attempted to travel to Europe through Libya, like Syrians are now doing. Many of the refugees travelled to Niger by air and then entered Libya by land, and from there took small boats that were overloaded with refugees. Some lost their lives on these harrowing journeys, yet some made it to Italian shores, keeping similar hopes alive for those left behind in Egypt.

16 For example, Kifaya members participated in the protests that were organised by the Sudanese refugees in 2005 and were very critical of the violent break up of the protest by Egyptian security forces. 
The importance (perhaps even the necessity) of resettlement is ever more real for Somali refugees who moved and settled in different host societies such as Kenya, Libya and Saudi Arabia, where they encountered inadequate protection and deprivation from basic rights and resources to secure livelihood and education. Many of these refugees repeatedly talk about the inseparability of protection and the possibility of having a life with long-term legal stability, employment possibilities and a sense of a future (Al-Sharmani 2005).

This search for safety and stability through onward movements often forms part of the collective needs, wishes and struggles in which several family members participate, in different ways. That is, refugees move to seek safety and stability not only for themselves but also for a transnational circle of inter-linked family members (Horst 2006). For instance, a Somali man who fled his homeland in the civil war ended up in Saudi Arabia. He is working irregularly but manages to remit money to his extended family in the homeland. The family used the money to send his niece to Egypt so that she can be safe from the danger of rape and sexual violence that women have been confronting since the start of the civil war. Meanwhile the niece has found a job as a domestic worker and is supporting a widowed aunt and her children who are also living in Egypt. The aunt and children await resettlement so that they can secure more adequate protection and resources that will in turn enable them to participate in the transnational familial efforts to secure the safety and well-being of other family members.

Yet, the struggle and the pains of resettlement are not only related to the question of how to secure it and the price that people sometimes pay in the process. There are also the psychological and physical pains that refugees associate with the yearning for resettlement, which Somali refugees call Buufis (Horst 2006).

In short, the protection of refugees cannot be divorced from opportunities for their economic self-sustenance and social development. Similarly, the availability of economic opportunities for refugees without legal rights is an inadequate mechanism for pursuing protection and wellbeing. That is, adequate refugee protection is multi-layered. It starts with well-defined legal rights but it is also contingent on an environment in which refugees are enabled (institutionally, economically and socially) to sustain themselves, secure their well-being and become full members of the host society. Thus, the initial movements of Sudanese and Somali refugees from their homeland, the onward movement of some of them from other countries to Egypt, their yearning for and/or the pursuit of movement from Egypt to the West need to be understood as an intrinsic part of a complex and dynamic process of seeking adequate protection and well-being. 


\subsection{Conclusion: Settlement or transit?}

In a 2006 report on transit migration in Egypt, Roman (2006) categorises the Somali and Sudanese refugees as transit migrants. The author bases her classification primarily on the basis of the refugees' wish for and (in some cases) pursuit of resettlement in the West. In an article that re-examines the political genealogy and academic use of the term 'transit migration' Düvell (2006) takes Roman and other authors to task by arguing that their uncritical use of the term 'transit migrant' creates a lot of confusion. For instance, Roman classifies Sudanese and Somali refugees as transit migrants although a considerable number of these refugees have lived in the country for a decade or more; few of them actually resettle in the West and we do not know (at least from Roman's study) about the further movements and outcomes of Sudanese and Somali refugees who resettled in the West.

Düvell traces the conceptual ambiguity surrounding the term 'transit migration' to political discourses in which the term was first used in the nineties. He points out that in the discourses of the IOM, UN and EU, the term is used in multiple and inconsistent ways, all of which reflect a tone of perceived threat that is associated with this kind of migration. In these discourses, transit migrants are more or less conceived of as those who are passing through or staying in a country for a temporary period of time while planning to move to another destination. In addition, transit migration is often coupled with issues of irregular movements and trafficking.

This highlights two important issues that are perhaps not well-examined in studies of transit migration. For one thing, the people often referred to as transit migrants engage in complex and dynamic processes of decisionmaking and strategising, regarding the trajectories of their movements and their purposes. This process is shaped by multiple and often changing factors. In the case of refugees, such factors include the kind and quality of protection that they need and are able to access in different asylum countries; their family-based needs and strategies for securing protection and well-being; refugee policies of asylum countries from which refugees have moved or where they or their families are currently staying; and the availability of resources that enable movement to particular countries. These resources include legal and social capital, economic means, migratory experiences and facilitating networks, etc. Thus, the multiple movements of some Somali and Sudanese refugees to other countries in Africa and the Middle East and then to Egypt, and their pursuit of resettlement in the West, exemplify the above-mentioned process of decision-making and strategising. 
Second, the existing conceptualisations of transit migration conceal the connections between this kind and other types of movement. The Somali émigrés in Egypt are a case in point: many were refugees in the Middle East and Africa, resettled in the West and obtained citizenship. But in the past seven years, it has been observed that some of these North American and European Somalis have also been relocating to Egypt, thus their movement to Egypt turns out to be circular. Their motivations are multiple and tend to consist of the desire to escape cultural and socioeconomic marginalisation in Western societies, to invest in interdependent relationships of maintenance and care with family members who are in the homeland or in neighbouring countries, and to use the newly acquired capital of Western citizenship and educational skills to pursue an empowering, albeit transnational, life (Al-Sharmani 2004). There are links between Somali refugees' pursuit of resettlement in the West and the relocation of Somalis with Western citizenship to Egypt. Both groups of Somalis are often part of transnational families whose members are collectively engaged in interdependent relations of care and support. In addition, the movements of both groups seem to be different parts of a similar endeavour, which is seeking a life of adequate protection and empowerment.

In brief, the term 'transit migrant' fails to capture important aspects of migratory experiences of refugees in Egypt. However, host societies' policies towards refugees are an important factor shaping the (both political and academic) discourses on transit migration and do have a certain impact on refugees' experiences. In the case of Egypt, the government's policies and national discourses have generally treated and portrayed the presence of refugees as transitory. These policies and discourses have influenced refugees' sense of the temporary nature of their dwelling in the country, even if they have been staying for more than a decade. Thus, in our efforts to improve our understanding of transit migration, we also need to be aware of how the issue is framed differently by those who move and by the societies that receive them.

\section{References}

Al-Ebed, O. (2003), Palestinian Refugees in Egypt: Executive Summary. Working Paper Series: Forced Migration and Refugee Studies Program. Cairo: American University.

Al-Sharmani, M. (2003), The Livelihood and Identity Constructions of Somali Refugees in Cairo. Working Paper Series: Forced Migration and Refugee Studies. Cairo: American University. Al-Sharmani, M. (2004), Refugees and Citizens: The Somali Diaspora in Cairo. Doctorate dissertation, Department of Anthropology. Baltimore, MD: Johns Hopkins University. 
Al-Sharmani, M. (2005), The Secondary Movement of Somali Refugees in Egypt and State Policies. Research Study. Neuchâtel: Swiss Forum for Migration and Population Studies.

Cassarino, J.P. \& P. Fargues (2006), 'Policy responses in MENA countries of transit for migrants: An analytical framework for policymaking', in N. N. Sørensen (ed.), Mediterranean Transit Migration. Copenhagen: Danish Institute for International Studies, 101-108.

Düvell, F. (2006), Crossing the Fringes of Europe: Transit Migration in the EU's Neighbourhood. Working Paper No. 33. Oxford: Centre on Migration, Policy and Society.

Grabska, K. (2005), Living on the Margins: The Analysis of Livelihood Strategies of Rejected Sudanese Refugees in Egypt. Working Paper Series: The Forced Migration and Refugee Studies. Cairo: American University.

Helal, H. (2004), 'What are the laws governing refugees and detention of migrants in Egypt?' Unpublished paper. Cairo: AMERA Office.

Horst, C. (2006), Transnational Nomads: How Somalis Cope with Refugee Life in the Dadaab Camps of Kenya. New York and Oxford: Berghahn Books.

Iraqi Voices in Cairo (2008), Accessed March 2008, http://aucegypt.edu/ResearchatAUC/fmrs/ iraqivoicesincairo/Pages/About.aspx.

Kagan, M. (2002), Assessment of Refugee Status Determination at UNHCR's Cairo Office 2001-2002. Working Paper Series: The Forced Migration and Refugee Studies. Cairo: American University.

Minnick, E. \& N. Nashaat (2009), 'Stuck in Egypt': Iraqi refugees' perceptions of their resettlement to third countries and return to Iraq. Unpublished report, Center for Migration and Refugee Studies, American University in Cairo.

Papadopoulou, A. (2005), Exploring the Asylum-Migration Nexus: A Case Study of Transit Migrants in Europe. Global Migration Perspectives No. 23. Geneva: Global Commission on International Migration.

Refugees International (2007), Egypt:Respond to the Needs ofIraqi Refugees, 12 April. Washington, DC: Refugees International.

Roman, H. (2006), Transit Migration in Egypt. CARIM Research Report No. 1. Florence: European University Institute.

Sperl, S. (2001), Evaluation of UNHCR's Policy on Refuges in Urban Areas: A Case Study Review of Cairo. Geneva, Switzerland: United Nations High Commissioner for Refugees, Evaluation and Policy Analysis Unit.

Subhi, K. \& E. Abdel-Gawad (2003), 'Floods of Africans and Asians: They are snatching livelihoods from our youth', Rosa al Yusif 3892.

UNHCR (2001), Statistical Overview 2001. Geneva: UNHCR.

UNHCR (2002), Statistical Report 2002. Cairo: UNHCR.

UNHCR (2003), UNHCR Position on the Return of Rejected Somali Asylum Seekers to Somalia. Position Paper. Geneva: UNHCR.

UNHCR (2004), Self-Reliance Survey. Cairo: UNHCR.

UNHCR (2005), UNHCR Country Operations Plan: Egypt. Cairo: UNHCR.

UNHCR (2008), Fact Sheet - Egypt, 28 February. Cairo: UNHCR.

Yoshikawa, L. (2008), 'Iraqi Refugees in Egypt', Forced Migration Review 29, accessed 27 March, www.fmreview.org/FMRpdfs/FMR29/54.pdf.

Zohry, A. \& B. Harrell-Bond (2003), Contemporary Egyptian Migration: An Overview of Voluntary and Forced Migration. Development Research Centre Working Paper C3. Brighton: University of Sussex. 



\section{Transnational Migration}

The Case of Sub-Saharan Transmigrants Stopping Over in Morocco

\section{Mehdi Alioua}

Life is a caravanserai

It has two doors

I entered through one

I left through the other

(Sufi proverb)

Since the generalisation of the visa regime across the Schengen area in the 1990 s, followed by the restrictions on issuing visas which now stand in the way of the majority of Africans wishing to migrate to Europe, staged transnational migration has become one solution for African migrants, opening or reopening new migratory routes from sub-Saharan Africa, through the Maghreb, to Europe. In this chapter, this phenomenon is referred to as 'transmigration', as explained and justified below. So, thousands of subSaharan transmigrants enter and relocate themselves collectively every year in the Maghreb, setting up stopovers which, since their establishment in the 1990s, have continued to serve as migratory staging posts for newcomers: these stopovers have a social history which has gradually become a part of migratory trajectories. This study of the sub-Saharan transmigrants' transnational networks therefore asks how we should see the creation of the unrestricted spatial configurations produced by these moving populations, within a geopolitical context where the borders are not as porous as the term 'transnational' would suggest. In response to this, the notion of a stopover, seen simultaneously as an observation location, a methodological framework and an analytical tool, seems much more relevant than the notion of 'transit', which is too restrictive from a space-time point of view. This chapter develops and illustrates this idea, working from the example of Moroccan stopovers in the transmigration of sub-Saharan Africans. 


\subsection{The stage: The best place to observe and understand 'transit migrations'}

Since the 1980s, a number of social scientists have identified new concepts associated with changing aspects of the international migration experience, including 'circulatory territory', " 'migratory circulation'” or 'transnationalism', with the resulting notions of 'transnational migration' and 'transmigrants' (Glick-Schiller, Bash \& Szanton Blanc 1995). All these terms have been developed to give a better description of the processes through which migrants create social spaces which extend across geographical, national and political borders. Migrants, whatever status is assigned to them or identity they claim for themselves, are implicated in establishing relationships between different places: they connect territories, construct multiple networks, encourage the circulation of goods and services (Tarrius 2002), ideas and images (Appadurai 2005) and carry with them a whole world of relationships and social networks that support them. When borders are closed to them, the nature of the flows changes: new forms of displacement appear and change the migratory space, simultaneously enlarging it. At the same time, former emigration countries become immigration spaces, and vice versa. In the face of this constant flux, the traditional distinctions between emigration countries and immigration countries, between work migration and multiple displacements, between lasting migration and temporary migration, are no longer adequate to describe the changes taking place.

This research, focusing on the distinct, often individual, migration projects of sub-Saharan African migrants in Morocco, draws its inspiration from the suggestions and concepts mentioned above, particularly 'circulatory territory'. New empirical data emphasise the difficulties these populations have in crossing certain frontiers or getting used to the feeling of de-territorialisation, a geographical concept of central importance in this study. The transnational social networks of these migrants are not borderless configurations: they cross clearly delineated territories, though they have no contact with the territory; they are not implicated in the social, political, cultural or economic life of the territory which they cross.

1 The notion of circulatory territory proposed by Alain Tarrius (1989) in Anthropologie du mouvement. The paradigm, refined in 2000 (Tarrius 2000) described a certain socialisation of those spaces which support displacement. Individuals acknowledge one another within the spaces which they enter or cross during a shared history of mobility, which triggers an original social bond.

2 Notion embraced by the Migrinter research team. 
However, this is not a permanent state. Since it is not permanent, migrants' de-territorialisation is therefore considered as relative, rather than absolute, in that it only lasts a period of time.

Such temporary de-territorialisation can therefore only be understood in relation to the re-establishment of links between migrants and the social relations present in the territory where they are resident: the re-territorialisation. Staged transnational migration is in fact a movement where the time and space of migration are punctuated by de-territorialisation, re-territorialisation and re-de-territorialisation as migrants are connected, disconnected and reconnected with the overlapping social spaces of their points of origin. In the case of sub-Saharan migrants, who often have no visas, the transnational migratory space they have established is not defined, and can extend over several years, straddling several countries which have not planned for their arrival or settlement. Hence, the space-time dimension must necessarily be reintroduced to this context, where migratory trajectories are punctuated into stages during which migrants reorganise themselves until the time arrives to cross the next border confronting them (Tarrius 1989).

Frontier effects do indeed persist, and it is the migrants' ability to overcome (or failure to overcome) those which confront them which helps most in understanding what these transnational dynamics mean. This involves a consideration of their circulatory know-how or 'savoir-circuler' (Tarrius 2001, 2007) - the way in which they organise themselves socially in time and space to achieve this - along with the way in which they take their own frontiers with them, transferring them to where they settle. For the sociologist, this most clearly manifests itself at the stopovers, where migrants settle by choice or necessity, for as long as it takes to get their bearings, reorganise themselves and sometimes to redefine their migratory project. ${ }^{3}$ It is these stopovers - whose organisation and regulation has been the focus of my own research for the past eight years - that enable them to organise their mobility and their stay. This chapter does not focus on the origin or destination societies, or on the so-called 'transit' societies, but rather on the connections forged by the migrants between these three that result in processes of de-territorialisation, re-territorialisation and re-de-territorialisation.

My research has considered this form of migration over the past eight years, using a qualitative, ethnographic approach involving the sub-Saharan African populations who shape it. I have tried to identify how the movement

3 As I have already shown, some decide to settle in the Maghreb countries for a longer period, without in any way abandoning their dream of reaching Europe (Alioua 2005). 
of these migrant populations expresses itself in social space and transnational territories, perpetuating the tensions caused by their mobility and their rootedness in the countries of the Maghreb and the Western Mediterranean in general and in Morocco in particular. This has involved more than 300 migrants - men, women, young people, refugees or 'adventurers' (as they describe themselves) - with whom I have established relationships, ranging from short- to long-term depending on the situation, and whom I have followed in their everyday lives. Where considered necessary, I have conducted biographical interviews, not restricting the analysis simply to local contexts and social organisations. In this way I have considered the opportunities offered by international migration. The researcher may become involved with these relational networks and, without becoming a member of the collective, have some contact with the everyday activities of the survey populations, exchanging small services. This technique is a variation of participant observation, what Alain Tarrius, Lamia Missaoui and I (amongst others) refer to as 'accompanying observation'. Unlike formal sociological surveys - statistics or monographs, which give the clearest picture of the morphology of populations and their organisation - it enables direct interaction and the establishment of relationships at the centre of the process we are concerned with. In fact, once confidence has been established, thanks in particular to certain meetings and relationships which may result from exchanging gifts, the researcher becomes part of the network.

In order to reconstruct the uncertain development of the transnational migratory experience I consider the links that sub-Saharan transmigrants create over the course of their journey and their impacts on the places in which they reside. The study raises the issue of the creation of unrestricted spatial configurations produced by these moving populations, within a geopolitical context where borders are not as porous as the term 'transnational' would suggest. The notion of the 'migration stage' or stopover becomes an observation location but also a methodological framework - providing a context for accompanying observation - and an analytical tool. The aim is to give an account of the social autonomy of these migrants and their capacity to get through borders and to renegotiate some of the basic assumptions about 'sedentary' peoples. Their border crossing 'savoir faire' contributes to the construction of transnational spaces in which they manage to circulate with varying degrees of success. The chapter also aims to identify the difficulties they have in getting through these 'trials' ${ }^{4}$ or 'barriers' which are

4 For a sociological view of the trial, particularly in the individuation process, see Martuccelli (2006). 
not only located at the geographical confines of nation states, but also within them, most often at the margins, such as in some of the peripheral districts of the larger towns and cities.

To circulate, there is a need for staging posts in which these populations can get their bearings and find all the information, connections and resources (economic, social and symbolic) needed, initially for survival and subsequently for the next part of the journey they wish to make. In the case of sub-Saharan Africans in Morocco who want to go to Europe but feel 'stuck', the main focus for sociological analysis should be the original migratory projects, at least those declared by the individuals. There could also be the temptation to reduce this type of migration to simple 'transit' and to talk of Morocco as a 'transit country', of this movement as a 'transit migration' and of these people as 'transit migrants'. But I would distance myself from these terminologies which I find not only unsatisfactory in terms of our sociological understanding, but also sufficiently ambiguous, politically, to mislead the researcher.

The term 'transit' has a particularly restrictive definition in space-time terms and is really not good enough for migration sociology. I understand 'transit' as the time one spends wandering about, for example in the terminal building at some international airport waiting for one's next flight. Furthermore, this term assumes subjective realities which vary depending on whether one is a migrant, a journalist, a politician, a lawyer, or even according to the country in which one finds oneself. This restrictive understanding of transit matches the place it occupies today within our societies, whether as a subject for discussion by 'experts' or as an issue in public debate (Morice n.d.). In Europe, for example, the term 'transit country' is curiously dedicated in its common meaning to the countries on the fringes of the EU, accentuating further the presumption of the exteriority of these countries and the idea that a 'natural' border separates the EU from the rest of the world. However, it should be remembered that countries such as Spain and Italy were considered transit countries in the 1990 s before becoming important immigration countries. Furthermore, countries formerly known as 'transit' countries, such as Cyprus or Malta, have changed status simply because of their entry into the union, becoming 'countries of first entry into the EU', whereas we are well aware that the majority of migrants do not wish to settle in these countries but to try and get into the Schengen area!

The notion of stopover conveys the complexity of migratory routes much better, replacing the space-time dimension, and does not become reduced during the waiting process into a 'non-place', like an airport, with a mini- 
mum of interaction before moving on to another. The stopover is a much longer and much more complex period during which social interactions and immersion are significant enough to transform, or at least to influence, those carrying out migratory activities, as much as those who see them passing by and settling. Stopovers bring actors together who did not previously know one another, who have developed their migratory project individually and independently within their own social environment, but who must now negotiate with each other and organise themselves collectively. They bring together actors who can be distinguished from one another by their origins and their aims.

Migratory trajectories are not smooth and often run into obstacles: in the case which concerns us here, they are governed by transnational networks that are affected by the border control policies introduced by nation states, and particularly the EU. Migrants must therefore reorganise themselves, working out strategies during their stay at the stopovers which stand a chance of overcoming the dissuasive policies. These strategies often reveal the density of their social networks. During their stopovers, sub-Saharan migrants, who are almost nomadic and always strangers in the societies they pass through, must of necessity acquire know-how and social skills during their process of de-territorialisation and re-territorialisation, of engagement in and disengagement from new social relationships. This encourages a certain distancing from so-called 'ethnic' belonging, which is all too often seen by researchers as irrevocable and insurmountable.

\subsection{The establishment of collectives in Maghrebian stopovers}

Since the generalisation of the visa regime across the Schengen area in the 1990s, the majority of Africans wishing to migrate to Europe now face restrictions on the issuance of visas. International migration in stages, dodging the state rules imposed to control entry to, residency in and exit from a national territory, has become one frequent scenario for African migrants, opening or reopening (Bredeloup \& Pliez 2005) new migratory routes from sub-Saharan Africa, through the Maghreb, to Europe. I refer to this as 'staged transnational migration' or 'transmigration'. While the need for immigrant labour remains high in Europe, depending on the sector, these increasingly restrictive migratory policies are paradoxical and have helped, to some extent, to encourage a number of Africans to embark on the route to what they call 'the adventure', and what the media and politicians call 'illegal immigration' or 'transit migration'. While this is not the only 
determining factor, ${ }^{5}$ a great many of these sub-Saharan migrants would have flown directly to Europe if they had been able to do so. However, the EU is neither a fortress nor a sieve. The numbers of people, male and female, who manage, either legally or illegally, to get across the frontiers and the numbers of those remain stuck en route, in countries where they had not planned to settle, give us an idea of the complexity of this form of migration, in which the dimensions of people's migratory projects must be taken into account.

In fact, while this migratory movement begins in many different ways, in terms of places, reasons and situations, once these actors have left home with their personal migratory project, they reorganise themselves collectively during the stopovers which punctuate their journey (Alioua 2003). To anchor themselves in these spaces, these migrants must collectively make up for an absence of territory by channelling their individual desire for mobility (Alioua 2005, 2010). So, having wandered the roads and crossed Africa from south to north, thousands of sub-Saharan transmigrants enter and relocate themselves collectively every year in the Maghreb, setting up stopovers which, since their establishment in the 199os, have continued to serve as migratory staging posts for newcomers. These staging posts have a social history which has gradually built up along the migratory trajectories. This is the fruit of the experiences built up by the first transmigrants, who organised themselves into collectives, which has been passed on and shared throughout the whole of the migratory networks. All of this has therefore required pre-existing social skills and the ability to learn new ones.

Since migrants are constantly moving from one place to another, they are confronted by things which are alien, new and unstable: this is clearly the opposite of the norm, of the 'habitus' (Bourdieu 1980) linked to a social order with a particular territory, a socially organised space to which this order applies. Feeling lost and alien to the societies in which they anchor themselves for a period of time, they gain their bearings as best they can, thanks in particular to their project which allows a certain social closeness with the other transmigrants, but also with the local people who share some of the same characteristics. Here it is not just the way in which these dynamics modify the material lives of these populations which concerns

5 South-South migrations are important as the classic South-North forms. It should also be remembered that the majority of African migrants reside in an African country, not in Europe. Furthermore, the stopovers which are being occupied today by Sub-Saharan migrants in order to complete their journey to Europe were often established by previous migratory movements in the Maghreb or West Africa (Alioua 2007). 
us, but also the way in which they tend to give an unprecedented role to the imagination. The imagination is not confined to certain specific domains, nor is it the preserve of certain social categories - like the myth of 'national identity' put about by the institutions and the elites for example (Anderson 1996) - but it plays a role in everyday practices, particularly in situations of poverty or marginality, like those resulting from transnational migration. These are situations where actors are obliged to reinvent themselves in their feeling of abandonment, in their wandering or their exile, a world of their own, using, for example, all the images that globalisation (Appadurai 2005) puts about and taking ownership of them.

To illustrate these dynamics in more practical terms, I echo words used by Mustapha Belbah to talk of young Moroccans who migrate 'clandestinely': all the sub-Saharan migrants surveyed see 'elsewhere as the universe of the possible' (Belbah 2002). We have shown that by over-valuing 'resourcefulness' and 'adventure' in this way, they reveal the dimension of individuality which lies within their staged transnational migration. In other words, by reclaiming the image of the entrepreneur in the sense of the 'self-made man', they turn the image of the 'victim' (not to mention the 'good savage') on its head, trying to show, if given the chance to express themselves, how far they themselves are the decision-makers in their lives. The interviews I conducted with dozens of these sub-Saharan migrants from all backgrounds over the past seven years led us to reach the same conclusion as Mustapha Belbah: the borders that these transmigrants want to 'burn' ${ }^{6}$ are firstly those which occupy a place in their thought world as a separation between the impossibility of personal achievement, of freeing oneself from family and social constraints, and transmigration which allows them to become the authors of their own future. As some young Malians said, 'We know what awaits us along the road. But we're already dead here! So physical death for a cause doesn't frighten us any more ... It's the only chance we have ... and we must take it!' By crossing the physical borders of nation states they hope also to cross those which, in their perception, separate the world of waiting and inactivity from the world of action and innovation.

In order to get through all these frontiers, particularly those symbolic frontiers which represent the move from childhood to autonomy as an

6 Moroccans, who make up the majority currently travelling these routes 'clandestinely' into Europe, use the term hrag - literally 'burn' - to express the action of crossing a border without official authorisation: they are very often called hragga, the 'burners'. But the important thing to remember here is that sub-Saharan migrants stopping over on the same journey as these Moroccan people now use the same words and have taken up this image for their own use. 
adult, ${ }^{7}$ migrants must develop mutual bonds of solidarity, despite the wish for individual emancipation. It is necessary to ensure the cooperation of the members of migratory networks, of those who want the same thing: to realise one's full potential, or, as they put it, 'to find your life. ${ }^{8}$ So it is on the basis of thinking and planning for the future, rather than identity, that collectives are formed to cope with adversity, organising themselves to work together because of the complementarity of their migratory projects. The notion of a project then becomes of interest because it highlights the link between social practices and appearances, and between imaginations and social action. One of the main characteristics of social action is that it contains a representation of the future which is sought, and it orders itself according to this representation. Projects give meaning to actions through this representation of desired aims.

Staged transnational migration is the result of a project, in the sense of the image of a situation which one hopes to attain - that is, everything by which people tend either collectively or individually to change the world which surrounds them, or to change themselves and their position within this environment. These migrants have an idea of elsewhere, like an idealised Europe, and want to get there: this is a project which finds meaning in migration itself, and is projected onto the spaces and borders which migration leads one to travel and to cross. The project is seen as an objective which ranks higher than all other goals. It seems then that they fulfil their potential as drivers of their own lives, equipping themselves with a migratory project which takes the place of a life plan or social mobility, and they gain recognition among themselves. They build an 'elsewhere' where everything becomes possible, an imaginary space of social fulfilment, and to get there they elaborate a plan in an imaginary elsewhere where they hope to find the means to achieve their ambitions. "The most important thing is to leave. You have to leave! You have to leave the country, then afterwards, everything is possible!' a young Ghanaian reported. Over the course of migration they collectively negotiate this journey, crossing together all the frontiers that they encounter (Alioua 2006), whether national, natural, social or cultural; their migratory project is realised first and foremost in the journey.

7 However, it should be remembered that the majority of these sub-Saharan migrants stopping over are young: of the 300 people we met, 257 were aged between 16 and 32 (Alioua 2010).

8 Sub-Saharan migrants stopping over often use the phrase 'I'm going to find my life' to explain and legitimise their migration. 
Following this, it is thanks to the network that this transnational migration is possible; it is the relational structure which allows the migratory project to be directed. The trajectories deriving from it, weaving de-territorialised relationships on the basis of a shared imagination and project. Migrants passing from one regulated area to another show those who follow how to succeed in this step on the basis of their own experiences. But this suggests that the signs marking out the routes are recognisable to all, in other words that a collective thought world brings all these individuals together, allowing actors to interpret the codes they have worked out. During the constant succession of such steps, migratory routes are also 'traced' in social terms; migrants leave little markers behind so that others can recognise and benefit from them. Distributing such information in this manner about the path to follow helps with the acquisition of one dimension of nomadic know-how: to set up a circulation by marking out routes or drawing up new ones to be able to travel them again or to help those following to travel them. This is why these 'venturers'9 are modern nomads. Let us look at how Adama, a young man from Cameroon, describes it.

MA: And when you got to Algiers, how did you manage to find houses ... How did you know where to go?

Adama: In fact there's ... when you arrive somewhere you look first for where you can find the ... black brothers. You're never alone. So with your friends you look for where the black brothers can be found. Everyone has information and you work together to find out how to see these brothers who will help us live here. There's a district where you find black brothers waiting by the side of the road for work. So there's a lot of them waiting. They hitch-hike to find a job. There's people turning up in cars to fetch them, to take them home, to do housework, or cleaning ... or to take you to a building site to do building work, or clean up the site, things like that ...

MA: And how did you know there was a district like that where the ...

Adama: Actually, when you're in Tamanrasset, you're already in contact with the people down there ... they've got phones and they tell us how it works down there. So once you're in Algiers you know where to go ... In

9 The 'adventure' is the way they like to describe their migration, defining themselves as 'venturers'. The fact that they describe themselves in this way reinforces the collective nature of such migration and also makes it possible to value it. 
fact it's the ones who go ahead of us, if someone goes ahead before me, we've got a phone box where we can call them, but most of the time we work by e-mail. We communicate with each other. An e-mail address is very important for us, it enables us to locate our brothers who have gone ahead ... then they try to tell us about the little difficulties on the way.

MA: And when you arrive, do you do the same thing for the people you've left behind?

Adama: Of course! For example, if I open my e-mails and a friend writes to me, I tell him for example, 'well, it's like this, it's hard, but if you want to make it, now you know the ropes, well this is what you have to do ...' That's how it is ... So, erm, 'that's it down there', 'we've found some jobs!' ... I've worked on building sites, really very, very hard work. I tried to save some money. Once I've saved up, I head off for Morocco ... that's how it is. Once I'm at Maghnia, the border between Morocco and Algeria, it's the same thing all over again. Maybe there are Algerians who provide papers, and that way you try to cross the border at night, or maybe there are brothers who act as guides ... well, there are brothers who left before us, and they're the ones who opened up the route! ... And all of that doesn't belong just to you! You also have to help the brothers following behind. Of course you can't do much ... you've already spent all your cash, for the guides and everything ... and that's for your own journey! But that's what you do. You communicate ... you exchange stuff and that's really important: you have to leave the route open!

So migrant populations from a variety of origins move through, circulate and settle in the stopovers from sub-Saharan Africa to the Maghreb, adding their own mobility, their own projects and their own migratory strategies. Hence the feeling that migratory paths have a tendency to mingle can produce an identity-forming process; coming from the same place, going through the same trials, circulating within the same areas with the same practices to get to the same places, in short having the same project and the same method of migration, this means belonging to the same historic movement, especially when one suffers the same setbacks (Clochard \& MIGREUROP 2009). These individuals gain recognition among themselves and cooperate because, little by little, they are creating a shared history, an 'adventure'. Their migratory project and methods of migration are similar and unite them (Alioua 2005). These migrants manage either individually or collectively to weave and activate social bonds without pre-established 
personal relationships of trust. During the stopovers where collectives are formed, trust is initially founded not on the intimate knowledge of the other, but on the fact of sharing the same project. This shows that trust is possible between people who do not know one another. These networked social forms connected through bonds which spread over time and space thus generate social bonds which take the place of communities where integration is by origin. This is particularly evident in the nature of the social bonds which are woven during the stopovers in which these migrants, on their 'circulatory territory', meet, cross paths, avoid one another, cooperate or come into conflict.

These stopovers are the locations where the bond is activated. Collective reorganisation, despite precarious situations, the diversity of origins and competition between migrants become indispensable strategies in this new form of migration. If these sub-Saharan migrants, whatever the status imposed on them and the origins they claim, see these stopovers as migratory staging posts, then it is because they think that here they will find social staging posts that will allow them to fit in and find the means for survival. More generally, if new sub-Saharan migrants are constantly arriving and circulating around the Maghreb, then it is because they find people at these stopovers who can show them how to fit in, in order to survive until their next departure. Relational density certainly implies a demographic density. Indeed, it is a matter of gaining a sufficiently embedded presence in the areas in which they find themselves that it will be possible for those following them to circulate there. Some of these migrants, particularly those who have a clear overview of their staged transnational migration, like the 'chairmen' for example, ${ }^{10}$ call this leaving the travelling route open'. This is to say that these stopovers have been migratory staging posts in which transmigrants can be sure of finding other transmigrants like themselves, able to help them, for example enabling the new arrivals to identify a district where they can find accommodation without difficulty and without the

10 The 'chairman' is a kind of manager for one or more collectives. He (for it is always a 'he') owes his position to his 'savoir-circuler', his experience of transmigration and particularly his knowledge of the social environment in which he finds himself, particularly his networks and relationships with 'important' people: smugglers, the police, lenders, potential employers, doctors, lawyers or activists defending the migrants' cause etc. He also generally surrounds himself with a 'policy committee' in which each person's role is defined, such as 'treasurer' for example. The chairman is a migrant-smuggler: he is part of the transmigrants' world, he has been introduced into the space he frequents, he has inherited experiences and relationship networks from those who were there before him, and in turn he 'resocialises' new arrivals. He has a capacity to work across several areas, far from the negative image of 'trafficker in human beings' that the media have constructed to describe him (Alioua 2003). 
risk of provoking rejection by the natives, to assimilate the way of moving from one place in the town to another and how to behave in these places by avoiding social control.

These services and information are sometimes subject to a financial transaction. Even when this is the case, it is only a way of surviving that is constantly subject to negotiation. This is an economic means which is fully 'embedded' (Granovetter 1985) in the social realm, to such an extent that there is not necessarily any actual financial payment. Furthermore, the transaction may take place later, during the course of financial services or help, for one person in particular or for the collective which takes care of the new arrival. This debt amassed by new arrivals enables exchange and solidarity, along the lines of 'give and take'. In collectives which are based on self-management, whose members claim to be free, in the sense that each individual has his own project but 'must be responsible regarding the other brothers', the new arrivals are assimilated through their active participation in the structure. The fact of becoming involved and participating actively in a collective enables the exchange and drives solidarity. Transmigrants' collectives which organise themselves in order to achieve their personal project can inform us about their degree of autonomy and the capacity of their actors to weave relationships with people they do not know, changing from weak link to strong link depending on the situation.

\subsection{The impact of transmigration on local populations}

But to live - or should we say to survive? - at these stopovers, migrants must also be accepted by the local population and cooperate with some of their neighbours, organising their diversity around common points and social values. That is to say that they must avoid social control by adapting their lifestyles; they must have the capacity to make what is distant closer. Migrants are typically able to continue to live there due to assistance from 'sponsors' ${ }^{11}$ who send them postal orders and who either live in Europe, at the other end of the network, or who are in the country of origin and make an investment in spatial dispersion by supporting a relative who is migrating. They also manage thanks to the solidarity of the collective in which they find themselves, and sometimes the solidarity of an NGO or Moroccan peoples. Due to state controls and repression, this transmigration can only be achieved by finding 'ways in' among the local populations. 
Transmigrants know how to slide into the gaps left undisturbed by the state and the margins which the native populations have found ways of negotiating locally.

MA: And when you got here, how did you find a house and everything?

Male Migrant: Well Morocco's a country ... it's a bit easier, there's no work, but the people are more open, more sociable ... so the brothers who are there, they help us to live ... they give us some money and we rent houses ... I rented a little house with some brothers ... for the moment it's ok, but the problem is there's no work here, so it's difficult to make a living, so every now and then I try to call my uncle who's in Europe, and he sends me a bit of money to get by on. Now, he doesn't send me stuff very often, but the other brothers also have brothers in Europe who also send them a lot of money, and they support me too, and that's how it is ... They support me from time to time, we live together, we're solid. Not like them at the embassy! They call us 'the risk-takers' ... they can't understand. And the Moroccan police hunt us down, they're really tough! But sometimes they help us or set us free because they know they're like us and that their brothers too want to migrate to Europe. Often the Moroccans warn us when the police are going to turn up ... That's how it is! Once, right, there was this old woman who was saying to me 'comrade, come here comrade!' I didn't understand why, and then the children started laughing all round me, they made fun of me. But the fact was that there was a GUS (Urban Security Group) at the bottom of the street, and she wanted to hide me in her house. Well, afterwards, she asked me to pay her for her help ... That's what Morocco's like! ... But I know a lot of brothers who have been helped by the Moroccans, who give them food ... Myself, I've also met nice, kind Moroccans ... who, who ... especially around Nador, well I had a family, where I came out of the forest [self-managed ad-hoc camps on the outskirts of the town], I went there to eat, they let me take showers, have a good bath, and they made up little parcels for me, little olives, oranges and bread, and then I'd go back to the forest for the night ... and the next day, if I still need food, I leave the forest and go into town and I try to see them, they give me advice and encouragement, then I go home ... well, they had a son too who had left without any papers and who had managed to get to Italy ... so people like them have really impressed me, you see ... they're people with a lot of love to show me ... so I don't know how I'd manage to meet them one day ... give back what's theirs ... but I simply say ‘God is great,' you never know. 
Little by little, some Moroccan towns have become, despite appearances, favoured stopovers for these sub-Saharan transmigrants, who find everything they need there to survive and to realise their migratory project. The stopovers where the sub-Saharan migrants live are working-class districts characterised by widespread mobility (Alioua 2007). So it is no coincidence that they shelter non-Moroccan migrants today having welcomed so many Moroccan nationals undertaking internal migration. These districts have always sheltered persons judged undesirable by the ruling classes of the time. During the years of 'apartheid' imposed by the French colonial system, country dwellers who wanted to settle in town were frequently rounded up in these districts and then expelled from the town. At the time of independence, the Moroccan authorities would sometimes end up reproducing the same violence: the socio-political history of these districts is strongly characterised by resistance against the authorities, by a fear of the state and a lack of trust in its agents.

In addition, a proportion of the inhabitants of these working-class districts has ended up emigrating to Europe (Hambouch 200o), and a huge population of young Moroccan men and women who live there wish to do the same. Today they harbour foreign 'illegals', as they did with the national 'illegals' who arrived during the rural exodus and piled into shanty towns in the hope of improving daily life. With a mixture of rejection and fascination, Moroccans living in very cramped conditions in these working-class districts where the transmigrants settle are impressed by the path these new arrivals have taken. Some young Moroccans learn from these transmigrants and open up a little more to the outside world. Sometimes plans are even worked out between Moroccans and Africans of two or three different nationalities, working together to find the best way of getting into Europe. They exchange advice and information on what they have been able to learn themselves from someone they know who has already attempted the journey, or who simply lives in Europe and gives them advice on the best way of moving around without getting caught. Each has their own basic idea about the issue, but by pooling these ideas they increase their chances of success.

There are also mixed couples which form, between Moroccans and sub-Saharan Africans, and their plan is often to get into Europe together. Leaving aside the more or less hidden or assumed affectionate relationships (short-lived affairs) between Moroccan women and sub-Saharan African men, there are 'regular' mixed couples which form in this district of Morocco. They are certainly few in number, but not marginally so. In these places they are common knowledge and they can be found in all working-class districts. In the city of Rabat alone I met 27 mixed couples, 
five of whom had one or more children. The majority of these couples marry, even if the men are not in a regular situation as far as the authorities are concerned. This is possible because, rather like under rural practices, it is sufficient for a certain number of witnesses (men) to endorse the marriage for it to be legitimate, at least in the eyes of family and neighbours. Thus they do not need to apply to the Cadi or Adoul. The husbands are just as frequently Christians as they are Muslims. But in order to marry, Christians have to convert to Islam; most of the time, all they have to do is to recite the Fatiha in public and choose a Muslim first name. The feast which follows, by virtue of its public nature and the publicity it generates, legitimises the marriage. However, I have only met one mixed couple comprising a Moroccan man and an Ivorian woman (Christian). Although at least one third of sub-Saharan transmigrants are women, one does not find the same proportion among mixed couples. It must be said that Moroccans often consider these women to be prostitutes whom they can use as best suits them. In the minds of many men, be they Moroccans or migrants, these routes are not the place for single women; and therefore, in their minds, they imagine those who are there without the (supposed) protection of a man to be amoral.

All these social relationships are evidence of the emergence of new forms of cosmopolitanism, which extend beyond the national frameworks and institutions for socialisation and identity creation within Maghrebian society: complementarity merges into both a kind of rejection of the nation state ${ }^{12}$ and the formulation of a project to move to another place where everything becomes possible. These values are also those of youth, which tries to be the author of its own destiny.

The sub-Saharan migrants and their Moroccan neighbours also meet in queues at the Western Union, where they come to pick up their money order sent by a relative living in Europe. In fact, like the sub-Saharan migrants, many of the people who live in these districts survive thanks to money orders sent by a relative who has emigrated abroad, and many small houses have been built thanks to these transfers. In the urban setting, the number of owners and co-owners overtook the number of those renting at the end of the 1980 . The influence of unofficial building companies has encouraged this trend, and it is in these districts that self-finance represents 80 per

12 For these social groups, the nation state is that which imposes, assigns, controls and prevents the crossing of borders, which represses but offers no solution. 
cent of homes produced, ${ }^{13}$ at its height. Generally, these new owners build one floor at a time, and they repay the loan by renting out rooms. They then rent out a room, or the ground floor perhaps, whilst they themselves live at the top of the building. Most of those renting are migrants from the interior: workers who have come to work in the city, who have left their family behind and send back the majority of their wages. Sub-Saharan migrants on a stopover also make up a proportion of the people who rent, the number of whom has been underestimated, but which enables some of the Moroccans in these districts to achieve ownership, or to share the rent in the case of sub-letting. This suggests the degree of interdependence, as can be seen with the naked eye: the floors of these small houses in the working-class districts are getting more and more crowded.

Sub-Saharan migrants play a role in the local economy, which is mostly an informal economy, and are transforming the urban scene. Thus they have fully integrated themselves into the urban fabric of these towns, particularly the areas on the margins of the so-called legitimate town, transforming them by their presence. Moroccans have made room for them in spite of themselves. Admittedly, it is often a secondary position, tainted with contempt and domination, but at other times real cooperation develops, or at least relationships based on interdependence.

Over time the difficulty of getting into Europe and the repression exercised by the Moroccan authorities have encouraged sub-Saharan migrants to change their strategy. Up until 2005, migrant collectives paid very little attention to advocacy. After 2005 and the tragic events of Sebta and Melilla (MIGREUROP 2006), the collectives of sub-Saharan migrants, who were rather discreet (for example, they would often refuse to be interviewed by the media, and when they did accept would only in exceptional cases speak out about the demands made of them), took on a special dimension, changing from the simple function of mutual assistance to political militancy (Alioua 2009). In Morocco, at least nine political associations (not all of which are officially recognised) have thus been set up and their members, in increasing numbers, not only fight for respect for their rights in Morocco, even if they do not wish to settle there permanently, but are also engaged in advocacy at an international level for the right of asylum and claim their right to be allowed to circulate freely.

In Morocco, with the help and assistance of a considerable part of the civil society, human rights activists and foreigners working with interna-

13 Source: CERED (Centre for Demographic Study and Research) and HCP (High Commission for Planning), 2005, Rabat, Morocco. 
tional NGOs, these new transnational actors have appeared not only on the Moroccan public scene, but internationally too. ${ }^{14}$ The loss of some of their fundamental rights - through the simple fact that they have crossed a border without permission or have extended their stay unofficially - has therefore not translated directly into disappearance from the public arena or increased invisibility. This ability to make their voice heard is the sign of their capacity to negotiate, albeit a relative and fragile one. This also tells us something about the degree of democratisation of the region. It is a significant characteristic of democracy that it allows the existence of a space which is opened up for marginalised populations to fight for their rights; even when their de facto exclusion cannot entirely be overcome and there is irresolvable inequality, the relative equality encouraged by political struggle can at least allow it to be limited (Péralva 2007).

Thus, while the moving frontiers of the EU slide into the interior of the Maghreb, alienating a number of migrants from the right to have rights, ${ }^{15}$ the same movement opens up the possibility of resistance to the militants who profit from this fluctuation on the borders, using the democratic arguments of this same Europe, then paradoxically including new rights which are still in an embryonic state. For, as international law has evolved, for the first time nation states are subject to supranational authorities (Sassen 2005), which leaves the field open to organisations which attempt to use the law to impose their own demands, even when they run contrary to national interests.

The example of 'transnational resistance' (Urry 200o) in the face of the so-called European policy of 'externalisation' (Rodier 2006) of the control of migratory flows in the neighbouring countries, in which sub-Saharan transmigrants play an important role (Alioua 2009), is a remarkable example of the transition from the image of a world divided by state borders, which is gradually being supplanted by a multidimensional image revealing a density of relationships. But to be able to observe these fluid, liquid (Bauman 2000) phenomena in practical terms, we need interstices in which they materialise, solidify, in an instant in time. We therefore feel that the notion of a stopover is precious to our understanding, not only of current

14 They organise sit-ins, have occupied a church in Rabat, are well-represented on circulation lists and Internet discussion forums, take part in conferences etc. For more information, see Alioua (2009).

15 As for the situation facing transmigrants and asylum-seekers waiting for their status to be granted, more and more researchers have adopted Hannah Arendt's well-known formulation. In the case of Black Africans in the Maghreb, see the report from one Moroccan NGO (GADEM 2007). 


\section{transnational migrations but also of the socio-political dynamics linked to globalisation (Sassen 2007).}

\section{References}

Alioua, M. (2003), Réseaux, étapes, passages, les négociations des subsahariens en situation de migration transnationale: L'exemple de leur étape marocaine à Rabat, TERRA-Edition, Coll. 'Masters', http://terra.rezo.net/article275.html.

Alioua, M. (2005), 'La migration transnationale des Africains subsahariens au Maghreb: L'exemple de l'étape marocaine', Marges et Mondialisation: Les Migrations Transsahariennes 185, Maghreb-Machrek.

Alioua, M. (2006), 'Silence! People are dying on the southern borders of Europe: Sub-Saharan transmigrants face the externalization of migration management to North', in U. Biemann \& B. Holmes (eds), The Maghreb Connection: Movements of Life Across North Africa. Barcelona: ACTAR.

Alioua, M. (2007), 'Nouveaux et anciens espaces de circulation internationale au Maroc: Les grandes villes Marocaines, relais migratoires émergents de la migration transnationale des Africains subsahariens au Maghreb', Migrations Sud-Sud 119-120: 39-58.

Alioua, M. (2009), 'Le passage au politique des transmigrants subsahariens au Maroc', in A. Benssaâd (ed.), Le Maghreb à l'Epreuve des Migrations Subsahariennes. Paris: Karthala, 279-303.

Alioua M. (2010), 'Jeunes transmigrants subsahariens au Maroc', in F. Lorcerie (ed.), Pratiquer les Frontières:Jeunes Migrants et Descendants de Migrants dans l'Espace Franco-Maghrébin. Paris: CNRS-édition.

Anderson, B. (1996), L'Imaginaire National: Réflexions sur l'Origine et l'Essor du Nationalisme. Paris: La Découverte.

Appadurai, A. (2005), Après le Colonialisme: Les Conséquences Culturelles de la Globalization. Paris: Payot.

Bauman, Z. (200o), Liquid Modernity. Cambridge: Polity Press.

Belbah, M. (2002), 'Confluences Méditerranée', L'immigration bouscule l'Europe 42: 37-40.

Bourdieu, P. (1980), Le Sens pratique. Paris: Minuit.

Bredeloup, S., \& O. Pliez. (eds) (2005), 'Migrations entre les deux rives du Sahara', Autrepart 4 (36).

Clochard, O. \& MIGREUROP (eds) (2009), Atlas des Migrants en Europe: Géographie Critique des Politiques Migratoires. Paris: Armand Colin.

GADEM (2007), 'La chasse aux migrants aux frontières Sud de l'UE: Conséquence des politiques migratoires européennes. L'exemple des refoulements de décembre 2006 au Maroc'. Rabat: GADEM.www.migreurop.org/IMG/pdf/RAPPORT_GADEM_20_o6_20o7.pdf.

Glick-Schiller, N., L. Bash \& C. Szanton Blanc (1995), 'From immigrant to transmigrant: Theorizing transnational migration', Anthropological Quarterly 68: 48-63.

Goldschmidt, E. (2002), 'Migrants congolais en route vers l'Europe', Temps modernes 620-621: 208-239.

Granovetter, M. (1985), 'Economic action and social structure: The problem of embeddedness', American Journal of Sociology 91: 481-510.

Hambouch, B. (ed.) (2000), Les Marocains Résident à l'Etranger: Une Enquête Socioéconomique. Rabat: INSEA.

Hily, M.A., F. Loyer \& E. Ma Mung (eds) (1998), Bilan des Travaux sur la Circulation Migratoire, Ministère de la solidarité et de l'emploi. Poitiers: Migrinter. 
Martuccelli, D. (2006), Forgé par l'Epreuve: L'Individu dans la France Contemporaine. Paris: Armand Colin.

MIGREUROP (2006), Guerre aux migrants: Le livre noir de Ceuta et Melilla. www.migreurop. org/IMG/pdf/livrenoir-ceuta.pdf.

Morice, A. (no date), 'Conceptualisation des migrations et marchandages internationaux', in A. Bensaâd (ed.), Immigration sur Emigration: Le Maghreb à l'Epreuve des Migrations Subsahariennes. Paris: Karthala, 195-214.

Péralva, A. (2007), 'Démocratie à la marge', in M. Wieviorka (ed.), Les Sciences Sociales en Mutations. Auxerre Cedex: Editions Sciences Humaines, 571-579.

Rodier, C. (2006), Analyse de la Dimension Externe des Politiques d'Asile et d'Immigration de l'Ue: Synthèse et Recommandations pour le Parlement Européen. Bruxelles: Direction Générale pour les Politiques Externes de l'Union.

Tarrius, A. (1989), Anthropologie du Movement. Orléans: Paradigme.

Tarrius, A. (2000), Les Nouveaux Cosmopolitismes. La Tour d'Aigues: L'Aube.

Tarrius, A. (2001), 'Au-delà des Etats-nations: Des sociétés de migrants', REMI 17 (2): 37-62.

Tarrius, A. (2002), La Mondialisation parle Bas: Les Nouveaux Nomades de l'Economie Souterraine, Voix et Regards. Paris: Balland.

Tarrius, A. (2007), La Remontée des Sud:Afghans et Marocains en Europe Méridionale. La Tour d'Aigues: L'Aube.

Urry J. (2000), Sociology Beyond Societies: Mobilities for the Twenty-First Century, International Library of Sociology Series. London: Routledge.

Sassen S. (2005), Denationalization: Territory, Authority and Rights in a Global Digital Age. Princeton: Princeton University Press.

Sassen S. (2007), A Sociology of Globalization. New York: W.W. Norton \& Company. 


\title{
$5 \quad$ Trying to Transit
}

\author{
Irregular Immigration in Malta
}

Cetta Mainwaring

\subsection{Introduction}

The Mediterranean Sea has always been a passage for human movement, carrying flows of people and goods on its currents, be it tourists on yachts and cruise liners, soldiers on naval vessels, sailors on container ships, or migrants on dinghies. More recently, at the turn of the twenty-first century, the central Mediterranean experienced an increase in irregular transit migration, as migrants and refugees search for new routes into Europe and attempt the dangerous voyage from the poorer southern shores to the richer northern ones.

At the heart of the Mediterranean, Malta simultaneously bridges and divides North and South. Its geographic, political, and economic position places it at a crossroad, where tension is palpable: it lies just inside an arbitrary border, a fact that designates it as part of the wealthy club that is the European Union (EU), while mere miles across the sea lie the disqualified countries of Africa. As one of the 2004 accession countries, Malta's borders have been redefined as external borders on the southern periphery of the ever-evolving Union. Influenced by its EU membership, the island is now faced with new challenges in terms of the nature of migration to the island and the subsequent policy responses.

Although part of the EU, Malta is a minor political player with little power to influence policies. Thus it continues to bear what the government views as a disproportionate amount of the migration 'burden' facing the EU, especially in light of stipulations under the Dublin II Regulation. ${ }^{1}$ Moreover, despite Malta seeing itself and often being viewed by migrants as a transit point en route to mainland Europe, it has now become more of an outpost. Policies simultaneously attempt to deter arrivals, as well as restricting migrants' ability to transit to other countries. The multiple national and supranational interests at play result in contradictory logics within the restrictive policies. This has implications both for the Maltese population that faces new realities of immigration to the island and for the migrants 
and refugees, who must often resort to irregular and sometimes dangerous methods in an attempt to leave the island.

An island state, located a stone's throw from the North African coast, Malta's geographic and political parameters influence both the type of immigration experienced and the policies enacted to manage these migration flows. Within the context of the emphasis in the EU on externalising asylum and migration policies, this chapter examines the new role that Malta is undertaking as an external border state and how this role affects the patterns of transit migration and the migrant experience in the Mediterranean. The chapter looks, firstly, at the development of EU migration policy and how it has shaped Maltese policies, before turning to the experiences of and strategies employed by migrants and refugees on the island. In concluding, it turns to the concept of transit migration and assesses its relevance in describing irregular immigration patterns in Malta.

\section{2 $\quad$ EU migration policy}

Over the past twenty years, as the EU relaxed its internal borders, member states have introduced restrictive measures aimed at fortifying the external borders and targeting non-EU nationals. Designed to deter unauthorised migrants, including asylum seekers and refugees, from turning up on their doorstep, these include: extended visa requirements, carrier sanctions, increased patrols of land and coastal borders, expedited asylum applications, the principles of safe country of origin and safe third country for asylum seekers, expulsion of undocumented migrants, restrictions on freedom of movement, limitations on the right to work, and the exchange of information with other Schengen countries about immigrants perceived as undesirable (Baldwin-Edwards 2004; Crisp 2003: 8). Although these policies are fundamentally pertinent to the national context in encompassing questions of citizenship and security, the EU has created new opportunities for control and more restrictive measures by, for example, increasing security cooperation above that possible at the domestic level.

There is also an evident desire to externalise immigration controls toward and beyond the EU's external borders, an aspiration established in 2003 in the UK's unsuccessful proposal to create Regional Protection Zones and Transit Processing Centres that would restrict the number of people entering and applying for asylum within the EU. It was envisaged that these Zones would be established on the outskirts of the EU, and most asylum applications would be considered there rather than within EU borders (Noll 
2003; House of Lords 2004). The proposal raised many concerns, such as the lack of incentives and resources for countries outside the EU to guarantee minimum human rights standards. Although the proposal failed, the concepts and ideas behind it have nevertheless gained prominence over more progressive proposals, such as development assistance, debt reduction, and the promotion of human rights and good governance in migrants' countries of origin (Schuster 2005; Andrijasevic 2006).

Indeed, the same logic is evident in bilateral agreements that address the readmission of irregular migrants and the co-operation of law enforcement between EU member and non-member states. Due to the slow process of harmonisation of asylum policies at the supranational level, there has been a proliferation of such agreements made with non-member countries that border the EU, often in order to negotiate readmission agreements. For example, since 2003, Morocco, in exchange for development aid, has collaborated with Spain on joint patrols and the readmission of migrants, including non-nationals who may have transited Morocco (Cuttitta 2007; Lutterbeck 2006; Geddes 2005). More recently, Italy and Libya have signed a Treaty on Friendship, Partnership and Cooperation (2008), which calls for joint operations between the two countries to patrol Libya's maritime border. In return for Libya's cooperation in curtailing irregular immigration, Italy pledged five billion dollars in colonial reparations over the next 25 years.

Understandably, human rights organisations have responded with fierce criticism to these diplomatic developments with countries that have, at best, dubious human rights records (e.g., Human Rights Watch 2006). For example, the Libyan judicial system has no asylum procedure in place and is not a signatory to the $195^{1}$ Geneva Convention that provides the legal framework for refugee protection. In light of these factors, the agreements are seen as attempts to deny access to the asylum system within Europe and to externalise immigration controls.

Such bilateral agreements, as well as the portrayal of migration as a security challenge (European Council 2008), have also fostered a militarisation of the southern European border, where governments increasingly deploy military and semi-military forces and hardware in attempts to prevent migration by sea. This security framework has become even more prevalent in the aftermath of the 11 September 2001 terrorist attacks and the subsequent attacks in Madrid and London (Lutterbeck 2006; Andrijasevic 2006).

\section{Mediterranean crossroads}

The Mediterranean Sea finds itselfliterally in the middle of the debates over migration and has been characterised as the 'soft, vulnerable underbelly of 
Fortress Europe.' ${ }^{2}$ As dead bodies wash up on its beaches and many more drown without leaving a trace, 'boat people' continue to make the perilous voyage across the sea in hopes of reaching the privileged shores of Greece, Italy, and Spain. The Mediterranean has thus truly become a crossroads, an area of transit migration. The new members of the EU, whose borders are more porous due to long coastlines and large expanses of territorial waters and search and rescue areas, are now in a new and difficult position of acting as Europe's gatekeepers. In this context, the changes in EU policy discussed above have impelled these countries to adopt increasingly restrictive migration policies (Baldwin-Edwards 2004).

Moreover, the transformation from countries of emigration to those of immigration has produced social, economic, and legal issues, for which administrations have not been prepared. Unfortunately, host populations have seen an increase in hostility towards non-EU nationals, who are perceived as a threat to the national culture and economy (Triandafyllidou 2001: 90). The restrictive response in policy, coupled with the media exploitation of the issue, has led to the marginalisation of migrants as 'desperate', 'illegal', and 'unwanted', and an associated eruption of racism and xenophobia in many countries (Katrougalos \& Lazaridis 2003: 180-181). As Martin Baldwin-Edwards (2004) notes, one of the biggest failures has been the inability of governments in Southern Europe to accept the changing patterns of global migration and to move beyond treating immigration as an emergency situation.

Accordingly, much attention is given to easily sensationalised phenomena, such as migrants risking and losing their lives in attempts to cross the Mediterranean on unseaworthy vessels. These events are certainly a human tragedy, but are also exploited by states to justify restrictive migration policies, as was evident in the asylum panic of the 1990 and the more recent focus on the 'hordes' of people waiting at Sangatte or in Libya wishing to migrate into the EU. Many headlines added to the scaremongering by reporting that in Libya, for instance, ' $[\mathrm{u}] \mathrm{p}$ to a million await calmer spring seas before risking their lives to cross the Mediterranean' (Townsend 2008). Academics and NGOs dispute these figures based on evidence that suggests that very few of the migrants in Libya attempt to cross the Mediterranean. ${ }^{3}$

2 This label originated in World War II, and was used by Winston Churchill during the invasion of Sicily to note where the Axis forces were most vulnerable. It has now been adopted within the EU's discourse on migration (Katrougalos \& Lazaridis 2003: 169; Haynes 1999: 19).

3 This is of course difficult to establish as migrants' plans may change as new opportunities or limitations arise. Nevertheless, research has shown that most migrants in these countries do not continue on to Europe (De Haas 2007; Cuttitta 2007). 
One indication of this is the small numbers apprehended on islands such as Lampedusa or Malta, and on the Mediterranean borders of countries such as Italy and Spain. ${ }^{4}$ Apart from the evidence of apprehensions and deaths, the number making the journey across the Mediterranean is difficult to ascertain as it includes migrants who succeed in making the journey without detection, those who lose their lives at sea and whose bodies have not been recovered, and others who are thwarted in their attempts to leave North Africa before ever reaching EU waters. Despite the difficulties involved in gathering such data, the United Nations High Commissioner for Refugees (UNHCR 2009a) estimates that 67,000 people crossed the Mediterranean Sea to reach Europe in 2008.

In the middle of the Mediterranean, Malta finds itself on the geographic and political fringes of the EU. Although the small island has increased its political power by joining the EU, it is still a minor player and has been expected to increase migration controls and fortify its borders in order to fulfil the role of a gatekeeper. As a border state and an island, it is acutely aware of the consequences of this logic. The Dublin II Regulation, which all member states must adhere to as part of the Community acquis, stipulates that asylum seekers must apply for asylum in the first EU country they reach, ostensibly to reduce the risk of 'asylum shopping.' The Maltese government views the Regulation as the reason for a disproportionate number of migrant arrivals on the island, due to articles concerning Search and Rescue (SAR) missions.

Malta's SAR region spans over 250,00o square kilometres of the Mediterranean (roughly equivalent to the size of the United Kingdom) and effectively means that every boat leaving Libya passes though the region. ${ }^{5}$ Before joining the EU, Malta's informal policy was to help boats in distress before sending them on their way to mainland Europe, generally their intended destination. However, due to the Dublin II Regulation, the government is currently required to process the asylum claims of migrants who the Armed Forces intercept within the SAR region. Although the Armed Forces are expected to come to the aid of boats in distress in the region, they allow others to pass through without intervening. The boats asking for assistance

4 In 2005, Maltese authorities apprehended 1,822 irregular migrants at sea (National Statistics Office 2006). In Greece, the number was around 5,000 during 2005 (Triandafyllidou 2008). The same year, Spanish authorities apprehended 11,781 irregular immigrants at their southern sea border (including the Canaries, Andalusia, and the Balearic Islands), while Italian authorities apprehended 22,824 on their southern sea borders (including Sicily and other minor Sicilian islands) (Cuttitta 2007: 2-3).

5 For an exact map see www.sarmalta.gov.mt/sar_in_Malta.htm. 
are brought into Maltese ports and the migrants aboard are transported to one of the detention centres on the island (interviews, Senior Officials, Ministry for Justice and Home Affairs [MJHA]; Maltese Member of the European Parliament [MEP]; Refugee Commissioner, July 2006).

This change in policy, along with an increase in the number of arrivals, has prompted the government to maintain that it carries a disproportionate amount of the migration 'burden' in Europe, an argument made vociferously at EU fora. The answers, it claims, lie in 'solidarity amongst member states' (interviews, government officials, 2008-2009), by which it signals relocation schemes that would see those asylum seekers given protection in Malta resettled to other EU member states, ${ }^{6}$ and in renegotiating the Dublin II Regulation in order to add a proviso that would exempt countries facing particular pressures. After some years, Malta succeeded in garnering a limited amount of support for its demands for more 'solidarity' and 'burden-sharing' in the EU: member states have agreed to resettle a small number of refugees from Malta (European Parliament 2010: 16, 46) and the issue of countries facing particular pressures appears in the European Pact on Immigration and Asylum (2008). However, these agreements remain voluntary and ad hoc, with little political will apparent amongst other member states to implement a permanent intra-EU resettlement scheme.

The relationship between the EU and Malta is thus a complex one. On the one hand, the EU has had obvious effects on Maltese migration policy. By joining the Union, Malta automatically became party to the Dublin II Regulation, legislation it had no part in drafting, and has had to align its policies with EU directives. More indirectly, as a border country, it has come under pressure to act as a gatekeeper to the EU by introducing restrictive migration policies both in terms of deterring arrivals as well as restricting onward movement to continental Europe. However, it would be wrong to suggest a purely hierarchal relationship between the EU and Malta. The Maltese government has also used EU directives to publicly justify controversial policies, as well as exploited its image of a small, vulnerable state in crisis in order to garner more supranational support. For example, the government justifies its immigration detention policy in part as a means to hinder onward migrant mobility from Malta in line

6 The relocation of asylum seekers, whose claims have not yet been decided and who may not ultimately qualify for protection, is a longer-term goal for the Maltese government. This, however, is even less popular with other member states (interviews, government officials 2008-2009, Quadro Group 2009). 
with the conditions of the Dublin II Regulation (interview, Jesuit Refugee Services [JRS], June 2006).

Nevertheless, government officials also point to contradictory messages coming from EU member states. Countries criticise Malta for its detention policy, while simultaneously advising the government to be cautious regarding security and migration, not to allow migrants much freedom, and to share intelligence about them with other countries' security services (interviews, Permanent Secretary, MJHA, July 2006; Maltese MEP, March 2009). The tension appears to lie between national and supranational priorities and interests, resulting in simultaneous attempts to deter migrants and refugees from arriving in Malta (a national priority) and to hinder their onward mobility (a European Union directive).

What is clear is that the Dublin II Regulation and EU membership have redefined Malta's borders, and thus required their fortification through the incorporation of more restrictive migration controls facilitated by new technologies and expertise. These implications are conditioned by the fact that Malta is a state with blue borders. This has had two crucial consequences: first and perhaps foremost, the reality of blue borders results in a high degree of immobility for migrants and refugees on the island, especially in light of the Regulation's authorisation of surveillance measures used to return asylum seekers to the first country of arrival within the EU. Secondly, these blue borders are much more difficult to control than land borders as they cannot be demarcated in the same fashion, by building a wall or establishing guard towers. Sea borders are also multiple, involving layers of different types of inclusion and exclusion. Territorial waters, contiguous zones, exclusive economic zones and search and rescue regions encompass progressively more of the Mediterranean, causing the Maltese SAR region $\left(250,000 \mathrm{~km}^{2}\right)$ to be much larger than the island's territorial waters $(3,800$ $\left.\mathrm{km}^{2}\right)$. Furthermore, even when boats are intercepted within these waters, it is impossible to return migrants without the cooperation of bordering countries, such as Libya.

Dividing the Mediterranean: Malta, Italy, and Libya

The evolution of Maltese migration policies in light of EU accession has had repercussions on Malta's relationship with Libya. Historically, Malta and Libya have enjoyed good relations, which were formalised in the 1984 Treaty of Friendship and Co-operation. Among other things, the Treaty allowed Maltese and Libyans to travel between the two countries without a visa, a practice that was upheld until 2004, when Malta joined the EU. The influx of migrants from Libya into Malta after 2001 further strained relations 
between the two countries; although Maltese officials maintain that they continue play an important role as a mediator between the EU and Libya. ${ }^{7}$

Nevertheless, the irregular migration flows from Libya to Malta between 2002 and 2009 produced frustration among Maltese authorities and the wider public who believed that Muammar al-Gaddafi was not doing enough to stop migrants from leaving Libya's ports and attempting to make the voyage across the Mediterranean to Europe - Malta's own informal policy before joining the EU (interviews, Maltese MEPs, July 2006).

Without Libyan cooperation, interstate disputes between Italy, Libya and Malta frequently occurred over responsibility for irregular migrants at sea, often leaving the migrants stranded during the negotiations. Most notably, in 2007, 27 irregular immigrants clung to a Maltese tuna pen in Libyan waters for over 24 hours after the owner refused to accept them onboard. After much political wrangling between Libya, Malta and Italy, the migrants were eventually transferred to an Italian navy vessel that took them to Italy (Bilefsky 2007). Malta's large SAR region exacerbated the conflict over responsibility as it includes the island of Lampedusa and thus boats in need of rescue are sometimes inside Malta's SAR region, but closer in proximity to Lampedusa. ${ }^{8}$ The initiation of FRONTEX ${ }^{9}$ operations in the central Mediterranean in 2007 was in part an attempt to remedy this growing political tension, although the Maltese government was forthcoming in discussing complementary goals that might be attained through the joint patrols. The Permanent Secretary at the Ministry for Justice and Home Affairs (interview, July 2006) said, 'The scope is more as a deterrent'.

Other politicians and NGOs questioned the effectiveness and legitimacy of the patrols. One Maltese member of the European Parliament (interview, July 2006) underlined the fact that these types of measures 'turn people away indiscriminately, whatever their story ... creating a barrier to people, not hearing their story, just turning them back to whatever their fate is back at home.' Moreover, without Libya's cooperation, FRONTEX was un-

7 For example, they organised a meeting in July 2005 on the issue of saving the lives of migrants in the Sahara Desert and in the Mediterranean Sea, which was only attended by Libya because it took place in Malta (interviews, Permanent Secretary, MJHA, July 2006; Maltese Ambassador to Libya, July 2008).

8 In cases like this, Malta claims that the irregular migrants are Italy's responsibility because they must be taken into the nearest safe port, while Italy claims they are Malta's responsibility due to being within Malta's SAR regions. See for instance the statement released by the Maltese prime minister after the Pinar incident in 2009 ('Ministerial Statement regarding the immigrants who were rescued by the M/V Pinar-E off Lampedusa', 21 April 2009).

9 FRONTEX is the EU's external border security agency. 
able to return migrants and thus acted as a rescue team, helping boats in distress and taking those on board to the nearest safe port, often Malta or Lampedusa, rather than stemming the flow of migrants trying to enter Europe, its professed aim. ${ }^{10}$ FRONTEX's executive director admitted that the agency's 'increased level of operational activities ... might be serving as a pull factor for traffickers' (Camilleri 2008).

Respite from this interstate conflict came in the form of the ItalianLibyan Treaty on Friendship in 2008 that paved the way for Italy to return irregular immigrants found at sea to Libya. Malta embraced this new development without reservation, not least because it has tried unsuccessfully to negotiate a similar agreement with Libya in the past and hopes that this precedent will allow it to reopen these negotiations with new political weight (interviews, senior officials, MJHA and Ministry of Foreign Affairs [MFA], July 2006, April 2009). The government also correctly assumed that the agreement would limit irregular migration to the island; in 2010, arrivals had dropped to 47 (ECRE 2011).

Many NGOs have responded critically to this development, voicing their concern over protecting the right to asylum in Europe (Human Rights Watch 2009a, 2009b; UNHCR 2009a). Indeed, such an agreement is questionable when considering that most of the migrants coming from Libya are not Libyan, but are from sub-Saharan Africa. It could therefore effectively result in refugees being returned to their country of origin, contravening the principle of non-refoulement. Moreover, Libya is not party to the $195^{1}$ Geneva Convention that upholds the rights of refugees and asylum seekers; thus their commitment to human rights cannot be assumed (interviews, MP, UNHCR Malta Representative, July 2006). NGOs in Malta have echoed these sentiments, accusing the government of trying to find an easy and convenient solution to the problem of repatriating irregular immigrants by sending them to Libya, while ignoring the human rights issues involved (interview, JRS, June 2006).

Passing the buck and shirking responsibility for immigration is a continuing trend among most countries, not just Malta. A few years before Malta joined the EU, Italy unsuccessfully proposed that the EU set up large detention centres in Malta and Cyprus, where all irregular migrants and refugees of the Mediterranean region would be kept. Italy has also attempted to hold Malta responsible for stopping every boat of migrants coming through its

10 Italy initially also refused to cooperate, claiming the Nautilus II was futile without Libyan support. One can see from the FRONTEX reports (2009) that Spain, on the other hand, has been able to turn back migrants due to their agreement with Senegal and Mauritania. 
SAR region, not just those in distress. This would effectively mean that no boats would arrive in Lampedusa or in Sicily, as nearly all pass through the Maltese SAR region (interview, Permanent Secretary, MJHA, July 2006). For obvious reasons, Malta has refused to enter into such agreements, but nevertheless continues to try to procure similar agreements with Libya.

\subsection{Malta}

Malta is the smallest (both in terms of area and population) and most densely populated country in the EU, as well as its southernmost member. The country comprises of 316 square kilometres and the population of the island is 405,165 . The result is a population density of 1,282 persons per square kilometre, the highest in Europe and the third highest in the world. The island is also situated go kilometres south of Sicily, 29o kilometres from the northern coast of Tunisia and 360 kilometres from Libya.

The history of refugee law in Malta reflects the history of a country of emigration rather than immigration. Until the 2001 Refugees Act, ${ }^{11}$ no such legislation existed in Malta and the UNHCR office in Rome processed the limited number of asylum claims made on the island. The office was also responsible for providing financial assistance to recognised refugees, as well as overseeing resettlement schemes. In passing the Refugees Act of 2001, in order to align itself with other EU member states, Malta created its own structures to manage the arrival of mixed flows of irregular migrants. In 2002, the government opened the Hal Far detention facility to accommodate the arriving migrants. The facility had a capacity to hold 80 persons, the assumption being that Malta would continue to receive a few hundred migrants each year. However, 1,686 migrants arrived that year and sparked the current immigration 'crisis' (interviews, UNHCR Malta Representative; Maltese MEP, July 2006).

In the years since 2002, the small island continued to see an increase in the number of migrants arriving en route from Africa: from 57 in 2001 to 1,686 in 2002 and peaking at 2,775 in $2008 .^{12}$ From 2002 to 2012 a total of 16,614 individuals had arrived by boat and 15,832 asylum applications

11 In November 2005, the government amended Article 10 of the Act to allow for the deportation of asylum seekers while their appeal against the rejection of their asylum applications was still pending (Amnesty International 2006).

12 See appendix to this chapter, table 5.1; the number of arrivals began to drop after 2008 due to the Italian-Libyan Treaty on Friendship. 
were filed; all were detained (UNHCR 2013a). At any one point, over 2,00o migrants and refugees are detained and another 2,00o held in open centres. For instance, in February 2009, there were 2,194 migrants and refugees were being housed in open centres, 766 had secured private accommodation, and 2,309 were incarcerated in detention centres. ${ }^{13}$ Although the number of arrivals is not large in absolute terms and makes up around 1 per cent of the Maltese population, the government maintains that they are more significant if one compares them to other countries taking into account population size and density. This argument is often employed in advocating an EU burden-sharing scheme and in trying to renegotiate how the Dublin II Regulation applies to the island. ${ }^{14}$

The emphasis on the number of migrants and refugees arriving in Malta reinforces the government's continual assessment and portrayal of the situation as a crisis. The argument is also questionable in light of the number of tourists who visit Malta, numbering well over one million every year, ${ }^{15}$ and other forms of migration to the island largely ignored by the government. Thus the more significant concern appears to be one of race and class, rather than the volume of arrivals. Nevertheless, the focus in Maltese debates and legislation has been on deterring irregular migrants and refugees from arriving in Malta by implementing restrictive policies, such as the island's lengthy 18 -month detention policy. This approach is fuelled and simultaneously justified by the fact that many of the migrants claim they never intended to come to Malta, nor to stay there, but were either picked up by the Armed Forces on their way to mainland Europe because they were in distress while at sea or landed on the island believing they had arrived in Sicily or Italy.

It is important to make three interrelated observations here: first, that it is politically convenient for Malta to maintain that most migrants do not want to remain on the island, a logic which helps the government to portray

13 These figures were reported in a parliamentary question (Maltese Parliamentary Question 2009 b). The numbers are difficult to ascertain as residents move in and out of the centres quite fluidly and accounts therefore vary. The fluctuating number of arrivals to the island also has a large impact on these numbers. The director of the Agency for the Welfare of Asylum Seekers, the government agency responsible for running the open centres, reported that 2,700 migrants and refugees were accommodated in January 2009 (interview, January 2009). Moreover, it is generally accepted by staff members at the open centres that more migrants live in the centres than are officially registered (various interviews, 2006-2009).

14 The arguments made are as follows: the 2,610 asylum applications that were lodged in Malta in 2008 are equivalent to almost 400,000 in France and the United Kingdom if calculated per capita. The actual asylum claims made in these countries were less than 20,000 (UNHCR 2008). 15 In 2008, an estimated 1,290,856 (National Statistics Office 2009). 
Malta as a victim of migration patterns and EU legislation; second, this focus disregards the effects of Maltese policies on migrants' desires to remain on the island; and finally, this allows the government to operate in crisis mode, ignoring global patterns which point to the likelihood that Malta and the Mediterranean will continue to be an area of transit migration in the coming years. There is also some preliminary evidence suggesting that Malta is in fact a final destination for some migrants, as was noted by the authorities in 2006 with regard to a small number of arrivals (interviews, migrants, NGOs and government officials, 2006-2009; JRS 2006: 23).

\subsection{Trying to transit: Migrant accounts and strategies}

Most of the migrants and refugees arriving in Malta come from sub-Saharan Africa, the largest percentages of asylum applicants being Somali and Eritrean over the past five years (UNHCR 2006, 2007, 2008; Luhmann, Bouhénia \& Giraux 2007). These migrants and refugees usually travel northward through Africa until they reach Libya, often stopping in countries along the way to work or apply for asylum before deciding to make the voyage across the Mediterranean. Travelling from place to place, they make use of kinship and friendship networks in order to facilitate their journeys, for example by receiving money from family members in order to pay smugglers for onward passage. These journeys often involve multiple stops where factors such as employment prospects, levels of racism and violence, perceptions of opportunities in other countries, and the possibility for future mobility influence migrants' strategies and decisions (interviews, migrants in detention and open centres, 2006-2009).

Those who arrive in Malta generally depart from Libya in order to make the voyage across the Mediterranean. In Libya, migrants and refugees spend various amounts of time ranging from days to years. Some work in order to make enough money to pay for the journey, which usually costs around $\$ 1,000$. Contrary to the assumption made by Maltese politicians and the media, migrants and refugees sometimes spend long periods of time in Libya with no desire or forethought plan to move on until push factors prompt such a decision. Many who arrived in Malta note that friends had suggested the trip, often portraying Europe as an 'el Dorado,' or that the levels of violence and racism they experienced in Libya forced them to continue on in search of personal security (interviews, migrants in detention and open centres, 2006-2009). 
Most of the trips from Libya to Malta are undertaken on the same type of small motorboat, dark in colour and approximately four metres in length. ${ }^{16}$ The boats carry between 20 and 30 people and the trips last up to seven days, during which the passengers endure extremely cramped conditions and have access to very little water and food. One person is usually elected the captain based on his ability to read a compass, which is provided before departure by the smuggler (interviews, migrants in detention and open centres, 2006-2009).

Although the migrants' destination is usually Lampedusa or Italy, adverse weather conditions or a shortage of petrol can cause migrants to be detected by the Maltese Armed Forces either by (1) patrol boats, (2) aircraft, (3) commercial vessels, (4) fishermen, or (5) phone calls from the migrants and refugees themselves who have sometimes been provided a list of contacts by the smugglers. Malta's extensive SAR region, which encompasses the Italian island of Lampedusa, and the unwillingness of states to take responsibility for migrants and refugees at sea often result in wrangling occurring taking place between countries while lives are in danger. This usually occurs between Libya, Malta, and Italy, although occasionally a fourth party is engaged when, for example, a commercial vessel is the first to encounter migrant boats in distress (e.g., MFA 2009). One refugee (interview, April 2009) in Malta recounted his experience at sea:

It was rough weather ... and we keep on asking for help. We were just two days on the sea. At the end, we managed to contact ... the Malta AFM. So there was a Russian vessel which was passing over there and they came to help us, to rescue us. When we come to speak to them, they don't want to take us from the sea as they were waiting for a reply from Malta. And then in that situation, the weather was very rough and we sink down to the sea. And we were just scattered because it was rough weather and they didn't want to help us. So, three of us they died in that moment and after two hours, we managed to be rescued by that Russian boat ... and then at the end we came to Malta.

\section{Detention}

Most boats are picked up before they ever reach Maltese shores, those aboard being subsequently transported to one of the detention centres on the island. Having gone through long and often traumatic journeys,

16 Conversely, migrants arrive less frequently, but on larger boats, in winter due to adverse weather conditions (interview, Commander of the AFM Maritime Squadron, July 2008). 
migrants find themselves incarcerated in a detention centre for up to 18 months or until their asylum application has been processed. ${ }^{17}$ In continuing with the much-criticised detention policy, the Maltese government systematically detains irregular migrants, be they refugees, economic migrants, or vulnerable cases such as minors. They thus deprive those who have committed no criminal offence ${ }^{18}$ of their freedom, portraying them as criminals and adding to the racism and xenophobia on the island. The policy is an expensive choice - one that in 2008 cost $€ 8.2$ million $^{19}$ - but one that also has profoundly negative consequences for the migrants' mental and physical wellbeing.

The two biggest centres on the islands are the Safi Military Barracks and the Hal Far Lyster Barracks, which in 2008 housed $95^{\circ}$ men and 730 people (125 of whom were women) respectively (interview, Head of Detention Services, July 2008). The number of detainees fluctuates with arrivals, having increased dramatically after 2006 (106 in Hal Far and 300 in Saf), and then fallen due to the decrease in arrivals after 2009. NGOs have deplored the conditions of detention, as detainees must endure an overcrowded and unhygienic environment within the centres. The lack of private space is palpable in some of the centres where hundreds are sometimes housed in big open rooms, some with just a mattress on the floor. The use of solitary confinement as a form of punishment and the lack of adequate outdoor access have also raised concern (e.g., ECRE 2006). A 49-year-old Iraqi man who had lived in a room with five others for 15 months described the oppressing boredom and the inhumanity of not being allowed to go outside. 'I am dead. I am finished,' he said (interview, July 2006).

The only running water available is in the bathrooms, which are communal and emit a continuous stench. Cleanliness and the spread of communicable diseases are thus of immediate concern in such confined conditions. Indeed, while the government denied requests to have the ill separated, the lack of proper facilities caused tuberculosis and other diseases to spread amongst the detainees (MSF 2009). Even a Maltese MEP

17 The time spent in detention was previously indefinite (Maltese Immigration Act of 1970). The government only established an 18-month limit after local NGO pressure resulted in a delegation being sent by the Council of Europe to investigate the matter. The Council subsequently insisted that Malta alter its indefinite detention policy. Today, asylum seekers may be released after 12 months if their claim is still pending, while rejected asylum seekers are held in detention for 18 months.

18 In 2002, Malta decriminalised the entrance without leave of its territory, but kept in place the automatic detainment of all irregular migrants upon arrival (Gil-Robles 2004: 4).

19 Up from €6.8 million in 2005 (Maltese Parliamentary Question 2009a). 
(interview, July 2006) noted, 'I myself have visited the detention centres in my own country and I am appalled at the conditions in which these people are kept ... I thought one particular centre was fit for animals and not for human beings.'

The prolonged detainment in such unacceptable conditions has severe psychological effects on the detainees. Upon entering the detention centre in the middle of the afternoon, one can find most men asleep and widespread depression is evident. Detainees report feeling as though their lives are wasted as they are reduced to total idleness with no form of physical or mental stimulation (interviews, July 2006) The Council of Europe also highlighted the lack of attention to detainees' mental health, reporting the need for on-the-spot psychiatric care, especially considering the trauma often experienced by migrants and refugees (CPT 2005).

One asylum seeker (interview, January 2009) from Darfur described the time he spent in a Maltese detention centre:

They took us somewhere and took our fingerprints and gave us a number and put us in detention. I had never been in detention before. I was very confused and didn't have a phone to call my family. It made me crazy. It is like a jail. I applied for asylum but heard nothing for three or four months. I kept having nightmares and knew that I couldn't stay in detention.

In August 2008, Médecins Sans Frontièrs (MSF) started providing muchneeded health care for irregular migrants and asylum seekers inside detention centres. Finding appalling living conditions and insurmountable structural barriers to providing adequate health care, MSF repeatedly requested that the Maltese authorities improve the conditions in detention centres. The government's inertia produced no structural changes and as a result MSF suspended their activities in February 2009, publishing a scathing report detailing the unacceptable conditions (MSF 2009).

Access to the detention centres has also been very limited. Friends and family members do not have visitation rights. Furthermore, only a few NGOs have been given access and even the press did not previously have a right to enter, except for the occasional pre-arranged 'tour' given by the government. The government maintained that this was in order to protect potential refugees and 'to protect the families and friends of detainees who are still in their homeland from retribution by the regime against which protection claims are being made' (MJHA 2005: 14). The policy was revised in 2008, allowing journalists to file requests to enter detention centres. 
Nevertheless, the effects of this policy change are ambiguous at best, as obtaining access continues to involve bureaucratic hurdles.

Despite the acknowledgement of the detainees' frustrations by most government officials, justification for the continuation of the detention policy is quick to follow. Many point to the fact that the policy attracts bipartisan support (interviews, Permanent Secretary, MJHA; Policy Advisor, Ministry for Family and Social Solidarity [MFSS], July 2006). Security concerns are also employed as a justification, as many highlight that thousands of migrants arrive every year and the government could not allow 'a huge number of persons to roam our streets undocumented without knowing their identity' (interview, Permanent Secretary, MJHA, 10 July 2006). The Minister for Justice and Home Affairs (2005: 6) maintains, 'It is therefore in the national interest, and more specifically, for the reasons concerning employment, accommodation and maintenance of public order, that a detention policy be adopted.' Nevertheless, the decrease in arrivals in 2010 has not resulted in a termination of the policy. Indeed, the Ministry of Justice and Home Affairs released a statement in December 2010 reiterating that, "The government sees no need to depart from its current detention policy, a policy which is also practiced by other EU member states' ('No need to change detention policy', 2010).

NGOs are thus highly sceptical of these justifications; detention is the major point of disagreement between the government and NGO representatives. The UNHCR and Amnesty International have repeatedly called on Maltese officials to scrap the detention system all together and set up an alternative system of open centres (interview, UNHCR representative, July 2006; Amnesty International 2008, 2006; c.f. Gil-Robles 2004: 5). Other NGO representatives emphasised the fact that detention is being used as a deterrent measure and is not in fact an administrative necessity. Indeed, the government has acknowledged that it believes the detention policy is a 'powerful deterrent' ${ }^{20}$ and has been reminded by the Committee for the Prevention of Torture (2005: 8) that international standards explicitly state that asylum seekers should not be detained in order to deter future asylum seekers, a practice which is contrary to the norms of international refugee law.

The use of detention as a deterrent hinges on several false assumptions: firstly, that migrants and refugees intend to travel to Malta when they leave Libya and view Malta as a destination country. The vast majority of migrants and refugees, although not all, report being forced to come to Malta due to 
circumstances outside of their control, such as the weather or the quality of the boat in which they were travelling (interviews, migrants and refugees, 2006-2009). Moreover, evidence from interviews with migrants and refugees in Malta suggests that despite this large political apparatus deployed to prevent mobility, a complex multitude of push factors in their countries of origin and countries of transit, as well as the perception of living standards in destination countries, are of greater consequence. ${ }^{21}$ One asylum seeker (interview, April 2009) in Malta noted:

The EU, the one thing they have to know is that it's not that Malta extending of detention length will stop people coming, no. They are people who have a problem of maybe lack of shelter, hunger, starvation, those are humanitarian issues ... For those that cannot go back, they have to give them protection ... Even if detention is ten years, people will still come.

Due to the EU pressures to reduce onward mobility and the ineffectiveness of policies aimed at deterring arrivals, the Maltese government implemented an 'assisted voluntary repatriation' (AVR) scheme in 2007. AVR is complementary to the both EU and national objectives of reducing the number of irregular immigrants in Malta, as well as removing the need to control for onward mobility to other member states. The AVR scheme began as a pilot project run from the Ministry of Foreign Affairs, which offered migrants $€_{5,000}$ and repatriated just over 100 migrants (interviews, Head of Office, International Organization for Migration; Project Coordinator, MFA, January 2009). The project has now evolved into a more permanent scheme under the auspices of the Intentional Organization for Migration. The scheme initially targeted people both in and outside of detention, but subsequently focused solely on those still inside detention. An official within the Ministry of Foreign Affairs (interview, January 2009) explained the rationale behind this emphasis:

If they are in detention they're not enjoying it for sure. In detention they can't dream, but once they are in open centres they can dream of escaping Malta ... I think detention is tough on the individual and conditions

21 I employ the terms of transit and destination countries in a fluid rather than fixed sense as travel plans change en route for many migrants and refugees as conditions change and new opportunities arise. 'Transit' countries in North Africa are often settled in for months or even years before onward travel is feasible or desirable (interviews with migrants and refugees in Malta, 2006-2009; De Haas 2007: 18-27). 
could be improved, but for us it's a blessing that people get disgusted and want to leave.

\section{Immobile in Malta: Structural and political barriers}

Having spent months in detention, irregular migrants, as well as successful and unsuccessful asylum seekers, are transferred to one of the open centres in Malta, which in 2009 housed 2,194 people (Maltese Parliamentary Question 2009a), a number that has risen significantly from 1,340 people in 2006 (interview, Policy Advisor, MFSS, July 2006). The majority of these detention and open centres are located on the southern end of the island, far from the waterfront boulevards lined with hotels that attract over a million tourists to Malta every year. The increased ghettoisation of the immigrant population hinders mobility and integration in Malta, while simultaneously encouraging hopes of onward mobility to other European countries.

The government's Agency for the Welfare of Asylum Seekers ${ }^{22}$ oversees the operation of open centres, which have also been plagued with overcrowding, causing conditions to quickly deteriorate. One of the biggest centres, which houses over six hundred people, is called 'tent city' because of the canvas tents that were erected to house migrants and refugees instead of permanent buildings. The dilapidated tents clearly provide little relief from the summer's soaring temperatures or the winter's rain and wind.

Indeed, the open centres are facing the enormous problem of overcrowding partially because the residents remain for years, without an opportunity to move on or integrate into Maltese society. The government stresses the need for open centres to be a bridge between detention and resettlement, integration or repatriation, and to this end put in place a policy to limit residence to one year (interviews, coordinators at several open centres, April 2009). This policy is short sighted, however, as it does not take into consideration the consequences of evicting migrants and refugees. As a care worker (interview, April 2009) in an open centre said, 'they have to go out ... from the perspective of this organisation, they have to go out of these doors.' A coordinator at another centre (interview, April 2009) commented, 'After he leaves here, it's not my concern anymore; it's somebody else's concern.'

In these instances, the limited and largely seasonal employment opportunities mean that people must resort to the generosity of their friends and often fall into a precarious existence when they are refused further accommodation in the open centres. Single mothers and other vulnerable

22 The Agency changed its name from the Organisation for the Integration and Welfare of Asylum Seekers in 2009, conspicuously dropping any reference to integration. 
people suffer disproportionately from the policy. Although the policy has only recently been enforced, the ultimate consequences of not providing for the genuine integration of migrants and refugees in Malta are evident (interviews, residents and coordinators at various open centres, April 2009). Indeed, the UNHCR is critical of the Maltese government for not emphasising long-term integration strategies for migrants and refugees and depending on ad hoc measures, which primarily focus on resettlement or repatriation as a solution. For instance, Malta has yet to implement a citizenship application process for refugees, and families remain in legal limbo even after years of living on the island (interview, UNHCR Malta Representative, July 2006).

The pervasive granting of temporary forms of protection rather than full refugee status also strengthens the interpretation of the situation as a temporary crisis and is detrimental to the integration process. Subsidiary protection does not allow for family reunification and also may be revoked if the government deems that a country of origin is safe for return. Although the government claims it has one of the highest protection rates in Europe (MJHA 2005:5) and has indeed given some form of protection to between 40 and 60 per cent of asylum applicants between 2004 and 2008, temporary forms of protection are granted to the vast majority. The refugee recognition rate, which is in any case minimal, has declined steadily over four years, from 4.9 per cent of applicants in 2004 to less than in 1 per cent of applicants in 2007 and $2008 .^{23}$

Consequently, integration proves more difficult and many attempt to leave Malta permanently, travelling to other member states within the European Union on tourist visas (interviews, migrants and refugees in Malta, 2008-2009). However, the Dublin II Regulation and the Eurodac, an EU database that holds the fingerprints of all irregular immigrants and asylum seekers, extends Maltese border controls throughout the EU and thus cause further immobility for migrants and asylum seekers. Once in another member state, the stipulations under the Regulation compel these migrants and refugees into an irregular existence, as entering official bureaucratic channels such as asylum processes can result in apprehension

23 See appendix to this chapter, table 5.1; calculations are based on the number of people who have had their asylum claim processed during one year, either receiving some form of protection or being rejected. The number is not necessarily equal to the number of applicants who lodge their claims during one year as the Refugee Commissioner's Office has experienced severe delays in processing these claims since its creation in January 2002 (interview, Refugee Commissioner, July 2006; statistics provided to the author by the Refugee Commissioner, April 2009). 
and repatriation to Malta. ${ }^{24}$ Many, having been returned from as far away as Norway or the UK, despair that they will remain on the island indefinitely, unable to continue their journey or be reunited with their family because, as they explain, 'Malta has my finger.'25

A young man from Darfur (interview, January 2009) with subsidiary protection recounted his attempts to leave the island and make a life for himself elsewhere:

I escaped from Malta to Italy and again the situation was very bad and I didn't know anybody there. I was caught by the police and fingerprinted and sent back to Malta. The police there told me it was because of EU regulations ... I made some money and booked a ticket to Switzerland, but wanted to go to England. So, I crossed into France and spoke to some people there who told me I should go to Calais. I went to Calais and was told to get into a lorry, but we didn't know if the lorries would go to England or not. But me and another guy got into a lorry with lots of boxes in it and spent five hours inside while the lorry got on a ship and then went to England. I was caught in England and fingerprinted. I spent three days in a police station and then they sent me to a hostel where I spent two months. Then one day I got a letter from the Home Office and went to Croydon. They told me I had to go back to Malta because of EU regulations. I told them I didn't want to go back, that there was nothing for me in Malta. If you go somewhere how can you survive if they have your fingerprints?

\subsection{Conclusion: Transit migration?}

In concluding, it is fitting to revisit the concept of transit migration and to assess, in light of these migrant experiences in Malta, whether one can classify the immigration phenomenon that occurred on the island between 2002 and 2013 as such. From a general, macro perspective, one might do so. After all, the time period saw migration flows increase across the central Mediterranean, in part a response to the increased fortifications along more

24 Although the number of Dublin II returns to Malta are low in absolute terms (127 in 2006, 37 in 2007,131 in 2008 and 470 in 2009), the limited data available suggest an increase over these three years (2006 figures: Commission of the European Communities, 2008; other figures provided by the MJHA to the author, January 2010).

25 A statement repeated by many migrants in Malta with subsidiary protection (interviews, April 2009). 
western routes to Europe through Morocco, Ceuta, Melilla, and the Canary Islands. Indeed, in Malta, many migrants continue to express their desire to move northward towards Italy and even further into Europe.

However, as one homes in on the individual's perspective, the concept appears less helpful, unless we take a very broad, and thus less meaningful, definition of transit migration. Migrants certainly transit various countries during their journey. However, these transitions are often not pre-meditated, as migrants must adapt to the barriers and opportunities they encounter en route. This thus raises questions of a temporal nature. If a migrant remains in Malta for many years, finding employment and integrating into Maltese society relatively well, before being resettled to another country, is this transit migration? And if so, is it useful to include such an experience in a category that also includes those who pass through the island, remaining only for a matter of days or months before moving on to Italy?

What is made clear by this Maltese case study is that migrant agency must be considered within the context of structural barriers and opportunities to mobility. Indeed, despite the large political apparatus deployed by the government to both deter arrivals in Malta and limit integration opportunities, migrants and refugees did arrive and many have remained. The government's rhetoric and policies are partially successful in conditioning the interests of migrants and refugees by limiting the expectations they have in terms of integration and access to rights on the island. This indirectly encourages many to migrate irregularly to other EU member states. However, other migrants and refugees have carved out small spaces for themselves within Maltese society, embarking upon the integration process through their own efforts.

Moreover, whilst in 2010 the Libyan-Italian Treaty on Friendship briefly interrupted the immigration flows to Malta, these were resurrected again after the fall of the Gadaffi regime in 2011 and in the first six months of 2013600 individuals had landed on Malta (UNHCR 2013b). The increased migration through Turkey and Greece also suggests that these flows have been rerouted rather than prevented. The arrivals in Sicily and Lampedusa in early 2011 on the heels of the political upheavals in North Africa also indicate that migration across the Mediterranean remains feasible, albeit more dangerous. These developments highlight the adaptability of migration flows and their persistence.

The Maltese case study also reveals how a government may employ the notion of being a transit migration country to its political benefit. The government maintains that migrants and refugees are trapped in Malta, and that its hands are tied by EU legislation on the matter. Although there 
is some truth to these claims, as is made clear in the section above, the government has exploited this rhetoric in order to justify inhumane policies and to appeal to the EU for more support. The emphasis has thus been on the short term, on restrictive policies such as deterrence and repatriation, rather than long-term integration.

EU membership has facilitated this emphasis on exclusion and influenced the repressive elements of policy, ${ }^{26}$ especially through the redefinition of Maltese borders as external borders. As Malta continues to stress the need for burden-sharing initiatives, the government continues to treat migration to the island as a crisis and seems unwilling to accept its new role as a country of immigration. Indeed, this portrayal is often exploited in order to attract more EU support. This mentality results in the adoption of ad hoc policies in a reactive, rather than proactive approach, with little long-term strategy. The short-term focus on deterrent policies disregards the reality of continued migration between Africa and Europe and fuels the xenophobic attitudes so prevalent in Malta already. Moreover, although deterrent policies implemented in other countries have had limited success (Boswell 2003:27), more progressive and creative approaches to migration are not being discussed.

What is apparent is that new strategies need to be employed to respond to the new migration patterns that Malta is facing, especially in its new capacity as an EU member on an external border. As a signatory to the 1951 Geneva Convention, the island has a responsibility towards those seeking asylum on its shores. Moreover, the human dignity and human rights of all migrants should be upheld and should be at the forefront of the political dialogue on immigration. Migrants and refugees ought to be empowered and given the opportunity to contribute positively to the Maltese economy and culture, rather than being locked up like criminals. In attaining these goals, the EU should obviously move towards policies that do not discriminate against member states on the periphery and that allow for a focus on legal migration and asylum provisions rather than draconian restrictions. For Malta, the most fundamental step is to move beyond treating immigration to the island as a crisis and to accept the new reality with more positive rhetoric and policies.

26 For a broader discussion of how Southern European migration policies have been influenced by the EU, see Geddes 2003: 157-172. 


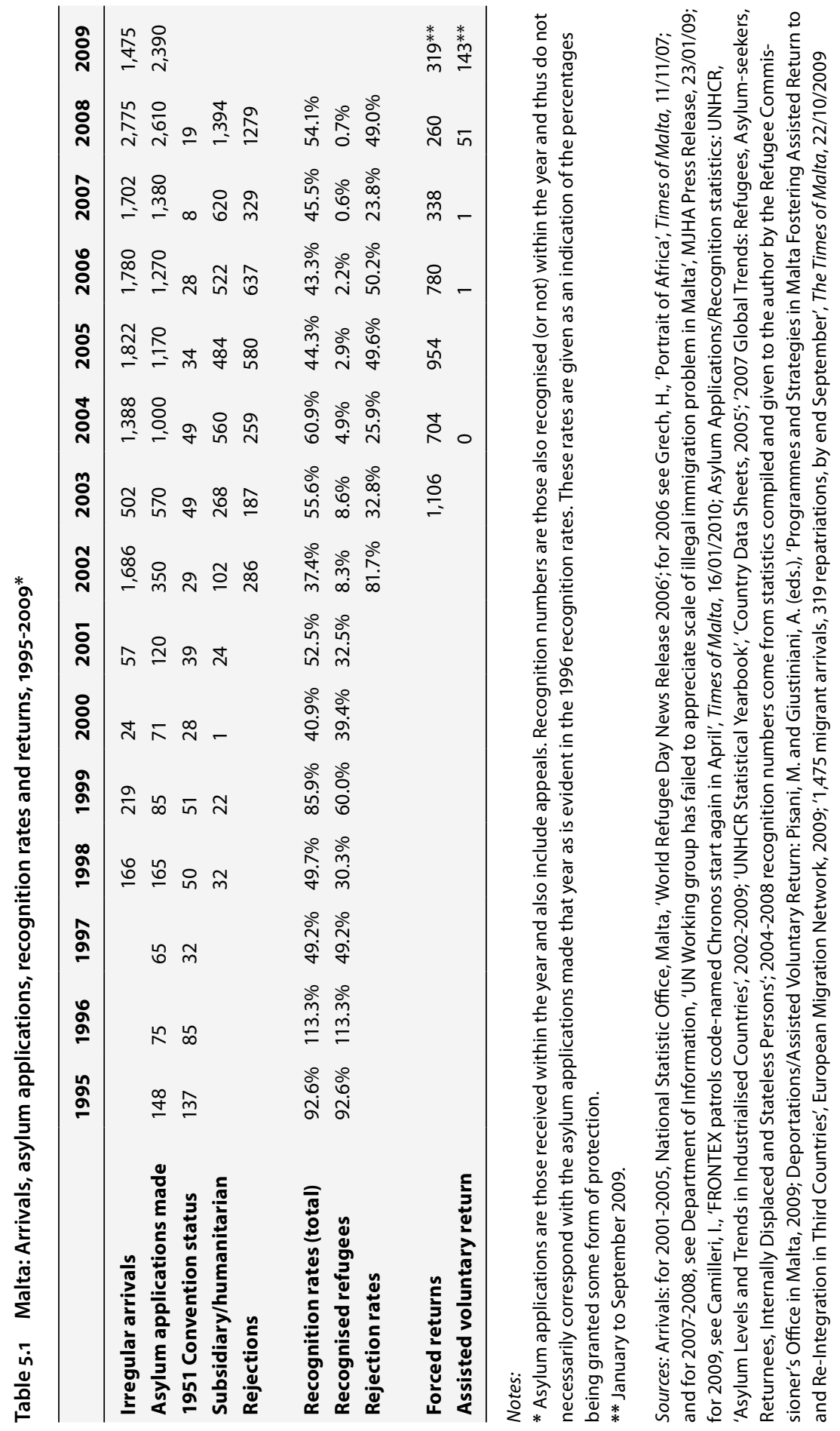




\section{References}

Amnesty International (2006), Malta:Amnesty International Report 2006. Amsterdam: Amnesty International.

Amnesty International (2008), Malta: Amnesty International Report 2008. Amsterdam: Amnesty International.

Andrijasevic, R. (2006), 'How to Balance Rights and Responsibilities on Asylum at the EU's Southern Border of Italy and Libya'. Working Paper No. 27. Oxford: University of Oxford Centre on Migration Policy and Society (COMPAS).

Baldwin-Edwards, M. (2004), 'The changing mosaic of Mediterranean migrations', Migration Information Source June: 1.

Bilefsky, D. (2007), 'Malta lashes out at EU migration policies', International Herald Tribune 4June.

Boswell, C. (2003), European Migration Policies in Flux: Changing Patterns of Inclusion and Exclusion. Oxford: Blackwell Publishing.

Camilleri, I. (2008), 'FRONTEX chief admits failure', Times of Malta 21 September.

Commission of the European Parliament (2008), 'Impact assessment accompanying the proposal for a regulation of the European Parliament and of the Council establishing the criteria and mechanisms for determining the member state responsible for examining an application for international protection lodged in one of the member states by a third-country national or a stateless person', Commission Staff Working Document, SEC (2008) 2962, 3 December.

Committee on the Prevention of Torture (CPT) (2005), 'Report to the Maltese government on the visit to Malta carried out by the European Committee for the prevention of torture and inhuman or degrading treatment or punishment from 18 to 22 January 2004'. Geneva: CPT.

Crisp, J. (2003), 'A new asylum paradigm? Globalization, migration and the uncertain future of the international refugee regime', UNHCR New Issues in Refugee Research Working Paper No. 10o. Geneva: UNHCR.

Cuttitta, P. (2007), 'The changes in the fight against illegal immigration in the Euro-Mediterranean area and in Euro-Mediterranean relations', The Changing Landscape of European Liberty and Security (CHALLENGE), Working Package 8, Working Paper Month 24.

De Haas, H. (2007), The Myth of Invasion:Irregular Migration from West Africa to the Maghreb and the European Union. International Migration Institute Report. Oxford: University of Oxford.

European Council (2008), 'Report on the Implementation of the European Security Strategy: Providing Security in a Changing World', S407/08, Brussels, 11 December.

European Council on Refugees and Exiles (ECRE) (2006), ECRAN Weekly Update, 27 July.

European Council on Refugees and Exiles (ECRE) (2011), ECRAN Weekly Update, 11 February.

European Parliament (2010), What System of Burden-Sharing between Member States for the Reception of Asylum Seekers? Directorate General for Internal Policies, Policy Department C, Citizens' Rights and Constitutional Affairs, Civil Liberties, Justice and Home Affairs: PE 419.620, 22 January.

FRONTEX (2009), 'HERA 2008 and NAUTILUS 2008 Statistics'. Warsaw: FRONTEX.

Geddes, A. (2005), 'Europe's border relationships and international migration relations', Journal of Common Market Studies 43 (4): 787-806.

Geddes, A, (2003), The Politics of Migration and Immigration in Europe. London: Sage Publications.

Gil-Robles, A. (2004), 'Report by Mr Alvaro Gil-Robles, Commissioner for Human Rights, on his visit to Malta, 20-21 October 2003', Office of the Commissioner for Human Rights, Council of Europe, Strasbourg.

Haynes, M. (1999), 'Setting the limits to Europe as an "imagined community"' in G. Dale \& M. Cole (eds), The European Union and Migrant Labour. Oxford: Berg. 
House of Lords (2004), 'Handling EU asylum claims: New approaches examined', European Union Eleventh Report, HL74, 30 April.

Human Rights Watch (2006), Stemming the Flow:Abuses Against Migrants, Asylum Seekers and Refugees, 18 (5), September.

Human Rights Watch (2009a), 'Italy/Libya: Forced return of migrants violates rights', 7 May.

Human Rights Watch (2009b), 'Italy: Berlusconi misstates refugee obligations', 12 May.

Jesuit Refugee Services (JRS) (2006), Asylum in Malta: What You Should Know. Rome: JRS.

Katrougalos, G. \& G. Lazaridis (2003), Southern European Welfare States: Problems, Challenges and Prospects. Basingstoke: Palgrave Macmillan.

Luhmann, N., M. Bouhénia \& F. Giraux (2007), Access to Health Care and Human Rights of Asylum Seekers in Malta: Experiences, Results and Recommendations. Paris: Médecin du Monde.

Lutterbeck, D. (2006), 'Policing migration in the Mediterranean', Mediterranean Politics 11 (1): 59-82.

Maltese Parliamentary Question (2009a), 'Detention centres: Spiża totali', Legislature XI, no. 6959, 11 March.

Maltese Parliamentary Question (2009b), 'Immigranti illegali detenuti fić-c்entri ta' detenzjoni', Legislature XI, no. 6527, 23 February.

Médecins Sans Frontières (2009), “'Not Criminal”: Médecins Sans Frontières exposes conditions for undocumented migrants and asylum seekers in Maltese detention centres', April.

Ministry for Justice and Home Affairs (MJHA) (2005), Irregular Immigrants, Refugees and Integration: Policy Document. La Valetta: MJHA.

Ministry of Foreign Affairs (2009), 'Ministerial statement regarding the immigrants who were rescued by the M/V Pinar-E off Lampedusa', Press Release, 21 April.

National Statistics Office (2006), 'World Refugee Day 2006', Malta.

National Statistics Office (2009), 'Departing tourists: December 2008', 27 January, Malta.

Noll, G. (2003), 'Visions of the exceptional: Legal and theoretical issues raised by transit processing centres and Protection Zones', European Journal of Migration and Law 5 (3): 303-341.

Schuster, L. (2005), 'The Realities of a New Asylum Paradigm'. Working Paper No. 20. Oxford: University of Oxford Centre on Migration Policy and Society.

Times of Malta (2010), 'No need to change detention policy, Justice Ministry insists', 10 December. Townsend, M. (2008), 'Libya key transit for UK-bound migrants', The Guardian 13 January.

Triandafyllidou, A. (2008), 'Controlling migration in Greece: Policies, problems and opportunities', Real Instituto Elcano, ARI 35/2008, April.

Triandafyllidou, A. (2001), Immigrants and National Identity in Europe. London: Routledge.

UNHCR (2006), 'Asylum levels and trends in industrialized countries'. Geneva: UNHCR.

UNHCR (2007), 'Asylum levels and trends in industrialized countries'. Geneva: UNHCR.

UNHCR (2008), 'Asylum levels and trends in industrialized countries'. Geneva: UNHCR.

UNHCR (2009a), 'Mediterranean Sea arrivals: UNHCR calls for access to protection', 9 January. Geneva: UNHCR.

UNHCR (2009b), 'UNHCR deeply concerned over returns from Italy to Libya', 7 May. Geneva: UNHCR.

UNHCR (2013a), 'UNHCR'S position on the detention of asylum-seekers in Malta', Geneva: UNHCR, available at www.unhcr.org.mt/news-and-views/news/698.

UNHCR (2013b), 'Some 8,400 migrants, asylum-seekers reach Italy and Malta by sea in first half of 2013', News Stories, 5 July. Geneva: UNHCR. 

Part 2

The Central and Eastern European Quadrants 



\title{
6 The East-to-West Circuit
}

\author{
Transit Migration through Russia
}

Irina Ivakhnyuk

\subsection{Introduction}

For over a decade, from 1990 to 2000 , Russia went through a period of economic downturn and contraction. This was related to the disintegration of the Union of the Socialist Soviet Republics (USSR). Transformations such as these, combined with new transportation facilities, impacted, changed and re-directed international migration routes. Correspondingly, new migration routes emerged which resulted in particular countries being transited by migrants. In the early 1990 s these new routes were rapidly established and the vast territory of the formerly closed USSR was increasingly used by transit migrants and smugglers of migrants. Since then, numerous transit routes have run through the territory of Russia and the country has provided a convenient and cheap land route for Asian and African migrants on their way to the West. From 2000 to 2008 , Russia benefited from rising oil prices, windfall profits and an increase of investment in many sectors. This generated a period of economic growth which in turn resulted in a considerable demand for migrant labour. Consequently, Russia also became attractive as a destination country for immigrants. The economic crisis in 2008-2009 then slowed down the demand for immigrant labour, although this is likely to increase again with economic recovery. Nevertheless, as this contribution will show, transit migration continues and sometimes overlaps with immigration.

The case of Russia is a good example of the complex profile of a country that is both an attractive destination and a popular transit zone for migrants. Indeed, Russia exemplifies the full spectrum of this phenomenon. Therefore, this case study illustrates a variety of effects and contradictions of contemporary transit migration.

First, the geopolitical position of Russia situated between Europe and Asia makes it a convenient transit corridor for migrants moving from east to west. Second, transit migration in Russia takes place primarily in an irregular form with all the corresponding negative effects for the country and the migrants themselves. Third, migrants who are supposed to be in transit often become long-term or even permanent immigrants to Russia. Fourth, 
an informal 'migration infrastructure' (ethnic social networks, criminal smugglers' networks) has emerged and facilitates many types of migration. Fifth, authorities often remain passive, corruption is widespread, and the law is not enforced, which results in favourable conditions for irregular transit migration. Sixth, transit migrants' rights are often violated under the existing legislation. And seventh, transit migration in Russia can be explained through social capital theory and in particular with those aspects that refer to migrants' networks, for example, the 'sets of interpersonal ties that connect migrants, former migrants and non-migrants in origin and destination areas through ties of kinship, friendship, and shared community origin' (Massey et al. 1993: 448).

Russia is at the centre of the Eurasian international migration system and, consequently, its policies have to address transit migration and protect migrants in transit. This chapter focuses on migrants transiting Russia with the aim to move west, but not migrants transiting other countries, heading for Russia. Due to a lack of more recent data, it focuses on and compares the 1990s with the 2000s, though it is suggested that most findings hold true to date.

\section{Data and methods}

This chapter presents the results of several surveys of international migration that were recently carried out in Russia and that provide data for an analysis of migrants in transit (Ivakhnyuk 2005a, b; Krasinets 2006; Kozina, Karelina \& Metalina 2005; IOM 2004). In particular, two surveys are utilised for the purpose of this chapter. The first survey of transit migration was conducted in 1994 by the International Organization for Migration (IOM 1995) focusing on Moscow and Saint Petersburg (233 interviews). A second survey on migration flows from Asian countries to Russia was conducted in 2001 by the Centre for Political Information (2002) focusing on Moscow (203 interviews). No more recent survey is available. Both used similar methods: survey interviews on the streets, at metro stations, the Central Telegraph Office, the UNHCR Moscow Office, hostels, in the transit zone of the Moscow Sheremetyevo International Airport, the UNHCR temporary accommodation centre for transit migrants, as well as in-depth interviews in focus-groups (students, Afghans, Chinese, Somalis, and Kurds). Therefore, their results are more or less comparable. They demonstrate a shift in transit migration characteristics in Russia at the beginning of the 2000 s when compared to the beginning of the 1990s. Other surveys conducted in some neighbouring countries provide further information on patterns of transit migration in the region (IOM 2006; Pribytkova 2007; Gromovs 2007). In 
addition, information is provided by studies of Chinese migration, notably the results of the Moscow Chinese ethnic community survey conducted in 1998 (428 interviews) and Gelbras (2001). Academic and government experts in international migration in Russia were also interviewed and informal discussions with Afghan and Vietnamese community representatives in Moscow were held. Finally, migration data from official publications was consulted, such as the National Statistics Committee of the Russian Federation (ROSSTAT), the Ministry of Interior, the Border Service, and the Federal Migration Service (FMS).

\section{Problems of defining transit migration: The Russian experience}

The conventional understanding of transit migration is that it is a short-term temporary stay of a migrant on his/her way from a country of origin to a country of destination. However, this has been challenged by evidence from countries of transit. Typically, it was assumed that transit migrants aimed to keep their stay in a transit country as short as possible, as they are eager to move on to a destination country as quickly as they can. However, in reality entry to major destination countries is complicated by strict migration regulations, visa limitations, and financial requirements. For many would-be migrants, direct air flights to a European capital city turn out to be impossible or bear high risks of being refused entry and immediate removal. For these reasons, people on the move often choose strategies which are more complex in terms of distance and time, and more uncertain in terms of security and routes through other countries. Usually these choices involve irregular practices. For instance, migrants often resort to the assistance of professional smugglers who propose transit routes based on geographical considerations, gaps in the migration and border control system, and availability of transport facilities.

As a consequence, a stay in a country en route is not necessarily 'shortterm'; indeed, with respect to irregular transit migration, in most cases it is not short-term. Instead, migrants aiming only to transit a country may change their intentions under certain circumstances or after a certain period of stay in a country of transit: they may decide to stay for a longer period in order to earn money or to work out a better strategy for their migration project.

Migrants' strategies to reach the desired EU country or other developed country are very diverse. They use various legal and semi-legal methods, often conceal their real intentions, develop multi-stage migration strategies, and respond flexibly to opportunities so as to succeed in their intention. In accordance with these strategies, a long-term stay in a transit country 
becomes a common occurrence. Thus, the conventional definition of transit migration turns out to be inappropriate, as its duration varies depending on migrants' tactical purposes. For example, can a Chinese student be regarded a transit migrant when he or she migrates to Moscow to obtain a university degree, with the aim to move on to an EU country? Such a five-to-six-year stay in Russia hardly corresponds with the conventional understanding of transit migration. However, the student sees him/herself as a temporary migrant, considers the stay in Russia as a transitory affair and the education and skills obtained as an advantage in moving on to the desired country. Some foreign students are even more strategically oriented: their declared intent is to come to Russia for the purpose of attending university, but in fact they only use their student visa and student card to stay legally in Russia in order to prepare their onward migration to the EU.

Often, transit migration in Russia is considered on a par with irregular migration. This is because foreign nationals may regularly enter the country of transit but then over-stay their visa. For instance, the purpose of arrival declared by migrants when they apply for a visa or at the border crossing points is often suspected not to correspond to their real intentions. In 2009, 282,368 persons entered Russia declaring 'transit' to be their purpose; of these, 59,093 persons entered from the territory of Kazakhstan (see annex to this chapter, tables 6.2 and 6.3). This is 0.3 per cent of the total number of arrivals of over 20 million. Simultaneously, over 60 per cent of arrivals were classified as 'private visits'. However, the Deputy-Director of the Federal Migration Service of Russia, Vyacheslav Postavnin, believes that what is declared by non-CIS citizens entering the Russian Federation as a 'private visit' is often a stay in Russia with the intention to prepare onward migration to Europe (interview with Postavnin, 18 December 2007). Certain tourism bureaus and other mediators are specialised in providing false invitations and other supporting documents (Ivakhnyuk 2005b; IOM 2004). Hence, in political terms, the main challenge of transit migration arises not from those travellers who declare 'transit' as the purpose of their entry, and who submit supporting documents, but from those who conceal their real intentions, enter the territory of Russia, abscond from immigration control and arrange irregular onward journeys.

From the data on transit migration for 2006-2009 (annex to this chapter, table 6.1), two trends become apparent: (1) the numbers of entries of transit migrants permanently exceed the numbers of their departures; (2) the steady decline in the scale of transit migration through Russia. Surveys of irregular migration in Russia suggest that the majority of the migrants from non-CIS countries are transit migrants whose aim is to reach the EU. 
Often, however, they stay in Russia for months and even years, usually with an irregular status, in order to earn their living and accumulate some money for the next step in their migration. In this context, the shadow economy in Russia, according to Radaev (1999: 10), represents a quarter of the GDP and 15-30 per cent of the total labour force, offering plenty of earning opportunities. It is assumed that many transit migrants wittingly choose land routes via Russia and stay in the country for some period of time as this offers them the advantage of possible earnings in order to finance their onward migration.

In order to overcome the usually restrictive immigration policies of destination countries, people who intend to move to another country are often compelled to resort to the help of professional mediators or smugglers. Some sources suggest that up to 75 per cent of illegal entries to developed countries are presently realised with some assistance from human smugglers and traffickers (IOM 2003, 2006). The human smuggling business often goes beyond the simple crossing of state borders and includes briefing migrants on how to answer officials' questions, how to dress, and how to avoid raising the attention of the authorities.

Summarising all the peculiarities of a migrant's transit journeys and taking into account their human, economic, social and security dimensions, one can say that international transit migration is migration of persons from a country of origin/departure to a country of destination/settlement through an intermediate/transit country, often in uncertain or insecure conditions. Under certain conditions (voluntarily or involuntarily) the country of transit can either be a staging post before irregular entry to another, often more prosperous, country, or the place of an irregular and relatively long-term stay and irregular employment, or even a country of permanent residence when further migration appears impossible and a return to the country of origin is considered too high a risk.

\subsection{The emergence of Russia as a transit zone}

Since the early 1990s, the territory of the formerly closed Soviet Union has increasingly been used by transit migrants and the smugglers of migrants. It appeared to be a relatively comfortable and cheap land route for migrants from Asia and Africa on their journey to more developed states of the European Union. Therefore, Interpol considered the Russian Federation and Ukraine to be important transit zones for migrants smuggled to the EU (Interpol 2010). The question is why Russia is used by migrants from Asia 
and even Africa on their way to the European Union? Russia's geographical position and common land border with European countries is the most obvious but still insufficient explanation.

As early as in the first half of the 199os, soon after disintegration of the USSR, several features that facilitate transit migration began to take shape and transformed Russia into a transit corridor:

- Poorly managed and relatively porous new international borders in what was once coherent Soviet territory facilitated the emergence of various east-to-west transit routes and guaranteed flexibility in the choice of itineraries depending on individual situations.

- Relatively liberal regulations of travel between the Commonwealth of Independent States (CIS) and the former socialist countries of Central and Eastern Europe (CEE) coincided with relaxation of travel between $\mathrm{CEE}$ and EU countries and resulted in new easy paths to West European countries.

- A lack of proper legal controls on the stay of foreign citizens in the Russian Federation enabled migrants to abscond and stay irregularly throughout their transit period, regardless of its duration.

- Russia lacked the institutional capacities to manage migration; this was reinforced by a high level of corruption in the sphere of migration management (Mukomel 2005).

- Huge informal labour markets provide employment and earning opportunities for migrants, whatever their intention.

- Numerous ethnic networks exist of migrants from developing countries who in earlier periods arrived and settled in the USSR, for instance as refugees from political persecution or war, or being graduates from Russian universities and other higher education institutions.

- Finally, the ratification of the UN 1951 Convention on Refugees by Russia in 1993 attracted thousands of asylum seekers from developing countries who - even when they had no intention of gaining refugee status in Russia - used the refugee law to obtain temporary legal status in this transit country.

Over the course of time, the majority of West European states tightened their entry regulations. However, there is no evidence for a decrease in the number of transit migrants from China, Afghanistan, Vietnam, or Ethiopia in the region. This means that they seem to have adapted to the new situation of a more 'complicated transit'. Due to these conditions, transit migration is mostly irregular in character, more extended in time, and more expensive because of increased bribes and fees for forged papers, 
and the rising costs associated with multi-step journeys of migrants, westward.

Refugees from distant and war-stricken countries like Ethiopia, Somalia and Iraq, who believe they have grounds to apply for asylum in an EU country, often choose lengthy land routes via Russia on their way to Europe. They prefer not to apply for refugee status in Russia but in developed states where living standards are higher, social assistance is guaranteed and human rights' protection is an issue of priority. Members of the Afghan diaspora in Moscow explain that preferred destinations include Sweden and Denmark (IOM 1995; Centre for Political Information 2002). This is for two reasons: first, because rules for asylum seekers are perceived to be most liberal in these countries; and second, once a legal status is obtained they believe that refugees can apply for reunification with their other family members. Consequently, funds for travelling to Europe are often collected from relatives who later intend to follow the 'pioneer migrant' (IOM 1995: $46,48)$.

Migration to Russia is mainly controlled by two agencies, the Federal Migration Service (FMS) and the Border Service under the Federal Security Service (FSB). The FMS mandate is to implement the state migration policy and to issue residence permits, work permits to foreign citizens, as well as travel documents to Russian citizens, and to conduct immigration control. One aspect of the latter mandate is to set up control posts at international airports, railway stations and other border crossing points, and randomly to check foreigners. The task of the Border Service is to control entry/departure at the border, checking documents and their validity.

A significant difference is noted in the quality of border control at the eastern and western border frontiers of the Russian Federation. Control on the eastern borders is far less efficient than in the west; this phenomenon is conceptualised as 'asymmetric borders' (Krasinets, Kubishin \& Tiuriukanova 2000; Krasinets 2006; Vitkovskaya 2002). The consequence is that it is much easier for a migrant to enter Russian territory from the east and south than to depart to the west. If a migrant who aims to transit the country loses his regular status while staying in Russia, $\mathrm{s} /$ he has to use irregular ways to cross Russia's western frontier, notably with either forged or invalid travel documents, without any documents or by corruption. However, Russian border guards frequently prevent attempts at illegal exits (interview with the Deputy Head of the Russian Border Service Vladimir Troufanov, 27 May 2006). In this case irregular transit migrants are forced to stay in Russian territory; as a consequence the country has become a sort of 'reservoir' for irregular migrants. 
Initially, during the mid-199os, migrants from non-former-Soviet Union states consisted primarily of three equally large groups:

1 immigrants who arrived for economic reasons and did not fall under refugee status (Bangladeshis, Chinese and Vietnamese);

2 immigrants who continued to stay in Russia either after graduating from Russian universities and other further education institutions or after the expiry of their work contracts;

3 refugees who were granted asylum in Russia before the collapse of the USSR (Somalis and those Afghans who were supporting the socialist government and were forced to leave their country once the Soviet troops were withdrawn).

A few years later, a fourth group was noted: migrants who explained that they chose Russia as a transit country on their way westward. According to a study conducted by the Centre for Political Information (2002), around 25 per cent of the respondents, notably a third of the migrants from Africa and Middle East, fell into this group.

However, it is not only for migrants from distant countries that Russia has become a transit corridor and gateway to Europe. Irregular migrants from former Soviet Union states who aim to migrate to EU countries also often use Russia as a transit area. Experts from Central Asian states argue that the true purpose of 10-2o per cent of migrants from Uzbekistan, Kazakhstan and Kyrgyzstan to Russia is to reach an EU country and to open up a path for their family (e.g., Olimov 2009). They believe that in contrast to their own countries, they have a chance to earn the money they need in Russia for their move to the West. Additionally, they hope to gain experience in managing an irregular migration status while still living in relatively familiar conditions characterised by a common language, similar labour traditions and other conditions. However, it is difficult to distinguish them from the irregular labour migrants from post-Soviet Union states in Russia and identify those who aim to move west.

\section{Stocks and flows of transit migrants}

It is a complex task to estimate numbers of irregular transit migrants. This is for a number of reasons. First, transit migration is often clandestine and irregular in nature. Second, the distinction between transit and non-transit migrants within the stock of irregular immigrants is unclear. Third, data on the detention of irregular migrants on Russian territory are compiled by the Ministry of Interior, whilst data on the numbers of persons apprehended for crossing the borders are compiled by the Border Service. These data are, 
however, not published; data from the Border Service, which is a part of the Federal Security Service, are not normally publicly available, therefore no reference can be given. In 2005, according to the Border Service, over 8,000 persons were apprehended as trespassers at the Russian Federation borders while 65,00o persons were not allowed to enter Russia at the border crossing points due to invalid documents. Data of the Ministry of Interior show that in the same year, over 200,00o foreign citizens and persons without citizenship were penalised for expired visas. About 1,400 persons were apprehended while attempting to depart from Russia with false documents, among them 184 persons from Bangladesh, 154 from Turkey, 151 from Sri Lanka, 141 from India, 51 from China and 49 from Pakistan.

Between 1999 and 2005, over 500 organised groups of human smugglers were detained; additionally 16,200 tourist agencies were penalised for human smuggling in 1998, 6,300 in 1999, 7,100 in 2000 and 8,900 in 2001 (Ministry of Interior, unpublished source). In 2004, the Federal Migration Service control posts at the border crossing points randomly checked 4.9 million foreigners entering Russia, about 20 per cent of all foreign entries. As a result, over 15,000 persons were prohibited from entering; of these 2,500 persons had invalid documents, but the majority was refused because the declared purpose for their entry did not match the real purpose. In the same year, 12,200 persons who were already on the territory were deported (Ministry of Interior, unpublished annual report).

The Russian Federation Ministry of Interior suggests there are at least half a million transit migrants from Afghanistan, China, Angola, Pakistan, India, Sri Lanka, Turkey, Ethiopia and other countries who are 'stuck' in Russia (Centre for Political Information 2002). In contrast, the Federal Border Service argues that there are around 1.5 million illegal transit migrants from Southern and Central Asia and Africa on Russian territory (ICMPD 2006). This number includes persons who have entered Russia legally, with a visa and declared transit as the purpose of their entrance to the country but whose departure was not recorded. Besides, there could be a significant flow of migrants who irregularly penetrate Russian borders trying to reach EU countries, going unnoticed and not covered in any reports.

Data from the Federal Border Service of the Russian Federation on entries and departures of foreign citizens demonstrate the scale of international movements and their structure, by declared purpose of travelling (annex to this chapter, tables 6.1, 6.2 and 6.3). These imply that in 2009, citizens of Ukraine and Kazakhstan used the territory of Russia for transit most actively. South Korea and China stood out among non-former Soviet states. However, as was noted earlier, it should be taken into consideration that 
'transit' being declared as a purpose of entry is not the only channel for transit migrants. Certain migrants who indicated their arrival was 'for private purposes' or 'tourism' may have in fact had hidden or uncertain intentions, such as those of moving further to the West.

\section{Factors, channels and routes}

Previous surveys of migrants in Russia in 1994 showed certain forms of stress - wars, pogroms, fear for children's welfare, ethnic tension and discrimination or political persecution - were the most common push factors (IOM 1995). Over half of all migrants indicated escaping stress factors as a key motivation for their migration. Another important factor was education (15 per cent), often in combination with stress factors. As regards migration from Afghanistan and former Soviet republics, stress factors were the only determinants for migration. But with respect to migration from Africa, the Middle East and South-East Asia, stress factors were partially complemented by the aim to study. Economic push factors were dominant only for Chinese, Vietnamese and migrants from other South Asian countries. Only 17 per cent of Africans, 25 per cent of Vietnamese and only 5-6 per cent of Afghans and Kurds were prepared to consider return and many respondents argued that returning home was impossible (IOM 1995). This demonstrates that at that time, migration to Russia was primarily forced migration.

By the beginning of the 2000s, economic push factors had become more important, especially for migrants from CIS states. The majority, 77 per cent, noted 'lack of economic opportunities' as the major reason for emigration. Still, however, over a quarter of migrants explained their choice of Russia due to the belief that 'it is easier to obtain refugee status' there (see annex to this chapter, table 6.5). Meanwhile, the 'student channel' was also widely used to enter Russia, notably by 30-40 per cent of migrants from Africa, South-East Asia, and the Middle East. ${ }^{1}$ At the same time, only half of those migrants who declared studies as the purpose of their arrival did actually become students. The majority of migrants from Afghanistan and Middle East countries who used the 'student channel' to enter Russia had relatives there and came to join their families. This was often a step to further migration to the West.

It is noteworthy, however, that for migrants who wished to move on to another country, disillusionment with living standards and tolerance in

1 Official data from ROSSTAT differ from those from sociological surveys, however, employment and studies are also the most important reasons to come to Russia (see annex to this chapter, table 6.4). 
Russia have become the most significant push factors. Indeed, 70 per cent of the informants stated that they would never advise their compatriots to immigrate to Russia (Centre for Political Information 2002). Among migrants from former Soviet republics the percentage of 'disillusioned' is also high, though they were better informed about living standards in Russia prior to their arrival and therefore less surprised and disappointed. The main disappointment was the reserved reception by Russian authorities, the lack of support and general attitude towards them as being 'second class'.

According to Interpol (2010), the major routes of irregular transit migration, often facilitated by smugglers, generally ran from South-East and South Asia through post-Soviet states in Central Asia or the Caucasus, and on through Russia and Ukraine to the European Union. Russian law enforcement bodies have detected the following transit routes (IOM 2002: 37-38), and it can be assumed that many are still active:

- Middle East/South-East Asia - Turkey - Georgia/Armenia/Azerbaijan Moscow - Saint-Petersburg - Estonia/Latvia - Poland.

- Afghanistan - Tajikistan - Bishkek(Kyrgyzstan) - Almaty (Kazakhstan) Aktyubinsk (Kazakhstan) - Uralsk (Kazakhstan) - Saratov (Russia) Samara (Russia) - Saint-Petersburg - Scandinavia.

- Afghanistan - Tajikistan - Bishkek (Kyrgyzstan) - Pavlodar (Kazakhstan) - Moscow - Kaliningrad - EU.

- Central Asia - Russia - Ukraine - Moldova - Romania - Hungary Western Europe.

- Vietnam/China - Bishkek (Kyrgyzstan) - Almaty (Kazakhstan) - Saratov (Russia) - Moscow - Kaliningrad - Poland - Germany.

It is assumed that Russian smugglers and traffickers have close contacts with like-minded actors in countries of origin and transit so that clients are handed over to them from the previous transit stage. Smugglers' networks are flexible and transit routes change frequently in response to the control situation in certain border regions. In 2006, Russian border guards detected a group supposedly specialised in the smuggling of people to the EU through Finland. A special operation was conducted in cooperation with the Russian Federal Security Service and the Finnish Border Guards with the aim of identifying witnesses and prosecuting the organisers (interview with Deputy Head of the Russian Federal Border Service Troufanov, 27 May 2006). Meanwhile, experts from Poland argue that citizens of Afghanistan, India, Pakistan and Iraq (principally Kurds) transit through the Southern Caucasian countries (mainly Azerbaijan) and then through Russia, while migrants from Afghanistan, China, Vietnam and Bangladesh enter Russia 
mainly via the Central Asian states (Jaroszewicz \& Szerepka 2007: 52). In 2008, it was suggested that the route to Southern European countries ran via Ukraine, Moldova and Romania, with smugglers relying on Moldavian networks in Greece, Italy, Spain and Portugal (interview with Deputy Director of the Federal Migration Service Tiurkin, 21 February 2008).

Forged travel documents are a common practice when transit migrants move with the help of smugglers. Passports may be forged, or false data may be printed on legal blank passports. In Russia, visas are not usually forged but the data contained therein (especially the expiry date) may be falsified. But in Kyrgyzstan, forged visas are the most common type of violation. In Tajikistan, too, forged visas may be found, but irregular migrants most often use forged Tajik and Kyrgyz passports (IOM 2006). Chinese, Indian and Sri Lankan migrants reportedly purchase forged passports in Singapore and Hong Kong, where the market for such documents is flourishing. Middle Eastern migrants often seem to purchase forged documents in Lebanon and Turkey. Until recently, there were no foreign consulates in Afghanistan and Afghans first had to travel to Iran, Pakistan and Saudi Arabia in order to obtain visas to Tajikistan and Russia (IOM 2002: 39). Finally, in Moscow there is a growing market for forged passports with legal Russian, Belarusian and Ukrainian visas.

\section{Transit migrants' profiles}

In the early 199os, transit migrants in Russia were mainly young males, two thirds of them under 30 years old, and originating from metropolitan centres or large cities (IOM 1995). Migrants from Afghanistan and CIS states were primarily married, most often with children, while migrants from Africa and other countries were usually single. Half of the migrants were Muslims and 30 per cent were Christians. In most cases (73 per cent), migrants arrived in Russia directly from their countries of origin. The majority of transit migrants from non-former Soviet states were well educated: 30 per cent were students, every third respondent had a university degree and 6 per cent had a college diploma. Approximately half of all migrants could speak a European language other than Russian. In 2002, another survey of irregular migrants was conducted in Saint Petersburg, Saratov, Stavropol, Ulan-Ude, Khabarovsk and Vladivostok (IOM 2004:86-160). It involved 210 irregular migrants who declared that they were 'transit migrants'. According to this survey, 12 per cent of them had finished higher education, 32 per cent had graduated from professional colleges and 20 per cent had secondary education. Over 40 per cent stated that they had no, or poor, Russian language proficiency. Hence, the educational level of this cohort was lower than that for 1994. 
The comparison of the two surveys conducted in 1994 and 2001 also reveals differences in the employment experiences in countries of origin. In 1994, migrants had a stable livelihood: half of the respondents had a full-time or contract job, or their own business. Among those who were employed, 20 per cent worked in the science and education sector, 27 per cent were office workers, engineers, technicians, or medical workers and only 7 per cent were unemployed before emigration. Accordingly, three quarters of the respondents stated they had 'normal' or 'high' living standards. Chinese and Vietnamese migrants, however, were an exception and one quarter described their living standard as 'very poor' (IOM 1994). In 2001, 31 per cent of respondents said that they had a full-time job in their own country, 12 per cent said that they had their own business, and 22 per cent were students. However, 55 per cent said that their income was insufficient and living conditions were poor, considerably more than in 1994; 56 per cent were residents in big cities (Centre for Political Information 2002). This demonstrates that by 2001 more migrants from poorer backgrounds had arrived than in 1994.

The majority of migrants have long-standing contacts with Russia. The IOM (1995) survey found that two thirds of the informants spoke some Russian, 42 per cent of the migrants with university degrees graduated from Soviet/Russian universities and schools of higher education. Around 10 per cent of the migrants were Vietnamese unwilling to leave Russia after the expiry of their work contract. Of the Afghans, many were in Russia for training purposes. Every third migrant from Afghanistan and every fourth migrant from a Middle Eastern country had family members who had previous experience of living in Russia. In contrast, three quarters of the migrants from African countries reported that they had no relatives or friends in Russia. This implies that they could rely less on ethnic networks.

Over 6o per cent of Afghans and 75 per cent of Africans complained about their poor situation in Russia. They lived mainly in hostels and homes rented by the UN; for instance, one room for a family or several persons. Three quarters of those interviewed found the situation in Russia much worse than they expected. Forty per cent of migrants from Middle East countries received money from their families in the homeland and about 20 per cent from their relatives living in other countries. Among migrants from African states, who were generally poorer, over 8 o per cent did not get any assistance from their families. Only two groups seemed to have benefited from migration to Russia: the Chinese and Vietnamese respondents. They came in search of jobs and mainly became petty traders. Their level of employment in Russia is higher than in their homelands, $5^{8}$ per cent against 
43 per cent; 60 per cent were satisfied with their standard of living in Russia, hence their migration project could be considered a success. Nevertheless, one third of all Chinese and Vietnamese respondents preferred to leave for Europe or the USA (Gelbras 2002).

So far, the overwhelming majority of all migrants have entered Russia through regular channels. Since 1992, migrants from the CIS - except the Baltic States, Georgia and Turkmenistan - have been able enter under visa-free agreements. Migrants from countries that were not part of the USSR require a visa in order to enter Russia. In 1994, it was found that only 14 per cent of respondents lacked a visa; by 2002, this had diminished to 8 per cent.

\section{Chinese migrants in Moscow and their smuggling networks}

The Chinese ethnic community in Moscow is growing rapidly both in size and economic relevance. Experts estimate its size to be 40,000-50,000 individuals (Gelbras 2001, 2002). Gelbras' survey of the Chinese ethnic community in Moscow has proved that it is a strong and active economic and social organism which is developing 'in parallel', that is, not integrating with local society and industry. It has developed a separate financial system, various companies, independent media, hotels, hostels, shops and restaurants. The Chinese community in Moscow is closely connected with Chinese communities in other parts of Russia; there they are rapidly developing in similar ways to the patterns observed in Moscow.

As early as in the mid-1990s, western media suspected that Chinese migrants were using Moscow as a transit stage on their way to Europe and America (see Gelbras 2001). Newspapers in China published advertisements of tourist agencies specialised in this kind of business. It was reported that the price for smuggling a Chinese migrant to the USA via Moscow, including acquiring subsequent legal status in the USA, was USD 40,000-50,000 (Sumay \& Rumyantsev 1999: 114). The cost of the Moscow part of the chain was USD 6,000-10,00o. According to Sumay and Rumyantsev (1999), the group of persons who wish to be smuggled, the so-called 'snake', is organised and headed by the 'snake head' (sha-tow). Chinese migrants on the move were associated with flocks of duck (yatzy) that cross state borders without permission, just like irregular migrants.

Gelbras' survey (2002, also see the annex to this chapter, table 6.6) of Chinese migrants in Moscow has shown the emergence of Chinese firms dealing with invitations and visa support for Chinese nationals who would like to immigrate to Russia or to other countries using Russia as a transit stage. The community's institutions seem to provide their compatriots 
with the full scope of services for illegal or semi-legal transit migration to a desired country. Chinese newspapers issued in Moscow published advertisements of agencies that openly offer services to smuggle Chinese migrants to Schengen countries, the USA, Canada, Australia, South Africa and Latin America (Gelbras 2002: 27). Thus, the Chinese appear to be an exception from the 'norm', according to which transit migrants usually resort to the help of Russian smugglers. Gelbras' survey also illustrates the popularity of the 'study channel' as a transit stage: 41.5 per cent of the interviewees openly admitted that they intend to go to another country after graduating from a Russian university (see annex to this chapter, table 6.5). Others who enter with a study visa do not even attend lectures and instead use their stay in Russia to prepare their move to another country of their choice.

\section{Timing and destination of on-migration}

Earlier surveys show that Western countries are the general destination of migrants in transit (IOM 1995). Refugees from the former Soviet states were mainly eager to reach the USA and Canada. Africans, Asians, Middle Easterners and Kurds prefer Western Europe; indeed, they indicate 'any other country except Russia' as their aim. Among countries of destination, migrants most often mentioned the USA, Denmark, Sweden, Canada, France, Great Britain and Germany. This can be explained by the network effect of immigration communities. A quarter of those who aimed to move west had family members already living there, so their choice of destination was inspired by the wish to reunite with their family. The geography of family connections is very wide - the USA, Germany, the Netherlands, Belgium, Denmark, France, Scandinavia and Canada were the most commonly reported. In general, migrants had twice as many or more relatives and friends in Western Europe than in the United States and Canada.

However, in spite of these ties, the overwhelming majority of those migrants who wished to move on to the West had a very poor understanding of immigration rules and possibilities in destination countries. The majority made no precise statement regarding their intentions and terms of departure. Of the total, 6o per cent said that they had made no practical efforts to arrange their departure from Russia but were just waiting for a 'better chance'; indeed, 35 per cent reported that they lacked the financial means for moving onward. In contrast, 18 per cent asked their relatives for an invitation and 15 per cent applied to the UNHCR Office for assistance in departing. About half of the respondents who wished to move on believed that they had sufficient documents. Several, however, admitted that they had paid a very high price for these; thus, it is plausible to assume that they were not obtained legally. 
The 1994 survey also revealed an interesting correlation between the duration of the stay in Russia and the migrants' intentions (see annex to this chapter, figure 6.1). It seems the longer the migrants stayed in Russia, the less likely it became that they moved on; instead they adapted to life in Russia, engaged in businesses and obtained legal status or got used to their irregular position (IOM 1995).

The 2001 survey has detected that at least 38 per cent of transit migrants in Moscow were in contact with professional smugglers (Centre for Political Information 2002). The real percentage was likely to be even higher because not all respondents were prepared to admit such contacts, as these services are illegal. Generally, of the total number of migrants who aimed to leave for another country, 72 per cent said that they would agree to move 'illegally' in case they did not have legal alternatives. However, the majority preferred to live in Europe or the USA legally (ibid.). Their hopes to legalise their status in destination countries were related to the presence of family members there, assistance of international charity organisations, asylum opportunities, regularisation programmes and general respect for human rights and dignity in liberal democratic societies.

\subsection{Interstate cooperation in counteracting irregular migration, human smuggling and trafficking}

Generally, in the post-Soviet, CIS and Central Asian region, international migration is an area of active interstate cooperation, both on a bilateral and multilateral basis. Whilst no interstate policy specifically addresses transit migration, various policies are concerned with irregular migration, smuggling and trafficking. The Declaration on Concerted Migration Policy adopted by the CIS member states in 2007 summarises the number of previous agreements on migration. Irregular migration, human smuggling and trafficking in human beings are believed to be widespread in the region and the governments of all the states of the Eurasian post-Soviet space are aware of the problem. They commonly agree with the need for collaboration in order to counteract these phenomena. In the past few years these issues have found their way onto the agendas of regional organisations, namely the CIS and the Eurasian Economic Community (EURASEC). ${ }^{2}$ The citizens of most post-Soviet states enjoy the privilege of visa-free cross-border movements

2 EURASEC was founded in 2000. Presently, its member states are Belarus, Kazakhstan, Kyrgyzstan, the Russian Federation, Tajikistan and Uzbekistan. 
inside CIS territory. Therefore, efforts of CIS member-states to counteract irregular migration mainly target migrants from third countries; this includes those who are in transit in the CIS area making their way to the West. Efforts to prevent human trafficking are concerned rather with the citizens of the former Soviet states who are often thought to be victims of human traffickers, both for sexual and labour exploitation.

In counteracting irregular migration, governments of the region act within the framework of the 1998 CIS 'Agreement on Cooperation in Fighting Irregular Migration' and the CIS 'Concept of Cooperation in Counteracting Irregular Migration' adopted in 2004. The major instruments to suppress irregular migration are detection and restraining channels of irregular migration, cooperation in the field of information exchange, elaboration of a common database on migrants, harmonisation of migration legislation, prosecution of human smugglers and other types of people aiding irregular migration, and improvement of border control and identification document technologies. On the other hand, the EURASEC agreements in this field focus mainly on the development and encouragement of regular forms of labour migration as an alternative to irregular migration.

All countries of the post-Soviet space, with the exception of Turkmenistan, have adopted the 2000 UN Convention against Transnational Organized Crime and its supplementary Protocols Against Trafficking in Human Beings and Smuggling of Migrants. Following this, efforts were made to bring national laws in line with the provisions of the convention. This included introducing relevant articles into the criminal codes of these countries; qualifying the traffic in human beings as a separate crime, determined in accordance with the definition of the UN Protocol; developing mechanisms for the implementation of measures aimed against human traffickers; and conducting information campaigns and rendering aid to victims. For instance, in 2003, the Russian Criminal Code was amended with articles on organisers of irregular migration, human traffickers and modern slavery.

The position of Russia as a country transited by migrants discourages the government from signing bilateral readmission agreements with its western neighbours. This is because readmission agreements with the transit migrants' destination countries require similar agreements with the origin countries; otherwise a country of transit risks becoming a reservoir for irregular migrants. Therefore, the implementation of the Agreement on Readmission signed between Russia and the EU in May 2006 and put in force on 1 June 2007 suffers from the absence of bilateral readmission agreements between Russia and the transit migrants' countries of origin. 
So far, during an initial period of three years from signing this EU-Russia agreement, it is limited to citizens of the Russian Federation and nationals from the countries that have signed readmission agreements with Russia - to date only Lithuania (2006) and Ukraine (2008). Other agreements are under consideration.

\subsection{Conclusion}

This contribution has revealed the ambivalent position of Russia with respect to transit migration. On the one hand, it is a geographic region with social structures that facilitate transit migration. On the other hand, the evidence presented here demonstrates that Russia is also a barrier for migrants who are on their way west. Transit migration in this region tends to be extensive in duration, and is closely related to irregular migration and smuggling. When choosing their transit route via Russia, migrants from Asian and African countries do not seem to anticipate the difficulties of staying in Russia and trying to pass the EU border. Relatively simple entry regimes at Russia's southern and eastern borders contrast with wellorganised and sophisticated border controls on the western side. This results in a phenomenon which could be called 'failed transit migration', that is, migrants who, because of tight control at both sides of the Russian-European border, get stuck in the supposed country of transit.

Russian authorities have become concerned that Russia is becoming a reservoir for irregular migrants (IOM 2004: 47). These concerns are based on two grounds: first, migrants are not eager to legalise and integrate but maintain the view that their stay is only strategic, temporary and forced. Second, irregular migrants, because they lack proper status, subsequently engage in further unlawful activities, notably irregular employment. Irregular transit migration through Russia challenges various security considerations of the Russian state. The State is confronted with large numbers of migrants who get 'stuck' there in an irregular situation and who maintain their aim to reach Western countries, though many will not succeed. Migrants face a hostile welcome, poor living standards, criminal or semi-criminal environments, an infringement of their dignity and uncertain futures. This situation calls for solutions to be sought.

It seems likely that transit migration through Russia westward will continue. So, the government will continue to improve its border and migration management in order to integrate it in a 'civilised' framework and reduce its criminal segments. The Federal Border Service is likely to improve entry and 
border controls, in particular on the extensive eastern borders, in order to address irregular (transit) migration. In addition to this, Russia already leads intergovernmental initiatives regarding migration management within the framework of the Eurasian migration system, and thus demonstrates its interest in regulating migration and combating irregular international movements of populations. However, if migrants are already within Russian territory, they need to be treated with respect and according to human rights standards. The transit migrant issue is not only a challenge for the transit countries. The origin countries are also held responsible for their own citizens. As a consequence, they are included in the development of cooperation with host countries, for example, with respect to readmission agreements. Moreover, to be effective, measures to manage and protect transit migrants need to be integrated into existing human rights, civil society and institution-building activities in the countries of destination, transit and origin. Acute problems relating to the situation of migrants in transit necessitates the issue being regarded as an integral part of the general migration policy debate.

Transit migration, as demonstrated in this chapter, cannot be seen as separate from other forms of migration, such as student or temporary migration, as these are closely interrelated. Despite the scale of this phenomenon it is not recognised in national and international legislation. Notably the occurrence of irregular transit migration with all its negative consequences seems to result from the absence of clear and transparent migration policies.

\section{Annex}

Table 6.1 Numbers of transit migrants (persons)

\begin{tabular}{lccc}
\hline Years & Entered Russia & Departed from Russia & Net transit \\
\hline 2006 & 574,229 & 380,934 & 193,295 \\
2007 & 463,503 & 308,552 & 154,951 \\
2008 & 382,761 & 214,060 & 168,701 \\
2009 & 282,368 & 152,347 & 113,002 \\
\hline
\end{tabular}

Note: Data from the Border Service of the Russian Federation (number of entries/departures, by purpose declared when passing the border)

Source: National Statistics Committee of the Russian Federation (ROSSTAT) $(2008,2010)$ 


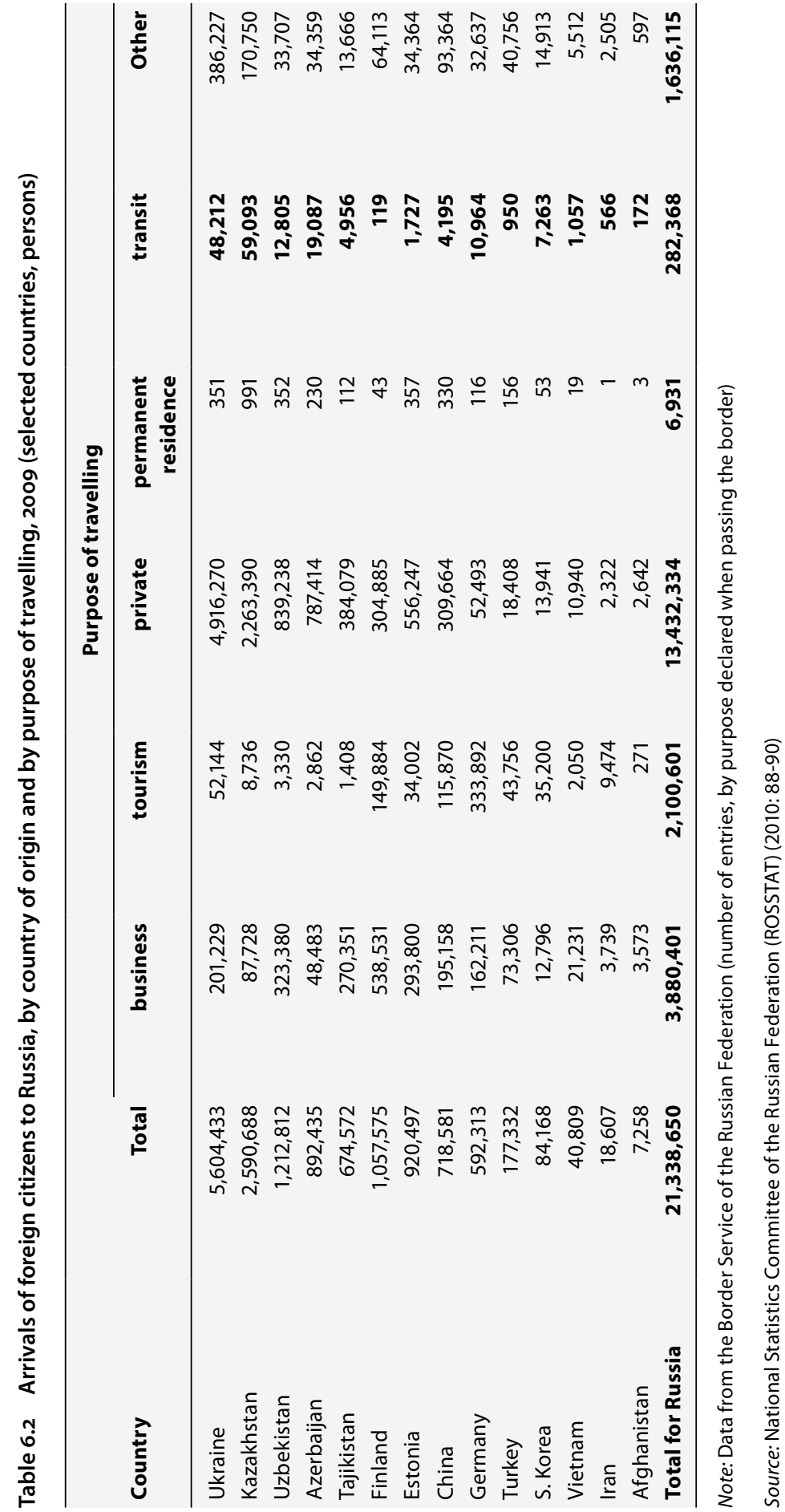




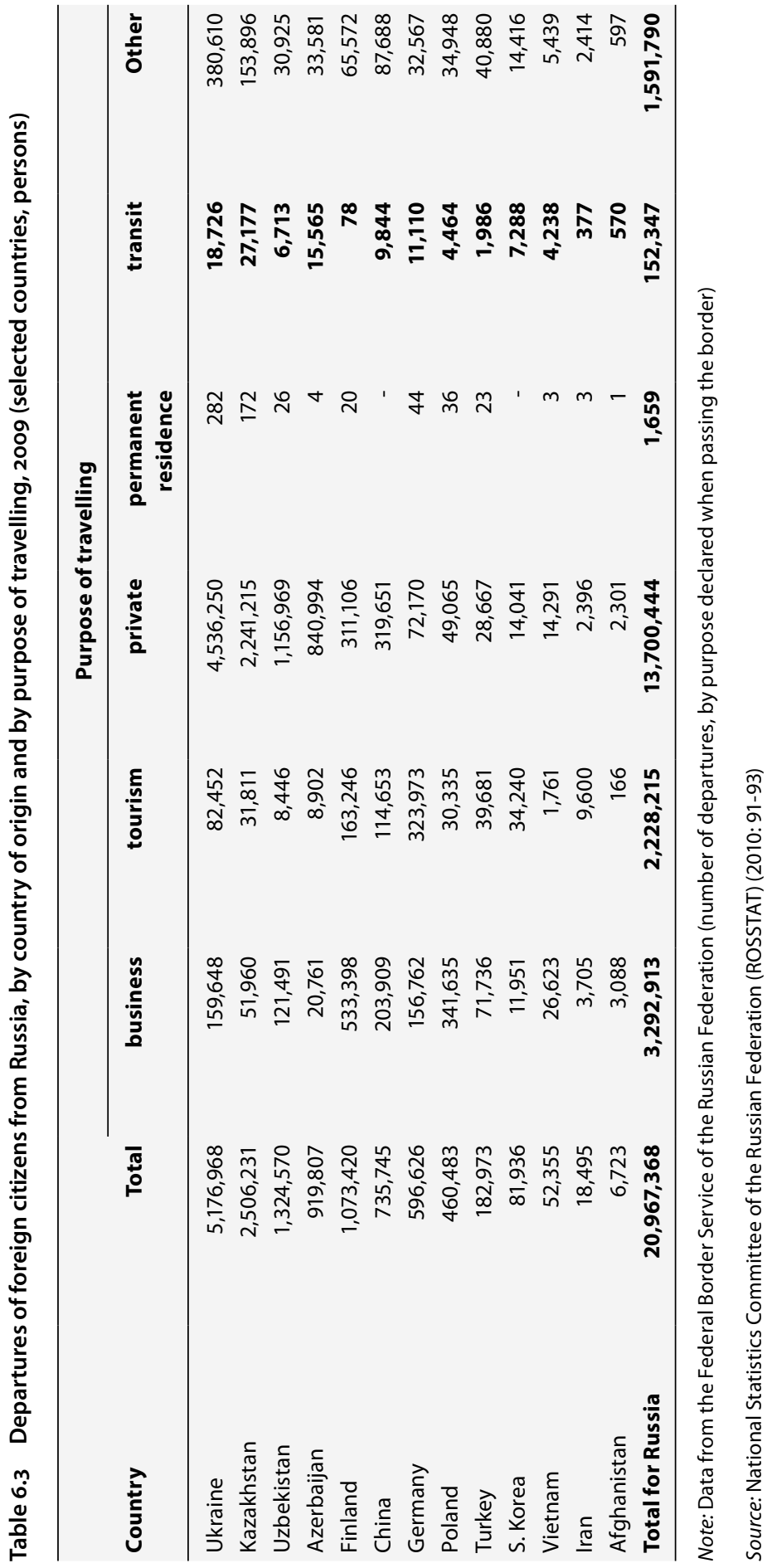


Table 6.4 Immigration to Russia from other countries by reasons, 2009 compared to 2006

\begin{tabular}{|c|c|c|c|c|}
\hline \multirow[t]{2}{*}{ Reasons to depart for Russia } & \multicolumn{2}{|c|}{$\begin{array}{c}\text { From CIS and Baltic } \\
\text { countries }\end{array}$} & \multicolumn{2}{|c|}{ From other countries } \\
\hline & 2006 & 2009 & 2006 & 2009 \\
\hline Employment-related & 12,018 & 7,562 & 203 & 586 \\
\hline Repatriation & 10,087 & 2,484 & 1,541 & 141 \\
\hline Ethnic conflicts & 4,646 & 404 & 17 & 9 \\
\hline Highly criminal atmosphere & 402 & 37 & 4 & 1 \\
\hline Ecological troubles & 434 & 60 & 9 & 1 \\
\hline Inadequate climate conditions & 450 & 99 & 22 & - \\
\hline Personal, family reasons & 113,003 & 27,163 & 3,021 & 975 \\
\hline Other reasons & 12,261 & 2,798 & 548 & 77 \\
\hline Reason not indicated & 3,932 & 11,739 & 1,089 & 644 \\
\hline Total immigration & 157,233 & 52,346 & 6,454 & 2,434 \\
\hline
\end{tabular}

Note: Migrants 14 years and older

Source: National Statistics Committee of the Russian Federation (ROSSTAT) (2010: 124)

Table 6.5 Why did you choose to immigrate to Russia (percentage)?

\begin{tabular}{lccccc}
\hline Motives & $\begin{array}{c}\text { Former } \\
\text { Soviet states }\end{array}$ & Africa & $\begin{array}{c}\text { Afghani- } \\
\text { stan }\end{array}$ & $\begin{array}{c}\text { South- } \\
\text { East Asia }\end{array}$ & $\begin{array}{c}\text { Middle } \\
\text { East }\end{array}$ \\
\hline Employment & 27 & 6 & 6 & 44 & 5 \\
Study & 10 & 40 & 14 & 30 & 32 \\
Family reunification & 27 & 1 & 6 & - & 11 \\
It is easier to get visa & - & 16 & 27 & 5 & 23 \\
It is easier to get & - & 24 & 8 & 9 & 14 \\
refugee status & & - & 18 & 2 & 2 \\
I knew Russia before & 27 & & & & \\
\hline
\end{tabular}

Source: IOM (1995: 25) 
Table 6.6 The plans of Chinese students after graduating from Moscow universities (percentage)

\begin{tabular}{ll}
\hline To get Russian citizenship and stay in Russia & 2.4 \\
To get permanent residence permit in Russia & 7.3 \\
To leave for another country & 41.5 \\
To return to China & 48.8 \\
TOTAL & 100.0 \\
\hline
\end{tabular}

Source: Gelbras (2002)

Figure 6.1 Duration of stay in Russia and migration intentions

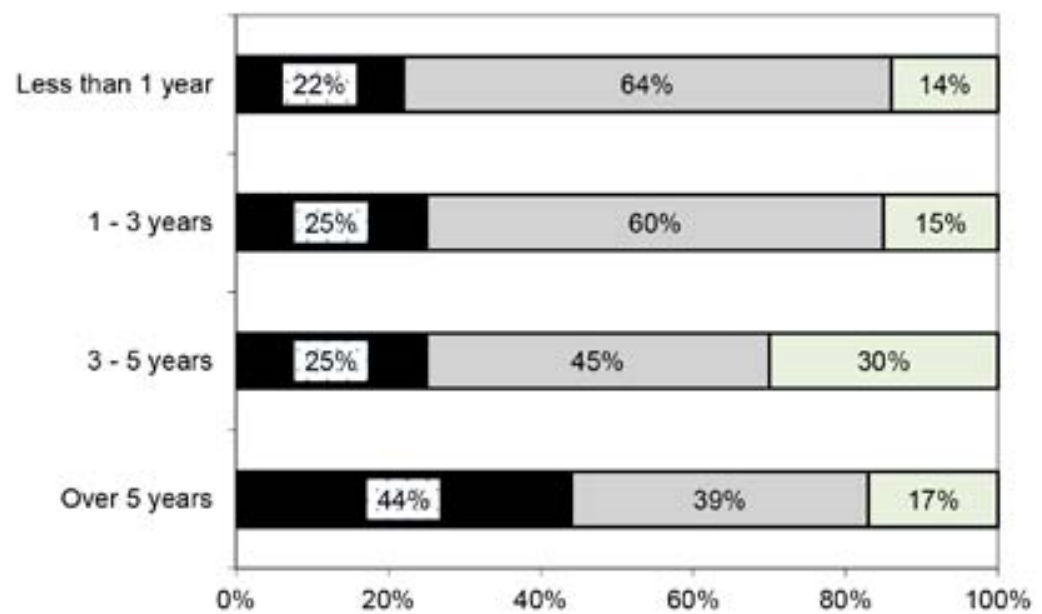

Legend: black: 'I am planning to leave Russia'; grey: 'I am not planning to leave Russia'; white: 'I have not decided yet'.

Source: Transitnaia migratsia v Rossiiskoi Federatsii [Transit Migration in the Russian Federation] (1994), Migration Information Programme (IOM), Budapest

\section{List of interviews conducted by the author for the purposes of this study}

Deputy-Director of the Federal Migration Service Vyacheslav Postavnin, 18 December 2007. Deputy-Director of the Federal Migration Service Mikhail Tiurkin, 21 December 2008. Deputy Head of the Russian Federal Border Service Vladimir Troufanov, 27 May 2006. 


\section{References}

Centre for Political Information (2002), Nelegalnaya Transitnaya Migratsiya v Rossii [Irregular Transit Migration in Russia]. Moscow: Centre for Political Information.

Gelbras, V. (2001), Kitayskaya Realnost Rossii [The Chinese Reality of Russia]. Moscow: Muravey.

Gelbras, V. (2002), 'Kitaiskaya migratsia i kitaiskiye zemlyachestva v Rossii' [Chinese migration and Chinese ethnic communities in Russia], in V. Iontev (ed.) World in the Mirror of International Migration. Scientific Series 'International Migration: Russia and the Contemporary World, Vol. 10. Moscow: MAX Press (in Russian).

Gromovs, J. (2007), 'Overview of migration trends in the countries: EU member states of the Soderkoping process for the period of 2004-2006', in European Commission, Migration Trends 2004-2006: Soderkoping Process Countries. Brussels: European Commission, 34-62.

ICMPD (2006), Overview of the CIS Migration Systems. Vienna: International Centre for Migration Policy Development.

Interpol (2010), People Smuggling, www.interpol.int/Public/THB/PeopleSmuggling/Default.asp. IOM (1995), Transit Migration in the Russian Federation. Budapest: IOM.

IOM (2002), Migration Trends in Eastern Europe and Central Asia. 2001-2002 Review. Geneva: IOM. IOM (2003), World Migration. Geneva: IOM.

IOM (2004), Problema Nezakonnoy Migratsii v Rossii: Realii i Poisk Resheniy [Problem of Irregular Migration in Russia: Reality and Search for Solutions (results of the sociological survey)]. Moscow: Gendalf.

IOM (2006), Smuggling of Migrants to/from/through Central Asia. Background Research. Vienna: IOM Office for Europe and Central Asia.

Ivakhnyuk, I. (2004), 'Analysis of the economic, social, demographic and political basis of transit migration in Russia', in Migrants in the Transit Countries: Sharing Responsibilities in Management and Protection. Proceedings of the Council of Europe Regional Conference on Migration, Istanbul, 30 September to 1 October 2004, Council of Europe, Strasbourg, 18-38.

Ivakhnyuk, I. (2005a), 'Russia-EU: Interactions within the reshaping European migration space', in K. Slany (ed.), International Migration:A Multidimensional Analysis. Cracow: AGH University of Science and Technology Press, 217-250.

Ivakhnyuk, I. (2005b), 'Illegal migration: Russia', in A. Aldis \& G. Herd (eds), Soft Security Threats and European Security. London and New York: Routledge, 35-53.

Ivakhnyuk, I. (2007), 'Eurasian migration system: Theoretical and political approaches', in V. Iontsev (ed.), Migration and Development. Scientific Series 'International Migration of Population: Russia and Contemporary World', Vol. 2o. Moscow: SP Mysl, BL Print, 81-99.

Jaroszewicz, M. \& L. Szerepka (2007), Migration Challenges in the European Union's Eastern Neighbourhood. Warsaw: Centre for Eastern Studies.

Kozina, I., M. Karelina \& T. Metalina (2005), 'Trudoviye practiki inostrannykh rabochih v Rossii' ['Labour practices of foreign workers in Russia'], Sotsiologicheskiye issledovaniya [Sociological Surveys ] 2, Moscow. Also available at:www.demoscope.ru/weekly/20o6/o235/analito11.php, retrieved 25 April 2011.

Krasinets, E., E. Kubishin \& E. Tiuriukanova (2000), Nelegalnaya Migratsiya v Rossii [Illegal migration to Russia]. Moscow: Academia.

Krasinets, E. (2006), 'Nelegalnaya migratsiya i migratsionnaya politika v Rossii' [Irregular migration and migration policy in Russia], in Y. Latov, \& O. Vykhovanets (eds), Economics of Crimes and Punishments. Scientific Journal 'Irregular Migration in the Contemporary Russia', Vol. 8. Moscow (in Russian), 40-50. 
Massey, D. S., Joaquin Arango, Graeme Hugo, Ali Kouaouci, Adela Pellegrino \& J. Edward Taylor (1993), 'Theories of International Migration: A Review and Appraisal', Population and Development Review 19 (3): 431-466.

Mukomel, V. (2005), Migratsionnaya Politika v Rossii: Postsovetskiye Konteksty [Migration Policies of Russia: Post-Soviet Contexts]. Moscow: Institute for Sociology of the Russian Academy of Sciences, Dipol.

Olimov K.O. (2009), 'Postkonfloktniye protsessi i migratsionniye problemi' [Post-conflict processes and migration problems], in Migratsionniy Most Mejdu Tcentralnoy Aziei i Rossiei: Modelirovaniye i Effectivnoye Upravleniye Migratsionnymi Potokami [Migration Bridge between Central Asia and Russia: Modelling and Effective Management of Migration Flows]. Proceedings of the International Symposium. Moscow-Khoujand, 22-26 September, 188-191.

Pribytkova, I. (2007), 'Regular and irregular migration in Ukraine, Belarus and Moldova, 20042006', in European Commission (ed.), Migration Trends 2004-20o6 Soderkoping Process Countries. Brussels: European Commission, 5-33.

Radaev, V. (1999), 'Tenevaya ekonomika Rossii: izmeneniye konturov' [Shadow Economy of Russia: Reshaping the Contours], Pro et Contra, Winter 1999: 5-24.

ROSSTAT (2008), 'Chislennost i migratsiya naseleniya $v$ Rossii $v 2007$ godu' [Population and Migration in the Russian Federation in 2007]. Statistics Bulletin. Moscow: National Statistics Committee of the Russian Federation.

ROSSTAT (2010), 'Chislennost imigratsiya naseleniya v Rossiiv 2009 godu' [Population and Migration in the Russian Federation in 2009]. Statistics Bulletin. Moscow: National Statistics Committee of the Russian Federation (in Russian).

Sumay, L. \& E. Rumyantsev (1999), Kitay Kak ya Ego Znayu [China as IKnow It]. Moscow: UPAPS. Tiuriukanova, E. (2004), 'Migranti na neformalnom rynke truda v Moskve' [Migrants at the informal labour market in Moscow], in IOM Moscow (ed.), Problem of Irregular Migration in Russia: Reality and Search for Solutions (Results of the Sociological Survey). Moscow: IOM Office in the Russian Federation, 161-195.

Vitkovskaya, G. (2002), 'Nezakonnaya migratsiya v Rossii: situatsiya i politika protivodeystviya' [Irregular migration in Russia: Situation and policy of counteraction], in V. Iontsev (ed.), Illegal Immigration. Scientific series 'International Migration: Russia and the Contemporary World', Volume 9, Moscow MAX Press (in Russian), 11-34. 



\title{
$7 \quad$ Hungary and the System of European Transit Migration
}

\author{
Irina Molodikova
}

\subsection{Introduction}

The role of EU frontier countries has usually been that of a buffer against illegal migrants and asylum seekers travelling West. For example, Hungary has functioned as a buffer between East and West for more than half a century. Already during the Soviet era, the Hungarian western border was the frontier of the Socialist system. After its collapse and the opening of the western border, Hungary constituted a contentious barrier against illegal migrants and asylum seekers to the West. After the enlargement of the EU in 2004, the Hungarian eastern border became the EU frontier and in December 2007 Hungary was brought into the Schengen zone, hence controls of the external borders were raised to EU standards whilst controls on internal borders with other Schengen states were abandoned.

Hungary's role as a frontier is also related to its reputation as a transit country for the last twenty years (IOM 1994, 1995, 2000; Tóth 2005; HHC 1999, 2003; Ju hasz 2003). The number of migrants and applicants for asylum in Hungary is small in comparison with other EU borderland countries. It is currently participating in the realisation of the EU Eastern European Neighbourhood Initiative (ENI). Nevertheless, Hungary has a special position in terms of its relation with the wider neighbourhood, in spite of the adoption of the common EU migration regulations. Indeed, Hungary is a good example of dualism and ambiguity in the implementation of EU migration policy. It is manoeuvring 'in between' the obligations of the Acquis Communautaire of the $\mathrm{EU}$ and obligations to compatriots living in neighbouring non-EU countries.

Since Hungary fully implemented the Schengen agreement it has performed its frontier role through a variety of border relationships with its neighbourhood. Hungary had until 2013 at least three different types of external border relations: the first is with EU but non-Schengen member states (notably Romania); the second is with non-EU but candidate member states (Croatia); and the third is with non-EU third countries (notably Ukraine and Serbia). In addition, Hungary implements a special system of liberal border crossing zones for the migration of ethnic Hungarians from 
Ukraine and Serbia, creating a 'window of opportunities'. This 'window' functions as a specific asymmetric 'filter' that allows relatively free movement for ethnic Hungarians and also other citizens of non-EU countries, who live in a frontier zone of 55 kilometres within the border. Both Serbia and Ukraine are well known in Western Europe for irregular and transit migration, in spite of various political and financial efforts made by the EU to establish a protected border against irregular migrants. Furthermore, in 2010 the EU lifted the visa requirement for citizens of the Western Balkans ${ }^{1}$ and allowed their citizens to freely pass the Hungarian border. This EU decision provoked changes in the flows of asylum seekers into Europe: on one hand, the number of applications for asylum in Hungary halved; on the the other hand, this reduction contrasted with a rise in the level of asylum applications in Germany and Sweden. It is suggested that refugees are more likely to enter and pass through Hungary undetected in order apply for asylum in a preferred country. This further substantiates Hungary's reputation as transit state.

To understand the nature of transit migration in Hungary we must analyse the processes and types of migration flows over recent years in the context of the behaviour of different migrant groups and in the changing realities of the EU borderlands. It is essential to ask if the term 'transit migration' has the same meaning now as in previous realities, or whether it is a new political construction. What are the most important factors that facilitate the transit of migrants through the country? For which groups of migrants does the country appear to be a country of transit? What is the difference between the groups of migrants who want to remain in Hungary and those who try to pass through Hungary into Western Europe? Does the recent readmission agreement create new realities for transit migration between the East and West?

In order to answer these questions, we looked at the migration processes around Hungary using a broad approach. We assumed that the 'non departure' regime of the Cold War has been replaced by the 'non-arrival regime' [of the] New World order' (Castles 2002: 9). This meant that as well as examining the peculiarities of the migration context in Hungary, we also examined the opportunities and willingness of neighbouring third countries to support the EU policy on fighting illegal migrants and preventing unwanted migrants. Additionally, highlighted here are the adaptation strategies of persons who asked for asylum in Hungary after they successfully passed the EU (Hungarian) border. 


\subsection{Theoretical and methodological approaches to research}

There are different approaches in the research on transit migration that look at migrants trying to reach particular destination countries such as those in the European Union or the United States; in particular, unauthorised migration raises most concerns. Migrants use the geographical location of countries that neighbour their destination to get easier access to, for instance, the EU or USA (Haas 2005, Düvell 2007, Kimball 2007).

In the case of Hungary, transit migration has several dimensions: the first is the process of passing a country; the second is being stranded in a transit space and unable to move on; and the third is the pushing of migrants by officials to move through Hungary to another country (HHC 2003, 2010; HRW 2010; Molodikova 2009). These situations often deteriorate on account of the illegality of entrance, as is the case for about 90 per cent of asylum seekers in Hungary (OIN 2011). In addition, there are many other factors which influence the transit nature of territory and that can create favourable conditions for transit migrants. Often, the economic prosperity of local populations bears a strong relation to the border-zone activities, as the opportunity for using these activities for economic income is used by both ordinary citizens and local officials (Donnan \& Wilson 2001).

In the context of the European Union, the discussions of the factors of transit should evaluate the network of relations that composed the economic, cultural and political ties of the EU with third countries that hold the transit flows (Fawcett 1989; Gurak \& Caces 1992; Massey et al. 1998). The existing networks of persons or groups of persons (diasporas) in combination with different types of visa regimes establish social infrastructures between sending and receiving countries and create sustainable interactions (Gurak \& Caces 1992). In the context of network theory (Massey et al. 1993) the existence of networks and diasporas simultaneously increases the potential social capital (access to resources, information and contacts) that supports the integration opportunities of migrants in a particular country.

Based on this proposition one can argue that a relatively homogeneous Hungarian society can attract only Hungarians from neighbouring countries. Other migrants (especially asylum seekers) in the absence of a friendly and helpful milieu, friends or a diaspora, in combination with a difficult, indigenous language, have few opportunities for rooting there. This is the reason why people who are not from neighbouring countries, and without a support network, do not consider Hungary a viable destination country. 


\section{Research methodology}

In order to research the function and history of Hungary as a transit country and the changes in Hungarian migration policy as well as in the directions and types of migration flows, different methods of analysis were used. So far, there is neither an agreed definition as to what transit migration is, nor any reliable statistics on the transit flow. Therefore, scholars who investigate this phenomenon use data from different surveys, interviews and available statistics on irregular migration and border crossing (Kimball 2007; Düvell 2007; Haas 2005; ICMPD 2007, 2010; IOM 2000).

For this chapter, first, desk research conducted on migration from third (non-EU) countries to Hungary was used to assess the issue of Hungary's attractiveness as a destination country for different types of migrants (labour, education, ethnic migration and asylum seekers). For this purpose, various reports of international organisations (HHC 2010; HRW 2010) were consulted. In addition, different statistics from the Office on Immigration and Nationals (OIN) of Hungary, the Statistic Committee, the Demographic Research Institute of Hungary and other relevant sources were used.Second, a field trip was conducted in July 2010 involving four passages of borders in the Ukrainian borderland with Poland, Hungary, Romania and Moldova. In the course of these research trips, interviews were conducted with border guards (3), two smugglers and with the local population (5). Additional meetings were held with (a) the Ukrainian head of migration services in Uzhgorod and (b) with regional experts. Third, in order to study officials' perceptions of migration flows, the author analysed 12 in-depth, qualitative and semi-structured interviews with Hungarian civil servants from various organisations. These interviews were conducted in 2005, 2007 and $2011 .{ }^{2}$ They involved questions about transit migration and the externalisation of EU migration policy. Fourth, a small-scale longitudinal data survey was conducted involving 30 asylum seekers in Hungary with different forms of protection (refugees, subsidiary protected persons and persons authorised to stay). They were interviewed twice, first at the end of 2007/beginning of 2008 (at the time of Schengen inclusion) and second three years later in mid-2010. This enabled the gathering of data on their integration strategies. Questions on the development of their general life plans in Hungary and outside helped the author to investigate their transit intentions.

2 State agencies: Ministry of Justice and Law Enforcement, Ministry of the Interior, OIN, administration of refugee camp. Non-governmental organisations: Helsinki Committee, UNHCR, Menedek and lawyers who are involved in advocacy for asylum seekers. 


\subsection{Main types of legal migration flows in Hungary}

In 2011, the population of Hungary dropped below 10 million people and was counted as 9.9 million; this decrease was due to an ageing population (KHS 2010). The decline was observed in spite of a stable positive migration balance. As of 1 January 2011, the number of migrants was 216,084, up from 184,358 in 2009 (OIN 2011). Nevertheless, the share of the immigrant population in Hungary continues to remain at around 2.2 per cent (table 7.1). The general trend over the past 20 years indicates the prevalence of European migration flows (73.9 per cent of the total), with the EU-27 countries being the main sources of immigrants into Hungary (55.7 per cent in 2010). Typically, Romania is the main sending country, but its share declined from a maximum of 54.7 per cent of all migrants in 2004 to 27.8 per cent in 2011. Similar trends have been observed for migration flows from Serbia, which peaked at 19.4 per cent of the total in 2007 and decreased to a mere 4.7 per cent in 2010. Migration flows from Ukraine peaked at 16.3 per cent in 2004 and then fell to 7.4 per cent in 2011. In contrast, the number of Chinese immigrants increased and in 2011 occupied third position, ahead of Serbian immigrants. This demonstrates that the process of ethnic Hungarian migration typical over the past 20 years is now slowly decreasing in relevance and that migration flows to Hungary are becoming more diverse and international (OIN 2011).

Table 7.1 Immigrants and those staying for more than three months in Hungary, number of persons 2009-2010 (without refugees and others with protected status)

\begin{tabular}{lrrr}
\hline Status of permit/year & $\mathbf{2 0 0 8}$ & $\mathbf{2 0 0 9}$ & $\mathbf{2 0 1 0}$ \\
\hline Immigration permit & 47,205 & 47,205 & 42,659 \\
Permanent resident permit & 28,522 & 23,475 & 20,588 \\
Residence permit & 15,304 & 33,682 & 32,897 \\
EEA Residence Permit & 30,579 & 20,855 & 12,990 \\
Registration certificate & 48,527 & 70,248 & 72,938 \\
Permanent residence card & 6,560 & 8,319 & 14,272 \\
Third countries nationals who are family of the Hungarian & & & \\
citizens & 4,733 & 5,562 & 7,025 \\
Third countries nationals who are family of EEA citizens & 322 & 382 & 432 \\
EC permanent residence permit & 242 & 206 & 398 \\
National settlement permit & 2,568 & 4,063 & 5,504 \\
Temporary resident permit & 6 & 6 & 9 \\
Total & $\mathbf{1 8 4 , 5 6 8}$ & $\mathbf{2 1 4 , 0 0 3}$ & $\mathbf{2 0 9 , 7 1 2}$ \\
\hline
\end{tabular}

Source: Homepage of Office for Immigration and Nationalities www.bevandorlas.hu/statisztikak.php 


\section{Ethnic migration}

Hungary still lacks a comprehensive migration policy; existing policies, however, favour ethnic Hungarians and thus reflect an ethnic migration policy. These target migration from neighbouring third countries to the 'motherland' and are noted with concern by other countries. This policy was reinforced in 2010, when the new ruling Hungarian coalition (FIDESZ and Christian Democratic Party) changed the Hungarian Citizenship Law on May 26th, 2010. ${ }^{3}$ This act allows the preferential naturalisation of non-Hungarian citizens with Hungarian ancestors and accelerated the naturalisation procedure. All holders of ethnic Hungarian certificates (923,000 on 31 July 2010) can potentially apply for citizenship. According to expert opinion, the Hungarian government has already allocated an additional budget for these tasks. The OIN and Ministries (Interior, Public Administration and Justice) will receive an additional 200 civil servants, which will cost $€ 1.4$ million within two budget years (Tóth 2010). The process of obtaining citizenship under the new regulations will take 3-4 months and does not require passing the language test or knowledge of the Hungarian constitution and history. Also in 2011, a special residence permit for close relatives of Hungarian citizens was introduced. But the introduction of this card has created significant problems in Hungary because of the unclear status of these documents for different organisations.

This policy of selective immigration of Hungarian ethnic minorities from the neighbouring countries potentially creates an area of free movement between Schengen and non-Schengen countries for certain categories of the population in the third countries. The implementation of new amendments to the Citizenship Law could thus cause considerable changes in geography and types of migration to and through Hungary. In a short time, all Ukrainian and Serbian border areas may actually be inhabited by citizens of Hungary. Taking into consideration the percentage of mixed families in these countries, one can propose that the 'Hungarisation' will involve big areas of neighbouring countries. This national policy could thus potentially undermine EU policy and geo-strategy concerning the control of external borders. Notably due to high levels of corruption in Ukraine and Romania, soon the number of potential applicants for naturalisation could be several times higher than the figures forecast by the Hungarian government.

Already, ethnic Hungarian political parties in Ukraine aim to attract the voters among co-ethnic populations through the issuing of ethnic cards (guaranteeing the above privileges) and through providing assistance in 
granting free Schengen visas in exchange for support in elections. One informant explains:

Our families got the Hungarian cards and Schengen visas very simply. We just have to go to our Hungarian party meetings and promise to vote for them (from two interviews by the author in March and April 2009).

\section{Labour migration}

Another important flow of immigrants is related to labour migration; this is also closely related to ethnic migration as well as to transit migration. In 2011, 16,06o work permits were issued, mainly to Chinese, Vietnamese and Mongolian labour migrants who are now among the top five nationalities of labour migrants in Hungary (OIN 2011). According to Gördi (2010: 8), however, ethnic migration to Hungary is mainly economic and until 2007 the share of ethnic Hungarians among economic migrants was about 65 per cent. In 2006, before Hungary acceded the Schengen zone, new laws were adopted which came into force in 2007: Act I 'About the entry and residence of persons from EEA countries' and Act II 'About the entry and residence of persons from third countries including families of members of EEA citizens'. From that time, Romanian citizens were entitled to a residence permit called a 'lakókártya' which included the right to work after Hungary joined the EU. According to the view of an officer from the OIN in 2007, about 20,000 Romanians applied for five-year residence permits in Hungary and the majority were granted. However, no one actually checks whether the recipients of such permits really work in Hungary and it is implied that instead they only use this provision to transit Hungary legally.

With the expansion of the Schengen zone Hungary will probably increase its role as a transit country. Romanians of Hungarian ethnicity would prefer to move further to the West ... The information obtained shows that Romanian migrants received 5-years residence permits but when checked they turn out not to have resided in the place of registration for many years (expert from the OIN, February 2008).

The series of survey panels in 2004-2005 and 2008-2009 conducted in Romania supported the observation that only ethnic Hungarians still have some interest in migration and intention to migrate to Hungary as a place for work and residence. Nevertheless, this intention depends on their occupation and level of education. 
Recent surveys conducted in Romania (Kiss 2007; Gördi \& Kiss 2009), however, suggest that ethnic Hungarians who live in villages and towns with a mixed population have increasingly non-ethnic networks. In particular, they have begun joining Romanian migration networks and are now also moving to western or southern European destinations. According to these surveys the role of Hungary as an attraction to potential ethnic Hungarian migrants is diminishing. Nevertheless, the surveys for 2002 and 2009 in Romania also highlight the fact that family and kinship networks play an increasing role in migration to Hungary. The majority of ethnic migrants that arrived in Hungary (89 per cent) indicated different forms of assistance through the personal contacts either from migrants who arrived early in Hungary or persons who were born in Hungary (Gördi 2010: 27).

Being ethnically Hungarian opens up opportunities for people from surrounding countries to settle in Hungary, though this is less and less utilised. Vice versa, people of ethnicities other than Hungarian have fewer career opportunities and as a consequence lose interest to migrating to Hungary. Thus, the absence of ethnic capital among migrants from Romania is not compensated through social capital.

\section{Education migration}

Ethnic migration is also well represented and visible in the higher education sector. The internationalisation of education in Hungary is marked by a relatively modest rise in the number and variety of countries of origin of students. In 2008/2009, there were 16,299 foreign students out of about 400,000, or 4.1 per cent of the total (MoE 2009). Students from Romania, Ukraine, Slovakia and Serbia constituted 42 per cent of all foreign students. Their share has been increasing over the years according to data from the Ministry of Education.

Conditions to stay after graduation from Hungarian higher educational institutions are strict and even genuine students who graduate from Hungarian institutions but have no immediate job contract in Hungary are not able to stay for some months to find work in the country. Interviews with alumni who managed to remain and work in Hungary indicated their low level of integration into Hungarian society; also it turned out that many were ready to migrate to another Western country, especially Englishspeaking countries, thus a certain potential for onward-migration became apparent in this group (Molodikova 2008). 


\subsection{Illegal migration in the Schengen zone: Old or new migration patterns?}

During the early 1990s, after the collapse of communism, Hungarian migration policy underwent systemic change when the country adopted a very liberal entry system. As a consequence, Hungary became a target for both irregular and transit migrants who attempt to pass the western Hungarian border with Austria. In 2006, the year before Hungary joined the Schengen zone, irregular migration dropped by 10 per cent as compared to 2005, to 16,508 known cases. One explanation given was that this decrease was due to efficient control and enforcement measures (ICMPD 2007). More than half (62 per cent) of all apprehensions in Hungary before Schengen were made along the western borders at the Austrian border section, the then external border of the EU, but in 2007 and 2008 this number decreased because of improved border control (table 7.2). The number of illegal migrants who were caught on the eastern border of Hungary was on average only a third of the number of illegal migrants stopped on the western border (with Austria). This indicates the intensity of the westward migratory flow, but can also be partially explained by the much stronger migration control at the Austrian border (ICMPD 2007, 2010).

A comparison with a survey conducted in 1998 implies that the patterns of irregular migration and smuggling have since changed. In the late 1990s, human smuggling across the green border was dominant. Ten years later, smugglers more often hide irregular migrants in vans and vehicles as observed on the Romanian and Ukrainian border sections (IOM 2000). This is, to some extent, related to cross-border labour commuting between Hungary and its neighbouring countries (see table 7.3). Another difference is that in the late 199os, groups who were making clandestine border crossings consisted of up to ten individuals, whereas in the late 2000 s groups were smaller. Also the number of refusals of entry at different border sections of Hungary changed from 2002 to 2006; refused entry on the Austrian border decreased after 2004-2005 but slightly increased on the Ukrainian and Romanian borders. These changes can also be explained according to the improved control of the green borders (ICMPD 2010). 


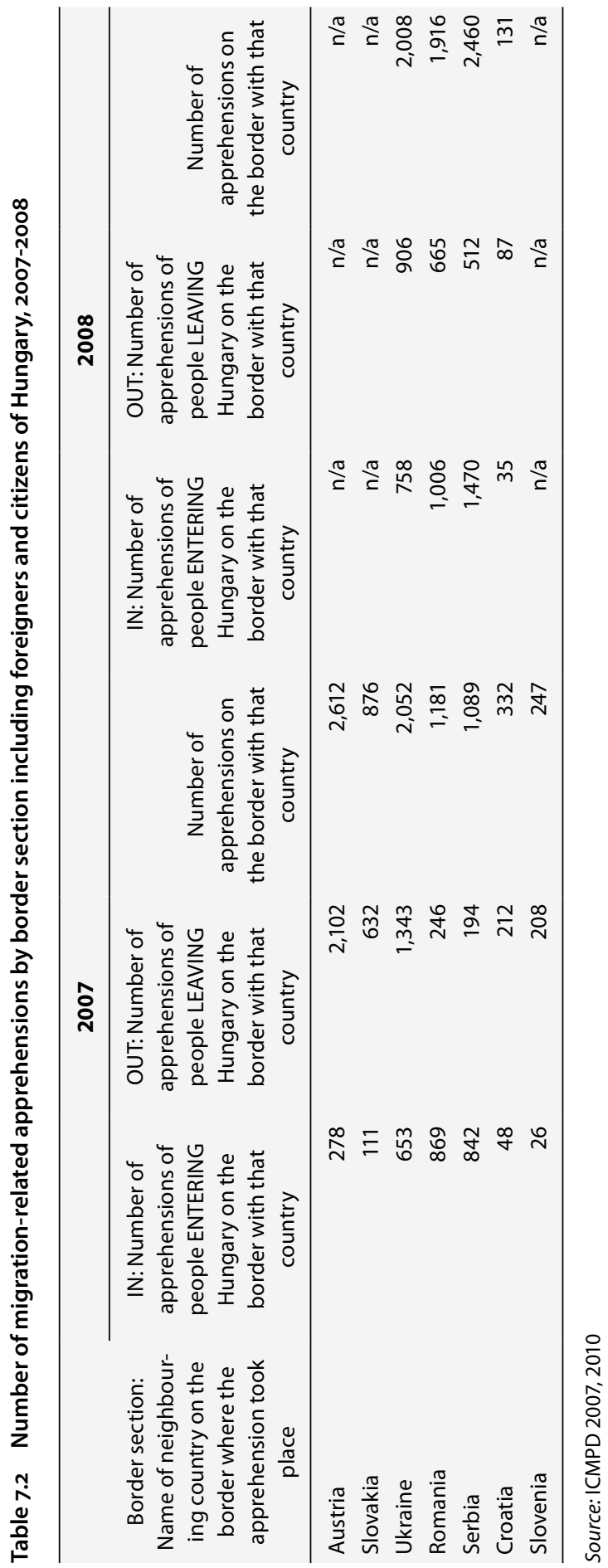


Table 7.3 Number of border violators apprehended in Hungary by place of apprehension

\begin{tabular}{lrrcc}
\hline & \multicolumn{4}{c}{ Number of apprehensions } \\
\cline { 2 - 5 } Place of apprehension & $\mathbf{2 0 0 5}$ & $\mathbf{2 0 0 6}$ & $\mathbf{2 0 0 7}$ & $\mathbf{2 0 0 8}$ \\
\hline On road border crossings & 1,106 & 10,394 & 5,794 & 6,790 \\
On rail border crossings & 637 & 387 & & \\
On green (land) border & 2,193 & 2,158 & 2,413 & 3,425 \\
At the sea border (river) & 17 & 10 & Not relevant & Not relevant \\
At airports & 303 & 254 & 492 & 434 \\
In the country & 2,848 & 2,866 & 711 & 1,284 \\
In other places & 66 & 74 & - & 47 \\
Total & $\mathbf{1 8 , 2 9 5}$ & $\mathbf{1 6 , 5 0 8}$ & $\mathbf{8 , 9 3 9}$ & $\mathbf{1 0 , 2 1 5}$ \\
\hline
\end{tabular}

Source: ICMPD $(2007,2010)$

Since 21 December 2007, Hungary has had a relatively short border with two non-EU countries, Ukraine and Serbia. Consequently, the Hungarian government came to the conclusion that it would no longer need large numbers of border guards (7,000 in 2007). Instead many of them were merged with the police and retrained and a concept called 'deep control behind the border' was established. ${ }^{4}$ In addition to that, the cross-border cooperation efforts were supported by different EU programmes related to ENI. For example, joint patrols of borders are implemented on the Hungarian-Romanian border. But for the Hungarian-Ukrainian border, a Hungarian border guard complained that it is difficult to organise operational cooperation with Ukrainians: 'With Ukraine we use only high-level cooperative contacts - phone-call-based relations' (from interview with border guard officer 17 February 2008). Three years later, in 2010, Human Rights Watch (HRW 2010) assessed this cooperation as well developed, whilst Ukrainian border guards on the Hungarian-Ukrainian border section explained that they only have a low and very formal level of cooperation with their Hungarian partners (interview in 2010).

In order to regulate regional cross-border movements of people, a special petty traffic border zone 'kis határ forgalmi' with special visa regulations was established for residents from both sides in 2008.5 This arrangement

4 'Deep control' means internal policing of highways, markets, and other areas where irregular migrants are suspected to be.

5 From 2007 for Ukraine and Hungary and Ukraine/Poland and Hungary with Serbia, and from 2009 for Moldova and Romania. 
aims to facilitate cross border movements of the large ethnic Hungarian population that settled within a $5^{0} \mathrm{~km}$ zone in the neighbouring countries. This innovation was negatively evaluated by Ukrainian experts and the population. According to them, it has actually become more complex and difficult to obtain an employment visa, which is considered a negative result of Hungary's accession to the Schengen zone. The consequence is that this special petty border visa is valid only for this zone, which happens to be poorly developed so that people do not find jobs there. The system for obtaining this particular type of visa is even more complicated than that for a Schengen visa, which is why locals prefer to get Schengen visas instead to seek jobs in $\mathrm{EU}$ countries. However, the petty border visa is also used legally to get into Hungary but then transit to other countries.

Many of my neighbours use ... the 'kis határ forgalmi' document and go to other countries to work ... there are no proper jobs in this $50 \mathrm{~km}$ area for us ... I have a work visa, but of course the place of work is faked. I am not going to work there. For a fee, a Chinese businessman organised everything for me (Ukrainian woman who lives in the border region, January 2008).

Over the past years, for Ukrainians the situation has improved, though not because of improvements of the visa service itself but because of the Hungarian policy to support ethnic Hungarians abroad. The local population was given the opportunity to obtain a five-year Schengen visa based on Hungarian ethnic cards. This liberalisation of the border regime for coethnics seems to facilitate increasing border violations by citizens of other CIS countries (Malynovskaya 2009). This is related to the visa-free travel regime of the CIS countries, which also grants citizens of these countries the right to stay in Ukraine visa-free for 90 days. These CIS migrants also took an interest in and utilised the opportunities of liberal visa regime meant to be for Ukrainian border zone populations only. As one local citizen reported in an interview, his friends from Georgia incessantly ask him to organise his family registration in this zone in order to also obtain these petty border traffic documents.

After Hungary's accession to the Schengen zone, the EU financed the improvement of the passing capacities of border check-points with third countries. This has both positive and negative effects: shorter waiting times for cars and the future development of private passenger minibus services are positive results. Nowadays regular private bus connections already link all regional centres of Ukraine with many regional centres of Europe (the Czech 
Republic, Italy, Spain, Portugal, Germany, Poland, etc.). This, however, also has negative side-effects. The rise in the intensity and number of small buses commuting is so high that, according to experts from the regional branch of the Ukrainian Institute of Strategic Research, twice a week the border guards have to organise a special lane at check points for these small buses. This facilitates the quicker passing of minibuses carrying people and goods across the borders. An unofficial 'tax' of about $€ 200$ per minibus is requested from the drivers; this also includes a request for no further declaration of goods normally taken from West to East. Vice versa, the regular weekly East-West commute creates a transit corridor for people and goods flows.

\section{Eastern vector offlows of illegal migrants}

In 2006, Ukraine ranked amongst the top three countries, together with Turkey and Hungary, with respect to the number of migration-related border apprehensions (respectively, 12,363, 51,983 and 15,219) (ICMPD 2007). The country is said to be one of the hubs in human smuggling activities. Ukrainian anti-smuggling police estimated that they detected only 20 per cent of those trying to cross the western border (Franchetti 2008). In the case of Ukraine it seems that assisting people in illegally crossing borders has become a thriving business which involves citizens from all walks of life as well as officials at all levels. A smuggler explains, 'getting an illegal from his home village somewhere in South-East Asia all the way to Europe is complex. There's a huge organisation behind it all, which in the Ukraine involves dozens of people' (Franchetti 2008).

The EU, as a donor, invests significant financial resources in the strengthening of the Ukrainian border. For example, the total EU funds for Ukraine from 1991 to 2004 amounted to $€ 1$ billion. From 2007, a Ukrainian programme on border management development cost the USA and EU about $€_{1}$ billion. ${ }^{6}$ In addition, FRONTEX joint operations to control the EU's eastern borders were calculated at another €992,500 (HRW 2010). These funds do not include other EU activities with similar aims. Unfortunately, flourishing corruption in all state structures in Ukraine supports the illegal migrants' flows. A Ukrainian migrant in Hungary who lives in a village in the border area revealed that

My relative is involved in this business. He is a border guard. He bought this position for $\$ 5,000$ and of course he wanted the money back. He told

6 Söderköping Process (2007), € tionpanel.org/page14769.html?template=print. 
me that at the top level they demanded money from operational border guards and if he wants to work he has to pay ... I know that many people around us in the villages are involved in this business (interview with a Ukrainian labour migrant, 17 March 2008).

According to information from smugglers, migrants pay from $£_{5}, 000$ to $£ 10,000$ for the journey from the non FSU Asian region to the EU. The fees paid by migrants are divided amongst several actors, notably smugglers, border guards, drivers and minders. In an interview with Franchetti (2008), a Ukrainian smuggler explains that he is paid $£_{500}$ per illegal immigrant, of which he keeps only £10o. Hence, the bulk of the money goes to his accomplices on both sides of the border.

The human smuggler claimed to be part of an international criminal network that routinely pays off guards on Ukraine's borders:

'Senior border guard officers are bribed', he said. 'I'm given a so-called "window" - a time and a place when a particular stretch of the border won't be patrolled, ... not all border guards are corrupt, of course, but we have no problem finding enough who are willing to turn a blind eye' (Franchetti 2008).

Whilst Kiev and Odessa seem to be the national hubs in irregular transit migration, migrants also mention some regional centres in the border regions, such as Lvov, Uzhgorod and Mukachevo. Smugglers usually conceal migrants in cellars and abandoned farmhouses before guiding them across the border. A senior Ukrainian police officer confirmed that 'people in villages along the border have been involved in smuggling illegal immigrants across the border for years. It's their main income' (Ukrainian senior police officer, 20 October 2008).

The next staging post in the transit migration process is Hungary, where similar practices were observed. Sometimes appartment owners do not even know how their apartments are being used. A Ukrainian interviewee and landlord of apartments in Budapest experienced the following in 2006:

[In 2006], I let out the apartment to Ukrainians. One day my neighbour from that apartment gave me a call and told me about strange people in the flat. I was shocked when I found about 15 Asian people (Ukrainian emigrant in Budapest, July 2007). 
Research carried out by the author suggests that citizens from FSU and non-FSU countries have developed different strategies for getting to the West. Citizens from Asian and African countries usually need a visa in order to enter and stay in Ukraine, and they are frequently checked by the various law enforcement bodies (Düvell 2008). In contrast, travellers from the FSU do not need a visa to stay in Ukraine. They are less visible and thus less troubled by the police. Many have networks of relatives or friends, dating back to Soviet times, who assist them in getting a temporary residence permit. This enables them to apply for a visa to the West in Ukraine or alternatively to purchase a ticket to an African country travelling via an EU country where they can apply for asylum. Certain agencies provide visas and arrange international travel, and these are widely known in Ukraine.

I visited my aunt in Kharkov. When we chatted she asked me if I wanted to go to work abroad and gave me the choice of three phone numbers. I called the first and that was a Lvov firm ... After almost one month I still had not received any response and complained to my mum in Russia. She had a friend in Kiev in the KGB [meanwhile rebranded SBU] and gave me his phone number ... I called him and complained that this firm may have cheated me. He contacted them [the firm] and threatened them that if I did not get a visa the firm could have problems doing business. The following day I received an employment visa (Russian migrant woman in Hungary, November 2007).

This example demonstrates the complexity of obtaining an illegitimate visa: the migrant needs to know the right person with information about agencies that deal with such matters, and he/she may also need access to someone in power to support the case. It also suggests that secret service staff may be involved in such matters. The evidence that the intervention of a KGB officer helped to get a working visa supports the supposition that the system of official internal registration for a temporary residence permit in Ukraine can also be used for the facilitation of visa applications, because foreign migrants need a residence permit in Ukraine to apply for a visa there. Refugees from Central Asia seem to have a similar experience though they face more obstacles:

It took about four months to organise my journey from Ukraine to Hungary ... It was difficult to find the right person who could help me. I travelled all across Ukraine searching in Kharkov, Uzhgorod, Lvov. I 
arrived in Kiev and went to the German embassy and told them that I was a refugee. They told me that it was not their business. I left in tears, crying and sat down on the stairs. A young man approached me and asked what I was crying about. He was ready to help me and registered me as his sister temporarily at his apartment. I lived in Kiev for one and a half months while he prepared all the documents for Hungary. I paid for a travel tour, got a visa and crossed the border (female refugee from Uzbekistan in Budapest, 17 January 2008).

The method of visa application was similar: (a) identify and contact facilitator; (b) obtain registration in Ukraine as a relative (for migrants from the FSU it is not difficult to claim that the person is a relative); and (c) find an agency that arranges the (tourist or other) visa and the trip.

Analysis of different cases provides evidence that irregular migration business at the EU's eastern border is a joint undertaking between official and unofficial structures (e.g., interior service registration, border guard services, mediators, travel agencies) and the local population. This creates an infrastructure and plenty of opportunities for transit migration to the West. Nevertheless, some positive facts were mentioned during the interview with the head of Migration Service in Uzhgorod/Zakarpattya. He said that the level of illegal migration in the crisis years declined, but he argued that it cannot be related to any success of the EU in controlling the situation but to a global trend in declining migration flows due to a decreasing demand for labour during the crisis.

\section{Southern vector: Evidence of illegal transit}

To the south of Hungary lies Serbia and the route of illegal migration through Serbia is also well established. Interviews conducted with migrants who passed through Serbia and Romania illustrate that they were transported through Turkey, Greece and Bulgaria until they finally turned up in Hungary near the town of Szeged close to the Serbian border. According to an IOM (2000) survey, about 25 per cent of the migrants detained at the Hungarian border for illegal entry used the territory of the Former Yugoslavia (FYU). Overland trips by van, bus, or car are particularly popular and were used in half of the authors' thirty interviewees' cases, mainly because flights or boat journeys are more strictly controlled. Often, there is a combination of means of transportation and lengths of journeys depending on money or the level of assistance by intermediaries (Düvell \& Molodikova 2009). Meanwhile, a readmission agreement has been signed with Serbia by the EU. In 2009, 
the cases of illegal migrants' transit clearly indicate that smugglers are constantly changing tactics and sometimes use very complicated methods:

We passed the Turkish border legally and had a flight to Belgrade. From Belgrade our instructor who is located in Ukraine and whom we contacted by phone told us to take a local bus to Montenegro, to Podgorica. We had no visa to this country but nobody checked us. There we took a local bus directly to Novi Sad [Serbia] and also nobody checked us. In this city we took a taxi and asked the taxi driver to take us where possible to the border. We passed through the forest and reached Hungary where we applied for asylum (women from Georgia, 17 July 2009).

This case highlights the international nature of the smuggling business. The Georgian family was managed by a Ukrainian trafficker by phone through Serbia and Montenegro. This made sense because at the time of their journey Ukraine had already adopted the readmission agreement and the risk of being returned to the country of origin was higher, especially for people from the FSU, thus the route through Serbia was safer.

An interview with a Serbian resident of the borderland zone reflects a situation similar to that described in interviews on the Ukrainian borderland:

The place I was born, near the Hungarian border, is very rundown. There are no jobs at all for the youth and I know that many of my former classmates work as smugglers of either goods or people. Of course, it is dangerous work. One of them was even captured, but they have to make a living. They have no other options (Serbian migrant, January 2008).

Several African interviewees mentioned that after being captured by Serbian border guards they had spent several days in a detention camp. They then tried to apply for refugee status in Serbia; instead, the Serbian border guards encouraged them to go to the West rather than applying for asylum. Subsequently, they were even directed to the Hungarian border, 'they gave us directions to the Hungarian border and told us it would be better to apply for asylum in an EU country' (Ethiopian migrant, June 2008).

In December 2009, visa controls were lifted on the Hungarian-Serbian border; this led to an increase in the transit of illegal migrants to and through Hungary. An expert from OIN Hungary responsible for asylum affairs stated that they have clear monthly data supporting the fact that as soon as the EU lifted the visa controls with Serbia - hence for Serbians 
and Kosovars (who are allegedly able to quickly obtain a Serbian biometric passport) - they went straight on to Germany and Scandinavia to ask for asylum. From that time, the number of asylum seekers in Hungary actually halved in 2010 (table 7.4).

Table 7.4 Asylum applications in Hungary and procedure: Persons transferred to Hungary

\begin{tabular}{lrrrrrr}
\hline Number of applications for asylum & $\mathbf{2 0 0 5}$ & $\mathbf{2 0 0 6}$ & $\mathbf{2 0 0 7}$ & $\mathbf{2 0 0 8}$ & $\mathbf{2 0 0 9}$ & $\mathbf{2 0 1 0}$ \\
\hline $\begin{array}{l}\text { Total } \\
\text { Percentage of non-Europeans of all }\end{array}$ & 1,609 & 2,117 & 3,419 & 3,118 & 4,672 & 2,104 \\
asylum seekers & $64 \%$ & $70 \%$ & $66 \%$ & $43 \%$ & $44 \%$ & $73 \%$ \\
$\begin{array}{l}\text { Entered the country legally } \\
\text { Entered the country illegally }\end{array}$ & 569 & 586 & 595 & 239 & 196 & 63 \\
$\begin{array}{l}\text { Dublin procedure: Persons transferred } \\
\text { to Hungary }\end{array}$ & 159 & 1,531 & 2,824 & 2,879 & 4,476 & 2,041 \\
\hline
\end{tabular}

Source: Office for Immigration and Nationalities www.bevandorlas.hu/statisztikak.php

\subsection{Transformation of migration flows after Schengen extension}

In fulfilling the Schengen obligations, Hungary has strengthened its migration controls whilst opening a back door, widely and warmly, for compatriots to enter the Schengen zone. This situation supports the illegal border crossings that have prevailed over legal entry across the entire period covered in this chapter (82.6 per cent). In addition, the level of applications for asylum has been constantly increasing from 1,60o in 2004 to 4,672 in 2009. However, in December 2009, visa-free travel between Serbia and Hungary was introduced, which resulted in changes in the flows of asylum seekers to many countries. In Hungary, as mentioned above, the number of applications halved in 2010. In contrast, an overall rise in the number of people seeking asylum (especially Serbs, Kosovars and Macedonians) was reported in Sweden, where the number of asylum seekers in 2010 reached 31,901 compared to 24,232, in 2009, including 6,343 Serbs, Kosovars and Macedonians (United Press International 2011). A similar situation was reported in Germany (Netzwerk Migration in Europa 2011; Migrationsrecht. net 2011), where Serbs rose to third position among the top three nationalities of asylum seekers, followed by Kosovars and Macedonians. These facts clearly demonstrate that Hungary functions as a transit country. As 
a consequence of the drop in the number of European asylum seekers, the number of non-European applicants from Asia and Africa in Hungary exceeded the number of asylum seekers from European countries. Afghan and Palestinian people are among the three top groups of countries in terms of origin of asylum seekers (table 7.5).

Table 7.5 Changes in the number of asylum applications by main nationality in Hungary, 2009-2010

\begin{tabular}{lrrrr}
\hline Nationality & $\begin{array}{c}2009 \\
\text { (persons) }\end{array}$ & $\begin{array}{l}\text { Percentage of } \\
\text { all applications }\end{array}$ & $\begin{array}{c}\text { 2010 } \\
\text { (persons) }\end{array}$ & $\begin{array}{l}\text { Percentage of } \\
\text { all applications }\end{array}$ \\
\hline Kosovo & 1,786 & $38.23 \%$ & 379 & $18.01 \%$ \\
Afghanistan & 1,194 & $25.56 \%$ & 702 & $33.37 \%$ \\
Serbia & 536 & $11.47 \%$ & 67 & $3.18 \%$ \\
Georgia & 116 & $2.48 \%$ & 68 & $3.23 \%$ \\
Turkey & 114 & $2.44 \%$ & 59 & $2.80 \%$ \\
Somalia & 75 & $1.61 \%$ & 51 & $2.42 \%$ \\
West Bank and & 23 & $0.49 \%$ & 225 & $10.69 \%$ \\
Gaza & & & & \\
Other & 828 & $17.72 \%$ & 553 & $26.28 \%$ \\
\hline
\end{tabular}

Source: Office for Immigration and Nationalities www.bevandorlas.hu/statisztikak.php

During the years after the EU accession, the procedure of asylum has become much stricter and, by and large, recognition rates of asylum seekers are very low, although due to a mix of reasons they have successively increased from 3 per cent (HHC 2003) to 11.7 per cent (HHC 2010). It is noteworthy, however, that according to an OIN expert from the Asylum Seekers department, many people abscond during the course of the procedure, thus their claim is rejected, which decreases the recognition rate. But if one only considers the recognition rate for those who stay in Hungary until the end of the procedure, the rate is actually 27 per cent (Lászlo 2011). As early as the 1990s, the phenomenon of absconding asylum seekers was mentioned in several surveys (HHC 1999; IOM 200o); then, about two thirds of migrants in refugee camps usually continued their journey to the West. The research that was conducted by IOM in 2000 noted that about 75 per cent of applicants disappeared during the time of evaluation. The situation nowadays is very similar to that in 2000. According to IOM data (2011), among a total of 4,672 persons in 2009 and 2,104 persons in 2010, interruptive decisions were conducted for 1,360 and 698 respectively. This constituted about 75 per cent of the total number of applicants. According to OIN expert information, the main reason for such an interruptive decision was the absconding of applicants 
during the procedure. Thus, many applicants' behaviour has not changed during the last 20 years. Representatives of the refugee camp administration have the view that Hungary's accession to the Schengen zone has actually made it easier for these people to travel within the EU.

Before enlargement, the Hungarian Helsinki Committee (HHC) believed that the insufficient and limited asylum legislation facilitated irregular migration:

There was a lot of evidence that the asylum policy in Hungary pushed people applying for asylum to illegally travel further west. The policy is not aimed at integrating refugees. Hungary has remained a transit country for asylum seekers and migrants ... more asylum seekers disappear during the procedure (HHC 2003:3).

At that time there were only two categories of protection: asylum seekers and 'refugees' and persons 'authorised to stay' (befogadó). The latter group has to remain in the country permanently, is not permitted to travel and has no access to social benefits. Due to the requirements in place for foreigners, they have to obtain permission for employment, but opportunities for legal work are limited. If a person's papers expire, their children can't attend schools. Some people lose jobs or are not able to get them legally. Before accession to Schengen in 2006, in addition to the previous two types of asylum seeker, the new law introduced a third category: 'subsidiary protection' - 'alkalmazott', that is, between refugee and humanitarian status.

Unfortunately, there is a significant gap between reality and the obligations of Hungary, as an EU member state, to uphold human rights and protect refugees and asylum seekers. This can be partly explained as resulting from a scarcity of funds. A positive achievement, however, is the new accelerated procedure for applications, which now must not take more than 90 days. However, its implementation requires the asylum seekers to stay in closed detention centres during the first stage of screening, which has negative psychological consequences. The new regulation on asylum seekers came into force in January 2011 and clearly shows Hungary's commitment to reducing asylum applications by using as a deterrent the prospect of the detention for 12 months during investigation processes.

All the people, who ask for asylum, have the experience that they are under arrest. They feel that they are in prison there. They don't under- 
stand why it is happening with them. So, they try to run away from there. Sometimes the procedure takes longer, weeks, months. Inside, there is no school, or shop. Children are also locked in (interview with NGO social worker, March 2010).

After the screening procedure the applicants are released into open camps where asylum seekers spent a minimum of 6 months. But conditions are not sensitive enough to religious, political or cultural tensions. Over the last two years there were several protests by asylum seekers in Hungary. The UNHCR report (2009) on Refugee Homelessness in Hungary says about integration:

There is no government agency with a statutory responsibility for refugee integration at community level. These cannot provide solutions to what are often structural problems of integration requiring a strategic, crossdepartmental response.

Integration of persons authorised to stay with humanitarian status is even more complicated. This is because their residence permit is valid for only one year and every year they have to renew their humanitarian status; they can spend years in this situation. In addition, they need special permission for working, which is a considerable bureaucratic undertaking. Usually, the duration of the processing time is counted into the time of the work permit. Thus, a vicious circle emerges that they are unable to overcome, of applying for prolongation of their humanitarian status and applying for work permits.

Most of the refugees, once their status is recognised, seem to leave the CEE countries and move to other EU states. ${ }^{7}$ Most of the asylum seekers' destination countries are England, France, Germany or the Netherlands, often because they have family there or there are large diasporas. Many asylum applicants, once released from detention, also believe that is the right moment to leave Hungary. Sometimes, they disappear for good but sometimes they are sent back. Notably when they claim asylum in other EU countries and the authorities discover they already had a status in Hungary, they are usually returned under the Dublin II Convention.

Thus, the implementation of the Dublin II Convention creates circular flows of asylum seekers in the EU. From 2005-2010, 2,681 persons were

7 Though there is no statistical database for all CEE countries on how many asylum seekers and refugees stay in the country and how many disappear from the camps, after rejection or after their toleration status is withdrawn. 
returned to Hungary, mainly from Germany (261 in 2009 and 198 in 2010), France (229 in 2009 and 100 in 2010) and Austria (159 in 2009 and 194 in 2010). Consequently, Hungary too returned Dublin II cases to other EU countries 261 persons for 2009-2010, mainly to Greece and to Romania (table 7.6).

Table 7.6 Dublin procedure: Received by Hungary from another member state by nationality of asylum seekers and sent by Hungary to another EU member state

\begin{tabular}{|c|c|c|c|c|c|}
\hline \multirow{2}{*}{$\begin{array}{l}\text { Country of } \\
\text { nationality } \\
\text { of asylum } \\
\text { seekers }\end{array}$} & \multicolumn{2}{|c|}{$\begin{array}{l}\text { Received by Hungary from } \\
\text { another member state by } \\
\text { nationality of asylum seeker }\end{array}$} & \multirow{2}{*}{$\begin{array}{l}\text { Country } \\
\text { responsible } \\
\text { for the } \\
\text { asylum } \\
\text { procedure }\end{array}$} & \multicolumn{2}{|c|}{ Actual transfers } \\
\hline & 2009 & 2010 & & 2009 & 2010 \\
\hline Kosovo & 409 & 218 & Greece & 16 & 120 \\
\hline Serbia & 182 & 79 & Romania & 15 & 20 \\
\hline Afghanistan & 110 & 217 & Austria & 13 & 2 \\
\hline Georgia & 40 & 52 & Poland & 8 & 3 \\
\hline Other & 193 & 176 & Other & 32 & 32 \\
\hline Total & 934 & 742 & Total & 84 & 177 \\
\hline
\end{tabular}

Source: Office for Immigration and Nationalities www.bevandorlas.hu

In addition to that, the number of assisted returns to country of origin, which is based on an agreement between the IOM and the Ministry of Interior, has also increased. HHC criticised the Hungarian government for the implementation of the Dublin II procedure and for sending the applicants to Greece. Hungary has finally decided to stop this practice until Greece creates proper asylum legislation (table 7.7). 
Table 7.7 The number of return travels by country of origin, based on the Ministry of Interior of Hungary and IOM agreement for 2009-2010

\begin{tabular}{lcccc}
\hline Nationality & $\begin{array}{c}\mathbf{2 0 0 9} \\
\text { (persons) }\end{array}$ & $\begin{array}{c}\text { Percentage of all } \\
\text { applications }\end{array}$ & $\begin{array}{c}\mathbf{2 0 1 0} \\
\text { (persons) }\end{array}$ & $\begin{array}{c}\text { Percentage of all } \\
\text { applications }\end{array}$ \\
\hline Kosovo & 228 & $78.35 \%$ & 301 & $70.66 \%$ \\
Mongolia & 16 & $5.50 \%$ & 13 & $3.05 \%$ \\
Serbia & 11 & $3.78 \%$ & 1 & $0.23 \%$ \\
Macedonia & 8 & $2.75 \%$ & 4 & $0.94 \%$ \\
Turkey & 6 & $2.06 \%$ & 7 & $1.64 \%$ \\
Other & 22 & $7.56 \%$ & 100 & $23.47 \%$ \\
Total & 291 & $100 \%$ & 426 & $100 \%$ \\
\hline
\end{tabular}

Source: Office for Immigration and Nationalities, www.bevandorlas.hu

Finally, the readmission agreement with the non-EU neighbouring countries Serbia and Ukraine does not seem to be working properly, according to the opinion of an expert from the OIN office. In particular, because these cannot be accepted as safe countries, returns have to be carefully considered. This is especially the case when people smuggled, for instance, to Odessa, were hidden somewhere and did not get used to Ukrainian realities. And the Hungarian Helsinki Committee (2010) complained that the readmission agreement creates a ping-pong situation used by EU countries when people are not able to apply for asylum and can thus be sent back to Ukraine or to Serbia.

\subsection{Adaptation strategies of refugees and protected migrants: The results of three years' life in Hungary}

In order to evaluate the process of the integration of refugees and their success or failure, and to identify reasons for their possible on-migration, a pilot survey was conducted with 31 refugees and protected people - including those with a humanitarian status - from December 2006 to March 2007 and again in spring 2010 with the same sample. This was done to find out what happened to the people who got a different status of protection in the three years since they were first interviewed at the end of 2007, beginning of 2008. Thirty interviews were conducted with persons of different protection status; 11 were from Asia, 6 from former Soviet countries and 14 from Africa. Only eight people have families that arrived together, 17 
of the 30 interviewees obtained refugee status from the moment of their first interviews.

In 2006-2007, only two of all the respondents claimed that Hungary was their destination country. Many of the immigrants mentioned that the destination country was not specifically important, 'just Europe' was where they wanted to go. But others pointed to the UK, Sweden, Germany, Austria and Switzerland as their destination countries. They indicated these countries because they had relatives and friends there and expected their help. We classified the interviewees into five groups based on their future plans:

1 Those who would wait and remain to see if they obtained legal status: 'It depends on what the authorities decide: if I get refugee status, I will stay here, learn Hungarian and get a legal job. If I don't get status, I will go.'

2 Those who wanted to go to the West even if they got status: 'If we have a legal job and all official papers, we will try again to get a visa to England'.

3 Those who planned to remain in Hungary because of a Hungarian spouse or partner: 'I don't want to go to another country. I want to marry my boyfriend'.

4 Those who would remain in Hungary because of family reasons: 'children need to go to school'.

5 Those who were undecided whether to stay or to go: 'stay here and live a legal, normal life or leave for Italy or France.'

Some of the immigrants planned to stay in Hungary for two to three years, learn Hungarian and find a regular job, especially those few people who had Hungarian partners. Those who had children were concerned about schooling. Other interviewees, however, who were waiting for new documents or who were without children, were not so determined to stay in Hungary. Notably language remained the main problem, especially with finding jobs. For example, some migrants thought that the solution was to go to Sweden to their relatives, but they soon returned to Hungary:

Four months after arriving, we organised a journey to Sweden. My sister is living there. We left Hungary in June, but in August we came back because we couldn't legalise our residency permit there: we couldn't get a work permit, nor school for the children (Iraqi refugee, February 2008). 
Internet and mobile phones now enable people to very quickly acquire information and asylum seekers know well the best places to apply for asylum or to find jobs when passing through other EU countries:

All these persons tried to find jobs in Hungary during the first year but this turned out to be difficult due to their lack of language proficiency, as well as due to a lack of social support. Social workers from the NGO Menedek have doubts about the immigrants' plans to stay, 'immigrants always say that they are planning to stay, but the most difficult time they face is after they have obtained legal status. The reality of life pushes them to go west' (Menedek NGO's social worker, March 2008).

Indeed, migrants and refugees only had limited sources of support in Hungary from the government, a few NGOs and some churches. That is why they thought that the solution was to join their relatives or acquaintances in other countries, who promised jobs or support.

I am going to Sweden, because I know from my Iraqi acquaintances that in Hungary the conditions in the camps are very bad and the provision is very poor. I have relatives in Sweden and they promised to help me (Iraqi migrant who was travelling through Hungary to Sweden, April 2008).

Three years on, some positive and negative changes have happened in the lives of people with humanitarian status called befogado. For example, five out of 14 people changed their status from humanitarian to subsidiary protected or to refugee (alkalmazott). Unfortunately, such positive changes only affected African people. Among others with humanitarian status we should consider some negative changes: two of three families from the former socialist countries left Hungary for other countries in the EU; one family resettled in Slovakia and the other family fled to Austria. A third family, after staying in Hungary for eight years with a humanitarian status, was awaiting deportation; the HHC had been representing them in court based on the fact that one child is going to school and does not even speak the language of the country of origin. The tragedies of such people are evident.

Another finding is that only 13 of the original 30 interviewees were still in Hungary after three years. The others had either disappeared or we had information that they now work in other countries. Two of them reached the UK, illegally. One man regularly commutes between the UK and Hungary and his family wants to resettle there as soon as their child 
has finished school. So, of those 13 families who still lived in Hungary, eight (more than half) nevertheless worked for shorter periods, 3 months to one year, illegally, in a Western country. According to their stories they usually used the network of the refugees and asylum seekers that they became acquainted with during their months in the camp. From time to time they returned to Hungary, though for different reasons: because (1) they were sent back by the authorities of another country; (2) they needed new papers; (3) for family reasons; or (4) due to health problems. After the Schengen zone was expanded to the east, new circulation flows of refugees and other protected people between Hungary and Western countries were observed. Usually people did not want to return, but they had to when their documents expired or because of some urgent needs.

\begin{abstract}
Almost all refugees I had known went to the West when passports were issued for two years; now, the police changed the rules and they are issued for only one year ... But people usually return for papers and go back (interview with an advocate, April 2010).
\end{abstract}

The circulation of job-seeking refugees trying to support their families has become a new phenomenon since the extension of the Schengen zone to the east. This is because the new member states (NMS) offer few opportunities for integration into the labour markets or society as a whole. They use their networks to access the diasporas in other countries. In one interview with a female refugee, the informant described how for one and a half years, her husband had been unsuccessful in finding a job in Hungary. As a consequence, he and his 20-year-old son took the long journey through Germany and some other Northern countries to go to the UK illegaly without a visa; for this undertaking they were receiving support from some acquaintances they had made in the refugee camp. Several times, they travelled to the UK without visas. In the UK, they worked irregularly and rented rooms from Lithuanian migrants. Only when the husband needed some urgent surgery did he have to return to Hungary; his son, however, still lives and works in the UK. Meanwhile, the son's family is also planning to move to the UK as soon as the youngest child has finished Hungarian school. It seems that since the expansion of the Schengen zone, this kind of circular transit has become a new reality of migration within the EU.

Summing up, one could say that the only group of migrants that is not going to leave Hungary consists of people who have local spouses or partners. These are typically Africans; among the 30 cases, six had Hungarian partners or wives. Thus they also had better chances to learn Hungarian 
and to get access to housing and jobs. All of them had either refugee or subsidiary protection status. The other 24 people complained that they do not see a future in Hungary because there are few opportunities to find jobs and to support themselves. In addition, the impact of the financial crisis on Hungary's economy has further undermined their desire to live in Hungary.

\subsection{Integration plans as officials see them: New laws and new opportunities}

In the 1990s, the Hungarian system of asylum protection had an ethnic dimension and put particular emphasis on the Hungarian minorities abroad. After 1998, amendments were made to the Refugee Law; now Hungary accepts refugees not only from Europe but from all over the world. Nevertheless, officials still have strong feelings about ethnic Hungarian immigrants and believe that they should be prioritised. A survey conducted in the various Hungarian ministries (Molodikova 2005) generally revealed the perception that 'Hungary does not expect and does not need migrants other than ethnic Hungarians in our country' (from numerous interviews in April 2005). This conclusion is also confirmed by the report of the Hungarian Helsinki Committee:

Hungarian authorities do not intend to integrate people granted a stay status. The aim of the asylum policy concerning such persons is to see them returning to their country of origin as soon as possible ( $\mathrm{HHC} 2003$ : 3).

Meanwhile, Hungary is nevertheless gradually becoming a recipient country for non-Hungarians. Though the country does not allocate or have sufficient funds to implement the new legal provisions for refugees and immigrants of other statuses:

The new 'alkalmazott' status will give many immigrants a new opportunity for a normal life. But unfortunately the government simply has no money for the reforms they started (interview with HHC, March 2008).

On the one hand, Hungary, against strong public opposition, has gradually improved immigrants' legal status and the social position of refugees and protected people, which should increase the propensity of legally protected migrants to actually stay in the country. Nevertheless, the reality of life is 
more complicated for non-Hungarian migrants and they are not particularly welcome in Hungary. In addition, experts mainly agree that Hungary has a high degree of xenophobia toward migrants (Hárs 2008; MIPEX 2007, 2010). Such conditions are not conducive to immigrant integration, which is why non-Hungarian migrants generally do not aim to stay in Hungary. Finally, free movement within the Schengen zone is a strong incentive for immigrants in Hungary to move on to other destinations.

In the mid-200os, a migrant management strategy was proposed and there was a thorough assessment of the future professional, economic and social needs of the country's work force. The conclusion was that in order to improve its economic performance, Hungary required an increasing number of immigrants. The suggestion was made that many immigrants were likely to come from non-neighbouring countries. This was heavily criticised by the political opposition for being pro-immigrant and neglecting the interests of the Hungarian minorities in neighbouring countries. ${ }^{8}$ Thus, after heavy opposition by the media, the draft strategy was withdrawn and the policy failed. In the eyes of an official from the Ministry of Justice, this is a dilemma:

There is no such law in Hungary on integration. Refugees now have three years, legal status and some social assistance related to this status. Other migrants don't get this assistance, but they need to be integrated (Official from the Ministry of Justice, May 2008).

In 2008, as part of the Migration Management Strategy, the Hungarian Parliament intended to introduce a law on integration. An official from the Ministry of Justice concluded with resignation, 'if we want to pass a law on integration in parliament we have to be very ingenious, because of political interpretations of it by the opposition' (official from the Ministry of Justice, May 2008). At present, the new right-wing ruling coalition has clearly indicated the political course of attracting ethnic Hungarian immigrants. Meanwhile, their selective integration offers few opportunities for migrants of other ethnic backgrounds to live in Hungary.

8 In fact this strategy was indeed pro-immigrant, but not more so than most Western European countries' migration policies, as can be seen from the calculations it makes on population changes and workforce needs. The strategy can be found at the website of the Christian Democratic Party, which criticized it most heavily (www.kdnp.hu/index.php?type=cikk\&cikkid=1544). 


\subsection{Conclusions}

The analysis of the situation in Hungary and the surrounding countries gives rise to some conclusions about the key features which facilitate transit migration through Hungary. The first, essential, characteristic is Hungary's geopolitical location. For more than 20 years, Hungary has been a frontier for the Western European countries and shares borders with major migrantsending countries of Europe, such as Ukraine, Romania and Serbia. But this feature is not the only explanation for the high level of transit migration in Hungary. It is compounded by a wide range of legislative, geographic and cultural features which make controlling migration flows in Hungary a difficult and complex task.

The selective (or exceptional) liberalisation of the visa regime between Hungary and the surrounding countries, which includes ethnic cards, petty border traffic zones and dual citizenship, creates asymmetric relations with neighbouring non-EU countries. This prompts various flows of migrants into Hungary. There are huge gaps in the levels of economic, political and cultural development between EU and non-EU countries. The economically poor regions surrounding the EU borderland are characterised by flourishing large-scale corruption in all state structures, from top to bottom. This corruption is quintessential for the organisation of illegal transit migration, for instance, through Ukraine to Hungary. The evaluation presented in this chapter of the border-passing strategies in the eastern and south-eastern sector of the EU borderland clearly highlights the existence of illegal migration and therein the proportion of transit migration. Liberalised visa regimes provide ample opportunities for migrants to cross borders legally, but then visa conditions are ignored and often the visa holders remain in the country, seek work on onward travel or apply for refugee status somewhere else, in one of the more developed Western countries.

Transit flows through Hungary are also stimulated by Hungarian ethnic policy. Hungary made considerable amendments to its migration regulations which resulted in the liberalisation of migration policy for ethnic Hungarians who live in neighbouring third countries. Almost one million third-country nationals - and soon also their relatives - are thus able to benefit from some Schengen visa liberalisation. In fact, Hungary externalises this influence and expands the opportunities for migrants' movement to and through Hungary. The lifting of the visa regime with Serbia led to a further increase in the transit flow through Hungary.

Once a migrant reaches Hungary, the strengthened migration policy towards third-country nationals and asylum seekers facilitates transit flows 
of migrants. The flaws in the refugee status determination and integration processes facilitate high levels of absconding of asylum seekers, who usually move west to other EU countries. Further to this, the implementation of the EU's Dublin II regulation in Hungary and the readmission agreements with non-EU countries have facilitated some involuntary circulation of migrants, supported by officials of all EU countries. Asylum seekers now try again and again to cross the borders and are sent back to another EU or non-EU country. This mainly results in the return of migrants to Hungary from Germany, France and Austria, and from Hungary to Ukraine, Greece and Romania.

Underlying the decision of a migrant to remain in Hungary or to only use it as a country of transit is the presence or absence of social networks. Network theory suggests that settling down is only feasible for co-ethnic Hungarians from neighbouring countries who already have human capital in terms of language proficiency and social capital in the form of a network of compatriots. For other migrants, and particularly, for asylum seekers, the absence of compatriot networks in Hungary combined with the existence of such networks in other Western countries facilitates migrant transit flows. Such networks offer immediate social capital in the Western destination countries. In Hungary, there are few opportunities for settling down and integrating, particularly given the absence of any special integration policy and indeed actions against introducing any such policy. Our interviews with migrants suggest that the only chance for a migrant to settle is to establish a Hungarian family. The presence or absence of networks for a migrant is a key determinant in shaping Hungary's character as a transit flow country.

\section{References}

Castles, S. (2002), 'Environmental change and forced migration: Making sense of debates'. Working paper No. 70. Geneva: UNHCR Evaluation and Policy Analyse Unit.

Donnan H. \& Th.M. Wilson (2001), Borders Frontier of Identity, Nation and State. New York: Berg Oxford Press.

Düvell, F. (2007), Ukraine, Europe's Mexico? Oxford: COMPAS.

Düvell, F. (2008), 'Refugees in Ukraine'. Working Paper. Oxford: COMPAS.

Düvell, F. \& I. Molodikova (2009), 'Vvedenie', in F. Düvell \& I. Molodikova (eds), Tranzitnaia Migratsia I Tranzitnie Strain: Teoria, Praktika I Politika Regylirovania. Moskva: Akademkniga, 5-2o.

Fawcett, J.T. (1989), 'Networks, linkages, and migration systems', International Migration Review 23: 671-68o.

Franchetti, M. (2008), 'With most border controls in Eastern Europe now gone, people smuggling has become easy business in the Ukraine', 20 January, 2008, www.inosmi.ru. 
Gördi, I. (2010), 'The role of ethnicity and social capital in immigration to Hungary'. Working Papers on Population, Family and Welfare, No. 12. Budapest: Demographic Research Institute of Central Statistic Office.

Gördi, I. \& T. Kiss (2009), 'Migrációs hajlandóság, tervek és attitűdök az erdélyi magyarok korében', Spéder Zs. (szerk) Párhuzamok Népességtudományi Kutató Intézet, 183-219.

Gurak, D.T. \& F. Caces (1992), 'Migration networks and the shaping of migration systems', in M.M. Kritz, L.L. Lim \& H. Zlotnik (eds), International Migration Systems: A Global Approach. Oxford: Clarendon Press, 150-175.

Haas, de H. (2005), 'Morocco's migration transition: Trends, determinations and future scenarios'. Global Migration Perspectives 28. Geneva: Global Commission on International Migration.

Hárs, Á. (2009), 'Immigration countries in Central and Eastern Europe: The case of Hungary'. IDEA Working Paper No. 12. www.idea6fp.uw.edu.pl/pliki/WP12_Hungary.pdf.

Hungarian Border Guards (Határőrség Országos Parancsnoksága) (various dates), Database. www. hatarorseg.gov.hu/index.php?akt_menu=86\&PHPSESSID=ccb43a6d818bb3cefc22985co2cc991a.

HHC (Hungarian Helsinki Committee) (1999), 'Experiences of legal representation in asylum procedures in Hungary'. www.helsinki.hu.

HHC (Hungarian Helsinki Committee) (2003), 'Asylum in Hungary'. www.helsinki.hu.

HHC (Hungarian Helsinki Committee) (2009), 'Hungary among top five among EU member states who continue to return asylum seekers to Greece'. http://helsinki.hu/Friss_anyagok/htmls/797.

HHC (Hungarian Helsinki Committee) (2010), 'Stop Dublin returns of asylum seekers to Greece, demands HHC following milestone judgment by European Court of Human Rights'. http:// helsinki.hu/Friss_anyagok/htmls/797.

HRW (Human Rights Watch) (2010), 'Buffeted in the borderland: The treatment of asylum seekers and migrants in Ukraine'. www.hrw.org/en/reports/2010/12/16/buffeted-borderland-o.

Juhasz, J. (2003), 'Hungary: Transit country between East and West', Migration Information Source. Washington: Migration Policy Institute.

ICMPD (International Centre for Migration Policy Development) (2007), 'A survey and analysis of border management and border apprehensions: Data from 20 states', in P. Futo \& M. Jandl (eds) (2006), Yearbook on Illegal Migration, Human Smuggling and Trafficking in Central and Eastern Europe. Vienna: ICMPD.

ICMPD (International Centre for Migration Policy Development) (2010), 'A survey and analysis of border management and border apprehensions'. Data from 2008, in P. Futo \& M. Jandl (eds), Yearbookon Illegal Migration, Human Smuggling and Trafficking in Central and Eastern Europe. Vienna: ICMPD.

IOM (International Organization on Migration) (1994), Transit Migration in Hungary. Geneva: IOM.

IOM (International Organization on Migration) (1995), Irregular Migration in Central Europe: The Case of Afghan Asylum Seekers in Hungary. Migration Information Program. Geneva: IOM.

IOM (International Organization on Migration) (1997), Migration Patterns in Central Europe. Geneva: IOM.

IOM (International Organization on Migration) (2000), Migrant Trafficking and Human Smuggling in Europe: A Review of the Evidence with Case Studies from Hungary, Poland and Ukraine. Geneva: IOM.

Kimball, A. (2007), The Transit State: A Comparative Analysis of Mexican and Moroccan Immigration Policies. Working Paper 150. San Diego: University of California.

Kiss, T. (2007), Demográfiai Modellek és Migráció: Az Erdélyi Magyarokvándormozgalma a XX Század Utolsó Negyedében. Budapest: Regio 1, 160-189.

KHS (Központi Statisztikai Hivatal - Népességtudományi Kutatóintézet) (2010), Hungarian Central Statistical Office, Demographical Institute, www.demografia.hu/english/. 
Lászlo, S. (2011), 'Change in asylum legislation'. Paper presented at seminar Migration and Security. Budapest: Central European University, 2 March.

Malynovskaya, O. (2009), 'Transit illegal migration: Ukraine', in I. Molodikova \& F. Düvell (eds), Transit Migration and Transit Countries: Theory, Practice and Policy of Regulation. Moscow: Akademkniga Press (in Russian), 130-159.

Massey, D., J. Arango, G. Hugo, A. Kouaouci, A. Pellegrino \& E. Taylor (1993), 'Theories of international migration: A review and appraisal', Population and Development Review, 19 (3):431-466.

Massey, D., Arango J., Hugo, G., Kouaouci, A., Pellegrino, A. \& E. Taylor (1998), Worlds in Motion: Understanding International Migration at the End of the Millennium. Oxford: Oxford University Press.

Migrationsrecht.net (2011), 'Hauptherkunftsländer im Januar 2011', www.migrationsrecht.net/ nachrichten-asylrecht/1734-asylbewerber-statistik-januar-2011.html.

MIPEX (Migration Integration Policy Index) (2007), Hungary: Overview, www.integrationindex. $\mathrm{eu} /$ integrationindex/2403.html.

MIPEX (Migration Integration Policy Index) (MIPEX) (2010), Hungary: Overview, www.integrationindex.eu/hungary.

MoE (Ministry of Education and Culture) [Oktatási és Kulturális Minisztérium] (2009), Statisztikai Tájékoztató. Felsőoktatás (2009) [Statistics on Higher Education. Ministry of Education and Culture].

Molodikova, I. (2008), 'Mobility of students from NIS countries and Baltic States after the graduation of European Universities', in I. Molodikova (ed.), Migration Studies in the Context of Social Science. Smolensk: Magenta (in Russian).

Molodikova, I. (2009), 'Vengria: byfernaia zona dlia tranzitnoi migratsii' [Hungary as buffer zone for transit migration in the EU], in I. Molodikova \& F. Düvell (eds), Tranzitnaia Migratsia I Tranzitnie Strain: Teoria, Praktika I Politika Regylirovania [Transit Migration and Transit Countries Theory, practice and policy of regulation]. Moscow: Akademkniga Press.

Netzwerk Migration in Europa (2011), 'Deutschland: Mehr Asylanträge, geringere Schutzquote', Newsletter 1, January, www.migration-info.de/mub_artikel.php?Id=11010.

OIN (Office of Immigration and Nationality) (2007), Statistical data in English. www.bmbah. hu/statisztikak_HUN_34-2xls.

OIN (Office of Immigration and Nationality) (2009), Aliens Policing, Nationality, Refugee Affairs: Statistical Publication of the Office of Immigration and Nationality 2004-2008. www. bevandorlas.hu/statisztikak_HUN_36.xls.

OIN (Office of Immigration and Nationality) (2011), Statistical data. www.bmbah.hu/statisztikak. php.

Tóth, J. (2005), 'Towards a joint sweeper of illegal migrants', Central European Political Science Review 6 (19): 89 .

Tóth,J. (2010), Hungary: Changes in the executive rules to implement the recent amendment of the Citizenship Law. EUDO CITIZENSHIP, http://eudo-citizenship.eu/citizenship-news/371-hungarychanges-in-the-executive-rules-to-implement-the-recent-amendment-of-the-citizenship-law.

United Nations High Commissioner for Refugees (UNHCR) (2009), Being a Refugee: How Refugees and Asylum Seekers Experience Life in Central Europe. Geneva: UNHCR.

United Press International (2011), Rise in asylum seekers in Sweden, www.upi.com/Top_News/ World-News/2011/o1/04/Rise-in-asylum-seekers-in-Sweden-in-2010/UPI-63451294187086/. 


\title{
8 Irregular Transit Migration of Moldovan Citizens to the European Union Countries
}

\author{
Valerii Mosneaga
}

\subsection{Introduction}

Since the Republic of Moldova became independent in 1992, diverse peculiarities have shaped Moldova's migration flows. Moldova is one of several small newly formed states in Europe after the break-up of the Soviet Union and the Eastern bloc. Following a short civil war in 1991, Moldova was divided into two parts, the internationally recognised Moldovan Republic and the unrecognised breakaway territory of Transdnestria. The main industries are located in Transdnestria; Moldova is mostly agricultural. Hence, the Moldovan Republic has, as a consequence of the conflict, lost control of its industrial potential. In addition, because the internal conflict has also led to tensions with Russia, a subsequent Russian economic embargo on wine in 2004 almost destroyed Moldova's main export industry. The conflict also explains in part why Moldova is one of the poorest countries in Europe (UNDP 2006); indeed, 55.4 per cent of the population live below the poverty line (Milanovic 1998). ${ }^{1}$ Notably rural communities have experienced severe poverty; not just lack of money or even food, but also lack of opportunities. ${ }^{2}$ These conditions have forced the rural population in particular to abandon their life in the countryside and migrate to other countries in search of a better life.

As a result of the high level of poverty, Moldova has one of the highest rates of international migration; a survival strategy chosen by many in its population. Located in the south-east of Europe, Moldova is sandwiched between Romania and Ukraine. Both countries are among the main sources of labour migrants to the EU and have relatively low economic development and wages. Thus, they are not considered by Moldova's migrants to be attractive destination countries. Instead, the choice for Moldovans has always

1 The World Bank (2000) suggests that the absolute poverty line for the CIS countries should be $\$ 2$ a day.

2 For this definition of poverty see Walker \& Walker (1997). 
been either to migrate to the East (Russia) or to the West (EU countries). Russia offers a visa-free regime for CIS citizens and this partly explains why the main migration flow from Moldova runs in this direction. Nevertheless, in recent years migration flows have gradually re-routed west; this can be explained by the greater economic attraction of Western countries but also by the development of the migrant network in EU countries. At the same time, migration to the EU is complicated by the need to obtain a Schengen visa, which determines the various border crossing practices into the EU. Until December 2007, Moldovans travelling overland to EU countries had inevitably to transit non-EU countries, notably Romania and Ukraine, before EU territory could be reached. However, since Romania's accession to the EU, Moldova now immediately borders the EU. This fact has given rise to some negative processes - according to surveys on illegal migration and human smuggling (ICMPD 2007, 2010), Moldovans still transit through multiple CIS and EU countries in order to reach their destination. This article demonstrates how the process is organised. The study is based on empirical data and provides an analysis of migrants' journeys and trajectories of movements.

\subsection{The push factors of Moldovan migration}

In Soviet times, the population of Moldova was multiethnic. According to the last Soviet population census in 1989, the majority of the population (69.9 per cent) was Moldovan (or Romanian, according to ethnicity and language). Russians constituted 9.8 per cent, Ukrainians 11.3 per cent, and Gagauz, a Christian Turkish people, 3.5 per cent of the population. Russians and Ukrainians generally lived in urban settlements, predominantly in the breakaway region of Transdnestria, which is the most industrialised part of Moldova. The indigenous population was predominantly rural and was mainly involved in agricultural activities. The country's population is currently decreasing due to a significant migration outflow. By 2008, it had dropped to 3.37 million people; this does not include Transdnestria, which has a population of another 600,000 to 800,000 .

The conflict between Moldova and Transdnestria has had a dramatic impact on both the demography and the economy of Moldova. As soon as the country claimed independence and declared the priority of Moldovans over the other ethnic groups, conflict erupted between the Russian-speaking industrial region of Transdnestria and the rural, relatively agrarian remainder of Moldova. Transdnestria refused to recognise the new Moldovan 
state, and declared its own independence as the Transdnestrian Republic. This entity, however, is not recognised by the international community. Separatism in Transdnestria led to military conflict in 1992 and to the secession of the province; ethnic tension persists between the Russian and Romanian populations (Dressler 2004). The conflict was the first push factor for forced migration from Moldova, especially of the Russianspeaking population. The shrinking number of Russians and Ukrainians due to migration has led to an increasingly mono-ethnic structure of Moldova. As a result of the partition, the Moldovan state lost its main energy and industrial potential and has therefore suffered from energy shortages. Currently, Moldova has one of the lowest rates of urbanisation and 54 per cent of the population live in rural areas. Its economy is heavily dependent on the agricultural sector, in which more than $5^{\circ}$ per cent of the population is employed. Nature has appeared to conspire against the emerging country, with severe floods in 1992, 1994 and 2006, and problems of drought in 2000, 2004 and 2007.

Employment rates fell dramatically after the collapse of the USSR in 1989, which has affected all sectors of the population. In terms of fulltime jobs, unemployment was more acute for women than men. Women comprised 68 per cent of the total number of unemployed by the mid-20oos (ILO 2005). Moldova also had one of the highest youth unemployment rates in South-Eastern Europe, representing around 30 per cent of the entire registered number of unemployed (UNICEF 200o). Even for the employed population, the level of salaries was insufficient to meet the cost of living. These economic and political hardships stimulated a mass exodus to other countries in search of employment opportunities. Similar to migration in other CIS countries, the first type of labour migration was the so-called 'petty trade' migration, predominantly to Russia, Romania, Ukraine, Turkey and Poland. The difference in currency exchange rates, prices of goods and commodities between countries, in combination with the CIS visa-free space and cheap transportation, were among the driving forces for this type of migration (Dolghih 2003). But the economic crisis in Russia in 1998 undermined and finally ended this activity, simultaneously triggering an interest in EU countries as an alternative destination. The strengthening of visa regimes in Central European countries pushed Moldova's population from short-term, petty-trade migration into more long-term economic migration to more distant Western European countries and to Russia. In addition, the paucity of opportunities for legal incomes has pushed increasing numbers of Moldovans towards illegal immigration, particularly female workers (Weeks 2005: 123, Mosneaga 
2003). It is estimated that about 20,000 to 30,000 women from Moldova were or are involved in forced or voluntary sex migration and trafficking (Mosneaga 2003).

There are different sources for the evaluation of labour migration in Moldova. For example, several surveys (Mosneaga 2007a; IOM 2005; UNDP 2006; World Bank 2005) in Moldova have estimated the number of people emigrating (legally or illegally) and working abroad to be between 200,000 to 800,000 , which is 6 to2 4 per cent of the total population or 10 to 40 per cent of the working-age population (around 2 million). The majority of migrants (about 6o per cent) go to Russia, whilst about 30 per cent go to the EU, especially to Italy, Portugal and Greece (IOM 2005). Romania and Ukraine are of little interest to Moldovan labour migrants because they have relatively low living standards and incomes. According to estimates by various experts, the dispersal of Moldovan migrants across destination countries is as follows: Russia 240,000 to 270,000 ; Italy up to 130,000 ; Portugal up to 80,000; Greece, 50,000; the Czech Republic, 40,000; Spain, 20,000; Israel, 20,000-25,000; Ukraine, 12,000; Germany, 10,000-15,000; Cyprus, 5,000-7,000; and Romania, 5,000 (Mosneaga 2003). However, this is subject to change; notably the flow to the EU has been increasing in recent years (Mosneaga 2008). The factor that makes migration outflow from Moldova particularly distinct from other countries is its sustained nature throughout the period since independence.

The consequences of emigration for Moldova's economy and society are complex. Remittances sent by - often irregular - migrants to Moldova constitute 30.8 per cent of Moldova's GDP (as shown in table 8.1) and it is estimated that migration has reduced poverty by up to 25 per cent. Remittances have been a major aid to the economy of the country though they contribute very little to its growth, because they are mainly used for everyday consumption. For example, several surveys suggested that 20 per cent of the money went to repay debts, 44 per cent on food, clothes and so on, 11 per cent on health, education or household equipment, 19 per cent on household improvements or family festivals such as weddings, and less than 1 per cent on land purchase or business investment (IOM 2005). Other negative consequences are related to the significant brain-drain resulting from out-migration: for instance, from 2000 to 2004, Moldova lost 36,000 doctors and 28,00o teachers due to emigration to other countries (Mosneaga 2007a). Out-migration also negatively impacts the family structure; most significantly, at least 100,000 children in Moldova live without their parents because they work abroad. This has in fact become a national problem. 
Table 8.1 Remittances of Moldovan labour migrants in 1995-2008 (million US dollars)

\begin{tabular}{lrrrrrrrrrrr}
\hline & 1998 & 1999 & 2000 & 2001 & 2002 & 2003 & 2004 & 2005 & 2006 & 2007 & 2008 \\
\hline US \$ & 121.0 & 109.8 & 159.0 & 223.0 & 268.0 & 461 & 701 & 915 & 1.182 & 1.286 & 1.612 \\
\% GDP & 7.1 & 9.3 & 12.3 & 15.1 & 16.5 & 23.5 & 27.1 & 31.7 & 38.2 & 36.2 & 30.8 \\
\hline
\end{tabular}

Source: National Bank of Moldova (2009)

\subsection{Theoretical and methodological approach}

This chapter draws on social capital theories (developed by Glenn Loury in 1977 and further elaborated by Pierre Bourdieu and James Coleman). These theories were applied to the study of migrant networks as a form of social capital by Douglas Massey to explain how people seek to migrate abroad using the ties of people who had already migrated. In the context of Massey's research, these ties 'are transformed into a resource that can be used to gain access to foreign employment and all that it brings' (Massey et al. 1998: 43). The research presented here applies these theories to explain the observed migration patterns, notably to analyse the development of the stages of migration and the trajectory of transit migration. In particular, our research confirms the following:

Because of the nature of kinship and friendship structure each new migrant creates a set of people with social ties to the destination area. Migrants are inevitably linked to non-migrants to gain access to employment and assistance at the point of destination (Massey et al. 1998: 43).

This chapter mostly concentrates on the transit migration of Moldovans and other citizens on their way to the EU and does not focus on migration to Russia. It is based on (a) more than 200 in-depth interviews with Moldovan economic migrants in various EU countries, including Italy, France and Portugal, (b) a survey conducted in Moldova in 2006-2007 and (c) interviews with officers of the diplomatic, migration and border guard authorities of Ukraine (February 2008), Slovakia (December 2007) and the Republic of Moldova (October 2008). 


\subsection{Government efforts on migration management}

The Moldovan government approaches migration within the context of social policy. The authorities have recently approved and are implementing new approaches to try to reduce labour migration through the introduction of poverty reduction measures and by improving the employment situation. Therefore, programmes such as the 'Modernisation of the Country for the Sake of the People's Well-Being' that ran between 2005 and 2009 are aimed at improving the economic situation of the country. The Moldovan state is also implementing the 'Moldovan Countryside Programme', a series of measures aimed at the revival of the rural regions. The main policy vehicle for the revival of Moldova's economy is to be based on the growth of direct investment in a programme called 'Revival of the Economy is Revival of the Country'. This programme proposes to include the remittances from Moldovan citizens working abroad as primary sources of direct investment in the national economy. Under the programme, these remittances are to be stimulated and channelled towards investment in local projects, with the aim of developing Moldovan settlements and communities from which economic migrants originate, including their birthplace and the communities that they left behind. In addition, since 2006, engagement with the 'old' and 'new' Moldovan communities and diasporas abroad has been intensified; for example, the 'Programme to support the Moldovan Community Abroad' was introduced (Schwarts 2007; Mosneaga \& Rusu 2008).

The authorities also try to prevent unregulated economic migration both into and out of the country. Moldova has a relatively well-developed legal base for migration management. It has adopted the concept of migration policy and laws 'on migration', 'on citizenship', 'on entry and stay in the Republic of Moldova', 'on the legal status of foreign citizens and persons without citizenship' and 'on the status of refugee'. The law 'on labour migration' was passed in March 2008 and introduced control over the activity of agencies engaged in the employment of Moldovans abroad. Such companies are now required to submit quarterly reports to the National Bureau of Statistics and to the Agency for Employment of Population indicating the number of migrants who have left the republic, their destination and the duration spent abroad. Parents who are going to go to work abroad are required to provide evidence to the agencies of their provision for care of their children. Moldova has established close cooperation with the EU in the sphere of migration management and control. Most measures are implemented within the frame of the Eastern Partnership (EaP) part of the 
European Neighbourhood Policy (ENP). Initially, the main policies were in the field of border controls, such as the EU Border Assistance Mission (EUBAM) on the borders of Transdnestria. In 2007, an integrated EU visa centre was opened to simplify visa applications for travel and migration to the EU, with the aim of facilitating legal migration. In another step, a readmission agreement was signed and upon implementation, the visa regime was further liberalized in January 2008. Finally, in June 2008, the Republic of Moldova was selected by the EU as one of the countries with which the EU pilots mobility partnerships in order to facilitate circular migration. Other new programmes focus on Moldova's capacity to tackle immigration and the inflow of refugees, notably through cooperation with third countries in the sphere of asylum and migration, and agreements on visa regimes and facilitation of readmission were improved.

The Moldovan government is also taking steps to eliminate human trafficking. Laws have been adopted 'on the prevention and elimination of trafficking in human beings' and national plans for the prevention of trafficking in human beings have been developed. These have resulted in the creation of a department for combating organised crime, mainly related to trafficking in human beings, which was established within the Ministry of the Interior. In 1998, an article (Article 105) was accordingly added to the Penal Code. In July 2001, further modifications related to the trafficking of human beings were introduced. Article 113-2, which penalises trafficking in human beings, was modified so that this criminal activity can now result in long prison terms for the perpetrators. Finally, in August 2005, a new national plan to fight against trafficking in human beings was adopted.

\subsection{Irregular (transit) migration from Moldova}

It is difficult to give an unequivocal, precise number for Moldovan migrants involved in irregular transit migration processes. The official data from Western European countries indicate that there are 100-150,000 regularised Moldovan citizens in the region (Baldwin-Edwards \& Kraler 2009). In particular, no fewer than 100,000 Moldovans were regularised in the early 21st century in Italy, Greece and Portugal alone. However, there are also increasing opportunities for Moldovan citizens to become irregular citizens: for example, companies are increasingly looking for students through 'work and travel' programmes. A considerable proportion of the students who leave Moldova on these programmes do not return home. Instead, they prolong their stay abroad and become engaged in irregular employment. 
Recently there have been attempts to plug the gap in the database on issues of irregular transit migration from countries in the southern EU neighbourhood region. In this respect the Söderköping Process, Swedish-funded 'enhanced cross-border co-operation between the Western Newly Independent States (NIS) and the EU' provides some information on peripheral EU countries located on the EU's eastern border. The information resulting from the Söderköping Process reveals that Moldovan citizens make up a significant a share of the violators of border and residency regimes. Over a period of two and a half years (2004 to May 2006), Moldova was second on the list of violators among the EU's neighbouring states (Pribytkova \& Gromovs 2007). Of the 46,220 migrants arrested in the territories of Estonia, Latvia, Lithuania, Poland, Slovakia, Hungary, and Romania, 4,293 were Moldovan citizens, or almost 10 per cent. Of the 32,203 migrants detained at the borders of these countries, presumably for irregular entry, 4,770 were citizens of Moldova (14.8 per cent of the total) (Pribytkova \& Gromovs 2007). The ICMPD yearbook (2010) information about those apprehended in 2007-2008 at the Ukrainian, Hungarian and Romanian borders reveals that 5,621 people in 2007 and 5,138 in 2008 were Moldovan citizens.

\section{Destination countries, determinants and migrants' choices}

The selection of a destination country within the EU is determined by various factors such as the level of wages, the host country's migration and reception policy, population attitudes, language and even similar climatic conditions. From the Moldovan migrants' perspective, the Mediterranean countries are particularly well suited. Nevertheless, by the end of 2010, Moldovan diasporas had appeared in many other EU and non-EU countries too. Sociological surveys demonstrate that the largest proportion of Moldovan economic migrants is currently found in Russia, where 6o per cent of migrants are concentrated, Italy (20 per cent) and Portugal (5 per cent); but small numbers are also found Spain, Turkey, Greece, France, the UK, Ireland, Romania and Ukraine. Around three quarters of all Moldovan economic migrants are concentrated in ten cities: Moscow, Rome, Saint Petersburg, Istanbul, Odessa and some other Russian oil industry cities (Lucke, Mahmoud \& Pinger 2007). These statistics indicate a trend towards the concentration of migrants in major urban centres. The destination countries can be characterised according to the professions and gender of the migrants that they attract. Russia, Ukraine, Spain, Portugal and the Czech Republic attract mainly male migrants, who are employed primarily in the construction industry. In Italy, Turkey, Greece and Cyprus, Moldovans find employment in the service sector and this attracts mostly female migrants. 
Thus, countries can almost be distinguished as 'male' and 'female' countries of destination (Mosneaga 2007a).

The availability of social and migration networks also plays an important role in migrants' choices. It can be assumed that the role of occasional or accidental choice in the selection of a country of destination has decreased, not least because the journey is expensive and the migrants' time spent in the EU for economic purposes is usually not less than six months. Previous research suggests that cases of unprepared migration with the random choice of a destination country have diminished (Mosneaga \& Rusu 2008). Indeed, networks of Moldovan diasporas have already been well established and developed. These prompt prospective migrants to choose a country where friends or relatives already live. Indeed, as argued elsewhere, 'ethnic corridors' of Moldovans have emerged, running through various countries, facilitating transit migration (Mosneaga 2008).

According to research findings, only a few migrants travel without making preliminary arrangements for their trip (Mosneaga 2007a). Before leaving for a foreign country they seek to establish contacts with relatives, acquaintances, friends and natives of their home village who are working abroad, with a view to collecting information about the labour market in the potential destination country and to actually find a job prior to departure (table 8.2). Research findings (see, e.g., Mosneaga 2007a; IOM 2005; World Bank 2006) confirm that nowadays virtually no one goes abroad on a hitor-miss basis. Frequently, migrants make efforts to arrange a visa, legal residence and employment abroad on the basis of a legal labour contract. There is also an informal labour market where economic migrants often engage their friends and neighbours in the recruitment of migrants for jobs. Relatives and friends provide great help in the search for a labour contract signed by an employer in the country of reception. These people negotiate the details of the labour contract for their relative (or a friend or fellow countryman) with their employer in the country of reception and residence. Usually an employer who has a positive opinion of one migrant applicant agrees to make a labour contract with another potential labourer from Moldova. A labour migrant who already works for this employer acts as a guarantor for the professionalism, diligence and law-abiding character of the potential labour migrant. The new migrant will pay his or her friend for the invitation and employment.

Making the necessary arrangements for migration costs a significant amount of money. Interviews conducted by the author with migrants suggest that, on average, the fee taken by a facilitator is approximately $€_{100}$ to $€_{500}$. The total cost of a labour contract for a potential migrant 
depends on the number of intermediaries between an employer and his or her future employee. Each of these intermediates takes a commission fee and, therefore, the relatives, fellow-countrymen and friends of a potential migrant get some money in return for their efforts to find work for a new migrant from Moldova. The cost of procuring a labour contract for a potential migrant is about $€ 2,000$, which may exceed the real cost of the labour contract ten times.

Every step of the preparation of a migrant's journey, as table 8.2 demonstrates, involves at least one migrant-supporting individual or institution, though the involvement of these individuals or institutions differs. If the person undertakes a legal journey, they usually reach their destination easily, but in the case of an illegal journey, the number of steps increases and consequently, the institutional involvement also increases depending on financial opportunities and the specific institutions involved. In this context, the weakness of the Moldovan state creates problems for the control and regulation of migration flows that use the institutional forms of organisation. Therefore, flourishing corruption in governmental structures supports a black market in migration services.

\section{The journey to the EU: Transit migration and border crossing strategies}

The majority of Moldovan economic migrants seek and enter their destination legally. There is evidence that significant numbers of migrants seek to use the opportunity of dual citizenship through acquiring citizenship status in neighbouring EU countries. They are particularly interested in Romanian and Bulgarian citizenship because both countries joined the EU in January 2007. According to expert calculations (Mosneaga \& Rusu 2008) and statements of the Romanian authorities, no fewer than half a million Moldovan citizens have submitted all the required documents and are waiting to obtain Romanian citizenship. Similarly, about 50,000-70,000 Moldovans have put in a claim for Bulgarian citizenship. This is almost a fifth of the total population of Moldova. By 2009, at least 130,000-150,000 Moldovans already held citizenship of an EU country.

If a potential migrant does not have the opportunity of EU citizenship, he/ she is required to have a visa for legal travel to an EU country, though such a visa does not guarantee that all migration is regular. Visas can be obtained through tourist or travel agencies. For the visa application they must state the reason for their visit (employment or tourism) and they must be able to provide evidence in the form of an employment contract or invitation from friends or relatives. Although there are considerable Moldovan diasporas in Western Europe, in many countries these are often not well established. 
Therefore, many Moldovans living abroad lack the legally required resources and indeed even the legal status to invite friends or relatives. Alternatively, a potential migrant could try and find locals to agree to provide such invitations, if they know any well enough. But sometimes procuring an invitation becomes problematic due to lack of money or networks. A dilemma may therefore arise, leaving prospective migrants with no option other than to try to reach their destination countries irregularly, thus violating the rules for crossing state borders. Where a migrant does have a visa, he or she uses it to reach the destination country legally but, often, after the short-term visa expires, the migrants stay in the destination country illegally and take up irregular employment. It should be noted that opportunities for legal entry to EU countries for employment purposes are very limited and demand for tourist visas is increasing. Tourist and travel agencies of the Republic of Moldova and Ukraine often use their licences to help people migrate for employment. One migrant interviewed commented 'we left Moldova with the help of a tourist company, which instantly found jobs for us for a fee of $\$ 400$ dollars a head. All in all, this trip cost me $\$ 2,000$ ' (Jonah, age 50). ${ }^{3}$ But in order to counteract the irregular activity of pseudo-tourist companies, the Moldovan authorities have tightened controls over them and now have the power to withdraw licences.

If it proves impossible to obtain a visa through legal channels, Moldovan migrants may also use forged documents, or authentic documents that belong to other people, to enter non-EU and EU countries at regular border crossing points. The documents may be in the person's real name but involve faked visas and passports. The following quote illustrates how this strategy was used for a migrant's journey to Ireland.

I had a girlfriend at that time ... This girl found a channel that we could use to reach the country of destination. I went together with her sister. Two faked passports were produced for each of us. In addition, we had our own legal passports with a tourist visa. We travelled from Kiev to Riga ... From Riga we came to Ireland using the other passport. We arrived in Ireland and lived with my girlfriend ... Our visas expired a week after we arrived in Ireland but we stayed on (Julia, age 32).

Alternatively, clandestine strategies are frequently used to cross borders. Migrants who seek to cross a state border illegally may hide in trucks carrying timber, wool, cigarettes, toys, metalware, nails and carpets. Such 
violations of the state border are most often discovered on the section of border between Moldova and Romania. Alternatively, they walk across state borders. The representatives of Ukrainian, Moldovan and Slovakian border guard services and migration structures have identified the forested, mountainous section of the Ukrainian-Slovakian border (a stretch of about $100 \mathrm{~km}$ ) as the most attractive section of the border for irregular migrants. The Moldovan media often present news on such cases on the Romanian, Slovakian, Italian, Slovenian, and other states' borders. The following interview with a labour migrant is quite eloquent in this respect.

I found my way to Italy after illegally crossing the mountain border. Earlier, I made an attempt to enter Italy legally, on the basis of a tourist visa. But I was sent back at the border. My visa was fake and my name was put in the computer. The money I spent for the visa was wasted. I was not admitted to Italy. And the debt remained ... I decided not to spend money for a visa anymore and to cross the border illegally. I shall not tell you where and how I crossed the border. It is my secret. I'll tell you only that I went through three pairs of shoes before I reached Italy (Peter, age 25).

Table 8.2 Migrants' preparation steps for a journey to the EU

\section{Information-gathering to search for potential work}

2. Search for legal ways to cross the border and enter the EU/Schengen zone

3. Preparation of documents

\section{Journey}

Regular

1. Legal border crossing based on available permits for legal residence and work activities in the EU countries

\section{Legal crossing of borders with tourist} visas

3. Pretended legal crossing of borders with the help of passports issued in other countries for other persons
Irregular

1. Clandestine crossing of the 'green border'

2. Clandestine crossing of the border hidden in a motor vehicle

3. Irregular crossing of the border at legal entry points using fake (forged) documents or authentic documents that belong to other persons

4. Crossing of the border with the help of an intermediary service or human traffickers

\section{Arriving and settling}




\subsection{The services for illegal migration and trafficking}

Migrants cannot cross the state border irregularly without intermediaries who act in the borderland territories of different countries and provide transit channels. For example, when a visa regime between Romania and Moldova was introduced in 2007, the introduction of an online procedure to obtain a Romanian visa in the consulate office of Romania in Chisinau caused a proliferation of so-called 'well-wishers'. These are people who for a fee of $€ 2,000$ to $€ 2,500$ offer counterfeited Romanian documents or identity cards/passports of other persons. These people can usually be found around the Romanian consulate offices where they offer their services, often from vans (Pop 2007).

For the clandestine crossing of green borders, migrants need guides who are familiar with the local conditions, topography and the situation on the border, including border guards' locations and routines. Sometimes migrants' fellow-countrymen act as guides; for a fee they provide services for the organisation, implementation and travel of irregular transit migrants.

I am from a small town ... There is a company in our town. And this company provides tourist services ... We paid an enormous sum, $€_{3,000}$ per person ... We reached Italy as tourists. Then we left the bus and were met by a man at a station. He was a Moldovan who had to take us through the mountains to Switzerland ... We reached the border which ran along a mountain ridge there. Our guide brought us to the pass and said: 'Go along this path and descend to the valley. It will be Switzerland. There is a village below and you will find a bar there. Go to the bar, our man will wait for you there' ... We came to the village and found the bar. There was only a bartender there. We asked him whether he was the person we were looking for. He cast a strange look at us, ... then he left the bar, within a few minutes he came back and a bit later the police arrested us in that bar as irregular migrants. We were permitted to make a call from a mobile phone and we called this company which had organised taking us to Switzerland ... We told them that they did not fulfil their obligations. If they deport us we'll come back, burn their office down and kill them ... I do not know what that man said to the police ... but we were released (Feodor, age 43).

The structures - social networks and criminal organisations - that facilitate the irregular (transit) migration process continue to play a role at the point of arrival. It was found that relatives and friends provide great help in 
the search for employment. An excerpt from an interview illustrates the situation:

There is a black market in Rome where Moldovans deal in jobs. Two jobs were offered to me and my partner. After some discussion and bargaining we paid a certain amount for our jobs. But for our money we were sure that we really had jobs (Igor, age 40).

The groups can either be nationally and ethnically homogenous, or mixed and composed of citizens of different states. State sources claim that this process is controlled by international criminal groups that have developed networks in many countries. Indeed, law enforcement bodies detect many organisations and people engaged in the technical support of this form of migration. Companies that produced forged documents were also identified in Moldova. The director of the Centre to Combat Trafficking in Human Beings noted the following:

In 2007, officers of the centre initiated 516 criminal cases connected with irregular migration, trafficking in humans ... In the same year, the officers of the Centre detected 40 channels for channelling Moldovan citizens abroad, to EU countries ... In 2008, an international criminal grouping was detected and recorded. A mini-printing office equipped with the most advanced accessories was found in the apartment rented by the criminals. More than 100 forged documents including 21 identity cards of Romanian citizens and ${ }_{17}$ Romanian driving licenses, 43 faked Moldovan passports, nine faked passports of the Czech Republic, 13 permits for staying in Italy, several counterfeited passports of citizens of Romania, Turkey, Latvia and Belarus were found and confiscated (Pop 2008).

Criminal activities facilitating irregular transit migration have often been found to be supported or shielded by the governmental official institutions that are supposed to fight against these processes.

I am unable to understand why the Republic of Moldova cannot acquire special devices capable of distinguishing whether a migrant presents authentic or forged documents and installing these devices in the airport and at border crossing checkpoints. These devices can determine whether passports, permits for staying in EU countries and other documents are authentic and true or not. I do not want to draw conclusions even though they are obvious: someone considers that availability of such devices is 
detrimental to his interests (Conversation with Romanian Consul in the Republic of Moldova, April 2009).

Notably, cases of human trafficking were reported which were organised under the protection of law enforcement officers in Moldova. For example, in 2006, a criminal group headed by Ion Bejan, director of the Ministry of Interior's Department for Fighting Human Trafficking (DFHF), was detected and broken up. Police officers of different positions and high-ranking officials were involved in this criminal organisation and directly involved in the process of irregular transit migration and its support (Pop 2007; also see Radu 2007). Such practices are labelled as 'roofing', meaning that senior officials provide a secure 'roof' under which such activities can unfold.

The US Department of State's reports 'On Trafficking in Humans, 2007' and 'On Trafficking in Humans, 2008' reached similar conclusions. It accused the Moldovan authorities, notably senior representatives of the Moldovan Ministry of Interior who were supposed to fight against irregular migration of passivity and double standards. However, nothing is known with respect to the investigation of senior police officers who were suspected of providing coverage or a so-called 'roof' for facilitators of irregular migration. After that critique the Moldovan authorities were forced to undertake some organisational measures with respect to the DFHF officers and installed the devices required for identification of documents' authenticity in October 2009.

\subsection{Main routes for transit migration from Moldova to the EU}

Moldovan migrants, due to their poverty and lack of appropriate documentation, usually travel overland. First, they travel from Moldova to a neighbouring non-EU or EU countryhood. Migration from Moldova to the European Union involves various routes: the main ones run through Ukraine and Romania, though there are also alternatives available through Turkey. Once in the EU, various member states may have to be crossed until the destination country is reached. Accordingly, routes are often complex and journeys long, as the following interview illustrates.

We left for Portugal with some friends. We departed legally as tourists. We reached Italy by bus. We knew nobody in Italy and did not speak Italian. We disembarked from the bus and wanted to get to the railway station. Luckily, one of us could speak a bit of English. He asked people 
and finally we got to the station. We bought railway tickets and went to France. Then we went to Spain. And finally, we found ourselves in Portugal (Michael, age 34).

Citizens of Moldova, like those of other CIS republics, are not required to have a visa to enter Ukraine and thus rarely enter the country irregularly. Usually, Moldovans enter Ukraine on the south-eastern border of Moldova, which runs across the Odessa region of Ukraine, or the north-western borders in the Chernovtsy and Khmelnitsky regions, mostly using railways or motorways. First, they take the bus and train to Odessa, from there they can reach Turkey by sea. Until recently, the route to Turkey required visas, which could be obtained with the help of tourist and travel agencies in Moldova or Ukraine. In the meantime, Turkey has changed its visa regulations for many countries and three-month visas are now issued on the border. Alternatively, from Odessa migrants take the bus or train to the western or north-western regions of Ukraine where it borders Slovakia, Hungary, Poland and Belarus. From there they enter Slovakia, Hungary and Poland through the regular border crossing points using tourist visas, faked documents or original documents of other persons; alternatively, they make a clandestine crossing of the 'green' border (see Molodikova, this volume). Usually these migrants intend to move on to one of the 'old' EU countries. The final option for onward travel from Odessa is to take a bus or train to Kiev or another Ukrainian city that has a port or airports with connections to Austria, Cyprus, Israel and Turkey or the states of the Middle East. This last route is often used for purposes of trafficking women for sexual labour migration (Malarek 2008).

The other main route runs through Romania. Before 2007, Moldovans could enter Romania legally and visa-free on the basis that they were visiting relatives or were tourists. From Romania, Moldovan migrants may try to cross over to the 'old' EU countries either using visas obtained at EU countries' embassies in Bucharest, at regular border crossings but with faked documents, by hiding in transportation vehicles, or irregularly through the 'green' border. When Romania joined the EU in January 2007, a new visa regime was introduced for citizens of Moldova. This led to modifications in irregular migration tactics. The majority of Moldovans still enter Romania legally, with visas obtained from some agencies and issued by Romania's embassies and consulate offices in Moldova (in Chisinau) and Ukraine (in Kiev, Odessa or Chernovtsy). Some try to enter Romania illegally and move to other EU countries (see Futo 2008). Usually, Moldovan migrants enter Romania through the Moldova-Romania section of the state border on the 
bus and train route to Lasy/Galati/Bucharest or on the bus and train route from Bucharest to Arad/Oradea/Timisoara.

Data from interviews suggest that after a short one-to-two day stay in some Romanian cities near the eastern borders, migrants obtain faked passports or establish contact with guides. Afterwards, they move on to the western, south-western or southern borders of Romania. Many of these routes are associated not only with labour migration, but also with human trafficking for sexual exploitation. The routes were particularly popular in the late 1990 and the early 200os. Analysis of border violations committed by Moldovan citizens at Romanian border crossings suggests that the number of Moldovan citizens who try to enter Romania or leave it for other EU countries, by hiding in motor vehicles, is rising. Simultaneously, the number of Romanian border violators who seek to leave Romania for the old EU countries with the help of faked documents has also increased.

An alternative migration route is air travel from Moldova to Turkey (Istanbul or Antalya). However, this route generally forms part of a longer journey, either to the Middle East or to the countries of the Southern Mediterranean (Morocco, Tunisia, etc.), from where Moldovan economic migrants may seek entry to EU states. It could be expected that the opening of the new Danube passenger terminal in Giurgiulesti (Republic of Moldova) and the introduction of regular sea-passenger services to Bulgaria and Turkey will lead to the emergence of legal as well as irregular labour migration via these countries too.

Finally, Moldovans also cross various EU countries until they reach their destination.

We went to Poland by bus ... in Poland we waited until night, swam across the Oder river and reached Germany ... and went further across Germany. We crossed a wood, came to the railway line, walked along it to the nearest station where we bought tickets to the West and left for France (Nicholas, age 27).

Two criteria, earnings and attitudes of the police, are given as reasons for migrating on to other countries instead of staying in the first EU country of arrival: 'I went to France to earn money. In this respect France is better than Germany or Austria. At least the French police are more lenient and less severe' (Nicholas, age 35).

It is difficult to identify the principal or preferred routes of Moldovan irregular migrants within the EU. As already noted, when people choose routes they evaluate various options with respect to the geographical and 
political conditions, the migration policy pursued by EU states, and the availability of social capital in countries of reception and transit. Due to the effects of situational factors related to the activity of smuggling and trafficking networks, these routes change. From the interviews, various routes can be identified:

$$
\begin{aligned}
\text { Moldova - Ukraine }- & \text { Slovakia - the Czech Republic - Germany - } \\
& \text { France - Spain - Portugal; } \\
- & \text { Slovakia - Austria - Italy - France - Spain - } \\
& \text { Portugal; } \\
- & \text { Poland - Germany - Belgium - France - UK; } \\
- & \text { Latvia - Ireland; } \\
\text { Moldova - Romania - } & \text { Hungary - Austria - Italy; } \\
- & \text { Bulgaria - Macedonia - Croatia - Slovenia - } \\
& \text { Italy - Switzerland. } \\
\text { Moldova - Turkey }- & \text { Middle East or Southern Mediterranean. }
\end{aligned}
$$

More generally, three main passages seem to be used: the eastern passage from Moldova to Romania, the northern passage from Moldova through Ukraine and then to Hungary, Slovakia and Poland; or the southern passage from Moldova through Bulgaria, Serbia or the sea and even Turkey.

\subsection{Return transit migration to Moldova}

Return to Moldova can be as complicated as the actual out-migration. It can be assumed that irregular migrants are unable or unwilling to stay permanently in the host countries. This could be because of the increasing disadvantages that come with a lack of status. Alternatively, they may wish to visit their relatives back home and for this reason need to travel back to Moldova. If they wish to travel back home cheaply, they need to leave as they came: overland and, for instance, by bus, which will again take them across the borders of several countries. This increases the risks of being detected as 'illegal immigrants' on the outward-journey and may even include the risk of detention and deportation. In both cases, the irregular migrant's personal data will be entered into the EU database, notably Eurodac and the Schengen Information System (SIS). As a result, such migrants will often be banned from re-entry to the EU for a significant period of time. 
It is suggested that Moldovan irregular migrants wishing to return to Moldova know about different practices in diverse EU countries and respond accordingly to these opportunities.

They seek to submit their application to the Moldovan consulates abroad under the pretext of 'loss of national passports' and to get 'clean' passports that allow them to go to the homeland unobstructed. It should be noted that such migrants who have got clean passports in the Consulate General in Frankfurt, Germany, do not leave for Moldova from Frankfurt but go to France and take off for Chisinau from Paris. The reason for such behaviour is that the German border guard service puts information on such migrants (those who lost their original passports) into a database while their French counterparts are satisfied with a person's departure from France and do not put the information into the European database (conversation with Consul General of Republic of Moldova in Frankfurt, Germany, February 2009).

Irregular migrants who were apprehended, deported and served with a re-entry ban also resort to various tricks to address this issue. Some change their family name and adopt their mothers' or their wives' family names and when they enter the EU with their new family name they circumvent the re-entry ban. Others forge or counterfeit their passports or migrate with documents that belong to other people.

\subsection{Irregular transit migration via the Republic of Moldova}

Transit or onward migration through Moldova is a new phenomenon in immigration processes and has only been observed recently. Such flows include people who arrived in Moldova and either do not want to return to their homelands (e.g., students) or who cannot return (refugees), as well as irregular transit migrants who take advantage of the relatively porous CIS borders between Ukraine and Moldova, and try to get to Western European countries. However, if this route is chosen, the irregular transit migrant has to cross one more border into Moldova, then from there to Ukraine and finally to an EU country, instead of going directly to Ukraine and then on to the EU. This involves extra risks and additional financial and organisational costs related to the search for organisers/carriers. Therefore this route seems less popular. 
Transit migrants in Moldova are predominantly natives of Central Asian and South-East Asian countries who first travel through Russia and Ukraine. The main countries of origin are Afghanistan, Pakistan, Iraq, Senegal, Mali and also other countries. These migrants try to find new routes to enter the EU. Other cases of irregular transit migration were exposed in the mid-199os, when citizens of Iran crossed the Romanian-Moldovan border illegally and entered into Moldova with the purpose of moving further to the east on their way back to Iran. Despite the fact that this route is less popular than other migration routes, there are cases emerging of migrants being caught using Moldovan as a transit country. For instance, in April 2008, Moldovan border guards discovered seven Afghans who had been trying to get to Italy. At the point of their arrest they had already been travelling for two years. Another instance involves a group of Malians travelling via Odessa and Transdnestria who aimed to get to the EU by sea, but found themselves abandoned by their smugglers in Moldova. According to information released by the Moldova Security Service in cooperation with other state bodies, in 2008, approximately 18,00o irregular migrants from Turkey, India, Pakistan, Sri-Lanka, Bangladesh and other countries were arrested (see Nezavisimaya Moldova, 3 October 2008). ${ }^{4}$ More than 250 foreign citizens who are suspected organisers of irregular migration and more than 300 of their suspected Moldovan accomplices have been detected. Of these, 98 were subsequently tried by the courts; it is claimed that eight criminal groupings engaged in this illegal activity have been smashed.

\subsection{Conclusion}

Moldova is a small and divided country with a labour market of limited capacity that is unable to provide sufficient jobs and salaries to support the entire population. As a consequence, Moldovans move abroad in significant numbers to seek livelihoods there. But Moldova is sandwiched between Romania and Ukraine, which have also experienced the hardship of transition and poverty and are both major sending countries of labour migrants. Hence, Moldova's immediate neighbours lack the capacity to absorb labour migrants. Thus, Moldovans who choose to move abroad for work have no other option but to cross neighbouring and various other countries in order to reach their destination. Over the past 20 years, almost the entire economically active population of Moldova has been involved 
in various forms of migration. Due to the character of the economic and political situation, it can be assumed that the outflow of labour migrants is a phenomenon that will persist. The remittances sent back to the country by migrants working abroad are used for basic household consumption and to support the population in their everyday life. Thus they contribute little to boosting the economy and future development of country.

After the accession of Romania to the EU, Moldova has become an adjacent country just outside the EU. As a result, it seems to be emerging as yet another transit territory for migrants from more distant countries on their way to the EU. The illegal transit migration through Moldova and from Moldova relies heavily on well-developed migration networks of relatives, friends and intermediaries. The Moldovan diasporas in all EU countries actively facilitate the migration processes and function as 'ethnic corridors' and points of reference in the destination countries. In addition, criminal structures and corrupt officials provide travel services to support entry to EU countries. Finally, irregular migration, transit migration and smuggling are connected with human trafficking, and the discourses are intertwined and confused.

The Moldovan government is making enormous efforts to develop its migration management. Nevertheless, the scale of migration outflow is so high that in spite of all these measures it is barely possible to organise efficient controls. Effective combating of unregulated labour migration is a complex and extensive process, which combines law enforcement and economic measures. These measures require multi-faceted cooperation between international and national structures, and between state bodies and non-governmental organisations. But in order to address and prevent irregular migration from Moldova, living conditions within Moldova would need to be significantly improved. Without the assistance of the EU, this goal will be very difficult to reach.

\section{References}

Baldwin-Edwards, M. \& A. Kraler (eds) (2009), REGINE: Regularisations in Europe. Amsterdam: Pallas Publications.

Dolghih, E. (2003), 'Trudovie migranti iz Moldovi v Rossii (po dannim sotiocogiceskih oprosov v poezdah Kishinev-Moskva-Kishinev)', in Trudovaia Migratsia IZascita Prav Gastarbaiterov: Praktika Postkommunisticeskih Stran. Kishinev: USM, 44-54.

Dressler, W. (2004), 'Trust in building multicultural democratic societies: Estonia, Moldova and Kazakhstan', in I. Marková (ed.), Trust and Democratic Transition in Post-Communist Europe. Oxford: Oxford University Press, 109-132. 
Düvell, F. (2006), 'Crossing the Fringes of Europe: Transit Migration in the EU's Neighbourhood'. Working Paper No. 33. Oxford: University of Oxford, COMPAS.

Futo, P. (2008), Yearbook on Illegal Migration, Human Smuggling and Trafficking in Central and Eastern Europe in 2007. Vienna: ICMPD.

Futo P. (2010), Yearbook on Illegal Migration, Human Smuggling and Trafficking in Central and Eastern Europe. Vienna: ICMPD.

ILO (2005), Forced Labour Outcomes of Migration from Moldova: Rapid Assessment. Geneva, ILO.

IOM (2005), Identification and Protection Schemes for Victims of Trafficking in Persons in Europe: Tools and Best Practices. December 2005. Brussels: IOM.

International Monetary Fund (2005), Republic of Moldova: Selected Issues. Washington, DC: IMF.

Lucke, M., T.O. Mahmoud \& P. Pinger (2007), Patterns and Trends of Migration and Remittances in Moldova. Chisinau: SIDA, IOM.

Laur, E. (2003), Moldova: Mothers' Employment and Children's Poverty. Florence: Innocenti Research Centre.

Marková, I. (2004), 'Introduction: Trust/risk and trust/fear', in I. Marková (ed.), Trust and Democratic Transition in Post-Communist Europe. Oxford: Oxford University Press, 1-24.

Malarek, V. (2008), Prodautsia Natashi: Novaia Globalnaia Torgovlia Seksom [Natashas'for Sale: New Global Sex Industry]. Moscow: Kolibri.

Massey, D.S., Joaquín Arango, Graeme Hugo, Ali Kouaouci, Adela Pellegrino \& J. Edward Taylor (1998), Worlds in Motion:International Migration at the End of the Millennium. Oxford: Oxford University Press.

Milanovic, B. (1998), Income Equality and Poverty during the Transition: A Survey of the Evidence. Washington, DC: World Bank.

Malynovska, O., V. Mosneaga \& L. Shahotko (2007), Labour Migration Assessment for the WNIS Region. Kiev: IOM.

Mosneaga, V. (2003), Labour Migration and Protection of Gastarbeiters' Rights: Practise of Post Communism Countries. Chisinau: State University.

Mosneaga, V. (2007a), Republic of Moldova: Trends and regulation of migrations. Labor Migration Assessment for WNIS Region. Kiev: IOM.

Mosneaga, V. (2007b), 'Regulation of labor migration in Republic of Moldova: Main stages and peculiarities', MOLDOSCOPIE (Probleme de analiza politica) 36: 33-48.

Mosneaga, V. (2008), 'Irregular Transitional Migration of Moldovan Citizens: Current Status'. Paper presented at conference '(Irregular) Transit Migration in the European Space: Theory, Politics and Research Methodology', 18-20 April, Istanbul.

Mosneaga, V. \& R. Rusu (2008), 'Formarea diasporei moldovanesti peste hotare: Senta si specificul', MOLDOSCOPIE (Probleme de analiza politica) 40: 91-104. Chisinau: USM.

National Bank of Moldova (2009), Remittances of Moldova Labor Migrants in 1995-2008. Chisinau: NBM, www.bnm.md, retrieved 2 November.

Nezavisimaya, Moldova (2008), 'United database can help secret services', 3 October.

Pop, A. (2008), 'Interview', Nezavisimaya Moldova, 30 January.

Pop, A. (2007), Moldova-Romania: Managing Migration and Combating Trafficking in Human Beings at the EU Eastern Border. Chisinau: IOM.

Pribytkova, I. \& I. Gromovs (2007), Migration Trends 2004-20o6 Soderkoping Process Countries. Kiev: European Commission.

Radu, A. (2007), Moldova:Reporter's Notebook, http://report.globalintegrity.org/Moldova/2007/ notebook, retrieved 16 February 2010.

Schwarts, R. (2007), Exploring the Link between Moldovan Communities Abroad and Moldova. Chisinau: SIDA, IOM. 
Sidorov, D. (2008), 'Trafficking in humans suppressed', Nezavisimaya Moldova, 18 January.

Stratan, A. (2007), 'Moldova has its own position, its own wishes and its own interests', Nezavisimaya Moldova.

Surtees, R. (2005), Raportul Anual Privind Victimele Traficului de Fiinţe Umane în Europa de Sud-Est: Raport pe Tară, Republica Moldova. Geneva: IOM.

Alam A., M. Murthi, R. Yemtsov, E. Murrugarra, N. Dudwick, E. Hamilton \& E. Tiongson (2005), Growth, Poverty, and Inequality: Eastern Europe and the Former Soviet Union. Washington, DC: World Bank, http://publications.worldbank.org/ecommerce/catalog/product?context= drilldown\&item $\% 5$ fid $=4756455$.

Tafi, J. (200o), The Youth of the Republic of Moldova during the Transition Period. Florence: Innocenti Research Centre.

UNDP (2006), Human Development Report 2005. New York: United Nations.

UNICEF (2000), Young People in Changing Societies: The MONEE Project. Florence: Innocenti Research Centre.

UNICEF (2004), Innocenti Social Monitor 2004. Florence: Innocenti Research Centre.

Walker, A. \& C. Walker (1997), Britain Divided: The Growth of Social Exclusion in the 1980s and 199os. London: Child Poverty Action Group.

Weeks, J. (2005), Republic of Moldova: Economic Policies for Youth, Employment and Poverty Reduction. Moldova: UNDP.

World Bank (200o), Making Transition Work for Everyone: Poverty and Inequality in Europe and Central Asia. Washington, DC: World Bank.

World Bank (2005), Moldova: Opportunities for Accelerated Growth. A Country Economic Memorandum for the Republic of Moldova. September 9. Washington, DC: World Bank. 



\title{
9 Transit Migrations in the European Migration Spaces
}

\author{
Politics, Determinants and Dynamics
}

Franck Düvell

There are many Europes: the Europe of the European Union with its 28 member states, the Europe of the Council of Europe with its 47 member states, and some historical ideas of Europe that even included North African Mediterranean regions. Some aspects, such as whether or not Turkey is European or qualifies for membership in the EU, are hotly disputed. Migration within this region and its neighbourhood, the European migration space, is diverse, complex and constantly changing over time. The principal poles of attraction for migration flows are the European Union, though not all its member states, and Russia; other relevant destination countries are Kazakhstan, to some extent Ukraine, Turkey, Israel, Egypt and Libya. Four major migration systems can be identified: the post-Soviet migration system, the Central and Western European migration system, the Turkish/ Middle Eastern migration system and the North African migration system. Each migration system can be distinguished by sub-systems of destination countries as, for example, between Kazakhstan and some of its neighbours; Egypt, Libya and various refugee and labour migrants sending countries; or Turkey and various countries from the Black Sea or Middle Eastern region, such as Moldova and Iran. Migration within this space is not simply east-west or south-north as often suggested in conventional thinking, but far more diverse. Instead, any direction is possible. Indeed, considerable numbers of migrants move south-east, from Turkey to Russia, or from east to east, e.g., Kyrgyzstan to Kazakhstan, or south-south, such as from Mali to Libya. Finally, there are also north-south movements, as of citizens from France to Morocco, or Germany to Turkey, which is often either return, retirement or sunshine but also highly-skilled migration.

In many countries migration in general, either certain directions of flows (immigration, emigration) or certain types of migration (low or highly skilled, irregular or non-European) is considered a sensitive issue. In some countries, as in Ukraine, it is rather large-scale emigration that is considered a problem; also Turkey would prefer to pay attention to its diaspora in Northern Europe than to immigration. But usually it is immigration that raises 
most concerns and is restricted accordingly. There are tensions, however, between individual aspirations, economic demand and political goals, and as a consequence some migration occurs in contravention to political goals and is considered unwanted and irregular (Düvell 2006a). It is assumed that in 2008 there were about 1.9-3.8 million irregular immigrants in the EU (Vogel 2009) and another 4 million or so in Russia (Moscow News 2009). Levels of irregular immigrants have decreased over time across Europe, mostly because various irregular migrant-sending countries (Poland, Lithuania, Romania and others) became EU member states in 2004 and 2007, but also due to various regularisation mechanisms, because of the impact of the economic crisis and due to intensified controls. Nevertheless, the level of irregular migration is still considerable (see Düvell \& Vollmer 2011).

The overwhelming majority of the irregular immigrants in the EU and in Russia arrive legally and enter either visa-free or with a visa but then overstay the expiry date of their visa or take up employment in violation of their visa restrictions (Düvell 2009). Only a minority enters clandestinely; nevertheless, clandestine entry raises the highest concerns. Notably pictures and reports of so-called 'boat-people', migrants and refugees sailing across the Western Atlantic or the Mediterranean Sea to Europe, usually in small and overloaded vessels, prompt fears over 'floods of impoverished people' from the global south. Often, numbers are exaggerated; indeed, some sources like to refer to millions of people who gather on the external borders of the European Union just waiting for a chance to penetrate its borders. Research, as well as apprehension figures at the external borders of the EU (151,000 in 2008, 103,000 in 2009, 73, 000 in 2012), implies (a) that the total number of migrants trying each year to enter clandestinely over land or by boat is rather in the order of 100,000-300,000 and (b) that since 2000 (Turkey) and 2007 (Ukraine) numbers are decreasing (Düvell \& Vollmer 2011). The external borders of the EU, however, are invested with a highly political and symbolic meaning and any violation is considered not only a violation of the law but an infringement of the integrity of the EU and almost perceived as an injury to the body of Europe.

Meanwhile, those migrants who do not qualify for regular entry and stay under the complex and often restrictive regulations of the European Union member states, but who nevertheless aspire to move to Europe, often do so in a (partially) irregular manner. For some, notably if they are from African, Middle Eastern or Asian countries, this means that they have to travel long distances in order to get to Europe. Most such journeys involve various legs or stages with stop-overs of various length, various means of transportation, such as flights, coaches, trains, cars, lorries or 
boats; and often some aspects of the journeys are regular whilst others are irregular or clandestine. These journeys, and the practices those migrants and refugees who lack visas use in order to get to Europe, are widely labelled as 'transit migration'. In the introduction, we critically discussed the epistemological problems and limits of this concept. This chapter compares and contextualises the empirical findings in this book provided by scholars from various countries in the borderlands, on the margins or in the neighbourhood of the European Union. The contributions in this volume focus on the efforts that migrants make to get to the European Union, as well as on the efforts undertaken by national governments to prevent what is usually considered politically undesired. This does not imply that the EU is the only destination; instead, as explained above, Russia, Kazakhstan, Egypt or Turkey and sometimes Tunisia and Morocco are also destination countries and entered by migrants who transited various other countries before arriving there.

\subsection{Contrasting geopolitical structures and migration regimes}

Comparing the migration characteristics of the countries presented in this and other publications (e.g., Molodikova 2009; Düvell 2009) suggests that the countries affected by transit migration in the European migration space can be distinguished by five categories. First, some countries are predominantly receiving countries who also record some transit migration. This is certainly true for Russia, some EU countries such as the Czech Republic, Austria, Greece and Italy, or non-European countries such as Egypt and Libya (until 2010). Other countries studied here seem to be simultaneously sending, receiving and transit countries, as is the case for Ukraine and Turkey. A third category of countries seems to be mostly transit countries and very few migrants do actually intend to stay, as seems to be the case with Morocco, Hungary and Slovakia. A fourth category of countries seems to be predominantly sending countries, notably Moldova, Azerbaijan, Georgia and Armenia; though Azerbaijan, Georgia and even Moldova now face the arrival of small numbers of migrants or refugees. A fifth category is represented by Malta; it is neither a chosen destination nor exactly a transit country, but rather a dead-end road for migrants heading for other EU countries. To some extent this also applies to the Greek Republic of Cyprus.

From a political perspective there are five major regional and sometimes overlapping associations. These are the European Union (EU) with its 28 member states, the post-Soviet Commonwealth of Independent States (CIS) 
with its 11 members, the GUAM (Georgia, Ukraine, Azerbaijan and Moldova) association, an interest group within the CIS which follows a more Western course (Molodikova 2009), the Black Sea Economic Cooperation area set up in 1992 which involves some EU countries (Romania and Bulgaria) as well as post-Soviet countries (Russia, Ukraine, Moldova, Azerbaijan and others) and the Arab Maghreb Union with its five members. Major differences can be identified that distinguish these country groups or regions. The post-Soviet sphere is characterised by a common Russian empire and Soviet history, a common language (Russian), by kinship relations due to Soviet population movements that span the former Soviet Union, and by an integrated transportation system (Molodikova 2009). Nothing similar exists in Western Europe or the Mediterranean region, where no one common language is spoken, except maybe English in Europe and Arabic in the southern and south-eastern rim, and transportation is largely nationally organised. The principle difference, however, between Western Europe and the former communist countries is that the countries in Western and Central Europe are moving towards more integration - with an ever expanding European Union, which involves several post-Soviet (Baltic) countries, whilst the CIS and the Black Sea region is characterised by mixed trends of integration and disintegration (e.g., Zaionchkovskaya 2009). Some countries, notably Russia, Kazakhstan and Belarus are more committed to a common economic and political space whereas Ukraine, Georgia, Moldova, and Azerbaijan are moving towards greater autonomy. On the one hand, the latter countries are historically, economically and culturally linked with Russia, voluntarily or not. On the other hand, they are more western-oriented and tend to be distracted by Russia's omnipotence. Turkey plays a distinctly separate role and is emerging as a regional and even global power, a development fuelled by its economic growth - it is the 17th largest global economy - and political advances. On the one hand it is traditionally attracted by the USA and EU, on the other hand, because of some hesitation on the EU's side, Turkey has begun to develop an alternative to EU membership. Indeed, the country has links with a variety of other regions, as with Russia, Azerbaijan and Turkmenistan, generally in the Balkan, Black Sea and Maghreb regions. Through introducing visa-free entry from many countries and through expanding the Turkish Airline network, some regional integration is being facilitated. Meanwhile, the other Mediterranean countries show little sign of integrating politically or economically. Instead, international relations are often driven by EU policies, such as the EU-inspired Barcelona Process (1995), the Euro-Mediterranean partnership (2004) and the Union for the Mediterranean (2008). These, however, are loosely and sometimes only 
temporarily connected. Meanwhile, the Arab Maghreb Union had already become dysfunctional before the 'Arab Spring'.

With respect to migration, movements of people within most regions are relatively liberal. For instance, within the EU people are almost free and the citizens of most EU countries can live and work indefinitely in another member state, with the exception of some transitory limits for new member states. In the CIS countries the movement of people is also relatively free and no visas are required. Ten countries in Eurasia have established a free-travel zone: most notably, Russia offers visa-free entry to citizens from 10 out of 15 former Soviet republics. Thus, migrants from Moldova who aim to get to Moscow can travel unrestricted through Ukraine, as migrants from Kyrgyzstan can travel through Kazakhstan to Russia. Until 2007, employment and residence of more than three months within the CIS was restricted and required a permit. As a result, labour migration and immigration from one CIS country to another was often irregular. This has since changed; notably Russia made a U-turn and liberalised its migration policy (Molodikova 2009). Migrants can now regularise their residence and employment by a simple registration with the authorities. Turkey, too, has a rather liberal approach to international travel; nationals of Armenia, Azerbaijan, Georgia, Iran, Moldova, Ukraine, Russia, and the Central Asian republics can enter the country quite freely, either with or without visas that can easily be obtained at airports and other entry points (see Apap, Carrera \& Kirişci 2004:19). Also citizens from Morocco or Tunisia are exempted from visa requests in Turkey; others can apply for a visa on the border, as can citizens from Jordan. Only migration around the Maghreb is largely restricted, though visa regimes are not strict. In contrast, travel and migration between regions, notably the CIS, the Black Sea, and the southern and eastern Mediterranean region of the EU are largely restricted. Transit migration through Turkey, Russia and other countries, as, for example, Icduygu and Ivakhnyuk (both this volume) illustrate, is an aspect of the countries' increasing integration into the global system of mobility of people and a consequence of international travel opportunities. Indeed, several chapters suggest tensions between often liberal regional arrangements and rather illiberal inter-regional restrictions that contribute to irregular (transit) movements. In other words, people can travel easily, from, for instance, Algeria to Turkey but not from Turkey to Greece; thus movements from one regional system to the other are restricted and this is one of the crucial conditions that brings about (irregular) transit migration.

From an economic and labour market perspective, the cases of the countries discussed in this chapter differ considerably. Russia and Ukraine, as 
well as Turkey and Egypt, have huge shadow economies which offer many opportunities for irregular labour migrants. Hence, whilst immigration restrictions prevent and complicate regular immigration, there are incentives for migrants who are prepared to engage in the shadow economy. As a result, migrants who aim to move to the EU sometimes find reasons to instead stay in these countries. Kazakhstan and Azerbaijan are oil-producing and thus relatively wealthy countries with plenty of employment opportunities for migrants. By contrast, Ukraine and Turkey are rather middle-income countries with a developed labour market, though they offer different levels of scope for the integration of additional labour migrants. Hence, migrants find some opportunities but they are limited; they may consider a temporary stay but find it hard to settle down permanently. Hungary also is a comparably wealthy country, though hit hard by the crisis and not prepared to integrate international, that is, non-ethnic Hungarian migrants. Therefore, migrants on the way west have little reason to consider staying in this country (see Molodikova, this volume). Morocco is a relatively poor country with fewer earning opportunities for immigrants. Changes to these economic conditions could have an impact on transit migration. For instance, during the 199os, under conditions of economic contraction, Ukraine was mostly a transit country; but for some years during the 2000s, when some sectors were booming, migrants from Africa and Asia began to stay and work or engage in businesses. But if conditions deteriorate again, as under the impact of the economic crisis of 2009, the country may again become mostly a transit country. This shows that the form migration takes is influenced by the economic conditions of the country concerned, though there is not always a link between the two.

Finally, certain hubs can be identified in all countries transited by migrants. Some are staging posts of international migration where migrants en route concentrate, some are entry or exit points, but a few are bottlenecks or even dead-end roads where migrants get stuck. Entry points are, for example, Moscow, Van in Turkey, Oujda on the Algerian-Moroccan border and Al-Khofra in South East Libya on the border with Sudan. Kiev, Odessa and Moscow as well as Istanbul, Rabat and Tripoli are regional hubs; other stage posts, for instance, are Tamanrasset, Agadez and Timbuktu on the road from sub-Saharan countries to the Mediterranean shores. Real bottlenecks between non-EU and EU countries are Zakarpattya in south-western Ukraine, more recently the Serbian border zone with Hungary, Izmir on the Aegean coast of Turkey, and the waters between Libya, Tunisia and Italy. Malta, as Mainwaring (this volume) demonstrates, as well as Cyprus are rather 'dead-end roads', as for some is also Greece. Such bottlenecks also 
exist within the EU, such as the eastern Greek port cities of Patras and Igoumenitsa from where migrants aim to take a ferry to Italy, and Calais, from where migrants aim to reach the UK.

\subsection{Causes, patterns and consequences of transit migration}

Conventionally, transit migration - overland, time-consuming and partly irregular travel through various countries to a certain destination country - is explained with 'porous borders', lax entry controls, liberal visa regulations and the 'geographic position' of 'transit countries' at the crossroads between East and West (e.g., IOM 1995a; Narli 2003). It is also explained with some readily available informal migration industries and with human smuggling and trafficking (Futo, Jandl \& Karsakova 2005). This suggests that the absence of efficient border and internal controls, the existence of criminal networks, and the corruption of authorities almost invites (irregular) transit migration. Further to this, transit migration is commonly linked with the attractions of Western countries, implying that middle-income countries to the east and south of the EU cannot be destinations but only transit countries. Several of these perceptions appear too simplistic, referring either to almost natural, that is, geographical, causes or to rather simplistic social and economic causes and are therefore misleading. The research presented in this volume offers a more sophisticated picture.

Some chapters suggest that certain determinants can be identified that facilitate transit migration or other onward movements. Notably, within the Commonwealth of Independent States (CIS), the heritage of large-scale population movements within the former Soviet Union and an almost unrestricted mobility regime that emerged during the 1990s and 2000s, led to the formation of some national and ethnic diasporas and minorities in every former Soviet Union country. This trend is reinforced by migration traditions dating back to late Soviet times when citizens of 'friendly countries', such as Vietnam, India, Syria or even Cameroon, were recruited through special programmes to the Soviet Union to be educated as teachers, engineers, doctors and military personnel. Thus, ethnic diasporas have emerged, and certain migration networks, traditions and memories have become established that continue to facilitate various forms of migration including transit migration. In the case of Russia, Ivakhnyuk (this volume) argues that existing diasporas, such as the Chinese immigrant community, provide an infrastructure that facilitates migration through Russia 
to Western destinations. Also Mosneaga (ibid.) suggests that Moldovan migration has led to the emergence of a network of stage posts that together act as 'ethnic corridors' for Moldovans wishing to travel overland to more distant destinations. And Molodikova (ibid.) in her analysis of the Hungarian case argues that arrangements aiming to facilitate movements (of ethnic minorities and others) within a small zone along newly established borders, as between Hungary and Serbia, or Ukraine and Poland, are also utilised by transit migrants.

Research has also found that transit migration can be caused by lack of legal and/or economic opportunities in the first or second country of arrival. For instance, in earlier studies it was found that Kurdish refugees in Greece, who after struggling to survive whilst trying to regularise their position or obtaining refugee status finally gave up hope and moved on to the UK (Jordan \& Düvell 2002). Equally, the US Committee for Refugees and Immigrants (2005) relates irregular transit migration through Turkey to the lack of an efficient asylum procedure. Roman (2006: 7) found that refugees from Sudan and Somalia in Egypt were forced to move on to other destinations because of 'lack of local integration prospects'. The same could be said about Turkey: because so far most categories of migrants were refused permission to work (and indeed a proper immigration status) there are few incentives for migrants to stay, which prompts them to search for alternative destinations. Unwelcoming environments, in particular when characterised by additional hostility such discrimination, racism, racial violence and police harassment, as in the case of Africans in Istanbul (see Brewer \& Yükseker 2005) and more recently in Greece, were also found to play a part in preventing migrants from settling down and instead provoked them to move on. In Ukraine, lack of legal status, unfair asylum procedures and unviable economic conditions make it difficult for migrants and refugees to stay (Human Rights Watch 2005). In contrast, Danis, Pérouse and Taragh (2006) find that even under the most adverse conditions, Iraqi, Afghan and Maghrebi migrants in Istanbul who would conventionally be considered as in transit instead managed some 'unofficial integration' and are in fact at least temporary immigrants. Other examples show that even where host societies are largely 'tolerant and hospitable', as it is said to be the case in Azerbaijan (IOM 2003: 11), it was observed that migrants nevertheless move on to other destinations. Hence, neither do adverse conditions inevitably provoke on-migration (or indeed return), nor can it be assumed that favourable conditions prevent on-migration. Thus, the socio-political and economic conditions are not the all-decisive factors in whether or not migrants stay or move on. 
Transit migration can also be explained with the limits in legal migration channels. As it becomes increasingly difficult for certain categories of people to legally migrate to the EU, those who nevertheless wish to come, either as workers, refugees or family members, are driven into complex and hazardous circumventions and paths and face long overland and sea journeys. Empirical evidence suggests that migrants who are prevented from moving to Europe legally and who therefore turn to the services of human smugglers are often taken through a range of countries (e.g., Mavris 2002; Futo, Jandl \& Karsakova 2005). This implies that it is the destination countries' policies that contribute to the emergence and construction of transit migration. Control politics impact on and determine transit migration. Each time controls on a popular route are increased, migrants and smugglers search for other opportunities and finally establish new paths, or new strategies (see Molodikova and Ivakhnyuk, both this volume). As a consequence, flows do not simply diminish but are redirected to other geographical areas. This already became apparent during the mid-199os when it was observed that migrants from distant countries moved south through Romania and Hungary trying to find a loophole into the EU because of increasing controls along the Polish-German borders (FFM 1996). Equally, in the case of the Mediterranean, increased controls in the Straits of Gibraltar between Morocco and Spain first led to migrants leaving from Southern Morocco to go to the Canary Islands; and when controls in South Morocco were improved, migrants departed from Mauretania and even Senegal (German Foreign Policy 2006; De Haas 2007). Finally, when the western Atlantic path - from Morocco and Mauretania - became heavily controlled, notably by concerted FRONTEX controls, the main point of departure to the EU was shifted towards Libya. From 2009, enhanced controls between Libya and Italy resulted in yet another shift of the flow to Turkey and on to Greece, whilst the breakdown of controls due to civil war in Libya again opened up this route. Equally, efforts made in 2012 in enhancing controls on the Turkish-Greek land border led to an increase in migrants departing from the Turkish coast to go to the Greek islands or to instead cross the border into Bulgaria. Similar developments were observed in the case of Georgian migration to Russia: when Russia introduced visas for Georgians in 2002, Georgian migrants began transiting Ukraine and Belarus to exploit the relatively open borders between these countries and Russia. There are hardly any legal opportunities for transit migration; only the UNHCR's resettlement programmes from Egypt, Turkey, Malta and to a much smaller extent in Ukraine offer some limited opportunities (Kaytaz 2006; Al-Sharmani and Mainwaring, both this volume). Neverthe- 
less, sometimes, refugees strategically chose a country, such as Turkey, as they know there is a chance of being resettled legally in a country of their choice thus avoiding clandestine and risky journeys (Kaytaz 2006). Transit migration is a strategic response to the constantly changing control regime and usually increasingly strict immigration legislation. It reflects the complex interaction between migrants' autonomy and states sovereignty and some 'cat and mouse' between the two.

\subsection{Characteristics and strategies of transit migrants}

Issues of social class and gender also play a role in transit migration. Travellers must normally prove that they are bona fide tourists or businessmen. Tourists must convince officers in the visa department of foreign embassies or at the borders of their honest intentions - that they have the means to subsidise themselves and they must demonstrate that they a life to which they will return, hence that they have jobs, a home and families. Equally, labour migrants must meet immigration criteria, such as higher education, high skills and of course job offers. Both categories must then be able to simply book a flight to their final destination. Those who have some funds but are unable to obtain a visa, for example, because they lack the required education or skills or do not otherwise meet the immigration criteria, may instead fly to a country close to their final destination, for example, from Nigeria via Cairo to Russia, and then try to move on. But those with few or no resources, who can only afford the cheapest transportation, need to travel on trains, buses, lorries or even walk through a range of countries toward their intended destination, like from Kabul through Uzbekistan and Russia to Ukraine. Often, however, they can only go as far as their money takes them, and some migrants need to work and earn money in order to finance their next step. Hence, it seems plausible to suggest that the poorer the migrants, the higher the tendency to migrate overland; and the poorer they are, the more likely it is that they stay in countries en route to work, hence the longer they will stay in the transit country and the longer the journey will take.

Brewer and Yükseker (2005:8) found that some individuals only became transit migrants by accident; whilst they were supposed to be taken by smugglers directly to Greece or Italy they were instead taken to and abandoned by human smugglers in Turkey and thus had to continue their journey to the nearest EU country, in this case Greece, on their own account and overland. Mainwaring (this volume) demonstrates that migrants who are on 
their way to Europe may become involuntary transit migrants due to their apprehension. Migrants who take a boat from Libya to Italy have to cross an area that is monitored by Maltese authorities. If they are detected, their boat is taken to Malta where the passengers are detained. They are then kept on the island involuntarily; often they try to move on to Italy and then to other EU countries, or they apply to be resettled in another EU country or the USA, an option only offered to them since 2009. Equally, Mosneaga shows how Moldovans on their way to Italy were unaware that they were taken through Switzerland where they were apprehended. In such cases, transiting Turkey, Switzerland and Malta, respectively, was not intended but forced upon the individuals due to enforcement measures or the betrayal of some informal agents (smugglers). And Alioua (this volume) demonstrates that migrants aiming only to transit a country, such as Morocco, when faced with the progressive closure of EU borders, are forced to settle for a longer time. As a consequence they are compelled to redefine and reorganise their migration project.

Transit migration is sometimes depicted as 'mixed flows' of economic migrants and refugees (for an overview see Düvell 2008). For instance, the origins of transit migration of sub-Saharan Africans through the Maghreb countries towards Europe are varied in terms of location, motives and situations and are particular heterogeneous, as Alioua argues (this volume). On the one hand, reports on transit migration often refer to individuals from conflict countries, notably Iraqis, Iranians, Afghans, Somalis, Eritreans and Palestinians. Accordingly, it may be assumed that many are in search of international protection and may thus be considered refugees. On the other hand, reports equally often refer to Nigerians and Cameroonians, Bangladeshis and Chinese and often it is assumed that these are rather economic migrants who are in search of better opportunities. Sometimes, members of the same family are found in diverse countries. This, as AlSharmani and Ivakhnyuk found in the case of Somalis (this volume; see also Horst 2003) is for two reasons. First, members in one country work and send money home that is then used to enable further family members to also escape Somalia. These then migrate to diverse other countries. This refers to the second reason, which is that through such strategies it is made sure that at least one family member makes it to a safe (European) country; this is thus a kind of risk-diversifying strategy. That these individuals then serve as anchor persons who help others to follow (e.g., through family reunification) seems a plausible assumption.

Some transit movements are straightforward and the individuals seem to know exactly where they want to go. Sometimes, they reach their destination 
within weeks of departure. Others, however, seem to float within a certain region outside the $\mathrm{EU}$ for long periods of time in search of a suitable country or entry point. For instance, in 2008, I interviewed two Palestinian asylum seekers in Debrecen/Hungary; one made the journey in just five weeks 'I was lucky' he admitted the other took two years because he was apprehended and detained, exhausted his money and had to work to acquire new funds for his onward journey. Notably refugees, for instance; Somalis are reported to flee from Somalia and move to Kenya, Djibouti, Ethiopia, Saudi Arabia, Yemen or several of these countries before finally turning up in a country in the neighbourhood of the EU, for example, Turkey, Ukraine or Libya, from where they hope to cross the Mediterranean and Aegean Sea or Carpathian mountains and enter the European Union (e.g., Al-Sharmani, this volume). Usually, migrants from the major sending countries are reported from countries as diverse as Ukraine, Turkey, Egypt and Malta. This suggests that there are many possible paths towards the European Union. It also suggests that from each conflict region there are various paths to safety and that refugees try all of them.

Migrants also change their plans according to the conditions they find and sometimes decide to settle down instead of pursuing their plan to move on. In particular, failed or frustrated transit migrants become almost involuntary or forced immigrants. This results in the emergence or at least expansion and certainly diversification of existing pockets and communities of migrants in the neighbourhood of the EU. These tend to gather in populous suburbs, such as in Rabat, Casablanca or Tangiers and Istanbul or Kiev, Odessa and Moscow; they settle down, some permanently, others temporarily, and superimpose new social relationships and new logics to these locations, as Alioua argues (this volume). From such observations, one may conclude that what began as transit migration sometimes heralds the transition of the migration characteristics of the respective country which turns from a transit to an immigration country. This could be true for Ukraine, certainly for Turkey and to some extent even Morocco.

Some of the conditions analysed above explain why some transit migrants reside in a country en route for considerable periods of time before moving on. In case they must work to fund their onward-journey but can only find low-paid work in the shadow economy, they must stay and work longer to acquire the necessary financial resources. If they are requested to pay higher rents, unduly high fees to officials et cetera, they are again compelled to stay and work longer. If controls are intensified and therefore smugglers ask for higher fees - either to compensate for the higher risks or for bribing more officials - migrants must work longer to save more; 
thus the duration of a transit migrant's stay is prolonged even further. Finally, if migrants are prevented from leaving the transit country and are apprehended and detained - as analysed in the case of Morocco (Collyer 2006) - then the total duration of stay in the transit country has to be longer and migration is de facto slowed down (Panagiotidis \& Tsianos 2007) or even terminated. This might, however, result in unintended side-effects, as transit countries become 'buffer states' or involuntary immigration countries (see below). From the observations presented in this section, it can be concluded that some transit migration is a consequence of certain governments' policies and laws and is socially and politically produced. Other transit migration, however, is by choice and can be considered a self-selected migration strategy.

\subsection{The politics of transit migration}

The migration of citizens from distant countries who cross several other countries before they arrive at the external borders of and finally enter the EU or other European country, often in an irregular manner, has become of increasing concern for all countries affected. This phenomenon was labelled and became popular as 'transit migration'; the individuals are often accordingly called 'transit migrants' and the countries involved are sometimes branded 'transit countries'. From a United Nations (UN) conference, the concept seems to have entered the migration policy discourse during the early 1990 s (UN ECE 1993). Since then, it has become increasingly popular. In 1994, the International Organization for Migration (IOM) urged its member states through a series of papers to recognise transit migration as an important matter in international migration and in particular in irregular and asylum migration (IOM 1994a, b, c, d, e). Widgren (1995), Director of the intergovernmental International Centre for Migration Policy Development (ICMPD, Vienna) at the height of the European asylum panic, warned that most asylum seekers were transiting Central and Eastern European (CEE) countries. In 1998, a strategy paper of the then Austrian presidency of the Council of the European Union emphasised the importance of 'transit migration' and 'transit countries'. This was followed by six action plans on Afghanistan, Sri Lanka, Iraq, Albania, Somalia and Morocco, drafted by the High Level Working Group on Asylum and Migration (HLWG) in 1999. In 2001, the Ministerial Conference of the $5^{+5}$ Dialogue on Migration in the Western Mediterranean (2001) reiterated the necessity of 'joint management of the phenomenon'. Moreover, the United Nations High Commissioner 
for Refugees (UNHCR 2001) alerted national authorities to the emerging phenomenon of transit migration in post-conflict Balkan countries. The Council of Europe (CoE) emphasised that 'perhaps the most salient migration phenomenon currently affecting Central and Eastern Europe is that of transit migrants' (CoE 2002: Part 1). This was followed by a regional conference on 'Migrants in Transit Countries' which raised attention and encouraged national authorities to take appropriate measures ( $\mathrm{CoE} 2004)$. Meanwhile, in 2003, the 'Söderköping Process', a 'cross-border cooperation process' on migration matters, was launched under the auspices of the Swedish government, bringing together the eastern EU countries and its non-EU neighbours. The process targets Ukraine, Belarus and Moldova in order to 'tackle the problems of irregular transit migration and asylum problems' (General Directors' Immigration Service Conference, GDISC 2001). In 2003, ICMPD set up the Mediterranean Transit Migration Dialogue and invited concerned governments to enhance the 'fight against illegal migration' transiting the EU's Mediterranean neighbours (ICMPD 2005). The initiative is concerned with operational matters and intelligence aspects: routes and criminal activities are identified, intelligence exchanged, training provided and technical equipment shared amongst participants. This trend towards intelligence work and engaging in enforcement matters was reinforced by setting up a joint ICMPD/Europol/FRONTEX programme (ICMPD 2006).

Politics to prevent irregular and transit migration, notably the externalisation of surveillance and control policies (see below) and the emergence of 'shadows borders' (see below), increasingly acknowledge and respond to the emergence of spaces (see introduction) and thus go well beyond the conventional Westphalian migration model of sovereign states controlling their national borders. Instead, states or groups of states, that is, the EU, will now operate beyond their territories either through deploying officers in foreign countries or through surveillance in other countries. Thus, the analysis of politics that targets irregular and transit migration reveals a trend towards post-Westphalian migration control, that is, states acting beyond their borders and within entire transit zones and migration spaces, and thus a new era of migration politics.

\section{Expanded control regimes}

European governments and EU agencies have integrated measures targeting transit migration in a range of policies. First, concerns have been associated with those countries which meanwhile became member states (2004: the Baltic republics, Poland, Hungary, Slovakia and the Czech Republic, Slovenia, Malta and Cyprus; 2007: Romania and Bulgaria); second, with present 
candidate countries (Turkey); and third, with its other neighbours (Ukraine, Morocco and Libya). For example, the Romanian government, in order to satisfy EU policy expectations, claimed 'a significant reduction of transit migration from third countries through Romanian territory' (Romanian Ministry of Foreign Affairs 1999). Equally Malta, since it became a full EU member state in 2004, has shielded the mainland and intercepts boat people on their way from Tunisia and Libya to Italy (Mainwaring, this volume). Thus, Malta was assigned the role of a watch tower and gatekeeper of the EU. 'Combating' irregular migration, often of nationals from distant countries who are transiting Mediterranean countries, is at the forefront of the Euro-Mediterranean Partnership (EMP) and the Barcelona process (Lutterbeck 2006: 70). Notably, measures like the FRONTEX (EU border agency) operations Hera and Minerva, which aim to prevent the arrival of 'boat people' on the Canary Islands and the Spanish mainland, reflect this trend. The fact that the migrants who depart from Morocco, Mauritania and even Senegal are often sub-Saharan migrants illustrate that such measures basically target 'transit migrants' aiming to leave the 'transit country'. As a consequence, the control of land and sea borders is increasingly 'militarised' (ibid.: 64). This can be observed in the Mediterranean between Morocco and Spain, Turkey and Greece, Italy and Albania, Libya and Italy and Malta, where armed and naval forces are regularly deployed in border controls. Libya is another country integrated into such policies. In 2006, the EU considered Libya for its European Neighbourhood Programme (ENP) and drafted according action plans to formalise such practices. ENPs (see Guild 2005) aim to improve the EU neighbouring states' capacity to control and restrict migration to, and in particular through, these countries. Negotiations have also been conducted with Moldova, Morocco, Tunisia and Ukraine (Azerbaijan and Georgia are also on the list), to name the migration-relevant countries. For example, the EU-Ukraine Action Plan on Justice and Home Affairs in 2001 and the EU-Ukraine Action Plan of 2004 aim at improvements in such affairs. And in 2009, Italy had reached a bilateral agreement with Libya about joint sea patrols. Whilst the civil war interrupted these, they were resumed in 2012 and fresh collaboration has been established with the new authorities. With Tunisia's new government, similar agreements have been negotiated.

A leading figure of the conservative party in Germany (CDU) states that, 'we must also integrate countries of origin and transit. They must help to contain refugee flows and they must be obliged to readmit their own nationals. There is no other way than putting pressure on these countries. And money' (Bosbach 2006). Apap, Carrera \& Kirişci (2004: 19) confirm that 
countries such as Turkey, 'came under massive pressure from a number of EU member countries to curb ... transit migration'. As a consequence, responsibility for preventing migrants unwanted in the EU from entering its territory has been shifted towards non-EU countries. This process is facilitated through the politics of 'sharing the burden' of protecting global refugees (Thielemann 2003), obligations under bilateral readmission agreements between the EU, individual member states and its non-EU neighbours and in the course of candidate and membership procedures. Sometimes, there is criticism that EU countries simply 'dump' politically unwanted immigrants on their neighbours' territories, for example, through migration containment and return policies, instead of recognising their international obligations towards refugees (Watson 2003). Therefore, some would argue the EU's 'burden sharing' policy is a euphemism for 'shifting the burden' to its neighbouring countries who are held responsible for keeping unwanted immigrants off EU territory and who could therefore become a 'buffer zone' for migrants not wanted in the EU (Kirişci 2006). On the other hand, some non-EU governments also play a 'transit migration' card. Some use it in their negotiation with their neighbours and the $\mathrm{EU}$ as a whole, for example, to divert attention from irregular migration of their own citizens (e.g., see De Haas 2007 on Morocco) or in exchange for improved border controls they negotiate eased visa regulations for their own citizens (as in the case of Ukraine and Moldova).

The transit migration discourse coincides with the EU's introduction of carrier sanctions obliging airlines, bus operators and shipping lines to return illegitimate migrants to their point of departure. Furthermore, efforts have been made by individual member states or the EU as a whole to negotiate readmission agreements with many non-EU neighbours and various sending countries to facilitate return and deportation (Cassarino 2010). For instance, in autumn 2004, the Italian authorities in a dramatic move returned more than one thousand irregular migrants from various African countries back to their point of departure in Libya. This was almost a panic response and was executed in the absence of an adequate policy framework and criticised by a European Parliament committee as 'refoulement', a breach of international obligations, notably the 1951 Geneva Refugee Convention (see Andrijasevic 2006). Similar instances were reported from Ukraine (2008), Greece and again Italy (2009). Also readmission agreements were introduced with countries such as Senegal and Mali that seek to establish collaboration between transit and sending countries. Finally, within the EU the Dublin Convention was agreed, obliging refugees to apply for asylum in the first safe country in which they arrive. Thereby, 
refugees are prevented from travelling through various EU countries to a final destination. For instance, Somali refugees who first enter EU territory in Hungary but move on, for instance, to the Netherlands, will be sent back to Hungary.

In Europe and its vicinity three contrasting trends can be observed. There are countries who fully comply with EU demands to take responsibility for protecting the EU's territory from unwanted migration and collaborate in controlling (irregular) transit migration, such as Moldova, Morocco, Tunisia (with some interruption in 2011) and Libya (from 2009 until the uprising in 2011 and probably again from 2013). Additionally, there are countries that comply at least partially and make some efforts to prevent transit migration, such as Turkey and Ukraine. On the other hand, there are countries that are less enthusiastic and partially or fully reject responsibility in this matter, such as Russia. Some of those who fully comply are already candidate countries to the EU, such as Turkey, and are obliged to implement the various EU policies. Or they accept the EU's idea of 'good neighbourhood relations' and therefore prevent migrants and refugees from moving to the Northern and Western countries. Those who partially or fully implement EU expectations seem to do so because they are hoping for EU candidate status in the future, such as Ukraine and Moldova. However, these hopes already seem to be frustrated and it remains to be seen how these countries respond to this rejection from the EU and whether they will accept EU policies. Compliance with EU expectations, however, does not seem to be without consequences, as several countries complain that they are becoming the 'dumping ground' for migrants and refugees who are unwanted in the EU and in the EU neighbourhood alike (e.g., Lahlou 2009; Malynovska 2009). But whilst some of these countries have become immigration countries, sometimes rather involuntarily, they are often rather unprepared, for example, to cope with rising numbers of refugees, or they are unwilling to regularise labour migration, as in the cases of Ukraine, Turkey and Libya.

A separate trend is that certain countries, not in response to EU pressure but out of genuine national interests, apply the concept of 'transit migrants' to specific groups of migrants, often people who require some kind of protection, for instance, because they come from conflict countries. This signals that these groups of migrants are not accepted as immigrants but are almost expected to leave again at some point, for example, to either return or, more controversially to move on to other countries. The message is that the host countries reject any long-term responsibility. Such practice has been observed in Ukraine and Egypt, but also Turkey insists that refugees are rather 'guests'. Thus, the discursive use of the concept of 
transit migration sometimes also implies either some problems with the respective country's interpretation of the international refugee conventions or some views that conflict with those held by EU countries.

The plethora of initiatives and the many actors engaged in 'combating' transit and other unwanted migration demonstrates that this has become a top policy aim. The policy goals are perfectly illustrated by an IOM document $(1995 \mathrm{~b}$ : 48,47$)$ stating that transit countries shall either 'pay attention to specific needs ... of refugees' and thereby prevent them from being prompted to move on; or they shall 'return them ... to their country of origin'. In other words, transit migration policies aim to identify and intercept potential transit migrants, prevent them from moving on to Western Europe, and either enable them to stay in their transit country, for example by improving asylum procedures, or return them to their country of origin.

\section{The shadow borders of the EU}

Conventional maps show the territorial borders of the European Union in conjunction with the borders of its peripheral member states: Finland, Lithuania, Poland, Slovakia, Hungary, Romania, Bulgaria, Greece, Cyprus, Slovenia, Italy, Malta and Spain. However, various EU migration control posts and operations are found well outside these territorial borders. For instance, the EU or individual member states fund detention camps in Lutsk/Ukraine, in Nouadhibou/Mauritania and in Libya; EU immigration and police officers are deployed in Kiev and Ankara in order to prevent unwanted migrants and refugees from getting anywhere near EU borders; and in Libya the EU funded the return of migrants to sub-Saharan countries through the IOM's 'voluntary' return programme. The EU is also investing in the establishment of asylum seekers' reception centres and processing procedures, for example, in Ukraine and Turkey. The aim is to turn nonEU countries into safe countries, so that refugees can be expected to file their claim in these countries and if they do not do this and move on to the EU, they might even be sent back to that country if apprehended. In various countries, governments have agreed to comply with EU demands to contain migration movements towards the EU. It would seem as if the EU is establishing another unofficial border - a migration control border, well outside its territorial border. It is neither internationally agreed or delineated nor properly regulated. Instead it is a second or shadow border which runs through Nouadhibou in Mauritania, 1,20o kilometres from EU territory (Canaries/Spain) and 2,00o kilometres from mainland Spain; through Kiev 
in Ukraine, 600 kilometres away from Poland; and through Van in Turkey, around 1,90o kilometres from the nearest EU country (Greece).

\section{Increasing risks and emerging protection gaps}

Would-be migrants and refugees respond to the various migration and border control regimes described in this volume in three ways. They either abandon their aspirations and do not migrate, or they travel or migrate where it is legally possible, or they travel and migrate in an irregular fashion. In the latter case enhanced controls, notably the closing of previous routes, usually compel travellers to take alternative routes; often these turn out to be more dangerous, like routes through desserts, across the seas or across mountains. Thus, enhanced controls indirectly increase the risks for travellers (see Weber \& Pickering 2011). A good example of this is the closing of the land route in Thrace between Turkey and Greece in 2012, which pushed those who were nevertheless desperate to migrate to the EU to the more dangerous Aegean Sea route. Several maritime accidents usually reported by Turkish sources illustrate these risks. But also the absence of legal migration channels, which drives people into engaging with smugglers, increases the risks. This is because this type of arrangement is by its very nature unregulated and only based on trust, money and power; it can thus easily be exploited by the smuggler and there are some who do this. As a result those who are willing to travel clandestinely might either be betrayed for their money, subjected to violence or sexual abuse or sent on a journey where they risk or even lose their lives (see Khosravi 2010; Triandafyllidou \& Maroukis 2012). Also certain reports highlight incidences in the no man's lands between two countries or on the open seas, referring to refugee boats rammed by coast guard boats or pushed back to where they were coming from (Amnesty International 2013). All these cases point to severe crimes as well as violations of refugee and human rights against migrants and refugees whilst travelling. Normally, they should be protected by national and international law in the countries on either side of their journey, the countries they leave and the countries they aim to enter, but they seem to be left unprotected whilst in-between these countries. This gives rise to a severe protection gap, and the international community needs to respond to this development.

\section{Consensual versus conflicting migration diplomacies}

Often, it has been the EU that communicates its concerns to countries that are transited by migrants and refugees in order to convince these countries to contribute to containing such movements. In exchange, the EU offers 
funds, technology and training but also visa or trade liberalisation. This mechanism could be observed in the EU's Eastern Partnership Programme with, for instance, Ukraine. Meanwhile, countries in the neighbourhood of the EU have also discovered the power of the transit migration argument and turned this into a card in their negations or arguments with the EU. For instance, in spring 2011, whilst the EU was pressing hard to get the Turkish government into an agreement over readmission - on the return of irregular immigrants in the EU that had transited Turkey - Turkey demanded that in return the EU lift the visa restrictions for Turkish nationals. Subsequently, this failed and neither did the EU get its readmission agreement ratified nor was Turkey granted any significant visa liberalisation. Also in spring 2011 Libya's dictator Gaddafi threatened to unleash a wave of illegal migration to the EU if the EU continued to support the liberation movement. And indeed, soon afterwards, as it was claimed, agents of the regime were pushing migrants into north-bound boats. Thus, third-country nationals residing in Libya were turned into an argument and subsequently a weapon against the EU. A few weeks later, however, the Transitional National Council of Libya reassured the EU that they would comply with all previous agreements regarding Libya's commitment to control and contain migration across its territory and from its shores to the North. In this case, it was the rebels using the migration card to demonstrate that they would be reliable partners to the EU. In any case, transit migration has not only become an issue for diplomacy but indeed a ball to play with.

\subsection{Countries transited by migrants: Similar and different}

In spite of the diversity of migration flows, the causes of transit migration and types of transit countries, there are striking similarities between the very distant cases of Ukraine, Turkey, Morocco and Malta. All are described as cross-roads between East and West, and South and North respectively, and all are positioned in the borderland of the EU (between poor and sending and rich and receiving regions). They are also situated on traditional trading routes between the South and East and the North and West. In many migrant-sending countries, there are vague memories of the routes through these countries and of the hospitality which traders and travellers encountered in the past. This is sometimes reinforced by earlier positive memories of citizens of migrant-sending countries who were educated at, for instance, a Ukraine or Russian university or military academy, or those who spent some time legally working in Libya, for example. Thus, when 
the need arises to leave a country which is suffering from war or poverty, these memories seem to influence migration decisions and determine the paths taken and the countries transited. Such memories, however, can be treacherous and difficulties become apparent as soon as transit turns out to be less easy than assumed and when a longer than intended stay becomes necessary.

Another similarity is that Turkey, Egypt and Ukraine have experienced large-scale emigration; meanwhile, they have also become receiving countries. Simultaneously, all face considerable pressure from the EU to keep unwanted migration away from the EU's external borders, as well as to host refugees and process their claims for asylum. Some authors argue that these and other countries have become 'reservoirs' for migrants unwanted in the EU (e.g., Ivakhnyuk, this volume). Few are well prepared to receive or properly deal with and integrate large numbers of refugees and/ or labour migrants and offer no or insufficient reception facilities for newly arrived migrants. Notably the asylum reception and processing structures are underdeveloped and are overwhelmed by the influx of refugees. The situation in the detention facilities of Chop (Ukraine), Edirne (Turkey) and Hal Far (Malta) seems similarly dire.

Migrants and refugees gather and mix in similar locations in most countries. These are usually found in the poorer neighbourhoods of the capital and other large cities (Istanbul/Tarlabasi and Laleli, Izmir/Basmane, Tripoli/Medina, Cairo/Nasr City and Rabat/Sale and Side Musa). In Istanbul, Izmir or Tripoli these neighbourhoods are located in the inner cities; in Moscow, however, they concentrate on the south-eastern outskirts (Vendina 2002) and in Kiev, migrants are concentrated in Troieshchyna. In most cities, they occupy run-down and usually overcrowded apartments, whereas in Moscow and Izmir they live in hotels and hostels. Paradoxically they often pay even higher rents than the local poor, as their precarious status is exploited by unscrupulous landlords. In some cities, notably in Morocco, there seems to be no place for transit and other migrants; instead, they are compelled to live in makeshift settlements outside the cities, as in Missnana Forest/Tangier, in Gourougou outside Melilla or in the Bel Younech woods outside of Ceuta.

In most countries transited by migrants - and not only in these - discourses can be found that portray migrants and refugees as a (security) threat, as taking jobs and other resources from the indigenous populations, as being involved in crime, and even transmitting diseases, even though there is little evidence for this (Lahlou 2009; Kaya 2009; Pylynskiy 2008). Related discursive threads are that (a) countries lack resources to host 
migrants and refugees (Malta, Morocco and Egypt) or (b) that governments do not consider refugees a permanent immigrant population but a passing occurrence, assuming that refugees will either move on, return, or be resettled to other countries (Russia, Ukraine and Turkey). The widely-held belief that migrants and refugees are only in transit also serves as an excuse so that governments do not need to introduce integration or refugee reception schemes.

In any case, in most countries in the neighbourhood of the EU no efforts are made to integrate migrants and refugees: instead this is prevented. For instance, access to employment is restricted, either by impractical requirements as in Ukraine and Egypt, or it is legally ruled out, as in Turkey. And if migrants wish to work they have to do so irregularly. Egypt even puts a social reservation on its refugee law which excludes refugees from almost all public services, including health and education. Often they are victims of heavy-handed police operations, as in Morocco (Smith 2006), or daily harassment, as in Turkey and Ukraine, and racial violence, as in Russia and Ukraine. These practices are without doubt contributing to the migrants' and refugees' feelings of fear and uncertainty and demonstrate on a daily basis that they are not welcome but should instead leave.

\subsection{Conclusion}

There are five main effects of the controls on the journeys of migrants. One is that migrants get stuck or stranded in the countries they only aim to transit. As a consequence, migrants become involuntary immigrants and the respective countries turn into places of involuntary immigration. Another effect is that in response to new or improved controls, migrants and smugglers develop new paths, routes and means of entry. The third effect is that migration is slowed down and that journeys take longer. The fourth effect is that the number of those who manage to navigate controls and subsequently arrive in the destination country or region, notably the EU, is reduced. And the fifth effect is that a protection gap emerges, meaning that irregular migrants, whilst in the hands of smugglers or in the no man's land between two sovereign countries, have no law or authority to protect them. The consequence is that the migration patterns, the geographies as well as the scope of transit migration are constantly changing whilst often the risks associated with the journeys are increasing (Weber \& Pickering 2011).

By examining where migrants live and work and how they travel, it is not easy if at all possible to distinguish them as labour migrants or refu- 
gees, temporary immigrants or transit migrants, and regular or irregular migrants. Instead, the different types of migrants often mix with each other; they live in the same neighbourhoods, share the same apartments, do the same jobs, travel in the same coaches or boats and lose, gain or switch immigration statuses. Indeed, they also inform and inspire each other. Thus, migrants' motives, legal statuses and flows are more often mixed than not.

Usually the criteria applied to define transit migration are (a) intentions to enter and cross a certain country in order to arrive at another country, (b) to do so in a limited period of time, and (c) not to integrate and thus temporarily immigrate to this country. All of these criteria, however, are problematic. Intentions are subject to change, either in response to experiences and information obtained whilst en route or due to structural constraints, whether due to lack of funding or to control politics. Time is another problematic criterion and set time limits inevitably appear arbitrary. Transit in the common understanding is a matter of hours or days and immigration is commonly defined as a stay of more than one year. Hence, two types of migration, temporary immigration and transit migration, fall into the same duration and are thus difficult to distinguish by the duration of the stay in a country en route. What remains is the issue of the quality of the activities undertaken during the time spent in the given country, notably whether or not a person integrates with the social and economic structures. This, however, is difficult to measure and the threshold for what qualifies as integration is problematic to set.

The migrants considered in this volume, that is, migrants who cannot simply obtain a visa and a flight ticket and who therefore engage in long overland and maritime journeys, often change their migration project and flexibly adapt to constraints and opportunities, as well as to information received from others. Therefore, individuals cannot simply be categorised as one type of migrant or another. Accordingly, the various forms of migration - immigration, circular and other temporary migration, and transit migration - do not represent clearly separate types of migration but overlap, turn from one form into the other and are rather temporary expressions of dynamic and continuous human mobility.

Finally, the concept of transit migration is so highly loaded with politics that it has become problematic to use. Even though various contributions in this volume demonstrate that there are forms of migration that could be labelled transit, though these are less frequent and numerically smaller than commonly assumed, any such label would not only be a scientific label but a political label; it would not simply be the most appropriate technical term for a social phenomenon but a subject of political arguments. Thus, the 
scientific value of the term has been severely undermined by its political use.

Several contributions in this book have shown that often those who are considered transit migrants are not; instead they are (temporary) immigrants or, in case people move on after a longer stay in a country en route, this must rather be considered on- or secondary migration; that some of those who are not considered transit migrants, such as foreign students, instead might consider themselves merely being in transit or that transit may not be an accurate but rather a misleading label, for instance, if migrants are de facto 'stranded'. Other contributions, conversely, demonstrated that certain migrants actually intend to and succeed in transiting certain countries within or outside the EU within short periods of time, days, weeks or a few months, and without interacting much with the structures and systems of the countries they transit, that is, without working or learning the language. Still, these seem to be fewer in number than commonly assumed. What remains, however, is the tension between how migrants perceive themselves, what type of identity they have, like certain types of foreign students in Russia, who present themselves as in transit, so they might be mentally in transit and thus not integrate, whilst de facto they would be categorised as temporary immigrants. Thus, in the end it is the researchers who have to consider both aspects and their impact on the individual case studied and make a plausible judgement they can defend.

The analyses presented in this volume imply that the labels 'transit migration', 'transit migrants' and 'transit countries' are applied far too often and unthinkingly. Instead, certain dynamic and continuous migration processes are far too complex to be captured by just one label; the contributions in this book rather illustrate that often the type of migrants considered are problematic to categorise. Even more so, the study of transitory migrations questions efforts to categorise migrants according to their motives, intentions and time spent in certain countries because time thresholds are problematic and ultimately arbitrary to set whilst motives and intentions are subject to change. Thus, it is suggested to categorise flows and individuals separately.

Therefore, it seems plausible and possible to identify certain forms of human mobility as 'transit migration', notably if these are observed retrospectively and thus as an observable fact that migrants have transited a certain country (c) on their way from country (a) to country (b). But it seems much more difficult to also label the individuals involved as 'transit migrants'. Instead, through rigid comparison more fine-tuning is required: often those who are considered transit migrants are but involuntary immigrants (who 
intended to only transit but got stuck), frustrated immigrants (who intended to stay and work but were frustrated and thus moved on) or on-migrants, a phenomenon sometimes also labelled secondary migration (migrants who intended to stay and work in a certain country for some period of time but developed an intention to move on to other countries). What remains an issue, however, and subsequently undermines any attempt to categorise certain groups of migrants, is that often the individuals considered in this book are highly flexible and adaptable to the constraints and opportunities found, that their aspirations and intentions are highly dynamic and change due to the information received and the experiences had so that initial decisions are changed or made en route and that as a consequence their trajectories are also flexible, dynamic and unpredictable.

\section{References}

Amnesty International (2013), Greece: Frontier Europe. Human Rights Abuses on Greece's Border with Turkey. London: Amnesty International.

Andrijasevic, R. (2006), Lampedusa in Focus: Migrants Caught between Libyan Dessert and the Deep Sea. Brussels: Policy Documentation Centre.

Apap, J., S. Carrera \& K. Kirişci (2004), 'Turkey in the European Area of Freedom, Security and Justice'. EU-Turkey Working Paper No. 3. Brussels: Centre for European Policy Studies.

Bosbach, W. (2006), 'Löchrige Festung', Interview, Rheinischer Merkur, www.rheinischer-merkur. de/index.php?id=13310, accessed 15 June 2006.

Brewer, K. \& D. Yükseder (2005), 'The unending migration process: Survival strategies of African migrants in Istanbul. "Waiting” to leave for Europe'. Paper submitted to IMILCO workshop, Istanbul, 1-2 December.

Cassarino, J.-P. (2010), Readmission Policy in the European Union, Brussels: Directorate General for Internal Policies, Policy Department C: Citizens' Rights and Constitutional Affairs, Civil Liberties, Justice and Home Affairs, European Parliament.

Cassarino, J.-P. \& P. Fargues (2006), 'Policy responses in MENA countries of transit for migrants: An analytical framework for policymaking', in N.N. Sørensen (ed.), Mediterranean Transit Migration. Copenhagen: Danish Institute for International Studies, 101-108.

Collyer, M. (2006), 'States of Insecurity: Consequences of Saharan Transit Migration'. Working Paper 31. Oxford: Centre for Migration, Policy and Society.

Council of Europe (CoE) (2002), Towards a Migration Management Strategy. Strasbourg: Committee on Migration, Council of Europe European.

Council of Europe (CoE) (2004), 'Final communiqué'. Regional Conference 'Migrants in the Transit Countries: Sharing Responsibilities in Management and Protection', Council of Europe, 3 o September-1 October, Istanbul.

Danis, D., J.F. Pérouse \& C. Taragh (2006), Integration in Limbo, Iraqi, Afghan and Maghrebi Migrants in Istanbul. Research Report. Istanbul: Koc University, available at www.ifeaistanbul.net/oui/ouiprogr.htm.

De Haas, H. (2007), 'The Myth of Invasion: Irregular Migration from West Africa to the Maghreb and the European Union', IMI Research Report. Oxford: International Migration Institute. 
Düvell, F. (2006a), Illegal immigration in Europe. Houndmills: Palgrave/MacMillan.

Düvell, F. (2006b), 'Crossing the fringes of Europe: Transit migration in the EU's neighbourhood'. Working Paper No. 33. Oxford: Centre for Migration, Policy and Society.

Düvell, F. (2008), 'Migrants and refugees on the fringes of Europe: Transit migration, mixed flows and new policy challenges', Metropolis World Bulletin 8: 29-32.

Düvell, F. (2009), Paths into Irregularity. Athens: ELIAMEP.

Düvell, F. \& I. Molodikova (2009), 'Introduction', in I. Molodikova \& F. Düvell (eds), Transit Migration and Transit Countries: Theory, Practice and Policy of Regulation. Moscow: University Press, 9-31.

Düvell, F. \& B. Vollmer (2009), Irregular Migration in and from the Neighbourhood of the EU: A Comparison of Morocco, Turkey and Ukraine. Comparative Transit Country Report. Athens: Eliamep, http://clandestino.eliamep.gr/wp-content/uploads/2009/11/transit_report_compas_septog1.pdf.

Düvell, F. \& B. Vollmer (2011), Improving EU and US Migration Systems: European Security Challenges. Florence: European University Institute.

Forschungsgesellschaft Flucht und Migration (FFM) (1996), Rumänien: Vor den Toren der Festung Europa. Berlin: Verlag der Buchläden.

Futo, P., M. Jandl \& L. Karsakova (2005), 'Illegal migration and human smuggling in Central and Eastern Europe', Migracijske i etničke teme 21 (1-2): 35-54.

General Directors' Immigration Services Conference (GDISC) (2001), 'Söderköping Process'. http://soderkoping.org.ua.

German Foreign Policy (20o6), Eins zu zehn. 13 March, www.german-foreign-policy.com/de/ fulltext/5680, accessed 15 March 2006.

Guild, E. (2005), What Is a Neighbour? Examining the EUNeighbourhood Policy from the Perspective of Movements of People. London: Liberty and Security, www.libertysecurity.org/article270. html, accessed 14 June 2006.

Horst, C. (2003), Transnational Nomads: How Somalis Cope with Refugee Life in the Daddab Camps of Kenya. Doctorate dissertation. Amsterdam: Amsterdam University.

Human Rights Watch (2005), Ukraine: On the margins. Rights violations against migrants and asylum seekers at the new eastern border of the European Union. Washington: Human Rights Watch.

ICMPD (2005), What is the MTM Dialogue? Vienna: ICMPD.

ICMPD (2006), First preparatory meeting for joint ICMPD-EUROPOL-FRONTEX Project 'Towards a Comprehensive Response to Mixed Migration Flows', Vienna: ICMPD, www.icmpd.org/846. html?\&tx_icmpd_pi2[document] $=470 \&$ cHash=441004cbo1.

International Organization for Migration (IOM) (2003), Study on Transit Migration through Azerbaijan. Baku: IOM.

International Organization for Migration (IOM) (1995a), Transit Migration in Turkey. Geneva: IOM.

International Organization for Migration (IOM) (1995b), Irregular Migration in Central Europe: The Case of Afghan Asylum Seekers in Hungary. Geneva: IOM.

International Organization for Migration (IOM) (1994a), Transit Migration in Hungary. Geneva: IOM.

International Organization for Migration (IOM) (1994b), Transit Migration in Bulgaria. Geneva: IOM.

International Organization for Migration (IOM) (1994c), Transit Migration in the Czech Republic. Geneva: IOM.

International Organization for Migration (IOM) (1994d), Transit Migration in Poland. Geneva: IOM. 
International Organization for Migration (IOM) (1994e), Transit Migration in the Russian Federation. Geneva: IOM.

Jordan, B. \& F. Düvell (2002), Irregular Migration: Dilemmas of Transnational Mobility. Cheltenham: Edward Elgar.

Kaya, I. (2009), Undocumented Migration, Counting the Uncountable, Country Report: Turkey. Athens: ELIAMEP.

Kaytaz, E. (2006), 'Turkey as a country of Transit Migration'. MPhil thesis. Oxford: Oxford University.

Kirişci, K. (2006), 'The Hague programme: Challenges of Turkish pre-accession in the area of asylum, migration and border control', in J.W. de Zwaan \& F.A. Goudappel (eds), Freedom, Security and Justice in the European Union. The Hague: Asser Press, 164-171.

Khosravi, S. (2010), 'Illegal traveller': An Auto-Ethnography of Borders. Basingstoke: Palgrave Macmillan.

Lahlou, M.(2009), Undocumented Migration, Counting the Uncountable, Country Report: Morocco. Athens: ELIAMEP.

Lutterbeck, D. (2006), 'Policing migration in the Mediterranean', Mediterranean Politics 11 (1): 59-82.

Malynovska, O. (2009), 'Transitnaia nelehalnaia migratsia: Ukrainia', in I. Molodikova, \& F. Düvell (eds), Transit Migration and Transit Countries: Theory, Practice and Policy of Regulation. Moscow: University Press, 130-159.

Mavris, L. (2002), 'Human smugglers and social networks: Transit migration through the states of former Yugoslavia'. Evaluation and Policy Analysis Unit, Refugee Research Working Paper No. 72. Geneva: UNHCR.

Molodikova I. (2009), 'Patterns of east west migration in the context of European migration systems: Possibilities and limits of migration', Demográfia , 51(5) (English Edition): 5-35.

Moscow News (2009), 'Russia hosts up to 4 million illegal immigrants', 2 April, www.mosnews. com/world/2009/04/02/migraioninrussia/

Narli, N. (2003), 'Human smuggling and migration of illegal labor to Turkey', in P. Jurekoviæ \& F. Labarre (eds), Crushing Crime in South-East Europe: A Struggle of Domestic, Regional and European Dimensions. Vienna: National Defence Academy and Bureau for Security Policy, 61-88.

Panagiotidis, E. \& V. Tsianos (2007), 'Denaturalizing “camps”: Überwachen und Entschleunigen in der Schengener Ägäis-Zone', in S. Hess \& V. Tsianos (eds), Turbulente Ränder: Neue Perspektiven auf Migration an den Grenzen Europas. Bielefeld: Transcript, 57-85.

Papadopoulou, A. (2005), 'Exploring the asylum-migration nexus: A case study of transit migrants in Europe'. Global Migration Perspectives No. 23. Geneva: Global Commission on International Migration.

Pylynskyi, Y. (2008), Undocumented Migration, Counting the Uncountable, Country Report: Ukraine. Athens: ELIAMEP.

Roman, H. (2006), 'Transit migration in Egypt'. CARIM Research Report. Florence: European University Institute.

Romanian Ministry of Foreign Affairs (1999), EU Integration Process: Measures to Strengthen Border Control and Curb Illegal Migration. Sofia, http://domino.kappa.ro/mae/dosare.nsf/.

Smith, A. (2006), 'The immigrants' last resort', Sunday Times Magazine, 19 March, also see www. onesizeup.com/onesizeup-portfolio/_msf_site/morocco/morocco-4.htm.

Thielemann, E. (2003), 'Editorial introduction', Journal of Refugee Studies 16 (3): 225-235.

Triandafyllidou, A. \& T. Maroukis (2012), Migrant Smuggling:Irregular Migration from Asia and Africa to Europe. Basingstoke: Palgrave Macmillan. 
UNECE (1993), International Migration Bulletin, No 3. Geneva: United Nations Economic Commission for Europe.

UNHCR (2001), The Interface between Migration and Asylum in Bosnia and Herzegovina. UNHCR: Sarajevo.

US Committee for Refugees and Immigrants (2005), Turkey: Country Report 2005. Washington: USCRI.

Vendina, O. (2002), 'Social polarization and ethnic segregation in Moscow', Eurasian Geography and Economics 43 (3): 216-243.

Vogel, D. (2009), 'Size of irregular migration'. Policy Brief. Athens: ELIAMEP.

Watson, R. (2003), 'Britain wins guarded support for establishing asylum camps outside Europe', The Times, 4 June.

Weber, L. \& S. Pickering (2011), Globalization and Borders: Death at the Global Frontier. Basingstoke: Palgrave MacMillan.

Widgren, J. (1995), Towards Collective European Cooperation with Respect to the Movements of People. Vienna: ICMPD.

Zaionchkovskaya, Z. (2009), 'Transitnaia migratsia w stranash CNG', in I. Molodikova \& F. Düvell (eds), Transit Migration and Transit Countries: Theory, Practice and Policy of Regulation. Moscow: University Press, 68-97. 


\section{Abbreviations}

\begin{tabular}{|c|c|}
\hline AVR & Assisted Voluntary Return \\
\hline BBC & British Broadcasting Corporation \\
\hline CCTV & Close Circuit Television \\
\hline CEE & Central and Eastern Europe \\
\hline CHALLENGE & The Changing Landscape of European Liberty and Security \\
\hline CIS & Commonwealth of Independent States \\
\hline $\mathrm{CoE}$ & Council of Europe \\
\hline COMPAS & Centre on Migration Policy and Society \\
\hline CPT & Committee on the Prevention of Torture \\
\hline CWL & Care with Love \\
\hline DFHF & Department for Fighting Human Trafficking \\
\hline EaP & Eastern Partnership \\
\hline EC & European Commission \\
\hline ECE & Economic Commission for Europe \\
\hline ECRE & European Council on Refugees and Exiles \\
\hline EMP & Euro-Mediterranean Partnership \\
\hline ENI & European Neighbourhood Initiative \\
\hline ENP & European Neighbourhood Policy \\
\hline EU & European Union \\
\hline EUBAM & EU Border Assistance Mission \\
\hline EURASEC & Eurasian Economic Community \\
\hline FFM & Forschungsgesellschaft Flucht und Migration \\
\hline FMS & Federal Migration Service (Russia) \\
\hline FSB & Federal Security Service (Russia) \\
\hline FYU & Former Yugoslavia \\
\hline GDISC & General Directors' Immigration Services Conference \\
\hline GUAM & Union of Georgia, Ukraine, Azerbaijan and Moldova \\
\hline HHC & Hungarian Helsinki Committee \\
\hline HLWG & High Level Working Group on Asylum and Migration \\
\hline HRW & Human Rights Watch \\
\hline ICMPD & International Centre for Migration Policy Development \\
\hline IMI & International Migration Institute \\
\hline \multirow[t]{2}{*}{ IMISCOE } & International Migration, Integration and Social Cohesion (European \\
\hline & Research Network) \\
\hline ILO & International Labour Organization \\
\hline IOM & International Organization for Migration \\
\hline JRS & Jesuit Refugee Services \\
\hline
\end{tabular}


KHS

MEP

MFA

MFSS

MIPEX

MJHA

MoE

MP

MSF

NBM

NGO

NIS

NMS

OIN

ROSSTAT

RSD

SAR

SIS

UK

UN

UNDP

UNHCR

UNICEF

USA

USSR
Központi Statisztikai Hivatal - Népességtudományi Kutatóintézet

(Hungarian Central Statistical Office - Demographical Institute)

Member of European Parliament

Ministry of Foreign Affairs

Ministry for Family and Social Solidarity

Migration Integration Policy Index

Ministry for Justice and Home Affairs

Ministry of Education and Culture

Member of Parliament

Médecins Sans Frontièrs

National Bank of Moldova

Non-Governmental Organisation

Newly Independent States

new member states

Office of Immigration and Nationality

National Statistics Committee of the Russian Federation

Refugee Status Determination

Search and Rescue

Schengen Information System

United Kingdom

United Nations

United Nations Development Programme

United Nations High Commissioner for Refugees

United Nations International Children's Emergency Fund

United States of America

Union of the Socialist Soviet Republics 


\section{Author information}

Mehdi Alioua is enseignant-chercheur in the Department of Political Science at the International University of Rabat. He is also an associate researcher with the Centre Jacques Berque in Rabat. His research concerns the movement of sub-Saharan migrants into and through North Africa with a particular focus on the analysis of cross-border social networks. Mehdi completed his PhD in sociology at the University of Toulouse 2 (Le Mirail) in 2011.

Mulki Al-Sharmani is an Academy of Finland Research Fellow and Lecturer, Faculty of Theology, Study of Religion Unit, at the University of Helsinki. Mulki received her doctorate degree in cultural anthropology in 2005 from the Johns Hopkins University, Baltimore, USA. From 2005 to 2010, she was a joint research/teaching faculty at the American University in Cairo. From 2010 to 2011, she was a research fellow at Helsinki Collegium for Advanced Studies, University of Helsinki. Mulki's research interests and work are in transnational migratory family life, gender and migration, Islamic family laws in Muslim-majority countries and in Western countries and Muslim feminist engagement with Islamic textual tradition.

Michael Collyer is a Senior Lecturer in Geography at the University of Sussex. His research concerns the relationship between mobile people and state institutions. He has held visiting positions at universities in Morocco, Egypt, Sri Lanka and the USA. He is associate editor of the Journal of Ethnic and Migration Studies and sits on a number of editorial boards, including that of Géographie et Développement au Maroc.

Franck Düvell is a Social Scientist, Senior Researcher and Associate Professor at the Centre for Migration, Policy and Society (COMPAS) University of Oxford. Previously, he was contract senior researcher at the International Centre for Migration Policy Development (ICMPD), Jean Monnet Fellow at Robert-Schuman Centre for Advanced Studies, European University Institute (Florence), Research Fellow at the University of Exeter and lecturer in sociology, political science and geography at Bremen University, Germany. He is also a member of IMISCOE, the executive committee of PICUM and convener of the Turkish Migration Studies Group. His research focuses on European and international migration, specifically, irregular and mixed migration, borders and on European and international migration politics. 
His recent projects concentrate on transit migration in Ukraine and Turkey and migration aspirations in various sending countries. He has published several books, including Irregular Migration (2002) and Illegal Migration: Beyond Control? (2006), as well as articles in the Journal for Ethnic and Migration Studies; Population, Space and Place; European Journal for Migration and Law; Social Science Information; Journal for Critical Social Policy; and Open Democracy.

Hein de Haas is Co-director of the International Migration Institute (IMI) at the University of Oxford. Hein de Haas's research focuses on the linkages between migration and broader processes of human development and globalisation, primarily from the perspective of migrant-sending societies. He did extensive fieldwork in the Middle East and North Africa and, particularly, Morocco. He has published on a wide range of issues including migration theory, migration and development, remittances and transnationalism, integration, migration determinants, migration futures and the links between migration and environmental change. Hein de Haas is also Honorary Professor in Migration and Development at Maastricht University.

Ahmet İçduygu is Professor of International Relations and Director of the Migration Research Program (MiReKoc) at Koç University, Istanbul, Turkey. He holds a PhD from the Australian National University (1991). He served as Associate Professor and Associate Chairperson of the Department of Political Science, Bilkent University. He was Research Fellow at Stockholm University (1991-1992), Visiting Fellow at the University of Warwick (1998-200o), Research Fellow and Visiting Professor at the University of Manchester (1999-200o), and Visiting Fellow at the European University Institute in Florence (2010-2011). His current research and teaching interests are international migration, Mediterranean studies, civil society and citizenship, ethnicity and nationalism. In addition to articles in journals such as International Migration, International Social Science Journal, Global Governance, Middle Eastern Studies, Ethnic and Racial Studies, Population and Environment, Human Rights Quarterly, Citizenship Studies and Population, Space, and Place, Prof. İçduygu has two recent books, Migration and Transformation:Multi-LevelAnalysis of Migrant Transnationalism (co-edited in 2012 with Pitkänen and Sert) and Countries of Migrants, Cities of Migrants (co-edited in 2013 with Balbo and Serrano). 
Irina Ivakhnyuk is Professor and Deputy-Director of the Population Department at the Faculty of Economics, Lomonosov Moscow State University. She is a demography graduate of Moscow State Lomonosov University and was awarded her doctoral degree in population economics at the Russian Academy of Sciences in 1981. In 2008 she successfully defended her post-doctoral population economics degree, with a focus on the Eurasian migration system, and is now a doctor of science and full professor. Her professional interest is the migration of populations, in particular, the causes, consequences and management of international migration; migration and development; and migration policies. She participated in a number of international research projects on international migration and is author of numerous publications.

Cetta Mainwaring is an Assistant Professor in Sociology at the University of Waterloo, Canada. She completed her DPhil in international relations at the University of Oxford in 2012, where she was affiliated with the Centre on Migration, Policy and Society. Her research is broadly interested in how and why people move across national borders, especially without state authorisation, and how states respond to various forms of international mobility in attempts to deter, facilitate or shape such flows. Her doctoral research examined irregular immigration into Southern Europe, analysing the relationship between the EU and small member states (Malta and Cyprus) in order to understand how these relationships shape and are shaped by migration flows. Her current research project explores the historical evolution of visa policies in the USA and UK. She has published articles in the Journal for Ethnic and Migration Studies; Population, Space and Place; and Refugee Survey Quarterly.

Irina Molodikova, from Moscow State University (Russia) and Master of Advanced Studies from the European University Center for Peace Studies (Austria), is head of the Migration and Security Programme of the CENSE Centre at Central European University, Budapest, member of the IMISCOE network and the Research Council CIS countries on migration. She is supervisor of the North Caucasus Initiative of the Open Society Foundation, editor and author of numerous articles and books on migration issues and on the situation in the Caucasus region. Her textbook Thirty-Five Class Hours (2012) for teachers of schools in multicultural environments was adopted as a manual for all institutes of teachers training in the North Caucasus republics. 
Valeriu Mosneaga is Professor and Head of the Department of Political Science, Faculty of International Relations, Political and Administrative Sciences, Moldova State University. His research focuses on post-Soviet migration, specifically, labour and irregular migration, emigration/immigration in/from the Republic of Moldova and on the migration politics of Moldova. He has published several books and more than $5^{0}$ articles on these issues.

Deniz Sert is Assistant Professor of International Relations at Özyeğin University. She obtained her BA from Koç University, Department of International Relations, in 2000, her MSc in European Studies from the London School of Economics in 2001 and her PhD in Political Science from City University of New York in 2008. After completing her PhD, Sert joined the Migration Research Center at Koç University (MiReKoc) where she conducted research in different projects on international migration. Her areas of expertise are conflict, forced migration, international migration, irregular migration, transnationalism, border management and civil society. 


\section{Other IMISCOE Research titles}

Michael Bommes, Heinz Fassmann and Wiebke Sievers (eds)

Migration from the Middle East and North Africa to Europe: Past

Developments, Current Status and Future Potentials

2014 ISBN 9789089646507

Masja van Meeteren

Irregular Migrants in Belgium and the Netherlands: Aspirations and Incorporation

2014 ISBN 9789089646439

Yolande Jansen

Secularism, Assimilation and the Crisis of Multiculturalism: French

Modernist Legacies

2013 ISBN 9789089645968

Marlou Schrover and Deidre M. Moloney (eds)

Gender, Migration and Categorisation: Making Distinctions between

Migrants in Western Countries, 1945-2010

2013 ISBN 9789089645739

Birgit Glorius, Izabela Grabowska-Lusinska and Aimee Kuvik (eds)

Mobility in Transition: Migration Patterns after EU Enlargement

2013 ISBN 9789089643926

Joan Font and Mónica Méndez (eds)

Surveying Ethnic Minorities and Immigrant Populations: Methodological

Challenges and Research Strategies

2013 ISBN 9789089645432

Marek Okólski (ed.)

European Immigrations: Trends, Structures and Policy Implications 2012 ISBN 9789089644572

Ulbe Bosma (ed.)

Post-Colonial Immigrants and Identity Formations in the Netherlands 2012 ISBN 9789089644541 
Christina Boswell and Gianni D'Amato (eds)

Immigration and Social Systems: Collected Essays of Michael Bommes

2012 ISBN 9789089644534

Maurice Crul, Jens Schneider and Frans Lelie (eds)

The European Second Generation Compared:Does the Integration Context Matter?

2012 ISBN 9789089644435

Bram Lancee

Immigrant Performance in the Labour Market: Bonding and Bridging

Social Capital

2012 ISBN 9789089643575

Julie Vullnetari

Albania on the Move: Links between Internal and International Migration 2012 ISBN 9789089643551

Blanca Garcés-Mascareñas

State Regulation of Labour Migration in Malaysia and Spain:Markets,

Citizenship and Rights

2012 ISBN 9789089642868

Albert Kraler, Eleonore Kofman, Martin Kohli and Camille Schmoll (eds) Gender, Generations and the Family in International Migration 2012 ISBN 9789089642851

Giovanna Zincone, Rinus Penninx and Maren Borkert (eds)

Migration Policymaking in Europe: The Dynamics of Actors and Contexts in Past and Present 2011 ISBN 9789089643704

Michael Bommes and Giuseppe Sciortino (eds)

Foggy Social Structures: Irregular Migration, European Labour Markets and the Welfare State

2011 ISBN 9789089643414 
Peter Scholten

framing immigrant integration: dutch research-policy dialogues in comparative Perspective

2011 ISBN 9789089642844

Liza Mügge

Beyond Dutch Borders: Transnational Politics among Colonial Migrants, Guest Workers and the Second Generation

2010 ISBN 9789089642448

Rainer Bauböck and Thomas Faist (eds)

Diaspora and Transnationalism: Concepts, Theories and Methods 2010 ISBN 9789089642387

Cédric Audebert and Mohamed Kamel Dorai (eds)

Migration in a Globalised World: New Research Issues and Prospects 2010 ISBN 9789089641571

Richard Black, Godfried Engbersen, Marek Okólski and Cristina Pantîru (eds)

A Continent Moving West? EU Enlargement and Labour Migration from

Central and Eastern Europe

2010 ISBN 9789089641564

Charles Westin, José Bastos, Janine Dahinden and Pedro Góis (eds)

Identity Processes and Dynamics in Multi-Ethnic Europe

2010 ISBN 9789089640468

Rainer Bauböck, Bernhard Perchinig and Wiebke Sievers (eds)

Citizenship Policies in the New Europe: Expanded and Updated Edition

2009 ISBN 9789089641083

Gianluca P. Parolin

Citizenship in the Arab World: Kin, Religion and Nation-State 2009 ISBN 9789089640451

Maurice Crul and Liesbeth Heering (eds)

The Position of the Turkish and Moroccan Second Generation in Amsterdam and Rotterdam: The TIES Study in the Netherlands 2008 ISBN 9789089640611 
Marlou Schrover, Joanne van der Leun, Leo Lucassen and Chris Quispel (eds)

Illegal Migration and Gender in a Global and Historical Perspective 2008 ISBN 9789089640475

Corrado Bonifazi, Marek Okólski, Jeannette Schoorl and Patrick Simon (eds)

International Migration in Europe: New Trends and New Methods of Analysis

2008 ISBN 9789053568941

Ralph Grillo (ed.)

The Family in Question: Immigrant and Ethnic Minorities in Multicultural Europe

2008 ISBN 9789053568699

Holger Kolb and Henrik Egbert (eds)

Migrants and Markets: Perspectives from Economics and the Other Social Sciences

2008 ISBN 9789053566848

Veit Bader

Secularism or Democracy? Associational Governance of Religious Diversity 2007 ISBN 9789053569993

Rainer Bauböck, Bernhard Perchinig and Wiebke Sievers (eds)

Citizenship Policies in the New Europe

2007 ISBN 9789053569221

Rainer Bauböck, Eva Ersbøll, Kees Groenendijk and Harald Waldrauch (eds)

Acquisition and Loss of Nationality: Policies and Trends in 15 European

Countries

Volume 1: Comparative Analyses

2006 ISBN 9789053569207

Volume 2: Country Analyses

2006 ISBN 9789053569214 
Leo Lucassen, David Feldman and Jochen Oltmer (eds)

Paths of Integration: Migrants in Western Europe (1880-2004)

2006 ISBN 9789053568835

Rinus Penninx, Maria Berger and Karen Kraal (eds)

The Dynamics of International Migration and Settlement in Europe: A State of the Art

2006 ISBN 9789053568668

\section{IMISCOE Textbooks}

Marco Martiniello and Jan Rath (eds)

An Introduction to Immigrant Incorporation Studies: European

Perspectives (Vol.3)

2014 ISBN 9789089646484

Marco Martiniello and Jan Rath (eds)

An Introduction to International Migration Studies: European Perspectives (Vol. 2)

2012 ISBN 9789089644565

Marco Martiniello and Jan Rath (eds)

Selected Studies in International Migration and Immigrant Incorporation (Vol. 1)

2010 ISBN 9789089641601 
